\title{
Antigen-specific active immunotherapy for ovarian cancer (Review)
}

Paijens ST, Leffers N, Daemen T, Helfrich W, Boezen HM, Cohlen BJ, Melief CJM, de Bruyn M, Nijman HW

Paijens ST, Leffers N, Daemen T, Helfrich W, Boezen HM, Cohlen BJ, Melief CJM, de Bruyn M, Nijman HW.

Antigen-specific active immunotherapy for ovarian cancer.

Cochrane Database of Systematic Reviews 2018, Issue 9. Art. No.: CD007287.

DOI: 10.1002/14651858.CD007287.pub4.

www.cochranelibrary.com 
TABLE OF CONTENTS

ABSTRACT 1

PLAIN LANGUAGE SUMMARY

SUMMARY OF FINDINGS

BACKGROUND

OBJECTIVES

METHODS

RESULTS

Figure 1.

DISCUSSION

AUTHORS' CONCLUSIONS

ACKNOWLEDGEMENTS

REFERENCES

CHARACTERISTICS OF STUDIES

ADDITIONAL TABLES

APPENDICES

WHAT'S NEW

HISTORY

CONTRIBUTIONS OF AUTHORS

DECLARATIONS OF INTEREST

SOURCES OF SUPPORT

ST

DIFFERENCES BETWEEN PROTOCOL AND REVIEW

INDEX TERMS 
[Intervention Review]

\section{Antigen-specific active immunotherapy for ovarian cancer}

Sterre T Paijens ${ }^{1}$, Ninke Leffers ${ }^{1}$, Toos Daemen², Wijnand Helfrich ${ }^{3}$, H Marike Boezen ${ }^{4}$, Ben J Cohlen ${ }^{5}$, Cornelis JM Melief6, Marco de Bruyn1, Hans W Nijman²

1Obstetrics \& Gynaecology, University Medical Center Groningen (UMCG), Groningen, Netherlands. 2University Medical Center Groningen (UMCG), Groningen, Netherlands. ${ }^{3}$ Department of Surgery. Translational Surgical Oncology, University Medical Center Groningen (UMCG), Groningen, Netherlands. 4 Unit Chronic Airway Diseases, Department of Epidemiology, University Medical Center Groningen (UMCG), Groningen, Netherlands. ${ }^{5}$ Department of Obstetrics \& Gynaecology, Isala Clinics, Location Sophia, Zwolle, Netherlands. 6Department of Immunohaematology and Blood Transfusion, Leiden University Medical Center, Leiden, Netherlands

Contact: Sterre T Paijens, Obstetrics \& Gynaecology, University Medical Center Groningen (UMCG), Groningen, 9713 GZ, Netherlands. s.t.paijens@umcg.nl.

Editorial group: Cochrane Gynaecological, Neuro-oncology and Orphan Cancer Group.

Publication status and date: New search for studies and content updated (no change to conclusions), published in Issue 9, 2018.

Citation: Paijens ST, Leffers N, Daemen T, Helfrich W, Boezen HM, Cohlen BJ, Melief CJM, de Bruyn M, Nijman HW. Antigen-specific active immunotherapy for ovarian cancer. Cochrane Database of Systematic Reviews 2018, Issue 9. Art. No.: CD007287. DOI: 10.1002/14651858.CD007287.pub4.

Copyright ( 2018 The Cochrane Collaboration. Published by John Wiley \& Sons, Ltd.

\section{A B S T R A C T}

\section{Background}

This is the second update of the review first published in the Cochrane Library (2010, Issue 2) and later updated (2014, Issue 9).

Despite advances in chemotherapy, the prognosis of ovarian cancer remains poor. Antigen-specific active immunotherapy aims to induce tumour antigen-specific anti-tumour immune responses as an alternative treatment for ovarian cancer.

\section{Objectives}

\section{Primary objective}

- To assess the clinical efficacy of antigen-specific active immunotherapy for the treatment of ovarian cancer as evaluated by tumour response measured by Response Evaluation Criteria In Solid Tumors (RECIST) and/or cancer antigen (CA)-125 levels, response to postimmunotherapy treatment, and survival differences

- In addition, we recorded the numbers of observed antigen-specific humoral and cellular responses

Secondary objective

- To establish which combinations of immunotherapeutic strategies with tumour antigens provide the best immunological and clinical results

\section{Search methods}

For the previous version of this review, we performed a systematic search of the Cochrane Central Register of Controlled Trials (CENTRAL; 2009, Issue 3), in the Cochrane Library, the Cochrane Gynaecological Cancer Group Specialised Register, MEDLINE and Embase databases, and clinicaltrials.gov (1966 to July 2009). We also conducted handsearches of the proceedings of relevant annual meetings (1996 to July 2009).

For the first update of this review, we extended the searches to October 2013, and for this update, we extended the searches to July 2017. 


\section{Selection criteria}

We searched for randomised controlled trials (RCTs), as well as non-randomised studies (NRSs), that included participants with epithelial ovarian cancer, irrespective of disease stage, who were treated with antigen-specific active immunotherapy, irrespective of type of vaccine, antigen used, adjuvant used, route of vaccination, treatment schedule, and reported clinical or immunological outcomes.

\section{Data collection and analysis}

Two reviews authors independently extracted the data. We evaluated the risk of bias for RCTs according to standard methodological procedures expected by Cochrane, and for NRSs by using a selection of quality domains deemed best applicable to the NRS.

\section{Main results}

We included 67 studies (representing 3632 women with epithelial ovarian cancer). The most striking observations of this review address the lack of uniformity in conduct and reporting of early-phase immunotherapy studies. Response definitions show substantial variation between trials, which makes comparison of trial results unreliable. Information on adverse events is frequently limited. Furthermore, reports of both RCTs and NRSs frequently lack the relevant information necessary for risk of bias assessment. Therefore, we cannot rule out serious biases in most of the included trials. However, selection, attrition, and selective reporting biases are likely to have affected the studies included in this review. GRADE ratings were high only for survival; for other primary outcomes, GRADE ratings were very low.

The largest body of evidence is currently available for CA-125-targeted antibody therapy (17 studies, 2347 participants; very low-certainty evidence). Non-randomised studies of CA-125-targeted antibody therapy suggest improved survival among humoral and/or cellular responders, with only moderate adverse events. However, four large randomised placebo-controlled trials did not show any clinical benefit, despite induction of immune responses in approximately $60 \%$ of participants. Time to relapse with CA-125 monoclonal antibody versus placebo, respectively, ranged from 10.3 to 18.9 months versus 10.3 to 13 months (six RCTs, 1882 participants; high-certainty evidence). Only one RCT provided data on overall survival, reporting rates of $80 \%$ in both treatment and placebo groups (three RCTs, 1062 participants; high-certainty evidence). Other small studies targeting many different tumour antigens have presented promising immunological results. As these strategies have not yet been tested in RCTs, no reliable inferences about clinical efficacy can be made. Given the promising immunological results and the limited side effects and toxicity reported, exploration of clinical efficacy in large welldesigned RCTs may be worthwhile.

\section{Authors' conclusions}

We conclude that despite promising immunological responses, no clinically effective antigen-specific active immunotherapy is yet available for ovarian cancer. Results should be interpreted cautiously, as review authors found a significant dearth of relevant information for assessment of risk of bias in both RCTs and NRSs.

\section{PLAIN LANGUAGE SUMMARY}

\section{Antigen-specific active immunotherapy for ovarian cancer}

\section{Background}

Ovarian cancer is the leading cause of death from gynaecological cancers. Standard therapy consists of surgery and chemotherapy. Responses to chemotherapy are generally good; however, most women experience relapse, for which no curative treatment is available. The presence of certain immune cells in tumours is associated with longer survival. This suggests that stimulation of anti-tumour immune responses (i.e. immunotherapy) might be a useful approach for improving outcomes among women with ovarian cancer.

\section{Review question}

This review evaluated the feasibility of antigen-specific active immunotherapy. Antigen-specific active immunotherapy aims to induce anti-tumour immune responses through administration of a tumour antigen - a molecule that is expressed by tumour cells and is hardly expressed by healthy cells. Reviewers collected information on clinical outcomes, immunological responses, and side effects.

\section{Main findings}

We identified 67 studies, which included 3632 women with ovarian cancer and were published between 1966 and 2017 . The most frequently described strategy was administration of antibodies targeting the tumour antigen CA-125 (2347 participants in 17 studies). Most of these studies primarily evaluated safety and immunological responses. Severe flu-like and gastrointestinal symptoms occurred in $7 \%$ to $30 \%$ of participants. Researchers frequently detected antibodies and immune cells recognising the tumour antigen CA-125, albeit response rates varied between studies. Despite these promising immunological responses, four large studies reported no survival advantage for participants treated with CA-125-directed antibody over those given placebo.

For strategies not relying on antibody administration, similar conclusions cannot yet be drawn. Overall, study authors report that treatment was well tolerated and inflammatory side effects at the injection site were most frequently observed. Researchers observed responses of the immune system for most strategies studied, but the clinical benefit of these strategies remains to be evaluated in large trials.

\section{Certainty of the evidence and conclusions}


Because no high-certainty evidence of clinical benefit is currently available, antibody therapy targeting CA-125 should not be incorporated into standard treatment in its current form.

Based on lack of uniformity in included studies, we strongly advocate universal adoption of response definitions, guidelines for adverse events reporting, and directives for trial conduct and reporting. Furthermore, results from ongoing randomised controlled trials (RCTs) are awaited, and further RCTs should be conducted. 
SUMMARY OF FINDINGS

\section{Summary of findings for the main comparison. Antigen-specific immunotherapy for ovarian carcinoma}

\section{Antigen-specific immunotherapy for ovarian carcinoma}

Patient or population: ovarian carcinoma

Setting: primary and recurrent ovarian carcinoma

Intervention: antigen-specific immunotherapy

\begin{tabular}{|c|c|c|c|}
\hline Outcomes & Impact & $\begin{array}{l}\text { № of participants } \\
\text { (studies) }\end{array}$ & $\begin{array}{l}\text { Certainty of the } \\
\text { evidence } \\
\text { (GRADE) }\end{array}$ \\
\hline $\begin{array}{l}\text { Tumour response } \\
\text { assessed with: } \\
\text { RECIST }\end{array}$ & $\begin{array}{l}\text { In total, } 2 \text { participants }(0.01 \%) \text { were defined as having a com- } \\
\text { plete response, } 9(0.03 \%) \text { had a partial response, and } 50(14 \%) \\
\text { had stable disease. Twelve participants }(0.03 \%) \text { showed no ev- } \\
\text { idence of disease. Finally, } 218(61 \%) \text { participants had progres- } \\
\text { sive disease. The remaining } 64(18 \%) \text { participants were not } \\
\text { mentioned. }\end{array}$ & $\begin{array}{l}355 \\
\text { (17 observational } \\
\text { studies) }\end{array}$ & $\begin{array}{l}\oplus \odot \odot \odot \\
\text { Very lowa,b,c,d }\end{array}$ \\
\hline $\begin{array}{l}\text { Tumour response } \\
\text { assessed with: } \\
\text { CA- } 125 \text { according to } \\
\text { GCIG criteria }\end{array}$ & $\begin{array}{l}\text { In total, } 8 \text { participants (13\%) were reported to have an increase } \\
\text { in CA-125. In } 22 \text { patients, CA-125 was stable or decreasing } \\
(34 \%) \text {. The remaining } 34 \text { participants }(53 \%) \text { were considered } \\
\text { not evaluable or were not mentioned. }\end{array}$ & $\begin{array}{l}64 \\
\text { ( } 6 \text { observational } \\
\text { studies) }\end{array}$ & $\begin{array}{l}\oplus \odot \odot \odot \\
\text { Very lowa,b,c,d,e }\end{array}$ \\
\hline $\begin{array}{l}\text { Post-immunother- } \\
\text { apy treatment re- } \\
\text { sponse } \\
\text { assessed with: sur- } \\
\text { vival }\end{array}$ & $\begin{array}{l}\text { Two studies suggested that antigen-specific immunotherapy } \\
\text { may lead to improved responses to future therapy. Two studies } \\
\text { revealed no evidence of a difference. }\end{array}$ & $\begin{array}{l}88 \\
\text { ( } 4 \text { observational } \\
\text { studies) }\end{array}$ & $\begin{array}{l}\oplus \odot \odot \odot \\
\text { Very lowa,f }\end{array}$ \\
\hline $\begin{array}{l}\text { Survival } \\
\text { assessed with: } \\
\text { overall survival }\end{array}$ & $\begin{array}{l}\text { None of the } 3 \text { RCTs estimating overall survival found a signifi- } \\
\text { cant difference in overall survival. Two studies of CA- } 125 \text { mon- } \\
\text { oclonal antibody vs placebo evaluated overall survival, respec- } \\
\text { tively, at } 57.5 \text { vs } 48.6 \text { months ( } 95 \% \text { Cl } 041 \text { to } 1.25 \text { ) and } 80 \% \text { sur- } \\
\text { vival for both groups. }\end{array}$ & $\begin{array}{l}1062 \\
\text { (3 RCTs) }\end{array}$ & $\begin{array}{l}\oplus \oplus \oplus \oplus \\
\text { High }\end{array}$ \\
\hline $\begin{array}{l}\text { Survival } \\
\text { assessed with: pro- } \\
\text { gression-free sur- } \\
\text { vival/time to re- } \\
\text { lapse }\end{array}$ & $\begin{array}{l}\text { None of the } 6 \text { RCTs found statistically significant differences in } \\
\text { progression-free survival/time to relapse, including } 4 \text { RCTs eval- } \\
\text { uating CA- } 125 \text { monoclonal antibody vs placebo; time to relapse } \\
\text { ranged from } 10.3 \text { to } 18.9 \text { months vs } 10.3 \text { to } 13 \text { months, respec- } \\
\text { tively. }\end{array}$ & $\begin{array}{l}1882 \\
\text { (6 RCTs) }\end{array}$ & $\begin{array}{l}\oplus \oplus \oplus \oplus \\
\text { High }\end{array}$ \\
\hline $\begin{array}{l}\text { Antigen-specific im- } \\
\text { munogenicity (hu- } \\
\text { moral response) } \\
\text { assessed with: } \\
\text { ELISA/Luminex as- } \\
\text { say }\end{array}$ & $\begin{array}{l}\text { Nine studies evaluated anti-idiotopic (Ab2) humoral response, } \\
\text { with responses ranging from } 3 \% \text { to } 100 \% \text {. Ten studies evaluat- } \\
\text { ed anti-anti-idiotropic (Ab3) humoral response, with responses } \\
\text { ranging from } 0 \% \text { to } 100 \% \text {. Two studies observed no humoral re- } \\
\text { sponse to other antigen-specific immunotherapy, and the } 9 \text { re- } \\
\text { maining studies noted large differences in percentages of par- } \\
\text { ticipants with measurable antigen-specific antibodies (IgG: } 8 \% \\
\text { to } 96 \% \text { ). }\end{array}$ & $\begin{array}{l}1521 \\
\text { ( } 25 \text { observational } \\
\text { studies) }\end{array}$ & $\begin{array}{l}\oplus \odot \Theta \odot \\
\text { Very lowa,d,g }\end{array}$ \\
\hline $\begin{array}{l}\text { Antigen-specific im- } \\
\text { munogenicity (cel- } \\
\text { lular response) } \\
\text { assessed with: } \\
\text { e.g. IFN- } ү \text { ELISPOT/ } \\
\text { proliferation as- }\end{array}$ & $\begin{array}{l}\text { A total of } 39 \text { studies showed an induced cellular immune re- } \\
\text { sponse in at least } 1 \text { cohort and to at least } 1 \text { target antigen; } \\
\text { range of positive response varied broadly between } 18 \% \text { and } \\
100 \% \text {. One study retrospectively compared cellular immune re- } \\
\text { sponse after CA-125 monoclonal antibody treatment vs place- }\end{array}$ & $\begin{array}{l}966 \\
\text { (40 observational } \\
\text { studies) }\end{array}$ & $\begin{array}{l}\oplus \odot \odot \odot \\
\text { Very lowa,d,g,h }\end{array}$ \\
\hline
\end{tabular}




\section{say/IFN- $\gamma$ secretion bo but showed no significant differences (31.8\% intervention vs assay $26.3 \%$ control).}

Ab2: anti-idiotopic; Ab3: anti-anti-idiotopic; CA: cancer antigen; Cl: confidence interval; ELISA: enzyme-linked immunosorbent assay; GCIG: Gynecologic Cancer Intergroup; IFN: interferon; RCTs: randomised controlled trials; RECIST: Response Evaluation Criteria In Solid Tumors.

GRADE Working Group grades of evidence.

High certainty: we are very confident that the true effect lies close to that of the estimate of the effect.

Moderate certainty: we are moderately confident in the effect estimate: the true effect is likely to be close to the estimate of the effect, but there is a possibility that it is substantially different.

Low certainty: our confidence in the effect estimate is limited: the true effect may be substantially different from the estimate of the effect.

Very low certainty: we have very little confidence in the effect estimate: the true effect is likely to be substantially different from the estimate of effect.

a Most studies were uncontrolled phase $\mathrm{I} / \mathrm{II}$ trials.

bA large percentage of the included participants were not mentioned or were not evaluable for the analysis.

cExplicit descriptions of tumour responses per participant and the time points at which evaluations took place frequently were not available.

dDisease status at start of treatment differed among studies. Therefore the likelihood of clinical and immune responses to immunotherapy, especially in uncontrolled studies, which frequently include participants with recurrent disease and previous exposure to different types of therapy, is likely to be affected.

eCA-125 is a biomarker that serves as an indication for response; however CA-125 does not directly reflect tumour size.

fAlthough in one study participants with a complete response had strong humoral responses, similar or stronger antibody responses were observed for participants with stable or progressive disease.

gBetween studies, there were broad differences in (1) response definition, (2) number of treatment cycles after which immune responses were measured, and (3) targeted antigens.

hExplicit descriptions of immune responses per participant and the time points at which evaluations took place, types of evaluations, and when an evaluation was considered positive often were not available. 


\section{B A C K G R O U N D}

\section{Description of the condition}

Ovarian cancer is the sixth most common cancer and the seventh most common cause of death from cancer among women worldwide (Torre 2012). It is the second most common gynaecological cancer and the leading cause of death from gynaecological cancers in the Western world. As most ovarian malignancies $(80 \%$ to $90 \%)$ arise from the epithelium, all statements about ovarian cancer presented in the remainder of this review apply to epithelial ovarian cancer only. Worldwide age-standardised incidence rates range from 5 per 100,000 in less developed areas to 9.1 per 100,000 in developed areas (Torre 2012).

Stage of disease at presentation is the most important prognostic factor. Owing to the asymptomatic course of the disease, most participants have extensive disease at presentation (stage III to IV, according to the International Federation of Gynecology and Obstetrics (FIGO) classification (Prat 2015)). Despite standard treatment, which consists of cytoreductive surgery and platinumbased chemotherapy, almost all women with advanced-stage disease at presentation will experience relapse, with median progression-free survival of only 18 months. When residual or recurrent disease manifests itself, resistance to chemotherapy often prohibits further curative therapy, resulting in disease-specific fiveyear survival for women with advanced-stage ovarian disease of only $10 \%$ to $20 \%$ (Agarwal 2006; Thigpen 2000).

\section{Description of the intervention}

The immune system seems to play a role in ovarian cancer. This is reflected in the observation that in more than half of women with ovarian cancer, T-cells are present within tumour islets (Raspollini 2005; Zhang 2003). Women with advanced ovarian cancer, whose tumour is infiltrated by these T-cells, have better clinical outcomes than women without these tumour-infiltrating T-cells (Dong 2006; Raspollini 2005; Zhang 2003). More specifically, higher numbers of cytotoxic T-cells, which can directly recognise and kill tumour cells, and increased ratios between cytotoxic T-cells (CD8+) and helper T-cells (CD4+) within the tumour epithelium are associated with improved survival (Gooden 2011; Sato 2005).

Immunotherapy is one of the novel therapeutic strategies under investigation for ovarian cancer. It aims to induce or enhance active immune responses directed towards the tumour and to consolidate anti-tumour effects of standard therapy, delaying and possibly preventing disease progression. Antigen-specific active immunotherapy aims to activate the adaptive immune system directed towards a specific target antigen through administration of a molecularly defined antigen-specific vaccine to the patient.

\section{How the intervention might work}

An antigen is a molecule - usually a protein or a polysaccharide - that can stimulate an immune response. Tumour antigens can be subdivided into different categories such as mutated self-proteins, products of oncogenes (e.g. Her-2/Neu), mutated tumour suppressor genes (e.g. p53), and aberrantly expressed self-proteins (e.g. sperm protein 17, MAGE-1). Numerous tumourassociated antigens are known in ovarian cancer. To obtain a tumour-specific immune response, immunotherapy exploits the differential expression of antigens between normal and tumour cells. A major challenge related to the safety of immunotherapy lies in the prevention of autoimmunity (i.e. induction of immune cells that preferentially recognise and kill tumour cells while avoiding destruction of normal body cells). From a theoretical point of view, other possible side effects include allergic reactions to components of the vaccine and inflammatory reactions at the site of injection.

\section{Why it is important to do this review}

Researchers are now employing several immunotherapeutic strategies by using different tumour antigens. However, this research generally has not yet evolved past phase I/II studies. To our knowledge, no systematic review of antigen-specific active immunotherapy in ovarian cancer has been carried out so far.

This review evaluates the immunogenicity and clinical efficacy of antigen-specific active immunotherapy in ovarian cancer. A systematic review about this topic should prove useful for ascertaining the effectiveness of this treatment modality for ovarian cancer.

\section{O B J E C T IVES}

\section{Primary objective}

- To assess the clinical efficacy of antigen-specific active immunotherapy for the treatment of ovarian cancer as evaluated by tumour response measured by Response Evaluation Criteria In Solid Tumors (RECIST) and/or cancer antigen (CA)-125 levels, response to post-immunotherapy treatment, and survival differences

- In addition, we recorded the numbers of observed antigenspecific humoral and cellular responses

\section{Secondary objective}

- To establish which combinations of immunotherapeutic strategies with tumour antigens provide the best immunological and clinical results

\section{METHODS}

\section{Criteria for considering studies for this review \\ Types of studies}

We had anticipated that we would identify limited randomised controlled trials (RCTs) on this topic. Therefore, we included phase I and phase II non-randomised studies (NRSs) and phase III RCTs. We realise that results from NRSs cannot readily be extrapolated to the general population, but given the lack of RCTs, inclusion of these studies in the review was justifiable.

\section{Types of participants}

We included women with a diagnosis of epithelial ovarian cancer, irrespective of stage of disease. However, as patient populations may differ substantially between different types of studies to be included in this review, we documented what type of participant was included in each study (e.g. women with end-stage disease, women with residual disease).

Because we anticipated that we would find few studies that included women with ovarian cancer only, we also included immunotherapeutic studies in people with cancer that included at least two women with ovarian cancer, with the additional requirement that the results for these individual women were 
separately identifiable from those of the study publication or could be obtained by communication with the study author, and we extracted only data on these women for inclusion in the review. We are fully aware of the vigilance necessary when conclusions are based on studies with such small numbers, but we believe that given the anticipated lack of large RCTs, inclusion of these studies in this review is justifiable.

\section{Types of interventions}

Antigen-specific active immunotherapy is defined as therapy that aims to induce an adaptive immune response directed towards the tumour through administration of a specific well-defined tumour antigen. We compared interventions against each other based on the above-mentioned characteristics.

We included all interventions that aimed to provide antigenspecific active immunotherapy, irrespective of type of vaccine, antigen, or adjuvant used; route of vaccination; and vaccination schedule.

\section{Types of outcome measures}

\section{Primary outcomes}

\section{Clinical efficacy}

To assess clinical efficacy, we evaluated the following.

- Tumour responses to immunotherapy (complete/partial response, stable/progressive disease), as measured by:

- cancer antigen (CA)-125 levels according to or transposable to Gynecologic Cancer Intergroup (GCIG) criteria (Rustin 2004); or

- tumour response according to World Health Organization (WHO) criteria - WHO 1979 - or Response Evaluation Criteria in Solid Tumors (RECIST) criteria - Therasse 2000.

- We evaluated responses to post-immunotherapy treatment, as evidence suggests that people with small cell lung cancer treated with chemotherapy after immunotherapy have improved survival as opposed to people who do not receive immunotherapy (Antonia 2006).

- We assessed:

- survival differences, including time to relapse or progressionfree survival, based on treatment with immunotherapy.

\section{Antigen-specific immunogenicity}

We recorded the numbers of observed antigen-specific humoral and cellular responses. When possible, we separately reported responses of cytotoxic (CD8+) T-lymphocytes and/or helper (CD4+) T-lymphocytes.

\section{Secondary outcomes}

\section{Carrier-specific immunogenicity}

Given that certain immunotherapeutic strategies rely on the use of carriers that may be the target of an immune response besides the intended antigen-specific immune response, we recorded information on the induction of carrier-specific immune responses when appropriate.

\section{Adverse events}

To obtain information on the toxicity of antigen-specific immunotherapy, we extracted data on adverse events observed and reported in the different studies. We categorised adverse events as local adverse events at the site of immunisation and systemic adverse events (all other reported adverse events). We subdivided systemic adverse events into autoimmunity, allergic reactions, and other adverse events occurring after immunisation. If sufficient information was available, we classified adverse events according to the National Cancer Institute Common Terminology Criteria for Adverse Events (NCI CTCAE) (CTCAE 2009).

\section{Search methods for identification of studies}

\section{Electronic searches}

For the original review (Leffers 2010), we searched the Cochrane Central Register of Controlled Trials (CENTRAL; 2013, Issue 9), in the Cochrane Library (Appendix 1), along with the Cochrane Gynaecological Cancer Group Specialised Register, in October 2013. We also searched MEDLINE (1966 to July 2009) and Embase (1974 to July 2009) according to the search strategies listed (Appendix 2; Appendix 3, respectively).

For the first update of the review, we extended the searches to October 2013, and for this update, we extended the searches to July 2017:

- Cochrane Central Register of Controlled Trials (CENTRAL; 2017, Issue 6), in The Cochrane Library;

- MEDLINE via OVID (October 2013 to June week 4 2017);

- Embase via OVID (October 2013 to 2017 week 27).

\section{Searching other resources}

We also searched the prospective trial register at www.clinicaltrials.gov.

We undertook handsearching of abstracts in the proceedings of annual meetings of the Society of Gynecologic Oncologists, the American Association for Cancer Research, and the International Society for Biological Therapy of Cancer (1996 to July 2009). The International Society for Biological Therapy of Cancer has been renamed the Society for Immunotherapy of Cancer (SITC), thus we also searched the proceedings of the annual meeting of SITC.

We checked the bibliography of each primary reference and of recent reviews on immunotherapy for ovarian cancer for additional study publications. In addition, we wrote to specialists involved in research regarding immunotherapy for ovarian cancer to ask for information about the results of unpublished and ongoing studies. We included relevant data in this review.

\section{Data collection and analysis}

\section{Selection of studies}

We downloaded to Reference Manager all titles and abstracts retrieved by electronic searching. We applied no language restrictions other than those inherent to the databases surveyed. We removed duplicates, and two review authors (HWN and NL) independently examined the remaining references. We excluded studies that clearly did not meet the review inclusion criteria and obtained copies of the full text of potentially relevant references. Two review authors (HWN and NL) independently assessed the eligibility of retrieved papers. We resolved differences by discussion or by appeal to a third review author (TD), if necessary. We documented reasons for exclusion. The second update included 
all titles and abstracts from October 2013 until July 2017 retrieved by electronic searches of MEDLINE, Embase, and CENTRAL. Two review authors (STP and MB) selected and independently assessed studies using the same procedure that was used in the primary review and the first update. We resolved differences by discussion or by appeal to a third review author (HWN), if necessary.

\section{Data extraction and management}

Two review authors (HWN and NL) independently extracted data on characteristics of participants and interventions, study quality, and endpoints for included studies, and entered them onto a data extraction form specially developed for this review (Appendix 4). Two review authors (STP and MB) followed the same procedure for the second update.

When data on clinical efficacy and antigen-specific immunogenicity were missing from reports, we attempted to contact study authors to obtain the missing information. A third review author (WH or TD; or HWN during the second update) checked the results.

\section{Assessment of risk of bias in included studies}

We assessed the risk of bias in RCTs using the Cochrane 'Risk of bias' tool.

No standard tools are available to evaluate validity for non-RCTs. For these studies, we evaluated the risk of bias using the following four domains (Table 1 ).

- Sample definition and selection.

- Clear definition of inclusion/exclusion criteria.

- Representative selection.

- Adequate description of baseline characteristics.

- Interventions.

- Clear specification.

- Concurrent/concomitant treatment.

- Outcomes.

- Specifications of outcome measures.

- Relevance of outcome measures.

- Reporting of outcome measures.

- Statistical analysis.

- Adequate rationale for numbers of participants included.

- Adequate description of withdrawals/exclusions during the study.

- Adequate presentation of results.

We selected these domains as representative for, and applicable to, non-randomised non-controlled studies from a list of 12 quality domains and items deemed to be pivotal to the assessment of nonRCTs (Deeks 2003).

Two review authors (HWN and NL) carried out the 'Risk of bias' assessment. We resolved discrepancies by discussion; if necessary, we consulted a third review author (WH or TD). For the second update, two review authors (STP and MB) carried out the 'Risk of bias' assessment. We resolved discrepancies by discussion; if necessary, we consulted a third review author (HWN).

\section{Data synthesis}

This review provides a narrative analysis because the included studies are highly heterogeneous in terms of intervention and outcome measures. Furthermore, publications often presented data with insufficient details (e.g. lack of standard deviations (SDs), presentation of only some of the multiple outcomes), and it was difficult for review authors to obtain additional information from report authors. Therefore we agreed that quantitative metaanalysis and calculation of effect size estimates would be neither meaningful nor appropriate for this review. We limited analysis to a structured summary and discussion of available studies and findings.

\section{Certainty of the evidence}

We assessed the certainty of the evidence for main outcomes using GRADE (Grading of Recommendations Assessment, Development and Evaluation) criteria (Guyatt 2008), and we presented the main findings along with our judgements in a 'Summary of findings' table.

We will present the overall certainty of the evidence for each outcome according to the Grading of Recommendations Assessment, Development and Evaluation (GRADE) approach (Guyatt 2008), which takes into account issues related not only to internal validity (risk of bias, inconsistency, imprecision, publication bias for quantitative studies) but also to external validity (directness of results).

We downgraded the evidence from 'high' certainty by one level for serious (or by two for very serious) concerns for each limitation.

- High-certainty: we are very confident that the true effect lies close to that of the estimate of the effect.

- Moderate-certainty: we are moderately confident in the effect estimate: the true effect is likely to be close to the estimate of the effect, but there is a possibility that it is substantially different.

- Low-certainty: our confidence in the effect estimate is limited: the true effect may be substantially different from the estimate of the effect.

- Very low-certainty: we have very little confidence in the effect estimate: the true effect is likely to be substantially different from the estimate of effect.

For qualitative studies, we would upgrade for large consistent effect, dose response, and confounders that only reduced the effect size.

\section{RES U L T S}

\section{Description of studies}

\section{Results of the search}

\section{Initial version of the review}

Leffers 2010

Upon completing electronic searches of MEDLINE and Embase, we selected 56 out of 311 abstracts as potentially compliant with the selection criteria of this review and retrieved the full texts. Evaluation of the retrieved full texts resulted in the exclusion of 26 papers (see Excluded studies). In addition to the 30 selected full texts, we identified another 14 abstracts by handsearching the proceedings of the periodic meetings specified in the Methods section. We contacted study authors for manuscripts but obtained no full texts for these abstracts. Together, the 44 selected full texts and meeting abstracts described a total of 35 studies. A search 
of the prospective trial register www.clinicaltrials.gov resulted in identification of an additional 26 studies. We could retrieve a full text or meeting abstract for only four of these and found that only one study complied with our inclusion criteria (Sabbatini 2007). The remaining studies were either ongoing $(n=15)$ or completed but not yet published $(n=6)$. A search of CENTRAL $(2009$, Issue 3$)$ yielded no additional studies. Thus, we included a total of 36 studies in this review. Generally, we selected the most recent peer-reviewed publication as the primary reference.

\section{First update of the review}

\section{Leffers 2014}

For the first update of this review, electronic searches of MEDLINE and Embase yielded 158 records, which resulted in an additional 23 included papers and 10 excluded papers (Characteristics of excluded studies). For five studies in the previous version of this review, a full-text publication, update, or additional paper was now available. A search of CENTRAL (2013, Issue 3) did not yield additional studies. A search of clinicaltrials.gov resulted in two additional published studies. Furthermore, we identified 26 relevant studies without available results (Characteristics of ongoing studies). Twelve studies are currently recruiting participants, four studies are ongoing but not recruiting, nine studies are classified as completed, and for two studies status is unknown. Overall, we included an additional 19 studies in the update of this review, resulting in a total of 55 included studies involving 3051 women (Characteristics of included studies).

\section{Second update of the review}

For the second update of the review, an electronic search of CENTRAL, MEDLINE, and Embase yielded 266 records, which resulted in an additional nine included papers and nine excluded papers (Characteristics of excluded studies). For two studies identified in the previous version of this review, a full-text publication, update, or additional paper was now available.

A search of ongoing studies identified from the last update in clinicaltrials.gov revealed four additional published studies, three of which are included in this update. In addition, five studies were completed for which no results were published, four studies are still recruiting, and for one study status remains unknown. We removed four studies from the Ongoing studies section because the study had been terminated, or because studies did not include women with epithelial ovarian cancer. Furthermore, we identified 22 relevant new ongoing studies without available results (Characteristics of ongoing studies).

Overall, we included an additional 12 studies in the update of this review, resulting in a total number of 67 included studies involving 3632 women (Characteristics of included studies).

\section{Included studies}

The 67 studies included in this updated review were all published in English (Characteristics of included studies; Table 2).

\section{Design}

As we expected, most studies were uncontrolled phase I or II studies (52/67). Only four studies were randomised placebo-controlled studies (Berek 2001; Berek 2004; Berek 2009; Sabbatini 2013). Eleven studies randomly allocated participants to different regimens (Baumann 2011; Braly 2009; Chu 2012; Freedman 1998; Goh 2013; Gray 2016; Heiss 2010; Lennerz 2014; Method 2002; Sabbatini 2006; Sabbatini 2017). Five studies retrospectively studied the immunogenicity of a previously applied immunoscintigraphic agent (Buzzonetti 2014; Möbus 2003; Noujaim 2001; Schultes 1998; Wagner 1993).

\section{Sample sizes}

The median number of women with epithelial ovarian cancer treated per study was 20 (range 2 to 888). Twenty-one studies included fewer than 10 participants. Twenty studies also included participants with other types of cancer (Antonilli 2016; Berinstein 2012; Brossart 2000; Dhodapkar 2012; Gribben 2005; Gulley 2008; Heiss 2010; Kaumaya 2009; Le 2012; Lennerz 2014; Letsch 2011; Mohebtash 2011; Morse 2011; Odunsi 2012; Ohno 2009; Peethambaram 2009; Sandmaier 1999; Ströhlein 2009; Takeoka 2017; Tsuda 2004). Only 13 studies provided a sample size calculation or rationale (Baumann 2011; Berek 2004; Berek 2009; Braly 2009; Gribben 2005; Heiss 2010; Leffers 2009a; Rahma 2012; Sabbatini 2006; Sabbatini 2007; Sabbatini 2012; Sabbatini 2013; Vermeij 2012).

\section{Participants}

As was expected, disease status at study entry varied largely between studies (Table 2). Participants with evidence of residual or recurrent disease after treatment were most frequently included (30/67) (Baumann 2011; Brossart 2000; Dijkgraaf 2015; Ehlen 2005; Galanis 2010; Gordon 2004; Gribben 2005; Gulley 2008; Heiss 2010; Kaumaya 2009; Kawano 2014; Le 2012; Leffers 2009a; MacLean 1992; MacLean 1996; Möbus 2003; Mohebtash 2011; Nicholson 2004; Noujaim 2001; Odunsi 2014; Peethambaram 2009; Ströhlein 2009; van Zanten-Przybysz 2002; Vermeij 2012). Eight studies included participants with and without evidence of disease after prior therapy (Antonilli 2016; Berinstein 2012; Braly 2009; ChianeseBullock 2008; Lennerz 2014; Odunsi 2007; Sabbatini 2006; Tsuda 2004). Seventeen studies included participants with complete response to therapy for primary or recurrent disease (Berek 2001; Berek 2004; Berek 2009; Buzzonetti 2014; Chu 2012; Diefenbach 2008; Goh 2013; Gray 2016; Imhof 2013; Morse 2011; Odunsi 2012; Rahma 2012; Sabbatini 2000; Sabbatini 2007; Sabbatini 2012; Sabbatini 2013; Sabbatini 2017). One study administered treatment together with adjuvant chemotherapy after primary cytoreductive surgery (Braly 2009). The remaining 18 studies did not report disease status at study entry (Berinstein 2013; Dhodapkar 2012; Freedman 1998; Kobayashi 2014; Letsch 2011; Ma 2002; Method 2002; Nishikawa 2006; O'Cearbhaill 2016; Ohno 2009; Pfisterer 2006; Reinartz 2004; Sandmaier 1999; Schultes 1998; Suzuki 2016; Takeoka 2017; Takeuchi 2013; Wagner 1993).

\section{Interventions}

Most studies described antibody therapy (22/55), usually targeting cancer antigen (CA)-125 (17/22 (2347 women)). Most studies included only one target antigen in the vaccine, but 15 studies simultaneously targeted multiple antigens (Antonilli 2016; Berinstein 2012; Chianese-Bullock 2008; Chu 2012; Gulley 2008; Imhof 2013; Kawano 2014; Kobayashi 2014; Mohebtash 2011; Morse 2011; O'Cearbhaill 2016; Sabbatini 2007; Sabbatini 2017; Takeuchi 2013; Tsuda 2004). Antibodies were usually administered intravenously (12/22). For other vaccine types, subcutaneous injections were most common (29/43). 
Fifteen out of 55 studies did not allow concurrent treatment with immunomodulatory drugs. In an additional 20 studies, concomitant immunomodulatory agents were not part of the studied intervention but study authors made no explicit statements in the protocol about prohibition of such drugs. For 27 studies, immunomodulatory drugs were part of the protocol (i.e. carboplatin-paclitaxel, gemcitabine, doxorubicin and decitabine, cyclophosphamide, interleukin (IL)-2 \pm granulocytemacrophage colony-stimulating factor (GM-CSF), OK-432, OPT-821, PegIntron, toll-like receptor agonist poly-ICLC or resiquimod, or diphenhydramine) and one of these allowed interruption of immunotherapy by chemotherapy for progressive disease (Reinartz 2004). Furthermore, two retrospective studies explicitly mentioned that concurrent chemotherapy was allowed at the discretion of the treating clinician (Möbus 2003; Wagner 1993).

\section{Outcomes}

Information on immunological responses, clinical responses, survival, and adverse events was available for $63,43,44$, and 54 studies, respectively.

\section{Excluded studies}

A summary of the excluded studies is given in the Characteristics of excluded studies table. Frequent reasons for exclusion were inclusion of too few participants with ovarian cancer, use of antigen non-specific immunotherapy, and the impossibility of distinguishing results for women with ovarian cancer from results for other study participants.

\section{Risk of bias in included studies}

We included GRADE ratings for all primary outcomes. We rated survival as high but all other primary outcomes as very low, as is displayed in Summary of findings for the main comparison.

We evaluated risk of bias using the Cochrane 'Risk of bias' tool (Higgins 2011). Results of individual studies (both RCTs and NRSs) are available in the Characteristics of included studies table. The fact that for four of 16 RCTs only meeting abstracts were available hindered assessment of risk of bias. The 14 trials for which we could retrieve full texts also did not report on some of the items in the 'Risk of bias' tool. This substantial lack of information means it is highly likely that included studies are subject to biases, and it is therefore difficult to make any statements about the validity of the included RCTs (Figure 1).

Figure 1. 'Risk of bias' graph: review authors' judgements about each risk of bias item presented as percentages across all included studies. The high risk of selection bias in the majority of included studies is a reflection of the large number of uncontrolled studies included in this review. The risk of remaining biases could not be adequately judged for the included uncontrolled studies, thus explaining the large percentage of missing risk assessments.

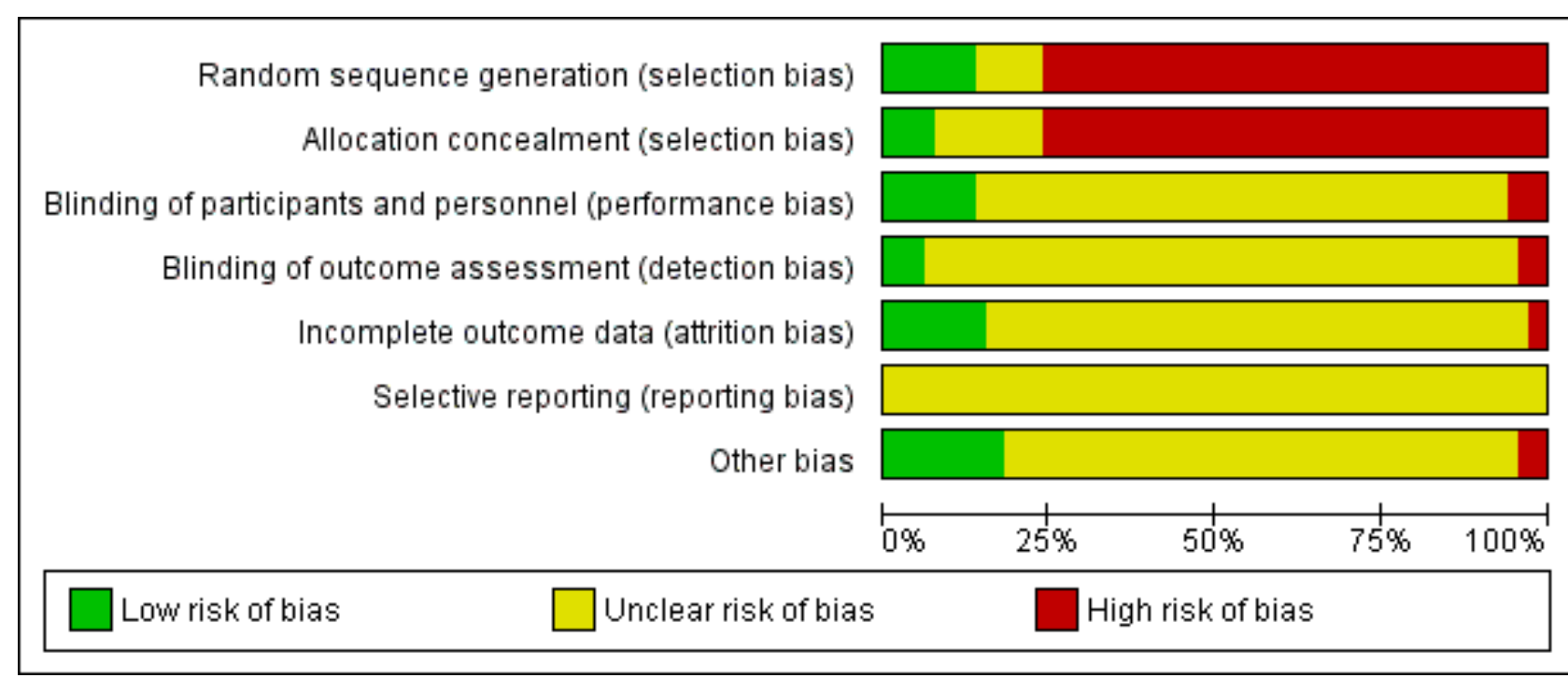

In addition to using the 'Risk of bias' tool, we evaluated nonRCTs using the checklist provided in Table 1 . An overview of these results is provided in Table 3. Important observations from this table include lack of clearly defined inclusion/exclusion criteria in 13 out of 51 studies and serious under-reporting of baseline characteristics in 31 out of 51 studies; this combination makes it impossible to evaluate whether the study populations were representative of the true population. Although most studies carefully described the investigational interventions (47 out of 51 ), information on allowance or application of concomitant immunomodulatory treatment was frequently absent (24 out of 51). Albeit a clear description of outcome measures was available for 35 studies, adequate calculation of sample size based on a clearly defined primary outcome measure was available for only five studies. Furthermore, the applied checklist shows that justification for withdrawals and exclusions during the study, as well as presentation of study results, requires serious attention in the reports of these non-randomised studies.

Based on the above, the risk of bias of studies included in this systematic review cannot be neglected. Especially selection bias (selection of a treatment population not comparable to the control group or the true population), attrition bias (inadequate reporting of withdrawal and exclusions during the study, resulting 
in possible overestimation or underestimation of effects), and selective reporting bias are likely to affect the studies included in this review. The effects of interventions described below must therefore be interpreted with prudence.

\section{Allocation}

As can be deduced from the Characteristics of included studies table, we were unable to identify the methods of randomisation and allocation used for several randomised studies, which means that we cannot rule out a selection bias for these studies. For the remaining RCTs, selection bias does not seem likely.

However most included studies were early-phase non-randomised studies including only a single study arm. Selection bias in these studies may have occurred in two ways: (1) by selective inclusion of participants with no other treatment options owing to endstage disease, at which point function of the immune system may also be seriously impaired, thus resulting in an underestimation of immunogenicity and possible clinical benefit of a given vaccine, or (2) via selective recruitment of fairly immunocompetent patients with no evidence of disease, resulting in a possible overestimation of immunogenicity and possible clinical benefit of a given vaccine.

\section{Blinding}

Inherent to the study design, no non-RCTs blinded participants or treating (study) physicians. All participants may have derived benefit from the additional attention awarded to them as participants in a study, and thus performance bias may have influenced the results of these studies. Furthermore, it is unclear whether for these studies, outcome assessors were aware of the clinical condition of patients; thus detection bias may have occurred in these studies.

Only five RCTs described blinding of patients, caregivers, and/or outcome assessors; all compared antibody therapy versus placebo (Berek 2001; Berek 2004; Berek 2009; Sabbatini 2013; Sabbatini 2017). The other RCTs compared dosage levels (Baumann 2011; Freedman 1998; Lennerz 2014), administration route (Sabbatini 2006), number of gifts of a given drug (Method 2002), timing of the intervention in relation to standard chemotherapy (Braly 2009), addition of an immunomodulatory drug (Chu 2012), or immunotherapeutic intervention compared with standard of care (Goh 2013; Gray 2016; Heiss 2010). Given these study designs, we believe that for most of these studies, risk of performance bias is low. Information on blinding of outcome assessors is frequently missing, and risk of detection bias cannot be reliably judged.

\section{Incomplete outcome data}

We deemed that only one RCT had high risk of attrition bias based on differences in withdrawals between groups (Heiss 2010). Risk of attrition bias was unclear for nine other RCTs (Berek 2001; Buzzonetti 2014; Freedman 1998; Goh 2013; Gray 2016; Lennerz 2014; Method 2002; Sabbatini 2006; Sabbatini 2017), and risk was low for the remaining RCTs (Baumann 2011; Berek 2004; Berek 2009; Braly 2009; Chu 2012; Sabbatini 2013).

\section{Selective reporting}

None of the included studies had a publicly available registered study protocol. It is therefore unclear whether studies selectively reported outcomes.

\section{Other potential sources of bias}

Given the elapsed time since publication of the meeting abstract, a publication bias is likely to exist for two out of three RCTs for which only a meeting abstract was available (Berek 2001; Freedman 1998).

\section{Effects of interventions}

See: Summary of findings for the main comparison Antigenspecific immunotherapy for ovarian carcinoma

\section{Primary outcomes}

\section{Clinical efficacy}

\section{Tumour responses}

Forty-three studies evaluated clinical responses to therapy (Table 4). No RCTs evaluated tumour response (Berek 2001; Berek 2004; Berek 2009; Gray 2016; Sabbatini 2013; Sabbatini 2017). In reports on these studies, criteria for evaluation and/or explicit descriptions of tumour responses per patient as well as the time point at which the evaluation took place were frequently not available. For studies that did mention evaluation of tumour responses, response outcomes were based on CA-125 levels combined with tumour imaging (Baumann 2011; Chianese-Bullock 2008; Chu 2012; Diefenbach 2008; Dijkgraaf 2015; Ehlen 2005; Galanis 2010; Gordon 2004; Gulley 2008; Leffers 2009a; Ohno 2009; Rahma 2012; Sabbatini 2006; Ströhlein 2009; Tsuda 2004; van Zanten-Przybysz 2002; Vermeij 2012), CA-125 alone (Nicholson 2004; Wagner 1993), or imaging alone (Le 2012; Odunsi 2007; Peethambaram 2009; Reinartz 2004; Sabbatini 2012; Takeuchi 2013). Eighteen studies explicitly mentioned evaluation of imaging according to the internationally accepted WHO or RECIST criteria (Baumann 2011; Dijkgraaf 2015; Galanis 2010; Kawano 2014; Kobayashi 2014; Leffers 2009a; Lennerz 2014; Odunsi 2014; Ohno 2009; Rahma 2012; Reinartz 2004; Sabbatini 2012; Suzuki 2016; Takeoka 2017; Takeuchi 2013; Tsuda 2004; Vermeij 2012), and only six studies evaluated CA-125 levels according to GCIG criteria or described CA-125 levels in such a way that evaluation according to these criteria was possible for at least some participants (Baumann 2011; Dijkgraaf 2015; Galanis 2010; Leffers 2009a; van Zanten-Przybysz 2002; Vermeij 2012). It is striking that eight studies stated that study authors evaluated tumour responses but did not provide these results in their publications (Dhodapkar 2012; Diefenbach 2008; Gulley 2008; Imhof 2013; Method 2002; Odunsi 2007; Reinartz 2004; Wagner 1993). Only seven studies reported complete or partial tumour responses in a small fraction of patients with evidence of disease at study entry (Baumann 2011; Dijkgraaf 2015; Gordon 2004; Kaumaya 2009; Kawano 2014; Odunsi 2007; Takeuchi 2013). These results must be interpreted with caution, as two of these studies did not define criteria for response evaluation (Gordon 2004; Odunsi 2007).

\section{Post-immunotherapy treatment response}

Although studies generally report a period of follow-up to obtain information on survival, most studies provide no report on subsequent treatment with and response to secondary chemotherapy. Nine studies mention that participants were treated with chemotherapy after immunotherapy (Berek 2004; Gordon 2004; Gribben 2005; Leffers 2009a; Möbus 2003; Odunsi 2007; Reinartz 2004; Ströhlein 2009; van Zanten-Przybysz 2002), but only four non-comparative phase I/II studies report response to secondary chemotherapy in relation to immunological responses 
to immunotherapy (Gordon 2004; Gribben 2005; Leffers 2009a; Reinartz 2004).

Reinartz 2004 provided a preliminary report on clinical responses of 28 out of 42 participants treated with chemotherapy for clinically relevant progression during or after antibody therapy in conjunction with the induction of human-anti-mouse and antianti-idiotype antibodies. Although both types of participants with a complete response had strong humoral responses, researchers observed similar or stronger antibody responses for participants with stable or progressive disease. In another study, shortly after monotherapy with a monoclonal antibody, 13 out of 20 participants received chemotherapy combined with the monoclonal antibody. Researchers in this study observed clinical responses to chemoimmunotherapy only in patients with cellular responses to CA-125 and/or autologous tumour (Gordon 2004). A study of synthetic long peptides targeting p53 showed no improvement in survival or tumour responses to secondary chemotherapy (Leffers 2009a). Finally, the authors of a study investigating plasmid DNA vaccination targeting CYP1B1 suggest that treatment has led to improved responses to third-line therapy but included no control group, nor do we find this observation convincing when only patients with ovarian cancer are considered (Gribben 2005).

\section{Survival and time to relapse}

Definitions of survival used in the different studies varied greatly (Table 5 and Table 6). Furthermore, reliable statements about survival (dis)advantages can be made only on the basis of RCT findings. Only six studies were designed to primarily evaluate survival; however, investigators found no statistically significant differences in time to relapse and/or overall survival between patients treated with a monoclonal antibody and those given placebo (Berek 2001; Berek 2004; Berek 2009; Sabbatini 2013). Another study compared antigen-specific immunotherapy versus a non-specific immunotherapy and noted no significant differences in progression-free survival (Sabbatini 2017). Another study compared MUC1 dendritic cell therapy versus standard of care and reported no significant differences in progressionfree survival and overall survival. However, when patients were divided into two subgroups (first and second clinical remission), a significant difference in overall survival and progression-free survival was evident among those with a second clinical remission. Researchers included a small number of participants in the trial and median overall survival of the treated group has not yet been reached; therefore these results must be interpreted with caution (Gray 2016). Many non-RCTs also evaluated survival, frequently by comparing survival of patients with robust immunological responses versus that of patients with no or weak immunological responses to treatment (Table 5 and Table 6). These results should be interpreted with great caution, as shorter survival among non-responders could merely be a reflection of the general condition of these patients and might reflect well-known clinical and pathological prognostic parameters. Patient numbers in the non-comparative groups were often too low to permit a reliable conclusion.

\section{Antigen-specific immunogenicity}

\section{Humoral responses}

Monoclonal antibodies may induce anti-idiotype antibodies (Ab2), directed primarily against the administered monoclonal antibody, as well as anti-anti-idiotype antibodies (Ab3), directed towards the target antigen. Anti-idiotype and anti-anti-idiotype antibodies were evaluated in 10 out of 22 studies and 9 out of 22 studies, respectively (Table 7 and Table 8). Response percentages varied greatly (Ab2: $3 \%$ to $100 \%$, Ab3: $0 \%$ to $100 \%$ ).

Twenty-one studies of other vaccine types evaluated the induction of antigen-specific antibodies as shown by enzyme-linked immunosorbent assay (ELISA) or luminex assay; however only 11 of these studies clearly defined when an antibody titre or concentration was considered positive (Table 9) (Diefenbach 2008; Galanis 2010; Kaumaya 2009; Kawano 2014; O'Cearbhaill 2016; Odunsi 2014; Sabbatini 2007; Sabbatini 2012; Sabbatini 2017; Sandmaier 1999; Takeoka 2017). In addition, the study combining an NY-ESO-1 vaccine with chemotherapy and an anti-methylation agent tested humoral response with ELISA to 22 recombinant proteins that were not included in the vaccine and showed de novo serum reactivity to at least one of those proteins in all analysed participants $(n=3)$, suggesting that combination regimens may lead to a broadened profile of anti-tumour immune response in vivo (Odunsi 2014). Results show large differences in percentages of patients with measurable antigen-specific antibodies (IgG: $0 \%$ to $96 \%$ ). Possible explanations for these broad ranges include differences in (1) response definition, (2) number of treatment cycles after which humoral responses were measured, and (3) targeted antigens.

\section{Cellular responses}

Thirteen out of 20 monoclonal antibody studies investigated induction of T-cells against the target antigen (Table 10). Investigators evaluated the presence of antigen-specific T-cells using commonly applied tests, such as interferon-gamma (IFNү) ELISPOT (Ehlen 2005; Gordon 2004; Method 2002; Sabbatini 2006), proliferation assay (Ma 2002; Noujaim 2001; van ZantenPrzybysz 2002), cytokine profiling (Noujaim 2001; Pfisterer 2006), IFN- $\gamma$ secretion assay (Ströhlein 2009), and IFN- $\gamma$ intracellular staining assay (Buzzonetti 2014). One study used the leucocyte migration inhibition assay, which nowadays is rarely used (Wagner 1993). As described above for humoral responses, response definitions were frequently lacking or inadequate. Nevertheless, results showed cellular immunity against CA-125 for $21 \%$ to $80 \%$ of participants. One study retrospectively compared cellular immune response after CA-125 monoclonal antibody treatment versus placebo but noted no significant differences (31.8\% intervention vs $26.3 \%$ control) (Buzzonetti 2014). Antibody treatment targeting the membrane folate receptor did not however induce cellular responses (van Zanten-Przybysz 2002). Only two studies reported recognition of autologous tumour cells by induced T-cells, describing positive responses in five out of eight and one out of two patients, respectively (Gordon 2004; Ströhlein 2009).

A total of 35 out of 44 studies evaluated antigen-specific cellular immune responses with the use of other vaccine types (Table 11). The most frequently used assay was the IFN $-\gamma$ ELISPOT assay, which sometimes was used to separately analyse CD4+ and/or CD8+ cells. Again, response definitions for positive and/or vaccine-induced responses were frequently absent or unclear (15 out of 44). Six of eight studies targeting NY-ESO-1 induced antigen-specific T-cells, with percentages of patients with NY-ESO-1-specific CD8+ ranging from 33\% to 92\% (Dhodapkar 2012; Diefenbach 2008; Nishikawa 2006; Odunsi 2007; Odunsi 2012; Odunsi 2014; Sabbatini 2012), and one study did not report the results for ovarian cancer participants separately (Dhodapkar 2012). Another study showed a positive NY- 
ESO-1-specific CD8 + T-cell induction by IFN- $\gamma$ catch assay ( $1 \%$ to $5 \%$ positive CD8+ T-cells) (Takeoka 2017). After treatment with vaccines targeting $p 53$, investigators observed $p 53$-specific T-cells in $64 \%$ to $100 \%$ of patients, irrespective of the type of vaccine (Leffers 2009a; Rahma 2012; Vermeij 2012). One study compared p53-specific Tcell responses between treatment with a $p 53$-targeting vaccine plus chemotherapy and PegIntron versus chemotherapy and PegIntron versus chemotherapy alone. Immune response rates were $100 \%$, $22 \%$, and $0 \%$, respectively (Dijkgraaf 2015), indicating that applying chemotherapy and PegIntron at the same time as antigen-targeted immunotherapy may induce a stronger immune response. Studies targeting multiple antigens demonstrated antigen-specific cellular immunity with varying immunogenicity of the different antigens targeted (Antonilli 2016; Berinstein 2012; Brossart 2000; ChianeseBullock 2008; Chu 2012; Gray 2016; Kaumaya 2009; Kawano 2014; Lennerz 2014; Mohebtash 2011; Morse 2011; Suzuki 2016; Tsuda 2004). Finally, a study testing dendritic cell-based immunotherapy showed no induction of IFN- $\gamma$-specific CD4+ and CD8+ cells by flow cytometry, although tetramer staining of WT1-specific cytotoxic Tlymphocytes did show an increase in 12 out of 17 patients (70.6\%) (Kobayashi 2014).

\section{Secondary outcomes}

\section{Carrier-specific immunogenicity}

Most studies using a monoclonal antibody (18/22) used a murine antibody, two studies used a trifunctional rat-mouse hybrid (Baumann 2011; Heiss 2010), and one study used a chimeric antibody construct (van Zanten-Przybysz 2002). Next to antigenspecific immunity, 16 studies assessed the induction of humananti-mouse antibodies (HAMAs) using HAMA-specific ELISA assays (Table 12). HAMAs were present in $4 \%$ to $97 \%$ of participants immunised (Baumann 2011; Berek 2004; Braly 2009; Ehlen 2005; Gordon 2004; Method 2002; Möbus 2003; Pfisterer 2006; Reinartz 2004; Sabbatini 2006; Schultes 1998). It seems that this large variation between studies cannot be attributed to differences in dosage but is best ascribed to different definitions of a HAMA response (i.e. some studies report only robust responses, whereas others report all responses above a certain threshold). Furthermore, the point in time at which HAMA titres were measured is of importance, as responses increase in frequency and strength with repeated administration of the antibody (Baumann 2011; Gordon 2004; Method 2002; Möbus 2003).

Although eight studies investigated synthetic carbohydrate antigens conjugated to the keyhole limpet haemocyanin (KLH) carrier protein (Freedman 1998; MacLean 1992; MacLean 1996; O'Cearbhaill 2016; Sabbatini 2000; Sabbatini 2007; Sabbatini 2017; Sandmaier 1999), only one study reported on KLHspecific immunity (Sandmaier 1999). In this study, proliferative responses to stimulation with $\mathrm{KLH}$ and the $\mathrm{KLH}$-antigen complex were substantially stronger than responses to the synthetic carbohydrate itself in all women with ovarian cancer tested, similar to what has previously been reported for viral vectors.

Five studies reported use of recombinant viruses or bacteria as vectors (Galanis 2010; Gulley 2008; Le 2012; Mohebtash 2011; Odunsi 2012). Three of these studies reported that they investigated anti-vector immune responses. One study used a recombinant pox-virus induced anti-vector immunity for all participants with ovarian cancer (Gulley 2008). Another study used a recombinant measles virus and did not show any differences in anti-measles-antibody titres, although inclusion criteria required that included participants must be immune to measles virus (Galanis 2010). In the third study, use of live-attenuated listeria did result in virus-specific T-cells in some cancer patients; however, too few patients with ovarian cancer were tested to permit any conclusions regarding this specific disease entity (Le 2012).

\section{Adverse events}

For this review, we defined adverse events as any adverse changes in health or side effects that occurred in a clinical study participant receiving treatment, irrespective of whether the event could be attributed to the treatment received.

Although 56 studies mentioned adverse events; sufficiently detailed information on adverse events that occurred during the study was available for 43 out of 67 studies. Thirty-four studies explicitly mentioned local adverse events, all of which involved local administration of the vaccine (i.e. intradermal, intramuscular, or subcutaneous injection). When local adverse events were further specified, these were best summarised as pain at the injection site and local inflammatory responses (erythema, induration, pruritis). Researchers observed ulceration and/or abscesses at the injection site in nine of 89 participants with varying types of cancer participating in four studies (Berinstein 2012; Berinstein 2013; Freedman 1998; Gribben 2005). One study described a patient with a grade III infection presenting with lower-limb lymphoedema at the injection site, which was attributed to the vaccine. This patient underwent a pelvic lymphadenectomy during the primary debulking surgery, suggesting in this case that women who have undergone pelvic lymphadenectomy might be less suitable for vaccination of the lower limbs (Kawano 2014).

Systemic adverse events occurred in 42 studies, and four studies explicitly reported that systemic adverse events did not occur. Two studies explicitly reported autoimmunity. In one study, a patient with strong immunological responses to the vaccine developed symptomatic hypothyroidism necessitating replacement therapy (Diefenbach 2008). Study authors described minor induction of anti-nuclear antibodies (grade I according to Common Terminology Criteria for Adverse Events (CTCAE) v4.0 (Trotti 2003)) for two patients receiving a multi-peptide vaccine (Chianese-Bullock 2008). Allergic reactions occurred in a total of 14 participants (Berek 2009; Braly 2009; Ehlen 2005; MacLean 1992; Möbus 2003; Pfisterer 2006; Ströhlein 2009). Allergic reactions (e.g. hypersensitivity, allergic exanthema, urticaria) were mild and were easily managed. Continuation of study treatment did not result in renewed allergic reactions (Braly 2009; Ehlen 2005; Möbus 2003; Pfisterer 2006). Treatment with chemotherapy, an anti-methylation agent, and an NY-ESO-1-targeting vaccine resulted in clinically manageable adverse events (Odunsi 2014).

Other reported systemic adverse events, irrespective of whether attributable to the investigated drug, included haematological changes (e.g. anaemia, leucopenia), flu-like symptoms (including fatigue, myalgia, arthralgia, headache, fever, and chills), and gastrointestinal events (e.g. nausea, vomiting, diarrhoea, abdominal pain), most of which were classified as grade I or II events. Thirty-three studies reported serious (CTCAE grade III or IV) adverse events that varied from recurrent or progressive disease to local ulceration at the injection site, and from abdominal pain, neutropenia, and fever to elevated liver enzymes. One study compared standard of care versus MUC1 dendritic cell 
therapy. Respectively, $8 \%$ versus $27 \%$ of participants suffered an adverse event grade III or IV (Gray 2016). Another study combining vaccination with chemotherapy reported 10 high-grade adverse events, nine of which were attributed to the chemotherapy (Kawano 2014). In addition, one study comparing chemotherapy alone versus chemotherapy and PegIntron versus chemotherapy, PegIntron, and p53 vaccination reported grade III or IV adverse events in $50 \%$ of participants, with no significant differences between treatment groups (Dijkgraaf 2015). A study combining chemotherapy, an anti-methylation agent, and an NY-ESO-1targeting vaccine described three serious adverse events, which study authors did not attribute to any of the investigated drugs (Odunsi 2014). Twenty studies reported no serious adverse events. Ten studies did not mention lack or presence of serious adverse events (Berek 2001; Imhof 2013; Ma 2002; MacLean 1996; Möbus 2003; Nishikawa 2006; Noujaim 2001; Sandmaier 1999; Schultes 1998; Wagner 1993).

\section{DISCUSSION}

\section{Summary of main results}

The aim of this review was to evaluate the clinical and immunological efficacy of antigen-specific active immunotherapy in ovarian cancer, whilst also obtaining an impression of the safety and tolerability of this treatment modality. The antigenspecific active immunotherapy described in this review can largely be divided into two strategies: (1) administration of antibodies targeting a specific tumour antigen and (2) administration of, or parts of, a specific tumour antigen itself. As expected, most studies were non-randomised controlled trials (NRSs).

Data suggest that almost all strategies are capable of inducing an immunological response to some extent. Furthermore, only two studies evaluated recognition of autologous tumour cells in vitro, and no studies evaluated immune responses at the tumour site. Although obtaining autologous tumour material may be burdensome, such assays would be extremely valuable, as they comprise true interactions between induced immunity and tumour cells and as such could provide important information on how immunotherapeutic strategies can continue to be improved to reach clinical effectiveness. Even though comparison between studies is difficult, it seems that most antigen-specific therapies, independent of the target, are able to induce at least a minimal immune response.

Clinical responses to immunotherapy (i.e. tumour responses, responses to post-immunotherapy treatment, and survival benefits) were observed only incidentally, and their occurrence cannot be used to draw a reliable conclusion. The indication for immunotherapeutic treatment in the adjuvant setting is supported by the observation of enhanced antigen-specific responses to immunotherapy when combined with chemotherapeutic agents currently or previously used in the primary treatment of ovarian cancer (i.e. docetaxel or cyclophosphamide) (Garnett 2008; Laheru 2008). However, four large randomised controlled trials (RCTs) using a monoclonal cancer antigen (CA)-125 antibody in the adjuvant setting after successful primary therapy did not demonstrate any differences in time to relapse and/or overall survival between treatment and placebo arms (Berek 2001; Berek 2004; Berek 2009; Sabbatini 2013), which indicates that despite immunogenicity, CA-125-targeted monoclonal antibody therapy is clinically ineffective. For studies of other vaccine types, no such conclusions can be made at this time, as large RCTs and more studies in the adjuvant rather than recurrent setting have yet to be performed to examine the different strategies.

Eighty per cent of studies reported adverse events in sufficient detail for interpretation. Study authors made a distinction between local and systemic events and further subdivided the latter into autoimmunity, allergy, and other adverse events. We did not evaluate whether adverse events could be or were considered attributable to the treatment studied, although for local adverse events, this is indisputably the case. Studies using intradermal, subcutaneous, or intramuscular application have frequently reported inflammatory reactions and pain at the injection site, with ulceration at the most severe side of the spectrum. Severe or life-threatening systemic adverse events occurred in approximately $50 \%$ of studies. Thirty per cent of studies explicitly described the lack of severe adverse events. For monoclonal antibody studies, researchers could identify no pattern suggestive of an underlying treatment-associated process and often considered events to be associated with ovarian cancer progression.

In summary, this review describes 67 immunotherapy studies including 3632 women with ovarian cancer. It seems that although all strategies described are capable of inducing immunological responses, be it humoral or cellular, clinical effectiveness thus far has not been convincingly demonstrated. The largest body of evidence is available for CA-125-directed antibody therapy, which has been studied in 2347 people participating in 17 studies. As only one study reported complete or partial clinical responses and four large RCTs did not demonstrate any clinical benefit of antibody treatment, we believe it is unlikely that the clinical effectiveness of CA-125-directed antibody therapy for ovarian cancer will ever be obtained. It is possible that inducing an immunological response alone is not enough to derive clinical benefit owing to immune suppressive characteristics of the tumour. To overcome this suppression, combining antigen-specific immunotherapy with other forms of immunotherapy (e.g. checkpoint inhibitors, chemotherapy, poly ADP ribose polymerase (PARP) inhibitors, anti-methylation agents) might be necessary to achieve clinical response. However, in view of the immunological responses and the usually mild side effects reported, we believe that further investigation of other antigen-specific active immunotherapy strategies in ovarian cancer is worthwhile.

\section{Overall completeness and applicability of evidence}

The most striking observations of this review unfortunately do not concern the aim of the review but address lack of uniformity in the conduct and reporting of early-phase immunotherapy studies.

According to the GRADE rating, only certainty for the primary outcome survival is assessed as 'high', whereas that for all other outcomes is assessed as 'very low' (Summary of findings for the main comparison). Of note, most of the RCTs that were analysed for survival were investigating a CA-125 monoclonal antibody. Their results may not be applicable in a similar way for other strategies using antigen-specific immune therapy for ovarian carcinoma.

Reliability of the results for clinical response to immunotherapy was questionable because clear response definitions were lacking, and because concomitant immunotherapy or administration of additional treatment after immunotherapy often was not described. Furthermore, for studies that used a monoclonal 
antibody targeting CA-125, use of CA-125 as a marker for clinical response is questionable. An additional important comment regarding the likelihood of clinical response to immunotherapy, especially in uncontrolled studies, which frequently include patients with recurrent disease, is the fact that this likelihood may be affected by disease status at the start of treatment (Leffers 2009).

In addition, antigen-specific humoral and/or cellular immunogenicity of different interventions showed great variation for both monoclonal antibody studies and studies examining other strategies. This variation may be attributed at least in part to variation in the immunological response definitions used by different study authors. Therefore it is not possible to reliably compare studies and infer which intervention and/or immunisation strategy is most promising for the induction of strong anti-tumour immunity.

A disturbing observation regarding adverse events is the lack of uniformity in adverse event reporting. Reporting of safety and tolerability of new treatment strategies should have high priority in all studies of investigational drugs, especially in uncontrolled phase I and II studies. To promote uniformity in adverse event evaluation and reporting, as well as comparability of adverse events between studies, in addition to the National Cancer Institute Common Terminology Criteria for Adverse Events ( $\mathrm{NCl}$ CTCAE) (Trotti 2003), the Brighton Collaboration has committed itself to developing standardised, widely disseminated, and globally accepted case definitions for an exhaustive number of adverse events following immunisation, as well as guidelines for data collection, analysis, and presentation (Brighton Collaboration 2009). These case definitions and guidelines are freely available, and we strongly recommend that, when applicable, they be used for all immunotherapeutic studies.

This review emphasises an aspect of immunotherapeutic studies that warrants serious attention in the immunotherapeutic scientific community, that is, lack of consensus on (1) what assays should be used to establish immunogenicity of an intervention (Britten 2008), (2) what cutoffs should be used to define true immunological responses, and (3) what response definitions should be used to determine clinical efficacy. Given these large inconsistencies, it is evident that elucidation of which type of immunological response is necessary for and/or is a surrogate marker of clinical activity of an immunotherapeutic intervention is burdensome.

\section{Quality of the evidence}

We assessed the included studies for risks of bias, using the Cochrane 'Risk of bias' tool. Risk of bias items, especially selection, attrition, and selective reporting bias, are likely to affect the studies included in this review.

It is interesting to note that for 10 studies described in this review, review authors collected study information only from a meeting abstract that was several years old. The lack of full-text manuscripts, even after contact was made with abstract authors, strongly suggests the existence of a publication bias. To avoid the disappearance of negative studies, registration of trials in a prospective trial register is widely recommended and is supported by the International Committee of Medical Journal Editors (ICMJE). However, at first, in 2005, registration was requested only for RCTs. Since July 1,2008 , all trials prospectively assigning human participants to one or more health-related interventions for evaluation of their effects on health outcomes are required to be registered in a clinical trial register approved by the World Health Organization (WHO). From the ongoing studies section, it is apparent that despite registration in a prospective trial register, studies may suffer from publication bias, as several relatively small studies that began more than five years ago have not yet been published to date nor closed according to the trial register. In addition to registration in trial registers, the uniform requirements for manuscripts submitted to biomedical journals drafted by the ICMJE encourage uniformity in reporting of clinical trials by stating ethical principles for the conduct and reporting of research and by providing recommendations related to specific elements of editing and writing. As is obvious from this review, the scientific community might benefit substantially if early-phase uncontrolled clinical trials would also strive for uniformity in trial conduct and reporting.

\section{Potential biases in the review process}

We minimised potential biases in the review process by searching the literature from a variety of sources with no restrictions on date of publication. At least two review authors independently extracted and assessed data.

To minimise the chances of error and bias, review authors adhered to Cochrane guidelines for selection of studies, extraction of data, and assessment of the certainty of evidence and potential risks of different types of biases in all included studies.

\section{Agreements and disagreements with other studies or reviews}

Our findings are in broad agreement with those presented by most systematic reviews on antigen-specific active immunotherapy for ovarian cancer (Drerup 2015; Hardwick 2016; Odunsi 2017). However, the focus of current publications leans more towards immunotherapy in general (e.g. whole tumour lysatetargeting immunotherapy, immune checkpoint blockade, cytokine induction, adoptive cell transfer) and not towards antigenspecific immunotherapy alone. The general consensus is that antigen-specific immunotherapy is sufficient for eliciting an immune response, but clinical response to monotherapy is only modest (Drerup 2015; Odunsi 2017). Combining antigen-specific immunotherapy with other types of immunotherapy, especially immune checkpoint blockade, is a promising approach to be examined by future researchers (Hardwick 2016; Odunsi 2017).

\section{AUTHORS' CONCLUSIONS}

\section{Implications for practice}

At this point, review authors have found no evidence of effective immunotherapy for ovarian cancer. Although promising immunological responses have been observed for most strategies evaluated, they do not coincide with clinical benefits for women with ovarian cancer. Furthermore, no immunological surrogate markers currently correlate with clinical outcomes. Therefore, until evidence of true clinical effectiveness is available, immunotherapy should not be offered as an alternative to standard therapy for primary or recurrent ovarian cancer. 


\section{Implications for research}

Our primary recommendation relates to the need for uniformity in trial conduct and reporting. Not until universally accepted immunological and clinical response definitions and guidelines for adverse events reporting are adopted for immunotherapeutic studies will it be possible to make any inferences about the effectiveness of immunotherapy as a treatment for ovarian cancer. Furthermore, expanding evaluation of immunogenicity to include recognition of autologous tumour is advisable. Given the usually mild side effects and the immunological responses witnessed in most studies, we believe that further investigation of antigen-specific active immunotherapy other than cancer antigen (CA)-125-targeted antibody therapy for ovarian cancer in randomised controlled trials is worthwhile. In addition, research combining antigen-targeted immunotherapy with other forms of immunotherapy to optimise response, and perhaps induce clinical response, is of interest.

\section{ACKN OWLEDGEMENTS}

We would like to thank all members of the Cochrane Gynaecological, Neuro-oncology, and Orphan Cancers Editorial Team for their support.

This project was supported by the National Institute for Health Research, via Cochrane Infrastructure funding to the Cochrane Gynaecological, Neuro-oncology, and Orphan Cancer Group. The views and opinions expressed therein are those of the authors and do not necessarily reflect those of the Systematic Reviews Programme, NIHR, NHS, or the Department of Health. 


\section{REFERE N CE S}

\section{References to studies included in this review}

\section{Antonilli 2016 \{published data only\}}

Antonilli M, Rahimi H, Visconti V, Napoletano C, Ruscito I, Zizzari IG, et al. Triple peptide vaccination as consolidation treatment in women affected by ovarian and breast cancer: clinical and immunological data of a phase $\mathrm{I} / \mathrm{II}$ clinical trial. International Journal of Oncology 2016;48:1369-78. [PUBMED: 26892612]

\section{Baumann 2011 \{published data only\}}

Baumann K, Pfisterer J, Wimberger P, Burchardi P, Kurzeder C, du Bois A, et al. Intraperitoneal treatment with the trifunctional bispecific antibody catumaxomab in patients with platinumresistant epithelial ovarian cancer: a phase lla study of the AGO Study Group. Gynecologic Oncology 2011;123:27-32.

\section{Berek 2001 \{published data only\}}

Berek JS, Ehlen TG, Gordon A, Nicodemus CF, Schultes B, Whiteside TL, et al. Interim analysis of a double blind study of Ovared mAb B43.13 (OV) versus placebo (PBO) in patients with ovarian cancer. American Society of Clinical Oncology Annual Meeting. 2001.

\section{Berek 2004 \{published data only\}}

* Berek JS, Taylor PT, Gordon A, Cunningham MJ, Finkler N, Orr J, et al. Randomized, placebo-controlled study of oregovomab for consolidation of clinical remission in patients with advanced ovarian cancer. Journal of Clinical Oncology 2004;22(17):3507-16.

Berek JS, Taylor PT, Nicodemus CF. CA125 velocity at relapse is a highly significant predictor of survival post relapse: results of a 5-year follow-up survey to a randomized placebocontrolled study of maintenance oregovomab immunotherapy in advanced ovarian cancer. Journal of Immunotherapy 2008;31(2):207-14

\section{Berek 2009 \{published data only\}}

* Berek J, Taylor P, McGuire W, Smith LM, Schultes B, Nicodemus CF. Oregovomab maintenance monoimmunotherapy does not improve outcome in advanced ovarian cancer. Journal of Clinical Oncology 2009;27:418-25.

Berek J, Taylor PT, McGuire WP, Smith LM, Schultes B, Nicodemus CF. Evaluation of maintenance monoimmunotherapy to improve outcomes in advanced ovarian cancer (OV CA). ASCO Annual Meeting. 2008.

\section{Berinstein 2012 \{published data only\}}

Berinstein NL, Karkada M, Morse MM, Nemunaitis JJ, Chatta G, Kaufman H, et al. First-in-man application of a novel therapeutic cancer vaccine formulation with the capacity to induce multi-functional T cell responses in ovarian, breast and prostate cancer. Journal of Translational Medicine 2012;10:156.

\section{Berinstein 2013 \{published data only\}}

Berinstein NL, Oza AM, Odunsi K, Karkada M, Villella JA, Nemunaitis JJ, et al. Effect of oral cyclophosphamide on the immunogenicity of DPX-Survivac in ovarian cancer patients: results of a phase I study. American Society of Clinical Oncology Annual Meeting. 2013.

\section{Braly 2009 \{published data only\}}

Braly P, Chu C, Collins Y, Edwards R, Gordon A, McGuire W, et al. Prospective evaluation of front-line chemo-immunotherapy (C-IT) with oregovomab (2 alternative dosing schedules) carboplatin-paclitaxel (C-P) in advanced ovarian cancer (OC). American Society of Clinical Oncology Annual Meeting. 2007.

* Braly P, Nicodemus CF, Chu C, Collins Y, Edwards R, Gordon A, et al. The immune adjuvant properties of front-line carboplatinpaclitaxel: a randomised phase 2 study of alternative schedules of intravenous oregovomab chemo-immunotherapy in advanced ovarian cancer. Journal of Immunotherapy 2009;32:54-65.

Method M, Gordon A, Smith LM, Nicodemus CF. Oregovomab immune-modulating antibody therapy concurrent to standard chemotherapy of epithelial ovarian cancer (EOC): feasibility and initial clinical experience. Society of Gynecologic Oncologists Annual Meeting on Women's Cancer. 2006.

\section{Brossart 2000 \{published data only\}}

Brossart P, Wirths S, Stuhler G, Reichardt VL, Kanz L, Brugger W. Induction of cytotoxic T-lymphocyte responses in vivo after vaccinations with peptide-pulsed dendritic cells. Blood 2000;96(9):3102-8

\section{Buzzonetti 2014 \{published data only\}}

Buzzonetti A, Fossati M, Catzola V, Scambia G, Fattorossi A, Battaglia A. Immunological response induced by abagovomab as a maintenance therapy in patients with epithelial ovarian cancer: relationship with survival - a substudy of the MIMOSA trial. Cancer Immunology Immunotherapy 2014;63:1037-45. [PUBMED: 24952307]

\section{Chianese-Bullock 2008 \{published data only\}}

Chianese-Bullock KA, Irvin WP, Petroni GR, Murphy C, Smolkin M, Olson WC, et al. A multipeptide vaccine is safe and elicits T-cell responses in participants with advanced stage ovarian cancer. Journal of Immunotherapy 2008;31(4):420-30.

\section{Chu 2012 \{published data only\}}

Chu CS, Boyer J, Coukos G, Rubin SC, Morgan MA, Bendig DL, et al. Autologous dendritic cell (IDD-6) vaccination as consolidation for advanced ovarian cancer. Society of Gynecologic Oncologists Annual Meeting on Women's Cancer. 2008.

* Chu CS, Boyer J, Schullery DS, Gimotty PH, Gamerman V, Bender J, et al. Phase I/II randomized trial of dendritic cell vaccination with or without cyclophosphamide for consolidation therapy of advanced ovarian cancer in first or second remission. Cancer Immunology Immunotherapy 2012;61:629-41.

\section{Dhodapkar 2012 \{published data only\}}

Dhodapkar M, Zhao B, Wang D, Lutzky RD, Carvajal RD, Keohan M, et al. A phase I trial of a novel vaccine targeting NY- 
ESO-1 to the dendritic cell receptor DEC-205 in combination with toll-like receptor agonists. Society for Immunotherapy of Cancer Annual Meeting. 2012.

\section{Diefenbach 2008 \{published data only\}}

Diefenbach CSM, Gnjatic S, Sabbatini P, Aghajanian C, Hensley ML, Spriggs DR, et al. Safety and immunogenicity study of NY-ESO-1b peptide and montanide ISA-51 vaccination of patients with epithelial ovarian cancer in high-risk first remission. Clinical Cancer Research 2008;14(9):2740-8.

\section{Dijkgraaf 2015 \{published data only\}}

Dijkgraaf EM, Santegoets SJ, Reyners AK, Goedemans R, Nijman HW, van Poelgeest MI, et al. A phase $1 / 2$ study combining gemcitabine, Pegintron and $\mathrm{p} 53$ SLP vaccine in patients with platinum-resistant ovarian cancer. Oncotarget 2015;6:32228-43. [PUBMED: 26334096]

\section{Ehlen 2005 \{published data only\}}

Ehlen TG, Hoskins PJ, Miller D, Whiteside TL, Nicodemus CF, Schultes BC, et al. A pilot phase 2 study of oregovomab murine monoclonal antibody to CA125 as an immunotherapeutic agent for recurrent ovarian cancer. International Journal of Gynecological Cancer 2005;15(6):1023-34.

\section{Freedman 1998 \{published data only\}}

* Freedman RS, Kudelka AP, Verschraegen CF, Edwards CL, Tomasovic B, Kaplan A, et al. Therapeutic anti-cancer vaccine: a randomized double blind dose comparison study of sialyl Tn-KLH with Detox-B SE adjuvant for active specific immunotherapy of ovarian cancer (OC). American Society of Clinical Oncology Annual Meeting. 1998.

Termrungruanglert W, Kudelka AP, Verschraegen CF, Freedman RS, Edwards CL, Tomasovic B, et al. Therapeutic anticancer vaccine: a randomized double blind dose comparison study of sialyl TN-K with detox-B SE adjuvant for active specific immunotherapy of ovarian cancer (OC). American Society of Clinical Oncology Annual Meeting. 1996.

\section{Galanis 2010 \{published data only\}}

Galanis E, Hartmann L, Cliby WA, Long HJ, Peethambaram PP, Barrette BA, et al. Phase I trial of intraperitoneal administration of an oncolytic measles virus strain engineered to express carcinoembryonic antigen for recurrent ovarian cancer. Cancer Research 2010;70(3):875-82.

\section{Goh 2013 \{published data only\}}

Goh J, CAN-003 Study Team, Gargosky SE, Gray H. Clinical study of autologous dendritic cell therapy targeting mucin 1 for treatment of ovarian cancer patients in first remission. European Cancer Congress. 2013.

\section{Gordon 2004 \{published data only\}}

Gordon AN, Schultes BC, Gallion H, Edwards R, Whiteside TL, Cermak JM, et al. CA125- and tumor-specific T-cell responses correlate with prolonged survival in oregovomab-treated recurrent ovarian cancer patients. Gynecologic Oncology 2004;94(2):340-51.

\section{Gray 2016 \{published data only\}}

Gray HJ, Benigno B, Berek J, Chang J, Mason J, Mileshkin L, et al. Progression-free and overall survival in ovarian cancer patients treated with $\mathrm{CVac}$, a mucin 1 dendritic cell therapy in a randomized phase 2 trial. Journal for Immunotherapy of Cancer 2016;4:34. [PUBMED: 27330807]

Gribben 2005 \{published data only\}

Gribben JG, Ryan DP, Urban RG, Hedley ML, Beach K, Nealon P, et al. Unexpected association between induction of immunity to the universal tumor antigen CYP1B1 and response to next therapy. Clinical Cancer Research 2005;11(12):4430-6.

\section{Gulley 2008 \{published data only\}}

Gulley JL, Arlen PM, Tsang KY, Yokokawa J, Palena C, Poole DJ, et al. Pilot study of vaccination with recombinant CEA-MUC-1TRICOM poxviral-based vaccines in patients with metastatic carcinoma. Clinical Cancer Research 2008;14:3060-9.

\section{Heiss 2010 \{published data only\}}

Heiss MM, Maruwa P, Koralewski P, Kutarska E, Kolesnik OO, Ivanchenko VV, et al. The trifunctional antibody catumaxomab for the treatment of malignant ascites due to epithelial cancer: results of a prospective randomized phase II/III trial. International Journal of Cancer 2010;127:2209-21.

\section{Imhof 2013 \{published data only\}}

Imhoff M, Lipovac M, Angleitner-Boubenizek L, Barta J, Gomez I, Hrdina A, et al. Double-loaded mature dendritic cell (DC) therapy for non-HLA-restricted patients with advanced ovarian cancer: final results of a clinical phase I study. American Society of Clinical Oncolocy Annual Meeting. 2013.

Kaumaya 2009 \{published data only\}

Kaumaya PTP, Foy KC, Garrett J, Rawale SV, Vicari D, Thurmond JM, et al. Phase I active immunotherapy with combination of two chimeric, human epidermal growth factor receptor 2, b-cell epitopes fused to a promiscuous T-cell epitope in patients with metastatic and/or recurrent solid tumors. Journal of Clinical Oncology 2009;27(31):5270-7.

\section{Kawano 2014 \{published data only\}}

Kawano K, Tsuda N, Matsueda S, Sasada T, Watanabe N, Ushijima K, et al. Feasibility study of personalized peptide vaccination for recurrent ovarian cancer patients. Immunopharmacology Immunotoxicology 2014;36:224-36. [PUBMED: 24773550]

\section{Kobayashi 2014 \{published data only\}}

Kobayashi M, Chiba A, Izawa H, Yanagida E, Okamoto M, Shimodaira $S$, et al. The feasibility and clinical effects of dendritic cell-based immunotherapy targeting synthesized peptides for recurrent ovarian cancer. Journal of Ovarian Research 2014;7:48. [PUBMED: 25298213]

\section{Le 2012 \{published data only\}}

Le DT, Brockstedt DG, Nir-Paz R, Hampl J, Mathur S, Nemunaitis J, et al. A live-attenuated listeria vaccine (ANZ-100) and a live-attenuated listeria vaccine expressing mesothelin (CRS-207) for advanced cancers: phase I studies of safety and immune induction. Clinical Cancer Research 2012;18(3):858-68. 
Leffers 2009a \{published data only\}

* Leffers N, Lambeck AJ, Gooden MJ, Hoogeboom BN, Wolf R, Hamming IE, et al. Immunization with a P53 synthetic long peptide vaccine induces $P 53$-specific immune responses in ovarian cancer patients, a phase II trial. International Journal of Cancer 2009; May 28:[Epub ahead of print].

Leffers N, Vermeij R, Hoogeboom BN, Schultze UR, Wolf R, Hamming IE, et al. Long-term clinical and immunological effects of p53-SLP vaccine in patients with ovarian cancer. International Journal of Cancer 2012;130:105-12.

\section{Lennerz 2014 \{published data only\}}

Lennerz V, Gross S, Gallerani E, Sessa C, Mach N, Boehm S, et al. Immunologic response to the survivin-derived multi-epitope vaccine EMD640744 in patients with advanced solid tumors. Cancer Immunology Immunotherapy 2014;63:381-94. [PUBMED: 24487961]

\section{Letsch 2011 \{published data only\}}

Letsch A, Scheibenbogen C, Asemissen AM, Zimmermann K, Knodler M, Völker-Call M, et al. Wilms tumor protein (WT) 1 peptide vaccination in patients with WT1 expressing solid tumors demonstrates clinical and immunological efficacy. Onkologie 2011;34(Suppl 6):194.

\section{Ma 2002 \{published data only\}}

Ma J, Zhou L, Wang D. Functional mimicry of an anti-idiotypic antibody to nominal antigen on cellular response. Japanese Journal of Cancer Research 2002;93(1):78-84.

\section{MacLean 1992 \{published data only\}}

MacLean GD, Bowen-Yacyshyn MB, Samuel J, Meikle A, Stuart G, Nation J, et al. Active immunization of human ovarian cancer patients against a common carcinoma (Thomsen-Friedenreich) determinant using a synthetic carbohydrate antigen. Journal of Immunotherapy 1992;11(4):292-305.

\section{MacLean 1996 \{published data only\}}

MacLean GD, Reddish MA, Koganty RR, Longenecker BM. Antibodies against mucin-associated sialyl-Tn epitopes correlate with survival of metastatic adenocarcinoma patients undergoing active specific immunotherapy with synthetic STn vaccine. Journal of Immunotherapy With Emphasis on Tumor Immunology 1996;19(1):59-68.

\section{Method 2002 \{published data only\}}

Method M, Gordon A, Finkler N, Fingert H, Nicodemus CF, Whiteside TL, et al. Randomized evaluation of 3 treatment schedules to optimize clinical activity of OvaRex Mab B43.13 (OV) in patients (pts) with epithelial ovarian cancer (EOC). American Society of Clinical Oncology Annual Meeting. 2002.

\section{Möbus 2003 \{published data only\}}

Mobus VJ, Baum RP, Bolle M, Kreienberg R, Noujaim AA, Schultes $B C$, et al. Immune responses to murine monoclonal antibody-B43.13 correlate with prolonged survival of women with recurrent ovarian cancer. American Journal of Obstetrics and Gynecology 2003;189(1):28-36.

\section{Mohebtash 2011 \{published data only\}}

Mohebtash M, Madan R, Tsang K, Arlen Ph, Pazdur M, Jones J, et al. Clinical outcomes following immunotherapy with a MUC1/ CEA vaccine in patients with metastatic breast and ovarian cancer. American Association of Cancer Research Annual Meeting. 2009.

* Mohebtash M, Tsang KY, Huen NY, Poole DJ, Jochems C, Jones J, et al. A pilot study of MUC-1/CEA/TRICOM poxviralbased vaccine in patients with metastatic breast and ovarian cancer. Clinical Cancer Research 2011;17(22):7164-73.

\section{Morse 2011 \{published data only\}}

Morse MA, Secord AA, Blackwell K, Hobeika AM, Sinnathamby G, Osada T, et al. MHC class I-presented tumor antigens identified in ovarian cancer by immunoproteomic analysis are targets for T-cell responses against breast and ovarian cancer. Clinical Cancer Research 2011;17(10):3408-19.

\section{Nicholson 2004 \{published data only\}}

Nicholson S, Bomphray CC, Thomas H, Mclndoe A, Barton D, Gore M, et al. A phase I trial of idiotypic vaccination with HMFG1 in ovarian cancer. Cancer Immunology, Immunotherapy 2004;53(9):809-16.

\section{Nishikawa 2006 \{published data only\}}

Nishikawa H, Qian F, Tsuji T, Ritter G, Old LJ, Gnjatic S, et al. Influence of CD4(+)CD25(+) regulatory T cells on low/highavidity CD4(+) T cells following peptide vaccination. Journal of Immunology 2006;176(10):6340-6.

\section{Noujaim 2001 \{published data only\}}

Noujaim AA, Schultes BC, Baum RP, Madiyalakan R. Induction of CA125-specific $B$ and $T$ cell responses in patients injected with MAb-B43.13 - evidence for antibody-mediated antigenprocessing and presentation of CA125 in vivo. Cancer Biotherapy \& Radiopharmaceuticals 2001;16(3):187-203.

\section{O'Cearbhaill 2016 \{published data only\}}

O'Cearbhaill RE, Ragupathi G, Zhu J, Wan Q, Mironov S, Yang G, et al. A phase I study of unimolecular pentavalent (GloboH-GM2-sTn-TF-Tn) immunization of patients with epithelial ovarian, fallopian tube, or peritoneal cancer in first remission. Cancers 2016;8:46. [PUBMED: 27110823]

\section{Odunsi 2007 \{published data only\}}

Odunsi K, Qian F, Matsuzaki J, Mhawech-Fauceglia P, Andrews C, Hoffman EW, et al. Vaccination with an NY-ESO-1 peptide of HLA class I/II specificities induces integrated humoral and $T$ cell responses in ovarian cancer. Proceedings of the National Academy of Sciences of the United States of America 2007;104(31):12837-42.

\section{Odunsi 2012 \{published data only\}}

* Odunsi K, Matsuzaki J, Karbach J, Neumann A, MhawechFauceglia P, Miller M, et al. Efficacy of vaccination with recombinant vaccinia and fowlpox vectors expressing NYESO-1 antigen in ovarian cancer and melanoma patients. PNAS 2012;109(15):5797-802. 
Odunsi K, Rodabaugh K, Lele S, Old LJ, Matsuzaki J, Qian F, et al. Diversified prime and boost vaccination using recombinant vaccinia and fowlpox expressing NY-ESO-1 efficiently induces antibody, CD4+, and CD8+ antitumor immune responses in patients with ovarian cancer. Society of Gynecologic Oncologists Annual Meeting on Women's Cancer. 2007.

\section{Odunsi 2014 \{published data only\}}

Odunsi K, Matsuzaki J, James SR, Mhawech-Fauceglia P, Tsuji T, Miller A, et al. Epigenetic potentiation of NY-ESO-1 vaccine therapy in human ovarian cancer. Cancer Immunology, Immunotherapy 2014;2:37-49. [24535937]

\section{Ohno 2009 \{published data only\}}

Dohi S, Ohno S, Ohno Y, Takakura M, Kyo S, Soma GI, et al. WT1 peptide vaccine stabilized intractable ovarian cancer patient for one year: a case report. Anticancer Research 2001;31:2441-6.

* Ohno S, Kyo S, Myojo S, Dohi S, Ishizaki J, Miyamoto KI, et al. Wilms' tumor 1 (WT1) peptide immunotherapy for gynecological malignancy. Anticancer Research 2009;29:4779-84.

\section{Peethambaram 2009 \{published data only\}}

Peethambaram PP, Melisko ME, Rinn KJ, Alberts SR, Provost NM, Jones LA, et al. A phase I trial of immunotherapy with Lapuleucel-T (APC8024) in patients with refractory metastatic tumors that express Her-2/neu. Clinical Cancer Research 2009;15(18):5937-44.

\section{Pfisterer 2006 \{published data only\}}

Pfisterer J, du Bois A, Sehouli J, Loibl S, Reinartz S, Reuss A, et al. The anti-idiotypic antibody abagovomab in patients with recurrent ovarian cancer. A phase I trial of the AGO-OVAR. Annals of Oncology 2006;17(10):1568-77.

\section{Rahma 2012 \{published data only\}}

Herrin V, Achtar M, Steinberg S, Whiteside TL, Wieckowsk E, Czystowska $\mathrm{M}$, et al. A randomized phase II p53 vaccine trial comparing subcutaneous direct administration with intravenous peptide-pulsed dendritic cells in high risk ovarian cancer patients. American Society of Clinical Oncology Annual Meeting. 2007.

Herrin V, Behrens RJ, Achtar M, Monahan B, Bernstein S, Brent-Steele T, et al. Wild-type $\mathrm{p} 53$ peptide vaccine can generate a specific immune response in low burden ovarian adenocarcinom. American Society of Clinical Oncology Annual Meeting. 2003.

* Rahma OE, Ashtar E, Czystowska M, Szajnik ME, Wieckowski E, Bernstein S, et al. A gynecologic oncology group phase II trial of two 553 peptide vaccine approaches: subcutaneous injection and intravenous pulsed dendritic cells in high recurrence risk ovarian cancer patients. Cancer Immunology, Immunotherapy 2012;61:374-84.

\section{Reinartz 2004 \{published data only\}}

* Reinartz S, Kohler S, Schlebusch H, Krista K, Giffels P, Renke $\mathrm{K}$, et al. Vaccination of patients with advanced ovarian carcinoma with the anti-idiotype ACA125: immunological response and survival (phase Ib/II). Clinical Cancer Research 2004;10(5):1580-7.
Wagner U, Kohler S, Reinartz S, Giffels P, Huober J, Renke K et al. Immunological consolidation of ovarian carcinoma recurrences with monoclonal anti-idiotype antibody ACA125: immune responses and survival in palliative treatment. Clinical Cancer Research 2001;7(5):1154-62.

Sabbatini 2000 \{published data only\}

Sabbatini PJ, Kudryashov V, Ragupathi G, Danishefsky SJ, Livingston PO, Bornmann W, et al. Immunization of ovarian cancer patients with a synthetic Lewis(y)-protein conjugate vaccine: a phase 1 trial. Clinical Cancer Research 2000;87(1):79-85.

\section{Sabbatini 2006 \{published data only\}}

Sabbatini P, Dupont J, Aghajanian C, Derosa F, Poynor E, Anderson S, et al. Phase I study of abagovomab in patients with epithelial ovarian, fallopian tube, or primary peritoneal cancer. Clinical Cancer Research 2006;12(18):5503-10.

\section{Sabbatini 2007 \{published data only\}}

Sabbatini PJ, Ragupathi G, Hood C, Aghajanian CA, Juretzka M, lasonos $A$, et al. Pilot study of a heptavalent vaccine-keyhole limpet hemocyanin conjugate plus QS21 in patients with epithelial ovarian, fallopian tube, or peritoneal cancer. Clinical Cancer Research 2007;13:4170-7.

\section{Sabbatini 2012 \{published data only\}}

Sabbatini P, Tsuji T, Ferran L, Ritter E, Sedrak C, Tuballes K, et al. Phase I trial of overlapping long peptides from a tumor selfantigen and poly-ICLC shows rapid induction of integrated immune response in ovarian cancer patients. Clinical Cancer Research 2012;18(23):6497-508.

\section{Sabbatini 2013 \{published data only\}}

Sabbatini P, Harther P, Scambia G, Sehouli J, Meier W, Wimberger $P$, et al. Abagovomab as maintenance therapy in patients with epithelial ovarian cancer: a phase III trial of the AGO OVAR, COGI, GINECO and GEICO - the MIMOSA study. Journal of Clinical Oncology 2013;31(12):1554-61.

\section{Sabbatini 2017 \{published data only\}}

* Sabbatini P, Chen L, Lucci J, Behbakht K, Spirtos N, Muller C. OPT-821 with or without vaccine therapy in treating patients with ovarian epithelial cancer, fallopian tube cancer, or peritoneal cancer in second or third complete remission. clinicaltrials.gov 2017. [NCT00857545]

\section{Sandmaier 1999 \{published data only\}}

Sandmaier BM, Oparin DV, Holmberg LA, Reddish MA, MacLean GD, Longenecker BM. Evidence of a cellular immune response against sialyl-Tn in breast and ovarian cancer patients after high-dose chemotherapy, stem cell rescue, and immunization with Theratope STn-KLH cancer vaccine. Journal of Immunotherapy 1999;22(1):54-66.

\section{Schultes 1998 \{published data only\}}

Schultes B, Yang R, Agopsowicz K, Kuzma M, Dharampaul S, Baum $R$, et al. Anti-idiotype induction therapy for ovarian cancer: immune responses in patients injected with OvaRexMab-B43.13. American Society of Clinical Oncology Annual Meeting. 1999. 
* Schultes BC, Baum RP, Niesen A, Noujaim AA, Madiyalakan R. Anti-idiotype induction therapy: anti-CA125 antibodies (Ab3) mediated tumor killing in patients treated with Ovarex mAb B43.13 (Ab1). Cancer Immunology, Immunotherapy 1998;46(4):201-12.

\section{Ströhlein 2009 \{published data only\}}

Ströhlein MA, Siegel R, Jäger M, Lindhofer H, Jauch KW, Heiss MM. Induction of anti-tumor immunity by trifunctional antibodies in patients with peritoneal carcinomatosis. Journal of Experimental \& Clinical Cancer Research 2009;28:18.

\section{Suzuki 2016 \{published data only\}}

Suzuki S, Sakata J, Utsumi F, Sekiya R, Kajiyama H, Shibata K, et al. Efficacy of glypican-3-derived peptide vaccine therapy on the survival of patients with refractory ovarian clear cell carcinoma. Oncoimmunology 2016;5(11):1238542. [PUBMED: 27999758]

\section{Takeoka 2017 \{published data only\}}

Takeoka T, Nagase H, Kurose K, Ohue Y, Yamasaki M, Takiguchi S, et al. NY-ESO-1 protein cancer vaccine with Poly-ICLC and OK-432: rapid and strong induction of NY-ESO-1-specific immune responses by Poly-ICLC. Journal of Immunotherapy 2017;40:140-7. [PUBMED: 28338507]

\section{Takeuchi 2013 \{published data only\}}

Takeuchi S, Shoji T, Kagabu M, Honda T, Miura F, Omi H, et al. A phase I/II study of multiple peptides cocktail vaccine for advanced/recurrent ovarian cancer. American Society of Clinical Oncology Annual Meeting. 2013.

\section{Tsuda 2004 \{published data only\}}

Tsuda N, Mochizuki K, Harada M, Sukehiro A, Kawano K, Yamada A, et al. Vaccination with predesignated or evidencebased peptides for patients with recurrent gynecologic cancers. Journal of Immunotherapy 2004;27(1):60-72.

\section{van Zanten-Przybysz 2002 \{published data only\}}

van Zanten-Przybysz I, Molthoff C, Gebbinck JK, von MensdorffPouilly S, Verstraeten R, Kenemans P, et al. Cellular and humoral responses after multiple injections of unconjugated chimeric monoclonal antibody MOv18 in ovarian cancer patients: a pilot study. Journal of Cancer Research and Clinical Oncology 2002;128(9):484-92.

\section{Vermeij 2012 \{published data only\}}

Vermeij R, Leffers N, Hoogeboom BN, Hamming LE, Wolf R, Reyners AKL, et al. Potentiation of a p53-SLP vaccine by cyclophosphamide in ovarian cancer: a single-arm phase II study. International Journal of Cancer 2012;131:E670-80.

\section{Wagner 1993 \{published data only\}}

* Wagner U. Antitumor antibodies for immunotherapy of ovarian carcinomas. Hybridoma 1993;12(5):521-8.

Wagner U, Reinsberg J, Schmidt S, Mallmann P, Schmolling J, Schultes B, et al. Monoclonal antibodies and idiotypic network activation for ovarian carcinoma. Cell Biophysics 1994;24-25:237-42.

\section{References to studies excluded from this review}

Anderson 2000 \{published data only\}

Anderson BW, Kudelka AP, Honda T, Pollack MS, Gershenson DM, Gillogly MA, et al. Induction of determinant spreading and of Th1 responses by in vitro stimulation with HER-2 peptides. Cancer Immunology, Immunotherapy 2000;49(9):459-68.

Baek 2015 \{published data only\}

Baek S, Kim YM, Kim SB, Kim CS, Kwon SW, Kim Y. Therapeutic DC vaccination with IL-2 as a consolidation therapy for ovarian cancer patients: a phase I/II trial. Cellular \& Molecular Immunology 2015;12:87-95. [PUBMED: 24976269]

Bapsy 2014 \{published data only\}

Bapsy PP, Sharan B, Kumar C, Das RP, Rangarajan B, Jain M. Open-label, multi-center, non-randomized, single-arm study to evaluate the safety and efficacy of dendritic cell immunotherapy in patients with refractory solid malignancies, on supportive care. Cytotherapy 2014;16(2):234-44. [PUBMED: 24438902]

\section{Bender 2007 \{published data only\}}

Bender A, Karbach J, Neumann A, Jager D, Al-Batran SE, Atmaca A, et al. LUD 00-009: phase 1 study of intensive course immunization with NY-ESO-1 peptides in HLA-A2 positive patients with NY-ESO-1-expressing cancer. Cancer Immunology, Immunotherapy 2007;7:16.

Bernal 2012 \{published data only\}

Bernal SD, Ona ET, Riego-Javier E, de Villa R, Cristal-Luna GR, Laguatan JB, et al. Anticancer immune reactivity and longterm survival after treatment of metastatic ovarian cancer with dendritic cells. Oncology Letters 2012;3:66-74.

\section{Carbone 2005 \{published data only\}}

Carbone DP, Ciernik IF, Kelley MJ, Smith MC, Nadaf S, Kavanaugh D, et al. Immunization with mutant p53and K-ras-derived peptides in cancer patients: immune response and clinical outcome. Journal of Clinical Oncology 2005;23(22):5099-107.

\section{Chiang 2013 \{published data only\}}

Chiang CL, Kandalaft LE, Tanyi J, Hagemann AR, Motz GT, Svoronos N. A dendritic cell vaccine pulsed with autologous hypochlorous acid-oxidized ovarian cancer lysate primes effective broad antitumor immunity: from bench to bedside. Clinical Cancer Research 2013;19(17):4801-15. [PUBMED: 23838316]

\section{Coosemans 2013 \{published data only\}}

Coosemans A, Vanderstraeten A, Tuyaerts S, Verschuere T, Moerman P, Berneman Z. Immunological response after WT1 mRNA-loaded dendritic cell immunotherapy in ovarian carcinoma and carcinosarcoma. Anticancer Research 2013;33(9):3855-9. [PUBMED: 24023319]

\section{Dhodapkar 2014 \{published data only\}}

Dhodapkar MV, Sznol M, Zhao B, Wang D, Carvajal RD, Keohan ML, et al. Induction of antigen-specific immunity with 
a vaccine targeting NY-ESO-1 to the dendritic cell receptor DEC-205. Science Translational Medicine 2014;6(232):51. [PUBMED: 24739759]

\section{Disis 1999 \{published data only\}}

Disis ML, Grabstein KH, Sleath PR, Cheever MA. Generation of immunity to the HER-2/neu oncogenic protein in patients with breast and ovarian cancer using a peptide-based vaccine. Clinical Cancer Research 1999;5(6):1289-97.

\section{Disis 2000 \{published data only\}}

Disis ML, Schiffman K, Gooley TA, McNeel DG, Rinn K, Knutson KL. Delayed-type hypersensitivity response is a predictor of peripheral blood T-cell immunity after HER-2/ neu peptide immunization. Clinical Cancer Research 2000;6(4):1347-50

\section{Disis 2002 \{published data only\}}

Disis ML, Gooley TA, Rinn K, Davis D, Piepkorn M, Cheever MA, et al. Generation of T-cell immunity to the HER-2/neu protein after active immunization with HER-2/neu peptide-based vaccines. Journal of Clinical Oncology 2002;20(11):2624-32.

\section{Disis 2002a \{published data only\}}

Disis ML, Rinn K, Knutson KL, Davis D, Caron D, dela Rosa C, et al. Flt3 ligand as a vaccine adjuvant in association with HER-2/neu peptide-based vaccines in patients with HER-2/neuoverexpressing cancers. Blood 2002;99(8):2845-50.

\section{Disis 2004 \{published data only\}}

Disis ML, Goodell V, Schiffman K, Knutson KL. Humoral epitopespreading following immunization with a HER-2/neu peptide based vaccine in cancer patients. Journal of Clinical Immunology 2004;24(5):571-8.

\section{Disis 2004a \{published data only\}}

Disis ML, Schiffman K, Guthrie K, Salazar LG, Knutson KL, Goodell V, et al. Effect of dose on immune response in patients vaccinated with an her-2/neu intracellular domain protein-based vaccine. Journal of Clinical Oncology 2004;22(10):1916-25.

\section{Galanis 2013 \{published data only\}}

Galanis E, Atherton P, Dowdy S, Cliby W, Haluska P, Long H, et al. Intraperitoneal (IP) administration of an oncolytic measles virus (MV) strain expressing the sodium iodine symporter gene in patients (pts) with advanced ovarian cancer (ovca). American Society of Gene \& Cell Therapy (ASGCT) Annual Meeting. 2013.

\section{Haakenstad 2012 \{published data only\}}

* Haakenstad H, Suso EMI, Rasmussen AM, Larsen SS, Dueland S, Lilleby W, et al. Clinical use of fast DCs transfected with hTERT and Survivin mRNA - an effective and simplified cancer vaccine approach. European Group for Blood and Marrow Transplantation Annual Meeting. 2012.

Kvalheim G, Suso E, Rasmussen A, Honnashagen T, Dueland S, Gaudernack G. Fast DCs transfected with hTERT and Survivin mRNA - a novel, effective and simplified cancer vaccine approach. European Group for Blood and Marrow Transplantation Annual Meeting. 2011.

\section{Hasumi 2011 \{published data only\}}

Hasumi K, Aoki Y, Watanabe R, Hankey KG, Mann DL. Therapeutic response in patients with advanced malignancies treated with combined dendritic cell-activated T cell based immunotherapy and intensity-modulated radiotherapy. Cancers 2011;3:2223-42.

\section{Hernando 2002 \{published data only\}}

Hernando JJ, Park TW, Kubler K, Offergeld R, Schlebusch H, Bauknecht T. Vaccination with autologous tumour antigenpulsed dendritic cells in advanced gynaecological malignancies: clinical and immunological evaluation of a phase I trial. Cancer Immunology, Immunotherapy 2002;51(1):45-52.

Hernando 2007 \{published data only\}

Hernando JJ, Park T-W, Fischer H-P, Zivanovic O, Braun M, Polcher $\mathrm{M}$, et al. Vaccination with dendritic cells transfected with mRNA-encoded folate-receptor-(alpha) for relapsed metastatic ovarian cancer. Lancet Oncology 2007;8(5):451-4.

Holmberg 2000 \{published data only\}

Holmberg LA, Oparin DV, Gooley T, Lilleby K, Bensinger W, Reddish MA, et al. Clinical outcome of breast and ovarian cancer patients treated with high-dose chemotherapy, autologous stem cell rescue and THERATOPE STn-KLH cancer vaccine. Bone Marrow Transplant 2000;25(12):1233-41.

\section{Hui 1997 \{published data only\}}

Hui KM, Ang PT, Huang L, Tay SK. Phase I study of immunotherapy of cutaneous metastases of human carcinoma using allogeneic and xenogeneic MHC DNA-liposome complexes. Gene Therapy 1997;4(8):783-90.

\section{Jackson 2017 \{published data only\}}

Jackson D, Byrd K, Vreeland T, Hale D, Herbert G, Greene JM, et al. Interim analysis of a phase I/IIa trial assessing E39+GM-CSF, a folate binding protein vaccine, to prevent recurrence in ovarian and endometrial cancer patients. Oncotarget 2017;8:15912-23.

\section{Jager 2006 \{published data only\}}

Jager E, Karbach J, Gnjatic S, Neumann A, Bender A, Valmori D, et al. Recombinant vaccinia/fowlpox NY-ESO-1 vaccines induce both humoral and cellular NY-ESO-1-specific immune responses in cancer patients. Proceedings of the National Academy of Sciences of the United States of America 2006;103(39):14453-8.

\section{Kandalaft 2010 \{published data only\}}

Coukos G, Powell D, Kandalaft L, Smith L, Chu C, Rubin S, et al. Autologous whole-tumor antigen combinatorial immunotherapy for recurrent ovarian cancer. Gynecologic Oncology 2010;116:s130.

* Kandalaft LE, Powell DJ, Smith L, Adams S, Liao J, Hageman A, et al. Autologous whole-tumor anitgen combinatorial immunotherapy for recurrent ovarian cancer. Journal of Immunotherapy 2010;33(8):878.

\section{Karbach 2010 \{published data only\}}

Karbach J, Gnjatic S, Bender A, Neumann A, Weidmann E, Yuan J, et al. Tumor-reactive CD8+ T-cell responses after vaccination with NY-ESO-1 peptide, CpG 7909 and Montanide 
ISA-51: association with survival. International Journal of Cancer 2010;126:909-18.

\section{Kato 2010 \{published data only\}}

Kato Y. WT1 peptide pulsed dendritic cell therapy with activated T lymphocytes therapy for advanced cancers. Gan To Kagaku Ryoho 2010;37(12):2240-2.

\section{Khranovska 2011 \{published data only\}}

Khranovska NM, Svyntsytsky VS, Potebnya GP, Vorobyova LI, Skachkova OV, Tsyp NP, et al. New dendritic cell vaccine therapy approach - randomized phase I/II study in III-IV stage ovarian cancer patients. European Multidisciplinary Cancer Conference (ECCO ESMO ESTRO). 2011.

\section{Knutson 2001 \{published data only\}}

Knutson KL, Schiffman K, Disis ML. Immunization with a HER-2/ neu helper peptide vaccine generates HER-2/neu CD8 T-cell immunity in cancer patients. Journal of Clinical Investigation 2001;107(4):477-84.

\section{Knutson 2002 \{published data only\}}

Knutson KL, Schiffman K, Cheever MA, Disis ML. Immunization of cancer patients with a HER-2/neu, HLA-A2 peptide, p369-377, results in short-lived peptide-specific immunity. Clinical Cancer Research 2002;8(5):1014-8.

\section{Letsch 2008 \{published data only\}}

Letsch A, Asemissen AM, Zimmermann K, Bauer S, Stather D, Völker-Call M, et al. Different quality of T cell responses to WT1 peptide vaccination in patients with AML/MDS and patients with solid tumors. Journal of Immunotherapy. 2008; Vol. 31:943-4.

\section{Loveland 2006 \{published data only\}}

Loveland BE, Zhao A, White S, Gan H, Hamilton K, Xing PX, et al. Mannan-MUC1-pulsed dendritic cell immunotherapy: a phase I trial in patients with adenocarcinoma. Clinical Cancer Research 2006;12(3 Pt 1):869-77.

\section{Manjunath 2012 \{published data only\}}

Manjunath SR, Ramanan G, Dedeepiya VD, Terunuma H, Deng X, Baskar S, et al. Autologous immune enhancement therapy in recurrent ovarian cancer with metastases: a case report. Case Reports in Oncology 2012;5:114-8.

\section{Marshall 2005 \{published data only\}}

Marshall JL, Gulley JL, Arlen PM, Beetham PK, Tsang KY, Slack $R$, et al. Phase I study of sequential vaccinations with fowlpox-CEA(6D)-TRICOM alone and sequentially with vacciniaCEA(6D)-TRICOM, with and without granulocyte-macrophage colony-stimulating factor, in patients with carcinoembryonic antigen-expressing carcinomas. Journal of Clinical Oncology 2005;23:720-31.

\section{Matsuzaki 2014 \{published data only\}}

Matsuzaki J, Tsuji T, Luescher I, Old LJ, Shrikant P, Gnjatic S. Nonclassical antigen-processing pathways are required for $\mathrm{MHC}$ class II-restricted direct tumor recognition by NY-ESO-1-specific CD4(+) T cells. Cancer Immunology Research 2014;2(4):341-50. [PUBMED: 24764581]

\section{Miotti 1999 \{published data only\}}

Miotti S, Negri DR, Valota O, Calabrese M, Bolhuis RL, Gratama JW, et al. Level of anti-mouse-antibody response induced by bi-specific monoclonal antibody OC/TR in ovariancarcinoma patients is associated with longer survival. International Journal of Cancer 1999;84(1):62-8.

\section{Morera 2017 \{published data only\}}

Morera Y, Sánchez J, Bequet-Romero M, Selman-Housein KH, de la Torre A, Hernández-Bernal F. Specific humoral and cellular immune responses in cancer patients undergoing chronic immunization with a VEGF-based therapeutic vaccine. Vaccine 2017;35:3582-90. [PUBMED: 28536029]

\section{Morse 1999 \{published data only\}}

Morse MA, Deng Y, Coleman D, Hull S, Kitrell-Fisher E, Nair S, et al. A Phase I study of active immunotherapy with carcinoembryonic antigen peptide (CAP-1)-pulsed, autologous human cultured dendritic cells in patients with metastatic malignancies expressing carcinoembryonic antigen. Clinical Cancer Research 1999;5(6):1331-8.

\section{Morse 2003 \{published data only\}}

Morse MA, Clay TM, Colling K, Hobeika A, Grabstein K, Cheever MA, et al. Her2 dendritic cell vaccines. Clinical Breast Cancer 2003;3(Suppl 4):S164-72.

\section{Morse 2011a \{published data only\}}

Morse MA, Chapman R, Powerdly J, Blackwell K, Keler T, Green J, et al. Phase I study utilizing a novel antigen-presenting cell-targeted vaccine with toll-like receptor stimulation to induce immunity to self-antigens in cancer patients. Clinical Cancer Research 2011;17(14):4844-53.

\section{Murray 2002 \{published data only\}}

Murray JL, Gillogly ME, Przepiorka D, Brewer H, Ibrahim NK, Booser DJ, et al. Toxicity, immunogenicity, and induction of E75-specific tumor-lytic CTLs by HER-2 peptide E75 (369-377) combined with granulocyte macrophage colony-stimulating factor in HLA-A2+ patients with metastatic breast and ovarian cancer. Clinical Cancer Research 2002;8(11):3407-18.

\section{Oh 2016 \{published data only\}}

Oh J, Barve M, Matthews CM, Koon EC, Heffernan TP, Fine B. Phase II study of Vigi ${ }^{\circledR}$ DNA engineered immunotherapy as maintenance in advanced stage ovarian cancer. Gynaecologic Oncology 2016;143(3):504-10. [27678295]

\section{Parkhurst 2004 \{published data only\}}

Parkhurst MR, Riley JP, Igarashi T, Li Y, Robbins PF, Rosenberg SA. Immunization of patients with the hTERT:540-548 peptide induces peptide-reactive T lymphocytes that do not recognize tumors endogenously expressing telomerase. Clinical Cancer Research 2004;10(14):4688-98.

\section{Reddish 1996 \{published data only\}}

Reddish MA, MacLean GD, Poppema S, Berg A, Longenecker BM. Pre-immunotherapy serum CA27.29 (MUC-1) mucin level and CD69+ lymphocytes correlate with effects of Theratope sialyl$\mathrm{Tn}-\mathrm{KLH}$ cancer vaccine in active specific immunotherapy. Cancer Immunology, Immunotherapy 1996;42(5):303-9. 
Salazar 2006 \{published data only\}

Salazar LG, Murray JL, Disis ML, Cheever M. A phase I vaccine trial of a HER-2/neu peptide incorporated into PLG microspheres in patients with advanced stage HER2-expressing cancers. ASCO Annual Meeting. 2006.

\section{Schiffman 2002 \{published data only\}}

Schiffman K, Rinn K, Disis ML. Delayed type hypersensitivity response to recall antigens does not accurately reflect immune competence in advanced stage breast cancer patients. Breast Cancer Research and Treatment 2002;74(1):17-23.

Tsuji 2013 \{published data only\}

Tsuji T, Sabbatini P, Jungbluth AA, Ritter E, Pan L, Ritter G, et al. Effect of Montanide and poly-ICLC adjuvant on human self/ tumor antigen-specific CD4+ T cells in phase I overlapping long peptide vaccine trial. Cancer Immunology Research 2013;1:340-50. [DOI: 10.1158/2326-6066.CIR-13-0089]

\section{Yacyshyn 1995 \{published data only\}}

Yacyshyn MB, Poppema S, Berg A, MacLean GD, Reddish MA, Meikle A, et al. CD69+ and HLA-DR+ activation antigens on peripheral blood lymphocyte populations in metastatic breast and ovarian cancer patients: correlations with survival following active specific immunotherapy. International Journal of Cancer 1995;61(4):470-4.

\section{Zaks 1998 \{published data only\}}

Zaks TZ, Rosenberg SA. Immunization with a peptide epitope (p369-377) from HER-2/neu leads to peptide-specific cytotoxic T lymphocytes that fail to recognize HER-2/neu+tumors. Cancer Research 1998;58(21):4902-8.

\section{References to ongoing studies}

\section{NCT00003002 \{unpublished data only\}}

University of Washington. Her-2/Neu vaccine plus GM-CSF in treating patients with stage III or stage IV breast, ovarian, or non-small cell lung cancer. clinicaltrials.gov.

\section{NCT00004604 \{unpublished data only\}}

Duke University. Biological therapy in treating patients with metastatic cancer. clinicaltrials.gov.

\section{NCT00006041 \{unpublished data only\}}

Memorial Sloan - Kettering Cancer Center. Vaccine therapy in treating patients with ovarian, fallopian tube, or peritoneal cancer. clinicaltrials.gov.

\section{NCT00381173 \{unpublished data only\}}

Eisai Medical Research Inc. A phase 1 open-label study of the safety and feasibility of ZYC300 administration with cyclophosphamide pre-dosing. clinicaltrials.gov.

\section{NCT00803569 \{unpublished data only\}}

Roswell Park Cancer Institute and National Cancer Institute $(\mathrm{NCI})$. Phase I study of ALVAC(2)-NY-ESO-1(M)/TRICOM in patients with epithelial ovarian, fallopian tube or primary peritoneal carcinoma whose tumors express NY-ESO-1 or LAGE-1 antigen. clinicaltrilas.gov.
NCT01223235 \{unpublished data only\}

Memorial Sloan - Kettering Cancer Center. Polyvalent vaccine-KLH conjugate + Opt-821 given in combination with bevacuzimab. clinicaltrials.gov.

NCT01322802 \{unpublished data only\}

University of Washington. Vaccine therapy in treating patients with stage III-IV or recurrent ovarian cancer. clinicaltrials.gov.

NCT01376505 \{unpublished data only\}

Pravin Kaumaya. Vaccine therapy in treating patients with metastatic solid tumors. clinicaltrials.gov.

NCT01522820 \{unpublished data only\}

Roswell Park Cancer Institute. Vaccine therapy with or without sirolimus in treating patients with NY-ESO-1 expressing solid tumors. clinicaltrials.gov.

\section{NCT01536054 \{unpublished data only\}}

Roswell Park Cancer Institute. Sirolimus and vaccine therapy in treating patients with stage II-IV ovarian epithelial, fallopian tube, or primary peritoneal cavity cancer. clinicaltrials.gov.

\section{NCT01556841 \{unpublished data only\}}

Oxford BioMedica. The activity of TroVax versus placebo in relapsed asymptomatic ovarian cancer (TRIOC). clinicaltrials.gov.

NCT01584115 \{unpublished data only\}

Instituto de Investigacao em Imunologia. Clinical trial of a therapeutic vaccine with NY-ESO-1 in combination with the adjuvant monophosphoryl lipid A (MPLA). clinicaltrials.gov.

\section{NCT01606241 \{unpublished data only\}}

Mayo Clinic. Cyclophosphamide and vaccine therapy in treating patients with stage II-III breast, ovarian, primary peritoneal, or fallopian tube cancer. clinicaltrials.gov.

NCT01616303 \{unpublished data only\}

Quest PharmaTech Inc. A controlled study of the effectiveness of oregovomab (antibody) plus chemotherapy in advanced ovarian cancer. clinicaltrials.gov.

NCT01621542 \{unpublished data only\}

Sunovion. Clinical study of WT2725 in patients with advanced solid malignancies. clinicaltrials.gov.

NCT01673217 \{unpublished data only\}

Roswell Park Cancer Institute. Decitabine, vaccine therapy, and pegylated liposomal doxorubicin hydrochloride in treating patients with recurrent ovarian epithelial cancer, fallopian tube cancer, or peritoneal cancer. clinicaltrials.gov.

NCT02111941 \{unpublished data only\}

Mayo Clinic. Vaccine therapy in treating patients with stage IIICIV ovarian epithelial, fallopian tube, or primary peritoneal cavity cancer following surgery and chemotherapy. clinicaltrials.gov. 
NCT02132988 \{unpublished data only\}

Mackay Memorial Hospital. Trial of active immunotherapy with Globo H-KLH (OPT-822/821) in women who have nonprogressive ovarian cancer. clinicaltrials.gov.

\section{NCT02146313 \{unpublished data only\}}

Genentech, Inc. A study evaluating the safety and pharmacokinetics of DMUC4064A in participants with platinumresistant ovarian cancer or unresectable pancreatic cancer. clinicaltrials.gov.

\section{NCT02166905 \{unpublished data only\}}

Roswell Park Cancer Institute. DEC-205/NY-ESO-1 fusion protein CDX-1401, Poly ICLC, and IDO1 inhibitor INCB024360 in treating patients with ovarian, fallopian tube, or primary peritoneal cancer in remission. clinicaltrials.gov.

\section{NCT02275039 \{unpublished data only\}}

City of Hope Medical Center. P53MVA vaccine and gemcitabine hydrochloride in treating patients with recurrent ovarian epithelial cancer. clinicaltrials.gov.

\section{NCT02387125 \{unpublished data only\}}

Immune Design. Phase 1b safety study of CMB305 in patients with locally advanced, relapsed, or metastatic cancer expressing NY-ESO-1. clinicaltrials.gov.

\section{NCT02498665 \{unpublished data only\}}

Boston Biomedical, Inc. A study of DSP-7888 dosing emulsion in adult patients with advanced malignancies. clinicaltrials.gov.

\section{NCT02575807 \{unpublished data only\}}

Aduro Biotech, Inc. Safety and efficacy of CRS-207 with Epacadostat in platinum resistant ovarian, fallopian or peritoneal cancer (SEASCAPE). clinicaltrials.gov.

\section{NCT02737787 \{unpublished data only\}}

Memorial Sloan Kettering Cancer Center. A study of WT1 vaccine and nivolumab for recurrent ovarian cancer. clinicaltrials.gov.

\section{NCT02764333 \{unpublished data only\}}

Memorial Sloan Kettering Cancer Center. TPIV200/huFR-1 (a multi-epitope anti-folate receptor vaccine) plus anti-PD-L1 MEDI4736 (Durvalumab) in patients with platinum resistant ovarian cancer. clinicaltrials.gov.

\section{NCT02785250 \{unpublished data only\}}

ImmunoVaccine Technologies, Inc. Study of DPX-Survivac vaccine therapy and Epacadostat in patients with recurrent ovarian cancer. clinicaltrials.gov.

\section{NCT02833506 \{unpublished data only\}}

Roswell Park Cancer Institute. Sirolimus and vaccine therapy in treating patients with stage II-IV ovarian, fallopian tube, or primary peritoneal cancer. clinicaltrials.gov.

\section{NCT02933073 \{unpublished data only\}}

UConn Health. Study of oncoimmunome for the treatment of stage III/IV ovarian carcinoma. clinicaltrials.gov.

\section{NCT02978222 \{unpublished data only\}}

Tapimmune Inc. Folate receptor alpha peptide vaccine with GMCSF versus GM-CSF alone in patients with platinum sensitive ovarian cancer. Clinicaltrials.gov.

\section{NCT03029403 \{unpublished data only\}}

University Health Network, Toronto. Phase 2 study of Pembrolizumab, DPX-Survivac vaccine and Cyclophosphamide in advanced ovarian, primary peritoneal or fallopian tube cancer. clinicaltrials.gov.

\section{NCT03029611 \{unpublished data only\}}

University of Washington. IGFBP-2 vaccine and combination chemotherapy in treating patients with stage III-IV ovarian, fallopian tube, or primary peritoneal cancer undergoing surgery. clinicaltrials.gov.

\section{NCT03113487 \{unpublished data only\}}

City of Hope Medical Center. P53MVA and Pembrolizumab in treating patients with recurrent ovarian, primary peritoneal, or fallopian tube cancer. clinicaltrials.gov.

NCT03127098 \{unpublished data only\} NantCell, Inc. QUILT-3.040: ETBX-011 (Ad5 [E1-, E2b-]-CEA(6D)) vaccine in combination with ALT-803 (super-agonist IL-15) in subjects having CEA-expressing cancer. clinicaltrials.gov.

NCT03197584 \{unpublished data only\}

NantKwest, Inc. QUILT-3.051: NANT ovarian cancer vaccine: combination immunotherapy in subjects with epithelial ovarian cancer who have progressed on or after standard-of-care (SOC) therapy. clinicaltrials.gov.

\section{NCT03206047 \{unpublished data only\}}

National Cancer Institute ( $\mathrm{NCl}$ ). Atezolizumab, Guadecitabine, and CDX-1401 vaccine in treating patients with recurrent ovarian, fallopian tube, or primary peritoneal cancer. clinicaltrials.gov.

\section{NCT03300843 \{unpublished data only\}}

National Cancer Institute $(\mathrm{NCl})$. Ability of a dendritic cell vaccine to immunize melanoma or epithelial cancer patients against defined mutated neoantigens expressed by the autologous cancer. clinicaltrials.gov.

\section{Additional references}

\section{Agarwal 2006}

Agarwal R, Linch M, Kaye SB. Novel therapeutic agents in ovarian cancer. European Journal of Surgical Oncology 2006;32(8):875-86

\section{Antonia 2006}

Antonia SJ, Mirza N, Fricke I, Chiappori A, Thompson P, Williams $\mathrm{N}$, et al. Combination of $\mathrm{p} 53$ cancer vaccine with chemotherapy in patients with extensive stage small cell lung cancer. Clinical Cancer Research 2006;12(3):878-87.

\section{Brighton Collaboration 2009}

Brighton Collaboration. www.brightoncollaboration.org. 


\section{Britten 2008}

Britten CM, Gouttefangeas C, Welters MJ, Pawelec G, Koch S, Ottensmeier $\mathrm{C}$, et al. The CIMT-monitoring panel: a two-step approach to harmonize the enumeration of antigen-specific CD8+ T lymphocytes by structural and functional assays. Cancer Immunology, Immunotherapy 2008;57(3):289-302.

\section{CTCAE 2009}

Common Terminology Criteria for Adverse Events v4.03. National Institutes of Health, US Department of Health and Human Services, 2009, publication \# 09-7473.

\section{Deeks 2003}

Deeks JJ, Dinnes J, D'Amico R, Sowden AJ, Sakarovitch C, Song F, et al. International Stroke Trial Collaborative Group, European Carotid Surgery Trial Collaborative Group. Evaluating non-randomised intervention studies. Health Technology Assessment 2003;7(27):1-173.

\section{Dong 2006}

Dong HP, Elstrand MB, Holth A, Silins I, Berner A, Trope CG, et al. NK- and B-cell infiltration correlates with worse outcome in metastatic ovarian carcinoma. American Journal of Clinical Pathology 2006;125(3):451-8.

\section{Drerup 2015}

Drerup JM, Liu Y, Padron AS, Murthy K, Hurez V, Zhang B, Curiel TJ. Immunotherapy for ovarian cancer. Current Treatment Options in Oncology 2015;16(1):317.

\section{Garnett 2008}

Garnett CT, Schlom J, Hodge JW. Combination of docetaxel and recombinant vaccine enhances $\mathrm{T}$-cell responses and antitumor activity: effects of docetaxel on immune enhancement. Clinical Cancer Research 2008;14(11):3536-44.

\section{Gooden 2011}

Gooden MJM, de Bock GH, Leffers N, Daemen T, Nijman HW. The prognostic influence of tumour-infiltrating lymphocytes in cancer: a systematic review with meta-analysis. British Journal of Cancer 2011;105:93-103.

\section{Guyatt 2008}

Guyatt GH, Oxman AD, Kunz R, Vist GE, Falck-Ytter Y, Schünemann HJ, GRADE Working Group. Rating quality of evidence and strength of recommendations: what is "quality of evidence" and why is it important to clinicians?. BMJ 2008;336(7651):995-8

\section{Hardwick 2016}

Hardwick N, Frankel PH, Cristea M. New approaches for immune directed treatment for ovarian cancer. Current Treatment Options in Oncology 2016;17(3):14.

\section{Higgins 2011}

Higgins JPT, Green S (editors). Cochrane Handbook for Systematic Reviews of Interventions Version 5.1.0 (updated March 2011). The Cochrane Collaboration, 2011. Available from www.cochrane-handbook.org.

\section{Laheru 2008}

Laheru D, Lutz E, Burke J, Biedrzycki B, Solt S, Onners B. Allogeneic granulocyte macrophage colony-stimulating factorsecreting tumor immunotherapy alone or in sequence with cyclophosphamide for metastatic pancreatic cancer: a pilot study of safety, feasibility, and immune activation. Clinical Cancer Research 2008;14(5):1455-63.

\section{Leffers 2009}

Leffers N, Daemen CAHH, van der Zee AGJ, Nijman HW. Multimodality treatment warranted for ovarian cancer: immunotherapy, a prerequisite to improve prognosis for this vicious disease. Immunotherapy 2009;1(2):163-5.

\section{Odunsi 2017}

Odunsi K. Immunotherapy in ovarian cancer. Annals of Oncology 2017;28(8):viii1-viii .

\section{Prat 2015}

Prat J. FIGO's staging classification for cancer of the ovary, fallopian tube, and peritoneum: abridged republication. Journal of Gynecologic Oncology 2015;26(2):87-9. [DOI: 10.3802/ jgo.2015.26.2.87]

\section{Raspollini 2005}

Raspollini MR, Castiglione F, Rossi Degl'innocenti D, Amunni G, Villanucci A, Garbini F, et al. Tumour-infiltrating gamma/delta T-lymphocytes are correlated with a brief disease-free interval in advanced ovarian serous carcinoma. Annals of Oncology 2005;16(4):590-6.

\section{Rustin 2004}

Rustin GJ, Quinn M, Thigpen T, du Bois A, Pujade-Lauraine E, Jakobsen A, et al. Re: new guidelines to evaluate the response to treatment in solid tumors (ovarian cancer). Journal of the National Cancer Institute 2004;96(6):487-8.

\section{Sato 2005}

Sato E, Olson SH, Ahn J, Bundy B, Nishikawa H, Qian F, et al. Intraepithelial CD8+ tumor-infiltrating lymphocytes and a high $\mathrm{CD} 8+$ /regulatory $T$ cell ratio are associated with favourable prognosis in ovarian cancer. Proceedings of the National Academy of Sciences of the United States of America 2005;102(51):18538-43.

\section{Therasse 2000}

Therasse P, Arbuck SG, Eisenhauer EA, Wanders J, Kaplan RS, Rubinstein $\mathrm{L}$, et al. New guidelines to evaluate the response to treatment in solid tumors. European Organization for Research and Treatment of Cancer, National Cancer Institute of the United States, National Cancer Institute of Canada. Journal of the National Cancer Institute 2000;92(3):205-16.

\section{Thigpen 2000}

Thigpen JT. Chemotherapy for advanced ovarian cancer: overview of randomized trials. Seminars in Oncology 2000;27(3 Suppl 7):11-6. 


\section{Torre 2012}

Torre LA, Bray F, Siegel RL, Ferlay J, Lortet-Tieulent J, Jemal A. Global cancer statistics, 2012. A Cancer Journal for Clinicians 2015;65(2):87-108.

\section{Trotti 2003}

Trotti A, Colevas A, Setser V, Rusch D, Jaques V, Budach C, et al. CTCAE v3.0: development of a comprehensive grading system for the adverse effects of cancer treatment. Seminars in Radiation Oncology 2003;13(3):176-81A.

\section{WHO 1979}

World Health Organization. Handbook for Reporting Results of Cancer Treatment. Geneva: World Health Organization, 1979.

\section{Zhang 2003}

Zhang L, Conejo-Garcia JR, Katsaros D, Gimotty PA,

Massobrio M, Regnani G, et al. Intratumoral T cells, recurrence,

\section{CHARACTERISTICS OFSTUDIES}

Characteristics of included studies [ordered by study ID]

Antonilli 2016

\begin{tabular}{ll}
\hline Methods & Uncontrolled phase I/II \\
\hline Participants & $\begin{array}{l}\text { 14 high-risk, disease-free ovarian cancer }(n=7) \text { or breast carcinoma participants }+3 \text { recurrent OC pa- } \\
\text { tients vaccinated for compassionate use }\end{array}$ \\
\hline Interventions & Triple peptide (MUC1, ErbB2, and CEA) with Montanide vaccine \\
\hline Outcomes & Safety \\
& Immune response \\
& Clinical response \\
\hline
\end{tabular}

Notes

\section{Risk of bias}

\begin{tabular}{lll}
\hline Bias & Authors' judgement & Support for judgement \\
\hline $\begin{array}{l}\text { Random sequence genera- } \\
\text { tion (selection bias) }\end{array}$ & High risk & Uncontrolled trial \\
\hline $\begin{array}{l}\text { Allocation concealment } \\
\text { (selection bias) }\end{array}$ & High risk & Uncontrolled trial \\
\hline $\begin{array}{l}\text { Blinding of participants } \\
\begin{array}{l}\text { and personnel (perfor- } \\
\text { mance bias) } \\
\text { All outcomes }\end{array}\end{array}$ & Unclear risk & Not explicitly stipulated \\
\hline
\end{tabular}

Blinding of outcome as-

Unclear risk Not explicitly stipulated and survival in epithelial ovarian cancer. New England Journal of Medicine 2003;348(3):203-13.

\section{References to other published versions of this review Leffers 2010 \\ Leffers N, Daemen T, Helfrich W, Boezen HM, Cohlen BJ, Melief K, et al. Antigen-specific active immunotherapy for ovarian cancer. Cochrane Database of Systematic Reviews 2010, Issue 1. [DOI: 10.1002/14651858.CD007287.pub2]}

\section{Leffers 2014}

Leffers N, Daemen T, Helfrich W, Boezen HM, Cohlen BJ, Melief CJM, et al. Antigen-specific active immunotherapy for ovarian cancer. Cochrane Database of Systematic Reviews 2014, Issue 9. [DOI: 10.1002/14651858.CD007287.pub3]

* Indicates the major publication for the study sessment (detection bias)

All outcomes 
Antonilli 2016 (Continued)

Incomplete outcome data Low risk All participants included in analysis
(attrition bias)

All outcomes

\begin{tabular}{lll}
\hline $\begin{array}{l}\text { Selective reporting (re- } \\
\text { porting bias) }\end{array}$ & Unclear risk & Study protocol not publicly available \\
\hline Other bias & Unclear risk & Information insufficient to permit judgement of 'low risk' or 'high risk' \\
\hline
\end{tabular}

Baumann 2011

\begin{tabular}{ll}
\hline Methods & Randomised controlled phase II trial \\
\hline Participants & 45 ovarian cancer patients with evidence of disease after first- or second-line chemotherapy \\
\hline Interventions & $\begin{array}{l}\text { Intraperitoneal trifunctional bispecific antibody (catumaxomab - EpCAM): low dose (10-10-10-10 } \mu \mathrm{g}) \text { vs } \\
\text { high dose (10-20-50-100 } \mu \mathrm{g})\end{array}$ \\
\hline Outcomes & Tumour responses \\
& Survival (progression-free survival/overall survival) \\
& Immune responses: humoral (HAMA) \\
& Adverse events
\end{tabular}

Notes

\section{Risk of bias}

\begin{tabular}{lll}
\hline Bias & Authors' judgement & Support for judgement \\
\hline $\begin{array}{l}\text { Random sequence genera- } \\
\text { tion (selection bias) }\end{array}$ & Low risk & Computer-generated randomisation list \\
\hline $\begin{array}{l}\text { Allocation concealment } \\
\text { (selection bias) }\end{array}$ & Unclear risk & Not explicitly stipulated \\
\hline $\begin{array}{l}\text { Blinding of participants } \\
\text { and personnel (perfor- } \\
\text { mance bias) }\end{array}$ & High risk & Open-label study \\
$\begin{array}{l}\text { All outcomes } \\
\text { Blinding of outcome as- } \\
\text { sessment (detection bias) } \\
\text { All outcomes }\end{array}$ & Unclear risk & Data insufficient to permit judgement \\
\hline $\begin{array}{l}\text { Incomplete outcome data } \\
\text { (attrition bias) } \\
\text { All outcomes }\end{array}$ & Low risk & \\
\hline
\end{tabular}

Selective reporting (re- $\quad$ Unclear risk $\quad$ Study protocol not publicly available
porting bias)

\begin{tabular}{ll}
\hline Other bias $\quad$ Low risk $\quad$ No other sources of bias detected \\
\hline
\end{tabular}


Berek 2001

\begin{tabular}{ll}
\hline Methods & Randomised placebo-controlled trial \\
\hline Participants & 252 stage III/IV ovarian cancer patients after successful primary surgery and chemotherapy \\
\hline Interventions & Intravenous monoclonal antibody (oregovomab - CA-125) vs placebo \\
\hline Outcomes & Survival (time to relapse) \\
& Immune responses: humoral (Ab2, HAMA) \\
\hline
\end{tabular}

Notes

\section{Risk of bias}

\begin{tabular}{|c|c|c|}
\hline Bias & Authors' judgement & Support for judgement \\
\hline $\begin{array}{l}\text { Random sequence genera- } \\
\text { tion (selection bias) }\end{array}$ & Unclear risk & $\begin{array}{l}\text { Information about the sequence generation process insufficient to permit } \\
\text { judgement of 'low risk' or 'high risk'; only abstract available }\end{array}$ \\
\hline $\begin{array}{l}\text { Allocation concealment } \\
\text { (selection bias) }\end{array}$ & Unclear risk & $\begin{array}{l}\text { Information insufficient to permit judgement of 'low risk' or 'high risk'; only } \\
\text { abstract available }\end{array}$ \\
\hline $\begin{array}{l}\text { Blinding of participants } \\
\text { and personnel (perfor- } \\
\text { mance bias) } \\
\text { All outcomes }\end{array}$ & Low risk & Double-blinded study \\
\hline $\begin{array}{l}\text { Blinding of outcome as- } \\
\text { sessment (detection bias) } \\
\text { All outcomes }\end{array}$ & Low risk & Double-blinded study \\
\hline $\begin{array}{l}\text { Incomplete outcome data } \\
\text { (attrition bias) } \\
\text { All outcomes }\end{array}$ & Unclear risk & $\begin{array}{l}\text { Information insufficient to permit judgement of 'low risk' or 'high risk'; only } \\
\text { abstract available }\end{array}$ \\
\hline $\begin{array}{l}\text { Selective reporting (re- } \\
\text { porting bias) }\end{array}$ & Unclear risk & $\begin{array}{l}\text { Information insufficient to permit judgement of 'low risk' or 'high risk'; only } \\
\text { abstract available }\end{array}$ \\
\hline Other bias & High risk & Publication bias possible \\
\hline
\end{tabular}

\section{Berek 2004}

\begin{tabular}{ll}
\hline Methods & Randomised placebo-controlled phase II trial \\
\hline Participants & 145 stage III/IV ovarian cancer patients with complete clinical response to primary therapy \\
\hline Interventions & Intravenous monoclonal antibody (oregovomab) vs placebo \\
\hline Outcomes & Survival (time to relapse/overall survival) \\
Immune responses: humoral (Ab2, HAMA) \\
Adverse events
\end{tabular}


Berek 2004 (Continued)

Notes

\section{Risk of bias}

\begin{tabular}{|c|c|c|}
\hline Bias & Authors' judgement & Support for judgement \\
\hline $\begin{array}{l}\text { Random sequence genera- } \\
\text { tion (selection bias) }\end{array}$ & Unclear risk & $\begin{array}{l}\text { Information about the sequence generation process insufficient to permit } \\
\text { judgement of 'low risk' or 'high risk' }\end{array}$ \\
\hline $\begin{array}{l}\text { Allocation concealment } \\
\text { (selection bias) }\end{array}$ & Unclear risk & Information insufficient to permit judgement of 'low risk' or 'high risk' \\
\hline $\begin{array}{l}\text { Blinding of participants } \\
\text { and personnel (perfor- } \\
\text { mance bias) } \\
\text { All outcomes }\end{array}$ & Unclear risk & Information insufficient to permit judgement of 'low risk' or 'high risk' \\
\hline $\begin{array}{l}\text { Blinding of outcome as- } \\
\text { sessment (detection bias) } \\
\text { All outcomes }\end{array}$ & Unclear risk & Information insufficient to permit judgement of 'low risk' or 'high risk' \\
\hline $\begin{array}{l}\text { Incomplete outcome data } \\
\text { (attrition bias) } \\
\text { All outcomes }\end{array}$ & Low risk & $\begin{array}{l}\text { Missing outcome data balanced in numbers across intervention groups, with } \\
\text { similar reasons for missing data across groups }\end{array}$ \\
\hline $\begin{array}{l}\text { Selective reporting (re- } \\
\text { porting bias) }\end{array}$ & Unclear risk & Information insufficient to permit judgement of 'low risk' or 'high risk' \\
\hline Other bias & Low risk & No other sources of bias detected \\
\hline
\end{tabular}

Berek 2009

\begin{tabular}{ll}
\hline Methods & Randomised placebo-controlled phase III trial \\
\hline Participants & 371 stage III/IV ovarian cancer patients with complete clinical response to primary therapy \\
\hline Interventions & Intravenous monoclonal antibody (oregovomab) vs placebo \\
\hline Outcomes & Survival (time to relapse) \\
Immune responses \\
Adverse events
\end{tabular}

Notes

\section{Risk of bias}

\begin{tabular}{lll}
\hline Bias & Authors' judgement & Support for judgement \\
\hline $\begin{array}{l}\text { Random sequence genera- } \\
\text { tion (selection bias) }\end{array}$ & Low risk & Centralised randomisation procedure \\
\hline $\begin{array}{l}\text { Allocation concealment } \\
\text { (selection bias) }\end{array}$ & Low risk & Centralised randomisation procedure \\
\hline
\end{tabular}




\section{Berek 2009 (Continued)}

Blinding of participants Low risk Blinded to treatment assignment, post-randomisation immune responses, and and personnel (perforCA-125 measurements mance bias)

All outcomes

\section{Blinding of outcome as- Low risk} sessment (detection bias)

All outcomes
Blinded to treatment assignment, post-randomisation immune responses, and CA-125 measurements
Incomplete outcome data Low risk (attrition bias)

All outcomes

All outcomes

Selective reporting (re- Unclear risk Information insufficient to permit judgement of 'low risk' or 'high risk'
porting bias)

\begin{tabular}{ll}
\hline Other bias $\quad$ Low risk $\quad$ No other sources of bias detected \\
\hline
\end{tabular}

Berinstein 2012

\begin{tabular}{ll}
\hline Methods & Uncontrolled phase I study \\
\hline Participants & $\begin{array}{l}\text { 23 late-stage cancer HLA-A2+ participants with complete or partial response to primary therapy (ovari- } \\
\text { an cancer } \mathrm{n}=6 \text { ) }\end{array}$ \\
\hline Interventions & $\begin{array}{l}\text { Subcutaneous 7 short peptides (topoisomerase Ila, integrin } \beta 8 \text { subunit precursor, ABI-binding protein } \\
\text { C3, TACE/ADAM17, junction plakglobin, EDDR1, BAP31) } \\
\text { Adjuvant: DepoVax }\end{array}$ \\
\hline Outcomes & Survival (time to progression) \\
& Tumour response \\
& Adverse events
\end{tabular}

Notes

\section{Risk of bias}

\begin{tabular}{lll}
\hline Bias & Authors' judgement & Support for judgement \\
\hline $\begin{array}{l}\text { Random sequence genera- } \\
\text { tion (selection bias) }\end{array}$ & High risk & Uncontrolled trial \\
\hline $\begin{array}{l}\text { Allocation concealment } \\
\text { (selection bias) }\end{array}$ & High risk & Uncontrolled trial \\
\hline
\end{tabular}

Blinding of participants Unclear risk Information insufficient to permit judgement of 'low risk' or 'high risk'
and personnel (perfor-
mance bias)
All outcomes

\begin{tabular}{|c|c|c|}
\hline $\begin{array}{l}\text { Blinding of outcome as- } \\
\text { sessment (detection bias) } \\
\text { All outcomes }\end{array}$ & Unclear risk & Information insufficient to permit judgement of 'low risk' or 'high risk' \\
\hline
\end{tabular}


Berinstein 2012 (Continued)
Incomplete outcome data
(attrition bias)
Low risk All participants with OC included in analysis

All outcomes

\begin{tabular}{lll}
\hline $\begin{array}{l}\text { Selective reporting (re- } \\
\text { porting bias) }\end{array}$ & Unclear risk & Information insufficient to permit judgement of 'low risk' or 'high risk' \\
\hline Other bias & Low risk & No other sources of bias detected \\
\hline
\end{tabular}

\section{Berinstein 2013}

\begin{tabular}{ll}
\hline Methods & Uncontrolled phase I study \\
\hline Participants & 19 women with ovarian cancer with unknown disease status \\
\hline Interventions & Subcutaneous peptides (survivin) \\
& Adjuvant: DepoVax \\
\hline Outcomes & Immune responses (cellular) \\
& Adverse events \\
\hline Notes & \\
\hline
\end{tabular}

\section{Risk of bias}

\begin{tabular}{|c|c|c|}
\hline Bias & Authors' judgement & Support for judgement \\
\hline $\begin{array}{l}\text { Random sequence genera- } \\
\text { tion (selection bias) }\end{array}$ & High risk & Uncontrolled trial \\
\hline $\begin{array}{l}\text { Allocation concealment } \\
\text { (selection bias) }\end{array}$ & High risk & Uncontrolled trial \\
\hline $\begin{array}{l}\text { Blinding of participants } \\
\text { and personnel (perfor- } \\
\text { mance bias) } \\
\text { All outcomes }\end{array}$ & Unclear risk & Information insufficient to permit judgement of 'low risk' or 'high risk' \\
\hline $\begin{array}{l}\text { Blinding of outcome as- } \\
\text { sessment (detection bias) } \\
\text { All outcomes }\end{array}$ & Unclear risk & Information insufficient to permit judgement of 'low risk' or 'high risk' \\
\hline $\begin{array}{l}\text { Incomplete outcome data } \\
\text { (attrition bias) } \\
\text { All outcomes }\end{array}$ & Unclear risk & Information insufficient to permit judgement of 'low risk' or 'high risk' \\
\hline $\begin{array}{l}\text { Selective reporting (re- } \\
\text { porting bias) }\end{array}$ & Unclear risk & Information insufficient to permit judgement of 'low risk' or 'high risk' \\
\hline Other bias & Unclear risk & Information insufficient to permit judgement of 'low risk' or 'high risk' \\
\hline
\end{tabular}


Braly 2009

\begin{tabular}{ll}
\hline Methods & Randomised controlled phase II trial \\
\hline Participants & 40 stage III/IV ovarian cancer patients after primary debulking surgery with or without residual disease \\
\hline Interventions & $\begin{array}{l}\text { Intravenous monoclonal antibody (oregovomab - CA-125): concurrent (SIM) or delayed (OWD) with } \\
\text { standard carboplatin/paclitaxel primary chemotherapy }\end{array}$ \\
\hline Outcomes & Survival (progression-free survival) \\
& Clinical responses \\
& Immune responses \\
Adverse events
\end{tabular}

\section{Notes}

\section{Risk of bias}

\begin{tabular}{|c|c|c|}
\hline Bias & Authors' judgement & Support for judgement \\
\hline $\begin{array}{l}\text { Random sequence genera- } \\
\text { tion (selection bias) }\end{array}$ & Low risk & Block randomisation \\
\hline $\begin{array}{l}\text { Allocation concealment } \\
\text { (selection bias) }\end{array}$ & Unclear risk & Not described \\
\hline $\begin{array}{l}\text { Blinding of participants } \\
\text { and personnel (perfor- } \\
\text { mance bias) } \\
\text { All outcomes }\end{array}$ & Low risk & $\begin{array}{l}\text { No blinding or incomplete blinding, but the review authors judge that the out- } \\
\text { come is not likely to be influenced by lack of blinding }\end{array}$ \\
\hline $\begin{array}{l}\text { Blinding of outcome as- } \\
\text { sessment (detection bias) } \\
\text { All outcomes }\end{array}$ & Unclear risk & Information insufficient to permit judgement of 'low risk' or 'high risk' \\
\hline $\begin{array}{l}\text { Incomplete outcome data } \\
\text { (attrition bias) } \\
\text { All outcomes }\end{array}$ & Low risk & $\begin{array}{l}\text { Missing outcome data balanced in numbers across intervention groups, with } \\
\text { similar reasons for missing data across groups }\end{array}$ \\
\hline $\begin{array}{l}\text { Selective reporting (re- } \\
\text { porting bias) }\end{array}$ & Unclear risk & Information insufficient to permit judgement of 'low risk' or 'high risk' \\
\hline Other bias & Low risk & No other sources of bias detected \\
\hline
\end{tabular}

\section{Brossart 2000}

\begin{tabular}{ll}
\hline Methods & Uncontrolled phase $\mathrm{I} / \mathrm{Il}$ study \\
\hline Participants & $\begin{array}{l}10 \text { participants with measurable residual or recurrent breast or ovarian cancer (3 women with ovarian } \\
\text { cancer) }\end{array}$ \\
\hline Interventions & Subcutaneous peptide pulsed dendritic cells $(\mathrm{n}=1$ Her-2/Neu; $\mathrm{n}=2$ MUC 1$)$ \\
\hline Outcomes & Tumour responses
\end{tabular}


Brossart 2000 (Continued)

Immune response

Adverse events

\section{Notes}

Risk of bias

\begin{tabular}{|c|c|c|}
\hline Bias & Authors' judgement & Support for judgement \\
\hline $\begin{array}{l}\text { Random sequence genera- } \\
\text { tion (selection bias) }\end{array}$ & High risk & Uncontrolled trial \\
\hline $\begin{array}{l}\text { Allocation concealment } \\
\text { (selection bias) }\end{array}$ & High risk & Uncontrolled trial \\
\hline $\begin{array}{l}\text { Blinding of participants } \\
\text { and personnel (perfor- } \\
\text { mance bias) } \\
\text { All outcomes }\end{array}$ & Unclear risk & Information insufficient to permit judgement of 'low risk' or 'high risk' \\
\hline $\begin{array}{l}\text { Blinding of outcome as- } \\
\text { sessment (detection bias) } \\
\text { All outcomes }\end{array}$ & Unclear risk & Information insufficient to permit judgement of 'low risk' or 'high risk' \\
\hline $\begin{array}{l}\text { Incomplete outcome data } \\
\text { (attrition bias) } \\
\text { All outcomes }\end{array}$ & Unclear risk & Information insufficient to permit judgement of 'low risk' or 'high risk' \\
\hline $\begin{array}{l}\text { Selective reporting (re- } \\
\text { porting bias) }\end{array}$ & Unclear risk & Information insufficient to permit judgement of 'low risk' or 'high risk' \\
\hline Other bias & Unclear risk & Information insufficient to permit judgement of 'low risk' or 'high risk' \\
\hline
\end{tabular}

Buzzonetti 2014

\begin{tabular}{ll}
\hline Methods & Randomised double-blind placebo-controlled trial \\
\hline Participants & $\begin{array}{l}129 \text { participants }(\mathrm{n}=91 \text { treatment arm; } \mathrm{n}=38 \text { placebo arm) with ovarian cancer in complete clinical re- } \\
\text { mission after primary treatment }\end{array}$ \\
\hline Interventions & Subcutaneous monoclonal antibody (abagovomab-CA-125) \\
\hline Outcomes & Survival \\
\hline Notes & Substudy of MIMOSA trial (NCT00418574)
\end{tabular}

\section{Risk of bias}

\begin{tabular}{lll}
\hline Bias & Authors' judgement & Support for judgement \\
\hline $\begin{array}{l}\text { Random sequence genera- } \\
\text { tion (selection bias) }\end{array}$ & Low risk & Centralised randomisation \\
\hline
\end{tabular}


Buzzonetti 2014 (Continued)

\begin{tabular}{lll}
$\begin{array}{l}\text { Allocation concealment } \\
\text { (selection bias) }\end{array}$ & Low risk & Centralised randomisation \\
\hline $\begin{array}{l}\text { Blinding of participants } \\
\text { and personnel (perfor- }\end{array}$ & Unclear risk & Unclear whether samples used were coded for key study personnel \\
mance bias) & & \\
All outcomes &
\end{tabular}

Blinding of outcome as- Unclear risk No information on blinding of outcome assessors

sessment (detection bias)

All outcomes

Incomplete outcome data High risk Unknown why and which samples are missing
(attrition bias)

All outcomes

\begin{tabular}{lll}
\hline $\begin{array}{l}\text { Selective reporting (re- } \\
\text { porting bias) }\end{array}$ & Unclear risk & Information insufficient to permit judgement of 'low risk' or 'high risk' \\
\hline Other bias & Low risk & No other sources of bias detected \\
\hline
\end{tabular}

\section{Chianese-Bullock 2008}

\begin{tabular}{ll}
\hline Methods & Uncontrolled phase I study \\
\hline Participants & 9 women with ovarian cancer with or without residual or recurrent disease after primary therapy \\
\hline Interventions & Subcutaneous and intradermal multi-peptide vaccine (FBP, Her-2/Neu, MAGE-A1) \\
& Adjuvant: Montanide ISA-51, GM-CSF \\
\hline Outcomes & Tumour responses \\
& Immune response \\
& Adverse events
\end{tabular}

\section{Notes}

\section{Risk of bias}

\begin{tabular}{|c|c|c|}
\hline Bias & Authors' judgement & Support for judgement \\
\hline $\begin{array}{l}\text { Random sequence genera- } \\
\text { tion (selection bias) }\end{array}$ & High risk & Uncontrolled trial \\
\hline $\begin{array}{l}\text { Allocation concealment } \\
\text { (selection bias) }\end{array}$ & High risk & Uncontrolled trial \\
\hline $\begin{array}{l}\text { Blinding of participants } \\
\text { and personnel (perfor- } \\
\text { mance bias) } \\
\text { All outcomes }\end{array}$ & Unclear risk & Information insufficient to permit judgement of 'low risk' or 'high risk' \\
\hline $\begin{array}{l}\text { Blinding of outcome as- } \\
\text { sessment (detection bias) }\end{array}$ & Unclear risk & Information insufficient to permit judgement of 'low risk' or 'high risk' \\
\hline
\end{tabular}


Chianese-Bullock 2008 (Continued)

All outcomes

Incomplete outcome data Unclear risk Information insufficient to permit judgement of 'low risk' or 'high risk'
(attrition bias)

(attrition bias)

All outcomes

Selective reporting (re- Unclear risk Information insufficient to permit judgement of 'low risk' or 'high risk'
porting bias)

\begin{tabular}{ll}
\hline Other bias $\quad$ Unclear risk $\quad$ Information insufficient to permit judgement of 'low risk' or 'high risk' \\
\hline
\end{tabular}

Chu 2012

\begin{tabular}{ll}
\hline Methods & Randomised controlled phase I/II study \\
\hline Participants & $\begin{array}{l}\text { 14 ovarian cancer patients with complete clinical response to primary therapy (10 received treatment } \\
\text { so far) }\end{array}$ \\
\hline Interventions & $\begin{array}{l}\text { Intradermal peptide pulsed dendritic cells (Her-2/Neu, hTERT, PADRE): vaccine alone vs single dose of } \\
\text { cyclophosphamide before first vaccination }\end{array}$ \\
\hline Outcomes & $\begin{array}{l}\text { Tumour responses } \\
\text { Immune response }\end{array}$ \\
& Adverse events \\
\hline
\end{tabular}

Notes

\section{Risk of bias}

\begin{tabular}{|c|c|c|}
\hline Bias & Authors' judgement & Support for judgement \\
\hline $\begin{array}{l}\text { Random sequence genera- } \\
\text { tion (selection bias) }\end{array}$ & Unclear risk & $\begin{array}{l}\text { Information about the sequence generation process insufficient to permit } \\
\text { judgement of 'low risk' or 'high risk' }\end{array}$ \\
\hline $\begin{array}{l}\text { Allocation concealment } \\
\text { (selection bias) }\end{array}$ & Unclear risk & Information insufficient to permit judgement of 'low risk' or 'high risk' \\
\hline $\begin{array}{l}\text { Blinding of participants } \\
\text { and personnel (perfor- } \\
\text { mance bias) } \\
\text { All outcomes }\end{array}$ & Low risk & $\begin{array}{l}\text { No blinding or incomplete blinding, but review authors judge that the out- } \\
\text { come is not likely to be influenced by lack of blinding }\end{array}$ \\
\hline $\begin{array}{l}\text { Blinding of outcome as- } \\
\text { sessment (detection bias) } \\
\text { All outcomes }\end{array}$ & Unclear risk & Information insufficient to permit judgement of 'low risk' or 'high risk' \\
\hline $\begin{array}{l}\text { Incomplete outcome data } \\
\text { (attrition bias) } \\
\text { All outcomes }\end{array}$ & Low risk & $\begin{array}{l}\text { Missing outcome data balanced in numbers across intervention groups, with } \\
\text { similar reasons for missing data across groups }\end{array}$ \\
\hline $\begin{array}{l}\text { Selective reporting (re- } \\
\text { porting bias) }\end{array}$ & Unclear risk & Information insufficient to permit judgement of 'low risk' or 'high risk' \\
\hline Other bias & High risk & Early termination due to financial limitations \\
\hline
\end{tabular}


Dhodapkar 2012

\begin{tabular}{|c|c|c|}
\hline Methods & \multicolumn{2}{|c|}{ Uncontrolled phase I study } \\
\hline Participants & \multicolumn{2}{|c|}{45 participants with advanced malignancies; exact disease status unknown (ovarian cancer $n=6$ ) } \\
\hline Interventions & \multirow{2}{*}{\multicolumn{2}{|c|}{$\begin{array}{l}\text { Fusion protein of full-length tumour antigen and human monoclonal an } \\
\text { Adjuvants: TLR agonist resiquimod and/or poly-ICLC }\end{array}$}} \\
\hline & & \\
\hline Outcomes & \multicolumn{2}{|c|}{ Immune responses (cellular and humoral) } \\
\hline & \multicolumn{2}{|l|}{ Adverse events } \\
\hline \multicolumn{3}{|l|}{ Notes } \\
\hline \multicolumn{3}{|l|}{ Risk of bias } \\
\hline Bias & Authors' judgement & Support for judgement \\
\hline $\begin{array}{l}\text { Random sequence genera- } \\
\text { tion (selection bias) }\end{array}$ & High risk & Uncontrolled trial \\
\hline $\begin{array}{l}\text { Allocation concealment } \\
\text { (selection bias) }\end{array}$ & High risk & Uncontrolled trial \\
\hline $\begin{array}{l}\text { Blinding of participants } \\
\text { and personnel (perfor- } \\
\text { mance bias) } \\
\text { All outcomes }\end{array}$ & Unclear risk & Information insufficient to permit judgement of 'low risk' or 'high risk' \\
\hline $\begin{array}{l}\text { Blinding of outcome as- } \\
\text { sessment (detection bias) } \\
\text { All outcomes }\end{array}$ & Unclear risk & Information insufficient to permit judgement of 'low risk' or 'high risk' \\
\hline $\begin{array}{l}\text { Incomplete outcome data } \\
\text { (attrition bias) } \\
\text { All outcomes }\end{array}$ & Unclear risk & Information insufficient to permit judgement of 'low risk' or 'high risk' \\
\hline $\begin{array}{l}\text { Selective reporting (re- } \\
\text { porting bias) }\end{array}$ & Unclear risk & Information insufficient to permit judgement of 'low risk' or 'high risk' \\
\hline Other bias & Unclear risk & Information insufficient to permit judgement of 'low risk' or 'high risk' \\
\hline
\end{tabular}

Diefenbach 2008

\begin{tabular}{ll}
\hline Methods & Uncontrolled phase I study \\
\hline Participants & 9 participants with ovarian cancer with complete clinical response to primary therapy \\
\hline Interventions & Subcutaneous short peptide (NY-ESO-1) \\
& Adjuvant: Montanide ISA-51 \\
\hline Outcomes & Survival (time to progression)
\end{tabular}


Diefenbach 2008 (Continued)

Tumour responses

Immune responses: cellular and humoral

Adverse events

\section{Notes}

\section{Risk of bias}

\begin{tabular}{|c|c|c|}
\hline Bias & Authors' judgement & Support for judgement \\
\hline $\begin{array}{l}\text { Random sequence genera- } \\
\text { tion (selection bias) }\end{array}$ & High risk & Uncontrolled trial \\
\hline $\begin{array}{l}\text { Allocation concealment } \\
\text { (selection bias) }\end{array}$ & High risk & Uncontrolled trial \\
\hline $\begin{array}{l}\text { Blinding of participants } \\
\text { and personnel (perfor- } \\
\text { mance bias) } \\
\text { All outcomes }\end{array}$ & Unclear risk & Information insufficient to permit judgement of 'low risk' or 'high risk' \\
\hline $\begin{array}{l}\text { Blinding of outcome as- } \\
\text { sessment (detection bias) } \\
\text { All outcomes }\end{array}$ & Unclear risk & Information insufficient to permit judgement of 'low risk' or 'high risk' \\
\hline $\begin{array}{l}\text { Incomplete outcome data } \\
\text { (attrition bias) } \\
\text { All outcomes }\end{array}$ & Unclear risk & Information insufficient to permit judgement of 'low risk' or 'high risk' \\
\hline $\begin{array}{l}\text { Selective reporting (re- } \\
\text { porting bias) }\end{array}$ & Unclear risk & Information insufficient to permit judgement of 'low risk' or 'high risk' \\
\hline Other bias & Unclear risk & Information insufficient to permit judgement of 'low risk' or 'high risk' \\
\hline
\end{tabular}

\section{Dijkgraaf 2015}

\begin{tabular}{ll}
\hline Methods & Controlled phase I/II trial \\
\hline Participants & 15 participants with platinum-resistant ovarian cancers expressing 'mutant' p53 \\
\hline Interventions & C1: 6 cycles of gemcitabine $(n=3)$ \\
& C2: 6 cycles of gemcitabine and interferon alpha-2b 7 days before and 22 days after first cycle of gemc- \\
itabine $(n=6)$ & \\
C3: 6 cycles of gemcitabine and interferon alpha-2b with p53 SLP vaccine 7 days before and 22 days af- \\
ter first cycle of gemcitabine $(n=6)$
\end{tabular}

\begin{tabular}{ll}
\hline Outcomes & Immune response \\
Safety \\
Clinical response
\end{tabular}

\section{Notes}


Dijkgraaf 2015 (Continued)

\section{Risk of bias}

\begin{tabular}{|c|c|c|}
\hline Bias & Authors' judgement & Support for judgement \\
\hline $\begin{array}{l}\text { Random sequence genera- } \\
\text { tion (selection bias) }\end{array}$ & High risk & Not randomised to treatment groups \\
\hline $\begin{array}{l}\text { Allocation concealment } \\
\text { (selection bias) }\end{array}$ & High risk & Sequencial allocation to treatment groups \\
\hline $\begin{array}{l}\text { Blinding of participants } \\
\text { and personnel (perfor- } \\
\text { mance bias) } \\
\text { All outcomes }\end{array}$ & Unclear risk & Information insufficient to permit judgement of 'low risk' or 'high risk' \\
\hline $\begin{array}{l}\text { Blinding of outcome as- } \\
\text { sessment (detection bias) } \\
\text { All outcomes }\end{array}$ & Unclear risk & Information insufficient to permit judgement of 'low risk' or 'high risk' \\
\hline $\begin{array}{l}\text { Incomplete outcome data } \\
\text { (attrition bias) } \\
\text { All outcomes }\end{array}$ & Unclear risk & Information insufficient to permit judgement of 'low risk' or 'high risk' \\
\hline $\begin{array}{l}\text { Selective reporting (re- } \\
\text { porting bias) }\end{array}$ & Unclear risk & Information insufficient to permit judgement of 'low risk' or 'high risk' \\
\hline Other bias & Low risk & No other sources of bias detected \\
\hline
\end{tabular}

Ehlen 2005

\begin{tabular}{ll}
\hline Methods & Uncontrolled phase Il study \\
\hline Participants & 13 women with ovarian cancer with measurable recurrent disease \\
\hline Interventions & Intravenous monoclonal antibody (oregovomab - CA-125) \\
\hline Outcomes & Survival (time to progression/survival) \\
& Tumour responses \\
& Immune responses: humoral (Ab2, Ab3, HAMA), cellular \\
\hline $\begin{array}{l}\text { Notes } \\
\text { Risk of bias }\end{array}$ & Adverse events \\
\hline Bias & Authors' judgement Support for judgement \\
\hline $\begin{array}{l}\text { Random sequence genera- } \\
\text { tion (selection bias) }\end{array}$ & High risk \\
\hline $\begin{array}{l}\text { Allocation concealment } \\
\text { selection bias) }\end{array}$ & High risk \\
\hline
\end{tabular}


Ehlen 2005 (Continued)

Blinding of participants Unclear risk Information insufficient to permit judgement of 'low risk' or 'high risk' and personnel (performance bias)

All outcomes

\begin{tabular}{l}
\hline Blinding of outcome as- $\quad$ Unclear risk Information insufficient to permit judgement of 'low risk' or 'high risk' \\
sessment (detection bias) \\
All outcomes
\end{tabular}

All outcomes

Incomplete outcome data Unclear risk Information insufficient to permit judgement of 'low risk' or 'high risk'
(attrition bias)

All outcom

\begin{tabular}{lll}
\hline $\begin{array}{l}\text { Selective reporting (re- } \\
\text { porting bias) }\end{array}$ & Unclear risk & Information insufficient to permit judgement of 'low risk' or 'high risk' \\
\hline Other bias & Unclear risk & Information insufficient to permit judgement of 'low risk' or 'high risk' \\
\hline
\end{tabular}

Freedman 1998

\begin{tabular}{ll}
\hline Methods & Randomised controlled phase II study \\
\hline Participants & $\begin{array}{l}\text { 30 ovarian cancer patients previously treated with platinum-based chemotherapy (disease status at } \\
\text { study entry not described) }\end{array}$ \\
\hline Interventions & Subcutaneous KLH conjugate (Sialyl-Tn) at 2 different dosages \\
& Adjuvant: Detox B \\
\hline Outcomes & Survival (progression-free interval/survival) \\
& Tumour responses \\
Adverse events
\end{tabular}

Notes

\section{Risk of bias}

\begin{tabular}{lll}
\hline Bias & Authors' judgement & Support for judgement \\
\hline $\begin{array}{l}\text { Random sequence genera- } \\
\text { tion (selection bias) }\end{array}$ & Unclear risk & $\begin{array}{l}\text { Information about the sequence generation process insufficient to permit } \\
\text { judgement of 'low risk' or 'high risk'; only abstract available }\end{array}$ \\
\hline $\begin{array}{l}\text { Allocation concealment } \\
\text { (selection bias) }\end{array}$ & Unclear risk & $\begin{array}{l}\text { Information insufficient to permit judgement of 'low risk' or 'high risk'; only } \\
\text { abstract available }\end{array}$ \\
\hline $\begin{array}{l}\text { Blinding of participants } \\
\text { and personnel (perfor- } \\
\text { mance bias) }\end{array}$ & Unclear risk & Information insufficient to permit judgement of 'low risk' or 'high risk' \\
$\begin{array}{l}\text { All outcomes } \\
\begin{array}{l}\text { Blinding of outcome as- } \\
\text { sessment (detection bias) } \\
\text { All outcomes }\end{array}\end{array}$ & Unclear risk & $\begin{array}{l}\text { Information insufficient to permit judgement of 'low risk' or 'high risk'; only } \\
\text { abstract available }\end{array}$ \\
\hline
\end{tabular}


Freedman 1998 (Continued)

Incomplete outcome data Unclear risk Reporting of attrition/exclusions insufficient to permit judgement of 'low risk' (attrition bias)

or 'high risk'; only abstract available

All outcomes

\begin{tabular}{|c|c|c|}
\hline $\begin{array}{l}\text { Selective reporting (re- } \\
\text { porting bias) }\end{array}$ & Unclear risk & $\begin{array}{l}\text { Information insufficient to permit judgement of 'low risk' or 'high risk'; only } \\
\text { abstract available }\end{array}$ \\
\hline
\end{tabular}

Other bias High risk Publication bias possible

\section{Galanis 2010}

\begin{tabular}{ll}
\hline Methods & Uncontrolled phase I study \\
\hline Participants & 21 ovarian cancer patients with persistent, recurrent, or progressive disease after primary therapy \\
\hline Interventions & Intraperitoneal recombinant measles virus (CEA) \\
\hline Outcomes & Tumour responses \\
& Immune responses (humoral) \\
& Adverse events \\
\hline
\end{tabular}

Notes

\section{Risk of bias}

\begin{tabular}{|c|c|c|}
\hline Bias & Authors' judgement & Support for judgement \\
\hline $\begin{array}{l}\text { Random sequence genera- } \\
\text { tion (selection bias) }\end{array}$ & High risk & Uncontrolled trial \\
\hline $\begin{array}{l}\text { Allocation concealment } \\
\text { (selection bias) }\end{array}$ & High risk & Uncontrolled trial and sequential allocation \\
\hline $\begin{array}{l}\text { Blinding of participants } \\
\text { and personnel (perfor- } \\
\text { mance bias) } \\
\text { All outcomes }\end{array}$ & Unclear risk & Information insufficient to permit judgement of 'low risk' or 'high risk' \\
\hline $\begin{array}{l}\text { Blinding of outcome as- } \\
\text { sessment (detection bias) } \\
\text { All outcomes }\end{array}$ & Unclear risk & Information insufficient to permit judgement of 'low risk' or 'high risk' \\
\hline $\begin{array}{l}\text { Incomplete outcome data } \\
\text { (attrition bias) } \\
\text { All outcomes }\end{array}$ & Unclear risk & Information insufficient to permit judgement of 'low risk' or 'high risk' \\
\hline $\begin{array}{l}\text { Selective reporting (re- } \\
\text { porting bias) }\end{array}$ & Unclear risk & Information insufficient to permit judgement of 'low risk' or 'high risk' \\
\hline Other bias & Unclear risk & Information insufficient to permit judgement of 'low risk' or 'high risk' \\
\hline
\end{tabular}


Goh 2013

\begin{tabular}{ll}
\hline Methods & Randomised controlled phase Ilb trial \\
\hline Participants & 63 patients in complete remission after primary therapy \\
\hline Interventions & Protein-pulsed dendritic cells (MUC1) vs standard of care \\
\hline Outcomes & Survival \\
Immune responses (cellular) \\
Adverse events
\end{tabular}

Notes

\section{Risk of bias}

\begin{tabular}{|c|c|c|}
\hline Bias & Authors' judgement & Support for judgement \\
\hline $\begin{array}{l}\text { Random sequence genera- } \\
\text { tion (selection bias) }\end{array}$ & Unclear risk & $\begin{array}{l}\text { Information about the sequence generation process insufficient to permit } \\
\text { judgement of 'low risk' or 'high risk'; only abstract available }\end{array}$ \\
\hline $\begin{array}{l}\text { Allocation concealment } \\
\text { (selection bias) }\end{array}$ & Unclear risk & $\begin{array}{l}\text { Information insufficient to permit judgement of 'low risk' or 'high risk'; only } \\
\text { abstract available }\end{array}$ \\
\hline $\begin{array}{l}\text { Blinding of participants } \\
\text { and personnel (perfor- } \\
\text { mance bias) } \\
\text { All outcomes }\end{array}$ & Unclear risk & $\begin{array}{l}\text { Information insufficient to permit judgement of 'low risk' or 'high risk'; only } \\
\text { abstract available }\end{array}$ \\
\hline $\begin{array}{l}\text { Blinding of outcome as- } \\
\text { sessment (detection bias) } \\
\text { All outcomes }\end{array}$ & Unclear risk & $\begin{array}{l}\text { Information insufficient to permit judgement of 'low risk' or 'high risk'; only } \\
\text { abstract available }\end{array}$ \\
\hline $\begin{array}{l}\text { Incomplete outcome data } \\
\text { (attrition bias) } \\
\text { All outcomes }\end{array}$ & Unclear risk & $\begin{array}{l}\text { Reporting of attrition/exclusions insufficient to permit judgement of 'low risk' } \\
\text { or 'high risk'; only abstract available }\end{array}$ \\
\hline $\begin{array}{l}\text { Selective reporting (re- } \\
\text { porting bias) }\end{array}$ & Unclear risk & $\begin{array}{l}\text { Information insufficient to permit judgement of 'low risk' or 'high risk'; only } \\
\text { abstract available }\end{array}$ \\
\hline Other bias & Unclear risk & $\begin{array}{l}\text { Information insufficient to permit judgement of 'low risk' or 'high risk'; only } \\
\text { abstract available; study recently completed }\end{array}$ \\
\hline
\end{tabular}

Gordon 2004

\begin{tabular}{ll}
\hline Methods & Uncontrolled phase Il study \\
\hline Participants & 20 ovarian cancer patients with recurrent disease \\
\hline Interventions & Intravenous monoclonal antibody (oregovomab - CA-125) \\
\hline Outcomes & Survival (time to progression/survival) \\
& Tumour responses \\
& Immune responses: humoral (Ab2, Ab3, HAMA), cellular
\end{tabular}


Gordon 2004 (Continued)

Adverse events

Notes

\section{Risk of bias}

\begin{tabular}{|c|c|c|}
\hline Bias & Authors' judgement & Support for judgement \\
\hline $\begin{array}{l}\text { Random sequence genera- } \\
\text { tion (selection bias) }\end{array}$ & High risk & Uncontrolled trial \\
\hline $\begin{array}{l}\text { Allocation concealment } \\
\text { (selection bias) }\end{array}$ & High risk & Uncontrolled trial \\
\hline $\begin{array}{l}\text { Blinding of participants } \\
\text { and personnel (perfor- } \\
\text { mance bias) } \\
\text { All outcomes }\end{array}$ & Unclear risk & Information insufficient to permit judgement of 'low risk' or 'high risk' \\
\hline $\begin{array}{l}\text { Blinding of outcome as- } \\
\text { sessment (detection bias) } \\
\text { All outcomes }\end{array}$ & Unclear risk & Information insufficient to permit judgement of 'low risk' or 'high risk' \\
\hline $\begin{array}{l}\text { Incomplete outcome data } \\
\text { (attrition bias) } \\
\text { All outcomes }\end{array}$ & Unclear risk & Information insufficient to permit judgement of 'low risk' or 'high risk' \\
\hline $\begin{array}{l}\text { Selective reporting (re- } \\
\text { porting bias) }\end{array}$ & Unclear risk & Information insufficient to permit judgement of 'low risk' or 'high risk' \\
\hline Other bias & Unclear risk & Information insufficient to permit judgement of 'low risk' or 'high risk' \\
\hline
\end{tabular}

Gray 2016

\begin{tabular}{ll}
\hline Methods & Randomized controlled phase II \\
\hline Participants & 56 participants with epithelial ovarian cancer \\
\hline Interventions & Mucin 1 targeted dendritic cell vs standard of care \\
\hline Outcomes & Progression-free survival \\
& Overall survival \\
& Immune response \\
\hline Notes & Authors' judgement Support for judgement \\
\hline Risk of bias & Low risk \\
\hline Bias & Randomised trial \\
\hline $\begin{array}{l}\text { Random sequence genera- } \\
\text { tion (selection bias) }\end{array}$
\end{tabular}


Gray 2016 (Continued)

\begin{tabular}{|c|c|c|}
\hline $\begin{array}{l}\text { Allocation concealment } \\
\text { (selection bias) }\end{array}$ & Low risk & Randomised trial \\
\hline $\begin{array}{l}\text { Blinding of participants } \\
\text { and personnel (perfor- } \\
\text { mance bias) } \\
\text { All outcomes }\end{array}$ & Unclear risk & Information insufficient to permit judgement of 'low risk' or 'high risk' \\
\hline $\begin{array}{l}\text { Blinding of outcome as- } \\
\text { sessment (detection bias) } \\
\text { All outcomes }\end{array}$ & Unclear risk & Information insufficient to permit judgement of 'low risk' or 'high risk' \\
\hline $\begin{array}{l}\text { Incomplete outcome data } \\
\text { (attrition bias) } \\
\text { All outcomes }\end{array}$ & Unclear risk & Information insufficient to permit judgement of 'low risk' or 'high risk' \\
\hline $\begin{array}{l}\text { Selective reporting (re- } \\
\text { porting bias) }\end{array}$ & Unclear risk & Information insufficient to permit judgement of 'low risk' or 'high risk' \\
\hline Other bias & Unclear risk & Information insufficient to permit judgement of 'low risk' or 'high risk' \\
\hline
\end{tabular}

\section{Gribben 2005}

\begin{tabular}{ll}
\hline Methods & Uncontrolled phase I study \\
\hline Participants & 17 participants with advanced cancer with progressive disease (ovarian cancer $\mathrm{n}=6)$ \\
\hline Interventions & Intramuscular plasmid DNA vaccine (CYP1B1) \\
\hline Outcomes & Tumour responses \\
& Immune responses (cellular) \\
& Adverse events \\
\hline
\end{tabular}

\section{Notes}

\section{Risk of bias}

\begin{tabular}{lll}
\hline Bias & Authors' judgement & Support for judgement \\
\hline $\begin{array}{l}\text { Random sequence genera- } \\
\text { tion (selection bias) }\end{array}$ & High risk & Uncontrolled trial \\
\hline $\begin{array}{l}\text { Allocation concealment } \\
\text { (selection bias) }\end{array}$ & High risk & Uncontrolled trial \\
\hline $\begin{array}{l}\text { Blinding of participants } \\
\begin{array}{l}\text { and personnel (perfor- } \\
\text { mance bias) }\end{array}\end{array}$ & Unclear risk & Information insufficient to permit judgement of 'low risk' or 'high risk' \\
$\begin{array}{l}\text { All outcomes } \\
\text { Blinding of outcome as- } \\
\text { sessment (detection bias) } \\
\begin{array}{l}\text { All outcomes } \\
\hline\end{array}\end{array}$ & Unclear risk & Information insufficient to permit judgement of 'low risk' or 'high risk' \\
\hline
\end{tabular}


Gribben 2005 (Continued)

Incomplete outcome data Unclear risk Information insufficient to permit judgement of 'low risk' or 'high risk'
(attrition bias)

All outcomes

\begin{tabular}{lll}
\hline $\begin{array}{l}\text { Selective reporting (re- } \\
\text { porting bias) }\end{array}$ & Unclear risk & Information insufficient to permit judgement of 'low risk' or 'high risk' \\
\hline Other bias & Unclear risk & Information insufficient to permit judgement of 'low risk' or 'high risk' \\
\hline
\end{tabular}

Gulley 2008

\begin{tabular}{ll}
\hline Methods & Uncontrolled phase I/II study \\
\hline Participants & $\begin{array}{l}25 \text { participants with CEA or MUC1 overexpressing metastatic cancer with progressive disease following } \\
\text { standard chemotherapy (ovarian cancer } n=3 \text { ) }\end{array}$ \\
\hline Interventions & Subcutaneous recombinant pox virus (CEA, MUC1): 1× vaccinia, $\geq 4$ fowlpox \\
& Adjuvant: local GM-CSF \\
\hline Outcomes & Survival (progression-free survival/overall survival) \\
& Immune responses: cellular, humoral \\
& Adverse events
\end{tabular}

Notes

\section{Risk of bias}

\begin{tabular}{|c|c|c|}
\hline Bias & Authors' judgement & Support for judgement \\
\hline $\begin{array}{l}\text { Random sequence genera- } \\
\text { tion (selection bias) }\end{array}$ & High risk & Uncontrolled trial \\
\hline $\begin{array}{l}\text { Allocation concealment } \\
\text { (selection bias) }\end{array}$ & High risk & Uncontrolled trial \\
\hline $\begin{array}{l}\text { Blinding of participants } \\
\text { and personnel (perfor- } \\
\text { mance bias) } \\
\text { All outcomes }\end{array}$ & Unclear risk & Information insufficient to permit judgement of 'low risk' or 'high risk' \\
\hline $\begin{array}{l}\text { Blinding of outcome as- } \\
\text { sessment (detection bias) } \\
\text { All outcomes }\end{array}$ & Unclear risk & Information insufficient to permit judgement of 'low risk' or 'high risk' \\
\hline $\begin{array}{l}\text { Incomplete outcome data } \\
\text { (attrition bias) } \\
\text { All outcomes }\end{array}$ & Unclear risk & Information insufficient to permit judgement of 'low risk' or 'high risk' \\
\hline $\begin{array}{l}\text { Selective reporting (re- } \\
\text { porting bias) }\end{array}$ & Unclear risk & Information insufficient to permit judgement of 'low risk' or 'high risk' \\
\hline Other bias & Unclear risk & Information insufficient to permit judgement of 'low risk' or 'high risk' \\
\hline
\end{tabular}


Heiss 2010

\begin{tabular}{ll}
\hline Methods & Randomised controlled open-label phase II/III trial \\
\hline Participants & 258 patients with malignant ascites due to epithelial cancer (ovarian cancer $\mathrm{n}=129)$ \\
\hline Interventions & Intraperitoneal trifunctional antibody (EpCAM) + paracentesis vs paracentesis \\
\hline Outcomes & Survival (puncture-free survival/overall survival) \\
& Immune responses (HAMA) \\
& Adverse events \\
\hline
\end{tabular}

Notes

\section{Risk of bias}

\begin{tabular}{|c|c|c|}
\hline Bias & Authors' judgement & Support for judgement \\
\hline $\begin{array}{l}\text { Random sequence genera- } \\
\text { tion (selection bias) }\end{array}$ & Unclear risk & $\begin{array}{l}\text { Information about the sequence generation process insufficient to permit } \\
\text { judgement of 'low risk' or 'high risk' }\end{array}$ \\
\hline $\begin{array}{l}\text { Allocation concealment } \\
\text { (selection bias) }\end{array}$ & Unclear risk & Information insufficient to permit judgement of 'low risk' or 'high risk' \\
\hline $\begin{array}{l}\text { Blinding of participants } \\
\text { and personnel (perfor- } \\
\text { mance bias) } \\
\text { All outcomes }\end{array}$ & Low risk & $\begin{array}{l}\text { No blinding or incomplete blinding, but the review authors judge that the out- } \\
\text { come is not likely to be influenced by lack of blinding }\end{array}$ \\
\hline $\begin{array}{l}\text { Blinding of outcome as- } \\
\text { sessment (detection bias) } \\
\text { All outcomes }\end{array}$ & Unclear risk & Information insufficient to permit judgement of 'low risk' or 'high risk' \\
\hline $\begin{array}{l}\text { Incomplete outcome data } \\
\text { (attrition bias) } \\
\text { All outcomes }\end{array}$ & High risk & $\begin{array}{l}\text { Reason for missing outcome data likely to be related to true outcome, with im- } \\
\text { balance in numbers or reasons for missing data across intervention groups }\end{array}$ \\
\hline $\begin{array}{l}\text { Selective reporting (re- } \\
\text { porting bias) }\end{array}$ & Unclear risk & Information insufficient to permit judgement of 'low risk' or 'high risk' \\
\hline Other bias & Low risk & No other sources of bias detected \\
\hline
\end{tabular}

Imhof 2013

\begin{tabular}{ll}
\hline Methods & Uncontrolled phase I study \\
\hline Participants & 15 participants with complete remission after primary therapy \\
\hline Interventions & Intradermal dendritic cells pulsed with mRNA (TERT) and short peptide (survivin) \\
\hline Outcomes & Immune responses (cellular) \\
& Adverse events \\
\hline
\end{tabular}


Imhof 2013 (Continued)

Notes

\section{Risk of bias}

\begin{tabular}{lll}
\hline Bias & Authors' judgement & Support for judgement \\
\hline $\begin{array}{l}\text { Random sequence genera- } \\
\text { tion (selection bias) }\end{array}$ & High risk & Uncontrolled trial \\
\hline
\end{tabular}

\begin{tabular}{ll}
\hline $\begin{array}{l}\text { Allocation concealment } \\
\text { (selection bias) }\end{array}$ & High risk
\end{tabular}

Blinding of participants Unclear risk Information insufficient to permit judgement of 'low risk' or 'high risk'
and personnel (perfor-

mance bias)

All outcomes

Blinding of outcome as- Unclear risk Information insufficient to permit judgement of 'low risk' or 'high risk'

sessment (detection bias)

All outcomes

Incomplete outcome data Unclear risk Information insufficient to permit judgement of 'low risk' or 'high risk'
(attrition bias)

All outcomes

Selective reporting (re- Unclear risk Information insufficient to permit judgement of 'low risk' or 'high risk'
porting bias)

\begin{tabular}{ll}
\hline Other bias $\quad$ Unclear risk Information insufficient to permit judgement of 'low risk' or 'high risk' \\
\hline
\end{tabular}

Kaumaya 2009

\begin{tabular}{ll}
\hline Methods & Uncontrolled phase I study \\
\hline Participants & 24 participants with metastatic and/or recurrent solid tumours (ovarian cancer $n=5)$ \\
\hline Interventions & Intramuscular synthetic long peptides (Her2) \\
& Adjuvant: Montanide ISA720 \\
\hline Outcomes & Tumour responses \\
& Immune responses (humoral) \\
\hline Notes & Adverse events \\
\hline Risk of bias & Authors' judgement Support for judgement \\
\hline Bias & High risk \\
\hline $\begin{array}{l}\text { Random sequence genera- } \\
\text { tion (selection bias) }\end{array}$ & Uncontrolled trial \\
\hline
\end{tabular}


Kaumaya 2009 (Continued)

\begin{tabular}{|c|c|c|}
\hline $\begin{array}{l}\text { Allocation concealment } \\
\text { (selection bias) }\end{array}$ & High risk & Uncontrolled trial \\
\hline $\begin{array}{l}\text { Blinding of participants } \\
\text { and personnel (perfor- } \\
\text { mance bias) } \\
\text { All outcomes }\end{array}$ & Unclear risk & Information insufficient to permit judgement of 'low risk' or 'high risk' \\
\hline $\begin{array}{l}\text { Blinding of outcome as- } \\
\text { sessment (detection bias) } \\
\text { All outcomes }\end{array}$ & Unclear risk & Information insufficient to permit judgement of 'low risk' or 'high risk' \\
\hline $\begin{array}{l}\text { Incomplete outcome data } \\
\text { (attrition bias) } \\
\text { All outcomes }\end{array}$ & Unclear risk & Information insufficient to permit judgement of 'low risk' or 'high risk' \\
\hline $\begin{array}{l}\text { Selective reporting (re- } \\
\text { porting bias) }\end{array}$ & Unclear risk & Information insufficient to permit judgement of 'low risk' or 'high risk' \\
\hline Other bias & Unclear risk & Information insufficient to permit judgement of 'low risk' or 'high risk' \\
\hline
\end{tabular}

\begin{tabular}{ll} 
Kawano 2014 & Uncontrolled phase II study \\
\hline Methods & $\begin{array}{l}42 \text { participants with platinum-sensitive }(\mathrm{n}=17) \text { and platinum-resistant }(\mathrm{n}=25) \text { recurrent ovarian can- } \\
\text { cer }\end{array}$ \\
\hline Interventions & $\begin{array}{l}\text { Personalised peptide vaccine }(\mathrm{PPV}) \text {; max of } 4 \text { peptides out of } 31 \text { different vaccine candidates + Mon- } \\
\text { tanide } \pm \text { chemotherapy }\end{array}$ \\
\hline Outcomes & Safety \\
& Immune response \\
Clinical response
\end{tabular}

\section{Notes}

\section{Risk of bias}

\begin{tabular}{lll}
\hline Bias & Authors' judgement & Support for judgement \\
\hline $\begin{array}{l}\text { Random sequence genera- } \\
\text { tion (selection bias) }\end{array}$ & High risk & Uncontrolled trial \\
\hline $\begin{array}{l}\text { Allocation concealment } \\
\text { (selection bias) }\end{array}$ & High risk & Uncontrolled trial \\
\hline $\begin{array}{l}\text { Blinding of participants } \\
\text { and personnel (perfor- } \\
\text { mance bias) }\end{array}$ & Unclear risk & Information insufficient to permit judgement of 'low risk' or 'high risk' \\
$\begin{array}{l}\text { All outcomes } \\
\begin{array}{l}\text { Blinding of outcome as- } \\
\text { sessment (detection bias) }\end{array}\end{array}$ & Unclear risk & Information insufficient to permit judgement of 'low risk' or 'high risk' \\
\hline
\end{tabular}


Kawano 2014 (Continued)

All outcomes

Incomplete outcome data Unclear risk Information insufficient to permit judgement of 'low risk' or 'high risk'
(attrition bias)
(attrition bias)

All outcomes

\begin{tabular}{lll}
\hline $\begin{array}{l}\text { Selective reporting (re- } \\
\text { porting bias) }\end{array}$ & Unclear risk & Information insufficient to permit judgement of 'low risk' or 'high risk' \\
\hline Other bias & Unclear risk & Information insufficient to permit judgement of 'low risk' or 'high risk' \\
\hline
\end{tabular}

Kobayashi 2014

\begin{tabular}{ll}
\hline Methods & Uncontrolled phase I/II or retrospective? \\
\hline Participants & 56 participants who received chemotherapy for recurrent ovarian carcinoma \\
\hline Interventions & Peptide pulsed DC vaccine (WT-1 \pm MUC1 \pm CA-12) + OK-432 \\
\hline Outcomes & Safety \\
& Immune response \\
& Clinical response \\
\hline Notes &
\end{tabular}

\section{Risk of bias}

\begin{tabular}{|c|c|c|}
\hline Bias & Authors' judgement & Support for judgement \\
\hline $\begin{array}{l}\text { Random sequence genera- } \\
\text { tion (selection bias) }\end{array}$ & High risk & Uncontrolled trial \\
\hline $\begin{array}{l}\text { Allocation concealment } \\
\text { (selection bias) }\end{array}$ & High risk & Uncontrolled trial \\
\hline $\begin{array}{l}\text { Blinding of participants } \\
\text { and personnel (perfor- } \\
\text { mance bias) } \\
\text { All outcomes }\end{array}$ & Unclear risk & Information insufficient to permit judgement of 'low risk' or 'high risk' \\
\hline $\begin{array}{l}\text { Blinding of outcome as- } \\
\text { sessment (detection bias) } \\
\text { All outcomes }\end{array}$ & Unclear risk & Information insufficient to permit judgement of 'low risk' or 'high risk' \\
\hline $\begin{array}{l}\text { Incomplete outcome data } \\
\text { (attrition bias) } \\
\text { All outcomes }\end{array}$ & Unclear risk & Information insufficient to permit judgement of 'low risk' or 'high risk' \\
\hline $\begin{array}{l}\text { Selective reporting (re- } \\
\text { porting bias) }\end{array}$ & Unclear risk & Information insufficient to permit judgement of 'low risk' or 'high risk' \\
\hline Other bias & Unclear risk & Information insufficient to permit judgement of 'low risk' or 'high risk' \\
\hline
\end{tabular}


Le 2012

\begin{tabular}{ll}
\hline Methods & Uncontrolled phase I study \\
\hline Participants & 17 participants with advanced cancers after prior therapy (ovarian cancer $\mathrm{n}=2)$ \\
\hline Interventions & Intravenous recombinant listeria (mesothelin) \\
\hline Outcomes & Immune responses (cellular) \\
& Adverse events \\
\hline
\end{tabular}

\section{Notes}

\section{Risk of bias}

\begin{tabular}{|c|c|c|}
\hline Bias & Authors' judgement & Support for judgement \\
\hline $\begin{array}{l}\text { Random sequence genera- } \\
\text { tion (selection bias) }\end{array}$ & High risk & Uncontrolled trial \\
\hline $\begin{array}{l}\text { Allocation concealment } \\
\text { (selection bias) }\end{array}$ & High risk & Uncontrolled trial \\
\hline $\begin{array}{l}\text { Blinding of participants } \\
\text { and personnel (perfor- } \\
\text { mance bias) } \\
\text { All outcomes }\end{array}$ & Unclear risk & Information insufficient to permit judgement of 'low risk' or 'high risk' \\
\hline $\begin{array}{l}\text { Blinding of outcome as- } \\
\text { sessment (detection bias) } \\
\text { All outcomes }\end{array}$ & Unclear risk & Information insufficient to permit judgement of 'low risk' or 'high risk' \\
\hline $\begin{array}{l}\text { Incomplete outcome data } \\
\text { (attrition bias) } \\
\text { All outcomes }\end{array}$ & Unclear risk & Information insufficient to permit judgement of 'low risk' or 'high risk' \\
\hline $\begin{array}{l}\text { Selective reporting (re- } \\
\text { porting bias) }\end{array}$ & Unclear risk & Information insufficient to permit judgement of 'low risk' or 'high risk' \\
\hline Other bias & Unclear risk & Information insufficient to permit judgement of 'low risk' or 'high risk' \\
\hline
\end{tabular}

\section{Leffers 2009a}

\begin{tabular}{ll}
\hline Methods & Uncontrolled phase II study \\
\hline Participants & $\begin{array}{l}20 \text { women with epithelial ovarian cancer with (biochemical) recurrence not (yet) eligible for renewed } \\
\text { chemotherapy }\end{array}$ \\
\hline Interventions & Subcutaneous synthetic long peptides (p53) \\
& Adjuvant: Montanide ISA51 \\
\hline Outcomes & Survival (disease-specific survival) \\
& Tumour responses
\end{tabular}


Leffers 2009a (Continued)

Immune responses: humoral, cellular

Adverse events

\section{Notes}

\section{Risk of bias}

\begin{tabular}{|c|c|c|}
\hline Bias & Authors' judgement & Support for judgement \\
\hline $\begin{array}{l}\text { Random sequence genera- } \\
\text { tion (selection bias) }\end{array}$ & High risk & Uncontrolled trial \\
\hline $\begin{array}{l}\text { Allocation concealment } \\
\text { (selection bias) }\end{array}$ & High risk & Uncontrolled trial \\
\hline $\begin{array}{l}\text { Blinding of participants } \\
\text { and personnel (perfor- } \\
\text { mance bias) } \\
\text { All outcomes }\end{array}$ & Unclear risk & IInformation insufficient to permit judgement of 'low risk' or 'high risk' \\
\hline $\begin{array}{l}\text { Blinding of outcome as- } \\
\text { sessment (detection bias) } \\
\text { All outcomes }\end{array}$ & Unclear risk & Information insufficient to permit judgement of 'low risk' or 'high risk' \\
\hline $\begin{array}{l}\text { Incomplete outcome data } \\
\text { (attrition bias) } \\
\text { All outcomes }\end{array}$ & Unclear risk & Information insufficient to permit judgement of 'low risk' or 'high risk' \\
\hline $\begin{array}{l}\text { Selective reporting (re- } \\
\text { porting bias) }\end{array}$ & Unclear risk & Information insufficient to permit judgement of 'low risk' or 'high risk' \\
\hline Other bias & Unclear risk & Information insufficient to permit judgement of 'low risk' or 'high risk' \\
\hline
\end{tabular}

\section{Lennerz 2014}

\begin{tabular}{ll}
\hline Methods & Randomized phase I \\
\hline Participants & 49 participants with survivin expressing solid tumours (ovarian cancer $n=7)$ \\
\hline Interventions & $\begin{array}{l}\text { Three dosage groups of EMD640744 vaccine (5 HLA class I-binding survivin peptides in Montanide ISA } \\
62 \text { VG) }\end{array}$ \\
\hline Outcomes & Immune response \\
& Safety \\
& Clinical response \\
\hline
\end{tabular}

\section{Notes}

\section{Risk of bias}

Bias Authors' judgement Support for judgement


Lennerz 2014 (Continued)

Random sequence genera- Low risk Randomised between 3 dosage groups tion (selection bias)

\begin{tabular}{lll}
\hline $\begin{array}{l}\text { Allocation concealment } \\
\text { (selection bias) }\end{array}$ & Unclear risk & Randomised trial \\
\hline $\begin{array}{l}\text { Blinding of participants } \\
\text { and personnel (perfor- }\end{array}$ & High risk & Open-label study \\
mance bias) & & \\
All outcomes &
\end{tabular}

\begin{tabular}{|c|c|c|}
\hline $\begin{array}{l}\text { Blinding of outcome as- } \\
\text { sessment (detection bias) } \\
\text { All outcomes }\end{array}$ & High risk & Open-label study \\
\hline $\begin{array}{l}\text { Incomplete outcome data } \\
\text { (attrition bias) } \\
\text { All outcomes }\end{array}$ & Unclear risk & Information insufficient to permit judgement of 'low risk' or 'high risk' \\
\hline $\begin{array}{l}\text { Selective reporting (re- } \\
\text { porting bias) }\end{array}$ & Unclear risk & Information insufficient to permit judgement of 'low risk' or 'high risk' \\
\hline Other bias & Low risk & No other forms of bias detected \\
\hline
\end{tabular}

\section{Letsch 2011}

\begin{tabular}{ll}
\hline Methods & Uncontrolled study \\
\hline Participants & 18 participants with WT1-expressing solid tumours (disease status unreported) (ovarian cancer $\mathrm{n}=8$ ) \\
\hline Interventions & Short peptide (WT1) \\
& Adjuvant: KLH, GM-CSF \\
\hline Outcomes & Tumour responses \\
& Immune responses (cellular) \\
& Adverse events \\
\hline
\end{tabular}

Notes

\section{Risk of bias}

\begin{tabular}{lll}
\hline Bias & Authors' judgement & Support for judgement \\
\hline $\begin{array}{l}\text { Random sequence genera- } \\
\text { tion (selection bias) }\end{array}$ & High risk & Uncontrolled trial \\
\hline $\begin{array}{l}\text { Allocation concealment } \\
\text { (selection bias) }\end{array}$ & High risk & Uncontrolled trial \\
\hline $\begin{array}{l}\text { Blinding of participants } \\
\text { and personnel (perfor- } \\
\text { mance bias) } \\
\text { All outcomes }\end{array}$ & Unclear risk & Information insufficient to permit judgement of 'low risk' or 'high risk' \\
\hline \hline
\end{tabular}


Letsch 2011 (Continued)

Blinding of outcome as- Unclear risk Information insufficient to permit judgement of 'low risk' or 'high risk' sessment (detection bias)

All outcomes

Incomplete outcome data Unclear risk Information insufficient to permit judgement of 'low risk' or 'high risk'
(attrition bias)

All outcomes

\begin{tabular}{lll}
\hline $\begin{array}{l}\text { Selective reporting (re- } \\
\text { porting bias) }\end{array}$ & Unclear risk & Information insufficient to permit judgement of 'low risk' or 'high risk' \\
\hline Other bias & Unclear risk & Information insufficient to permit judgement of 'low risk' or 'high risk' \\
\hline
\end{tabular}

Ma 2002

\begin{tabular}{|c|c|c|}
\hline Methods & \multicolumn{2}{|l|}{ Uncontrolled study } \\
\hline Participants & \multicolumn{2}{|c|}{4 women with ovarian cancer (disease status at study entry not described) } \\
\hline Interventions & \multicolumn{2}{|c|}{ Monoclonal antibody (MJ01 - CA-125) } \\
\hline Outcomes & \multicolumn{2}{|c|}{ Immune response: cellular } \\
\hline \multicolumn{3}{|l|}{ Notes } \\
\hline \multicolumn{3}{|l|}{ Risk of bias } \\
\hline Bias & Authors' judgement & Support for judgement \\
\hline $\begin{array}{l}\text { Random sequence genera- } \\
\text { tion (selection bias) }\end{array}$ & High risk & Uncontrolled trial \\
\hline $\begin{array}{l}\text { Allocation concealment } \\
\text { (selection bias) }\end{array}$ & High risk & Uncontrolled trial \\
\hline $\begin{array}{l}\text { Blinding of participants } \\
\text { and personnel (perfor- } \\
\text { mance bias) } \\
\text { All outcomes }\end{array}$ & Unclear risk & Information insufficient to permit judgement of 'low risk' or 'high risk' \\
\hline $\begin{array}{l}\text { Blinding of outcome as- } \\
\text { sessment (detection bias) } \\
\text { All outcomes }\end{array}$ & Unclear risk & Information insufficient to permit judgement of 'low risk' or 'high risk' \\
\hline $\begin{array}{l}\text { Incomplete outcome data } \\
\text { (attrition bias) } \\
\text { All outcomes }\end{array}$ & Unclear risk & Information insufficient to permit judgement of 'low risk' or 'high risk' \\
\hline $\begin{array}{l}\text { Selective reporting (re- } \\
\text { porting bias) }\end{array}$ & Unclear risk & Information insufficient to permit judgement of 'low risk' or 'high risk' \\
\hline Other bias & Unclear risk & Information insufficient to permit judgement of 'low risk' or 'high risk' \\
\hline
\end{tabular}


MacLean 1992

\begin{tabular}{ll}
\hline Methods & Uncontrolled phase I study \\
\hline Participants & 10 women with ovarian cancer and residual or recurrent disease \\
\hline Interventions & Subcutaneous KLH conjugate (Thomsen Friedenreich) \\
\hline Outcomes & Adjuvant: Detox B \\
Immune responses: humoral \\
Adverse events
\end{tabular}

Notes

\section{Risk of bias}

\begin{tabular}{lll}
\hline Bias & Authors' judgement & Support for judgement \\
\hline $\begin{array}{l}\text { Random sequence genera- } \\
\text { tion (selection bias) }\end{array}$ & High risk & Uncontrolled trial \\
\hline $\begin{array}{l}\text { Allocation concealment } \\
\text { (selection bias) }\end{array}$ & High risk & Uncontrolled trial \\
\hline
\end{tabular}

\begin{tabular}{l}
\hline Blinding of participants Unclear risk Information insufficient to permit judgement of 'low risk' or 'high risk' \\
and personnel (perfor- \\
mance bias) \\
All outcomes
\end{tabular}

Blinding of outcome as- Unclear risk Information insufficient to permit judgement of 'low risk' or 'high risk' sessment (detection bias)

All outcomes

\begin{tabular}{lll}
\hline $\begin{array}{l}\text { Incomplete outcome data } \\
\text { (attrition bias) } \\
\text { All outcomes }\end{array}$ & Unclear risk & Information insufficient to permit judgement of 'low risk' or 'high risk' \\
\hline $\begin{array}{l}\text { Selective reporting (re- } \\
\text { porting bias) }\end{array}$ & Unclear risk & Information insufficient to permit judgement of 'low risk' or 'high risk' \\
\hline Other bias & Unclear risk & Information insufficient to permit judgement of 'low risk' or 'high risk' \\
\hline
\end{tabular}

\begin{tabular}{ll}
\hline MacLean 1996 & Uncontrolled phase II study \\
\hline Participants & 34 women with ovarian cancer and evaluable residual or recurrent disease \\
\hline Interventions & Subcutaneous KLH conjugate (Sialyl-Tn) \\
& Adjuvant: Detox B \\
\hline Outcomes & Survival (trial entry to death)
\end{tabular}


MacLean 1996 (Continued)

Immune response: humoral

\section{Notes}

\section{Risk of bias}

\begin{tabular}{|c|c|c|}
\hline Bias & Authors' judgement & Support for judgement \\
\hline $\begin{array}{l}\text { Random sequence genera- } \\
\text { tion (selection bias) }\end{array}$ & High risk & Uncontrolled trial \\
\hline $\begin{array}{l}\text { Allocation concealment } \\
\text { (selection bias) }\end{array}$ & High risk & Uncontrolled trial \\
\hline $\begin{array}{l}\text { Blinding of participants } \\
\text { and personnel (perfor- } \\
\text { mance bias) } \\
\text { All outcomes }\end{array}$ & Unclear risk & Information insufficient to permit judgement of 'low risk' or 'high risk' \\
\hline $\begin{array}{l}\text { Blinding of outcome as- } \\
\text { sessment (detection bias) } \\
\text { All outcomes }\end{array}$ & Unclear risk & Information insufficient to permit judgement of 'low risk' or 'high risk' \\
\hline $\begin{array}{l}\text { Incomplete outcome data } \\
\text { (attrition bias) } \\
\text { All outcomes }\end{array}$ & Unclear risk & Information insufficient to permit judgement of 'low risk' or 'high risk' \\
\hline $\begin{array}{l}\text { Selective reporting (re- } \\
\text { porting bias) }\end{array}$ & Unclear risk & Information insufficient to permit judgement of 'low risk' or 'high risk' \\
\hline Other bias & Unclear risk & Information insufficient to permit judgement of 'low risk' or 'high risk' \\
\hline
\end{tabular}

\section{Method 2002}

\begin{tabular}{|c|c|c|}
\hline Methods & \multicolumn{2}{|c|}{ Randomised controlled study } \\
\hline Participants & \multicolumn{2}{|c|}{102 women with ovarian cancer after primary therapy (disease status at study entry not described) } \\
\hline Interventions & \multicolumn{2}{|c|}{ Intravenous monoclonal antibody (oregovomab - CA-125): 2 gifts vs 3 gifts vs 6 gifts } \\
\hline \multirow[t]{3}{*}{ Outcomes } & \multicolumn{2}{|l|}{ Tumour responses } \\
\hline & \multicolumn{2}{|c|}{ Immune response: humoral (Ab2, HAMA), cellular } \\
\hline & \multicolumn{2}{|l|}{ Adverse events } \\
\hline \multicolumn{3}{|l|}{ Notes } \\
\hline \multicolumn{3}{|l|}{ Risk of bias } \\
\hline Bias & Authors' judgement & Support for judgement \\
\hline $\begin{array}{l}\text { Random sequence genera- } \\
\text { tion (selection bias) }\end{array}$ & Unclear risk & $\begin{array}{l}\text { Information about the sequence generation process insufficient to permit } \\
\text { judgement of 'low risk' or 'high risk'; only abstract available }\end{array}$ \\
\hline
\end{tabular}


Method 2002 (Continued)

\begin{tabular}{|c|c|c|}
\hline $\begin{array}{l}\text { Allocation concealment } \\
\text { (selection bias) }\end{array}$ & Unclear risk & $\begin{array}{l}\text { Information insufficient to permit judgement of 'low risk' or 'high risk'; only } \\
\text { abstract available }\end{array}$ \\
\hline
\end{tabular}
(selection bias)

Low risk

Blinding of participants and personnel (performance bias)

All outcomes

\section{Blinding of outcome as- Unclear risk} sessment (detection bias)

All outcomes

\begin{tabular}{|c|c|c|}
\hline $\begin{array}{l}\text { Incomplete outcome data } \\
\text { (attrition bias) } \\
\text { All outcomes }\end{array}$ & Unclear risk & $\begin{array}{l}\text { Reporting of attrition/exclusions insufficient to permit judgement of 'low risk' } \\
\text { or 'high risk'; only abstract available }\end{array}$ \\
\hline $\begin{array}{l}\text { Selective reporting (re- } \\
\text { porting bias) }\end{array}$ & Unclear risk & $\begin{array}{l}\text { Information insufficient to permit judgement of 'low risk' or 'high risk'; only } \\
\text { abstract available }\end{array}$ \\
\hline Other bias & Unclear risk & $\begin{array}{l}\text { Information insufficient to permit judgement of 'low risk' or 'high risk'; only } \\
\text { abstract available }\end{array}$ \\
\hline
\end{tabular}

No blinding or incomplete blinding, but review authors judge that the outcome is not likely to be influenced by lack of blinding

Mohebtash 2011

\begin{tabular}{|c|c|c|}
\hline Methods & \multicolumn{2}{|l|}{ Uncontrolled study } \\
\hline Participants & \multicolumn{2}{|c|}{31 metastatic ovarian and breast cancer patients (ovarian cancer $n=14$ ) } \\
\hline Interventions & \multicolumn{2}{|c|}{ Subcutaneous recombinant pox virus (MUC1 and CEA) } \\
\hline & \multicolumn{2}{|l|}{ Adjuvant: local GM-CSF } \\
\hline \multirow[t]{3}{*}{ Outcomes } & \multicolumn{2}{|c|}{ Survival: median time to progression 2 months (range 1 to 36 ) } \\
\hline & \multicolumn{2}{|c|}{ Immune responses (cellular) } \\
\hline & \multicolumn{2}{|c|}{ Adverse events: no severe adverse events, mostly locoregional grade 1 or 2 reactions } \\
\hline Notes & \multicolumn{2}{|c|}{ Max 3 patients overlap with Gulley 2008} \\
\hline \multicolumn{3}{|l|}{ Risk of bias } \\
\hline Bias & Authors' judgement & Support for judgement \\
\hline $\begin{array}{l}\text { Random sequence genera- } \\
\text { tion (selection bias) }\end{array}$ & High risk & Uncontrolled trial \\
\hline $\begin{array}{l}\text { Allocation concealment } \\
\text { (selection bias) }\end{array}$ & High risk & Uncontrolled trial \\
\hline $\begin{array}{l}\text { Blinding of participants } \\
\text { and personnel (perfor- } \\
\text { mance bias) } \\
\text { All outcomes }\end{array}$ & Unclear risk & Information insufficient to permit judgement of 'low risk' or 'high risk' \\
\hline
\end{tabular}


Mohebtash 2011 (Continued)

Blinding of outcome as- Unclear risk Information insufficient to permit judgement of 'low risk' or 'high risk' sessment (detection bias)

All outcomes

Incomplete outcome data Unclear risk Information insufficient to permit judgement of 'low risk' or 'high risk'
(attrition bias)

(attrition bias)

All outcomes

\begin{tabular}{|c|c|c|}
\hline $\begin{array}{l}\text { Selective reporting (re- } \\
\text { porting bias) }\end{array}$ & Unclear risk & Information insufficient to permit judgement of 'low risk' or 'high risk' \\
\hline
\end{tabular}

\begin{tabular}{ll}
\hline Other bias Unclear risk Information insufficient to permit judgement of 'low risk' or 'high risk' \\
\hline
\end{tabular}

Morse 2011

\begin{tabular}{ll}
\hline Methods & Uncontrolled phase I study \\
\hline Participants & $\begin{array}{l}15 \text { ovarian and breast cancer patients with no evidence of disease after prior therapy (ovarian cancer } \mathrm{n} \\
=8)\end{array}$ \\
\hline $\begin{array}{l}\text { Intradermal and subcutaneous short peptides in 2 groups (group 1: APC, HHR6, BAP31, replication } \\
\text { protein A, Abl-binding protein 3c, cyclin I; group 2: topoisomerase Ila/ } \beta \text {, integrin } \beta \text { 8 subunit precursor, } \\
\text { CDC2, TACE, g-catenin, EEDDR1) }\end{array}$ \\
Adjuvant: Montanide ISA-51, GM-CSF \\
\hline Outcomes & Survival \\
Immune responses: cellular \\
Adverse events
\end{tabular}

\section{Risk of bias}

\begin{tabular}{|c|c|c|}
\hline Bias & Authors' judgement & Support for judgement \\
\hline $\begin{array}{l}\text { Random sequence genera- } \\
\text { tion (selection bias) }\end{array}$ & High risk & Uncontrolled trial \\
\hline $\begin{array}{l}\text { Allocation concealment } \\
\text { (selection bias) }\end{array}$ & High risk & Uncontrolled trial \\
\hline $\begin{array}{l}\text { Blinding of participants } \\
\text { and personnel (perfor- } \\
\text { mance bias) } \\
\text { All outcomes }\end{array}$ & Unclear risk & Information insufficient to permit judgement of 'low risk' or 'high risk' \\
\hline $\begin{array}{l}\text { Blinding of outcome as- } \\
\text { sessment (detection bias) } \\
\text { All outcomes }\end{array}$ & Unclear risk & Information insufficient to permit judgement of 'low risk' or 'high risk' \\
\hline $\begin{array}{l}\text { Incomplete outcome data } \\
\text { (attrition bias) } \\
\text { All outcomes }\end{array}$ & Unclear risk & Information insufficient to permit judgement of 'low risk' or 'high risk' \\
\hline
\end{tabular}


Morse 2011 (Continued)

Selective reporting (re- Unclear risk Information insufficient to permit judgement of 'low risk' or 'high risk' porting bias)

Other bias Unclear risk Information insufficient to permit judgement of 'low risk' or 'high risk'

Möbus 2003

\begin{tabular}{ll}
\hline Methods & Retrospective uncontrolled study \\
\hline Participants & 44 ovarian cancer patients with clinical recurrence after primary therapy \\
\hline Interventions & Intravenous monoclonal antibody (oregovomab - CA-125) \\
\hline Outcomes & Survival (time from first dose to death/overall survival) \\
Immune response: humoral (Ab2, Ab3, HAMA) \\
Adverse events
\end{tabular}

Notes

\section{Risk of bias}

\begin{tabular}{|c|c|c|}
\hline Bias & Authors' judgement & Support for judgement \\
\hline $\begin{array}{l}\text { Random sequence genera- } \\
\text { tion (selection bias) }\end{array}$ & High risk & Uncontrolled trial \\
\hline $\begin{array}{l}\text { Allocation concealment } \\
\text { (selection bias) }\end{array}$ & High risk & Uncontrolled trial \\
\hline $\begin{array}{l}\text { Blinding of participants } \\
\text { and personnel (perfor- } \\
\text { mance bias) } \\
\text { All outcomes }\end{array}$ & Unclear risk & Information insufficient to permit judgement of 'low risk' or 'high risk' \\
\hline $\begin{array}{l}\text { Blinding of outcome as- } \\
\text { sessment (detection bias) } \\
\text { All outcomes }\end{array}$ & Unclear risk & Information insufficient to permit judgement of 'low risk' or 'high risk' \\
\hline $\begin{array}{l}\text { Incomplete outcome data } \\
\text { (attrition bias) } \\
\text { All outcomes }\end{array}$ & Unclear risk & Information insufficient to permit judgement of 'low risk' or 'high risk' \\
\hline $\begin{array}{l}\text { Selective reporting (re- } \\
\text { porting bias) }\end{array}$ & Unclear risk & Information insufficient to permit judgement of 'low risk' or 'high risk' \\
\hline Other bias & Unclear risk & Information insufficient to permit judgement of 'low risk' or 'high risk' \\
\hline
\end{tabular}

Nicholson 2004

\begin{tabular}{ll}
\hline Methods Uncontrolled phase I study \\
\hline
\end{tabular}


Nicholson 2004 (Continued)

Participants 26 epithelial ovarian cancer patients with residual disease $(n=19)$, microscopic disease $(n=3)$ after chemotherapy, or second complete remission $(n=4)$

Interventions

Monoclonal antibody (HMFG1 - MUC1); first gift intraperitoneal $(n=16)$ or intravenous $(n=10)$, then ID boosts

Adjuvant: aluminium hydroxide

\begin{tabular}{ll}
\hline Outcomes & Tumour responses \\
Immune response: humoral (Ab2) \\
Adverse events
\end{tabular}

\section{Notes}

\section{Risk of bias}

\begin{tabular}{|c|c|c|}
\hline Bias & Authors' judgement & Support for judgement \\
\hline $\begin{array}{l}\text { Random sequence genera- } \\
\text { tion (selection bias) }\end{array}$ & High risk & Uncontrolled trial \\
\hline $\begin{array}{l}\text { Allocation concealment } \\
\text { (selection bias) }\end{array}$ & High risk & Uncontrolled trial \\
\hline $\begin{array}{l}\text { Blinding of participants } \\
\text { and personnel (perfor- } \\
\text { mance bias) } \\
\text { All outcomes }\end{array}$ & Unclear risk & Information insufficient to permit judgement of 'low risk' or 'high risk' \\
\hline $\begin{array}{l}\text { Blinding of outcome as- } \\
\text { sessment (detection bias) } \\
\text { All outcomes }\end{array}$ & Unclear risk & Information insufficient to permit judgement of 'low risk' or 'high risk' \\
\hline $\begin{array}{l}\text { Incomplete outcome data } \\
\text { (attrition bias) } \\
\text { All outcomes }\end{array}$ & Unclear risk & Information insufficient to permit judgement of 'low risk' or 'high risk' \\
\hline $\begin{array}{l}\text { Selective reporting (re- } \\
\text { porting bias) }\end{array}$ & Unclear risk & Information insufficient to permit judgement of 'low risk' or 'high risk' \\
\hline Other bias & Unclear risk & Information insufficient to permit judgement of 'low risk' or 'high risk' \\
\hline
\end{tabular}

Nishikawa 2006

\begin{tabular}{ll}
\hline Methods & Uncontrolled phase Il study \\
\hline Participants & $\begin{array}{l}\text { 4 epithelial ovarian cancer patients after primary debulking surgery (disease status at study entry not } \\
\text { described) }\end{array}$ \\
\hline Interventions & Short peptide (NY-ESO-1) \\
& Adjuvant: incomplete Freund's adjuvant \\
\hline Outcomes & Immune responses: cellular \\
\hline
\end{tabular}


Nishikawa 2006 (Continued)

Notes

\section{Risk of bias}

\begin{tabular}{|c|c|c|}
\hline Bias & Authors' judgement & Support for judgement \\
\hline $\begin{array}{l}\text { Random sequence genera- } \\
\text { tion (selection bias) }\end{array}$ & High risk & Uncontrolled trial \\
\hline $\begin{array}{l}\text { Allocation concealment } \\
\text { (selection bias) }\end{array}$ & High risk & Uncontrolled trial \\
\hline $\begin{array}{l}\text { Blinding of participants } \\
\text { and personnel (perfor- } \\
\text { mance bias) } \\
\text { All outcomes }\end{array}$ & Unclear risk & Information insufficient to permit judgement of 'low risk' or 'high risk' \\
\hline $\begin{array}{l}\text { Blinding of outcome as- } \\
\text { sessment (detection bias) } \\
\text { All outcomes }\end{array}$ & Unclear risk & Information insufficient to permit judgement of 'low risk' or 'high risk' \\
\hline $\begin{array}{l}\text { Incomplete outcome data } \\
\text { (attrition bias) } \\
\text { All outcomes }\end{array}$ & Unclear risk & Information insufficient to permit judgement of 'low risk' or 'high risk' \\
\hline $\begin{array}{l}\text { Selective reporting (re- } \\
\text { porting bias) }\end{array}$ & Unclear risk & Information insufficient to permit judgement of 'low risk' or 'high risk' \\
\hline Other bias & Unclear risk & Information insufficient to permit judgement of 'low risk' or 'high risk'\&\& \\
\hline
\end{tabular}

Noujaim 2001

\begin{tabular}{|c|c|c|}
\hline Methods & \multicolumn{2}{|c|}{ Retrospective uncontrolled study } \\
\hline Participants & \multicolumn{2}{|c|}{184 ovarian cancer patients with clinically or radiologically suspected recurrence } \\
\hline Interventions & \multicolumn{2}{|c|}{ Intravenous monoclonal antibody (oregovomab - CA-125) } \\
\hline Outcomes & \multicolumn{2}{|c|}{ Survival (overall survival) } \\
\hline & \multicolumn{2}{|c|}{ Immune responses: humoral (Ab3), cellular } \\
\hline \multicolumn{3}{|l|}{ Notes } \\
\hline \multicolumn{3}{|l|}{ Risk of bias } \\
\hline Bias & Authors' judgement & Support for judgement \\
\hline $\begin{array}{l}\text { Random sequence genera- } \\
\text { tion (selection bias) }\end{array}$ & High risk & Uncontrolled trial \\
\hline $\begin{array}{l}\text { Allocation concealment } \\
\text { (selection bias) }\end{array}$ & High risk & Uncontrolled trial \\
\hline
\end{tabular}


Noujaim 2001 (Continued)

Blinding of participants Unclear risk Information insufficient to permit judgement of 'low risk' or 'high risk' and personnel (performance bias)

All outcomes

\begin{tabular}{|c|c|c|}
\hline $\begin{array}{l}\text { Blinding of outcome as- } \\
\text { sessment (detection bias) }\end{array}$ & Unclear risk & Information insufficient to permit judgement of 'low risk' or 'high risk' \\
\hline
\end{tabular}

All outcomes

Incomplete outcome data Unclear risk Information insufficient to permit judgement of 'low risk' or 'high risk'
(attrition bias)

Selective reporting (re- Unclear risk Information insufficient to permit judgement of 'low risk' or 'high risk'
porting bias)

porting bias)

Other bias Unclear risk Information insufficient to permit judgement of 'low risk' or 'high risk'

O'Cearbhaill 2016

\begin{tabular}{ll}
\hline Methods & Uncontrolled phase I \\
\hline Participants & 24 participants with advanced-stage, first-remission ovarian cancer \\
\hline Interventions & Dose escalation - 25, 50, $100 \mathrm{mcg}$ - unimolecular pentavalent carbohydrate vaccine (Globo-H, GM2, sTn, \\
& TF and Tn in QS-21) \\
\hline Outcomes & Safety \\
& Immune response \\
\hline
\end{tabular}

Notes

\section{Risk of bias}

\begin{tabular}{|c|c|c|}
\hline Bias & Authors' judgement & Support for judgement \\
\hline $\begin{array}{l}\text { Random sequence genera- } \\
\text { tion (selection bias) }\end{array}$ & High risk & Uncontrolled trial \\
\hline $\begin{array}{l}\text { Allocation concealment } \\
\text { (selection bias) }\end{array}$ & High risk & Uncontrolled trial \\
\hline $\begin{array}{l}\text { Blinding of participants } \\
\text { and personnel (perfor- } \\
\text { mance bias) } \\
\text { All outcomes }\end{array}$ & Unclear risk & Information insufficient to permit judgement of 'low risk' or 'high risk' \\
\hline $\begin{array}{l}\text { Blinding of outcome as- } \\
\text { sessment (detection bias) } \\
\text { All outcomes }\end{array}$ & Unclear risk & Information insufficient to permit judgement of 'low risk' or 'high risk' \\
\hline $\begin{array}{l}\text { Incomplete outcome data } \\
\text { (attrition bias) } \\
\text { All outcomes }\end{array}$ & Unclear risk & Information insufficient to permit judgement of 'low risk' or 'high risk' \\
\hline
\end{tabular}


O'Cearbhaill 2016 (Continued)

Selective reporting (re- Unclear risk Information insufficient to permit judgement of 'low risk' or 'high risk' porting bias)

Other bias Unclear risk Information insufficient to permit judgement of 'low risk' or 'high risk'

\section{Odunsi 2007}

\begin{tabular}{ll}
\hline Methods & Uncontrolled phase I study \\
\hline Participants & $\begin{array}{l}18 \text { ovarian cancer patients after chemotherapy for primary or recurrent disease with or without resid- } \\
\text { ual disease }\end{array}$ \\
\hline Interventions & Subcutaneous short peptide (NY-ESO-1) \\
& Adjuvant: incomplete Freund's adjuvant \\
\hline Outcomes & Survival: median time to progression: 19.0 months \\
& Tumour responses: $1 \times$ CR, $17 \times$ unknown \\
Immune responses: humoral, cellular \\
Adverse events: well tolerated, no further description
\end{tabular}

\section{Notes}

\section{Risk of bias}

\begin{tabular}{|c|c|c|}
\hline Bias & Authors' judgement & Support for judgement \\
\hline $\begin{array}{l}\text { Random sequence genera- } \\
\text { tion (selection bias) }\end{array}$ & High risk & Uncontrolled trial \\
\hline $\begin{array}{l}\text { Allocation concealment } \\
\text { (selection bias) }\end{array}$ & High risk & Uncontrolled trial \\
\hline $\begin{array}{l}\text { Blinding of participants } \\
\text { and personnel (perfor- } \\
\text { mance bias) } \\
\text { All outcomes }\end{array}$ & Unclear risk & Information insufficient to permit judgement of 'low risk' or 'high risk' \\
\hline $\begin{array}{l}\text { Blinding of outcome as- } \\
\text { sessment (detection bias) } \\
\text { All outcomes }\end{array}$ & Unclear risk & Information insufficient to permit judgement of 'low risk' or 'high risk' \\
\hline $\begin{array}{l}\text { Incomplete outcome data } \\
\text { (attrition bias) } \\
\text { All outcomes }\end{array}$ & Unclear risk & Information insufficient to permit judgement of 'low risk' or 'high risk' \\
\hline $\begin{array}{l}\text { Selective reporting (re- } \\
\text { porting bias) }\end{array}$ & Unclear risk & Information insufficient to permit judgement of 'low risk' or 'high risk' \\
\hline Other bias & Unclear risk & Information insufficient to permit judgement of 'low risk' or 'high risk' \\
\hline
\end{tabular}


Odunsi 2012

\begin{tabular}{ll}
\hline Methods & Uncontrolled phase I/II study \\
\hline Participants & 22 women with ovarian cancer without evidence of disease after primary therapy \\
\hline Interventions & intradermal recombinant virus (NY-ESO-1); $1 \times$ vaccinia virus, $6 \times$ fowlpox boost \\
\hline Outcomes & Survival (disease-free survival) \\
& Immune responses: humoral, cellular \\
& Adverse events \\
\hline
\end{tabular}

Notes

\section{Risk of bias}

\begin{tabular}{|c|c|c|}
\hline Bias & Authors' judgement & Support for judgement \\
\hline $\begin{array}{l}\text { Random sequence genera- } \\
\text { tion (selection bias) }\end{array}$ & High risk & Uncontrolled trial \\
\hline $\begin{array}{l}\text { Allocation concealment } \\
\text { (selection bias) }\end{array}$ & High risk & Uncontrolled trial \\
\hline $\begin{array}{l}\text { Blinding of participants } \\
\text { and personnel (perfor- } \\
\text { mance bias) } \\
\text { All outcomes }\end{array}$ & Unclear risk & Information insufficient to permit judgement of 'low risk' or 'high risk' \\
\hline $\begin{array}{l}\text { Blinding of outcome as- } \\
\text { sessment (detection bias) } \\
\text { All outcomes }\end{array}$ & Unclear risk & Information insufficient to permit judgement of 'low risk' or 'high risk' \\
\hline $\begin{array}{l}\text { Incomplete outcome data } \\
\text { (attrition bias) } \\
\text { All outcomes }\end{array}$ & Unclear risk & Information insufficient to permit judgement of 'low risk' or 'high risk' \\
\hline $\begin{array}{l}\text { Selective reporting (re- } \\
\text { porting bias) }\end{array}$ & Unclear risk & Information insufficient to permit judgement of 'low risk' or 'high risk' \\
\hline Other bias & Unclear risk & Information insufficient to permit judgement of 'low risk' or 'high risk' \\
\hline
\end{tabular}

Odunsi 2014

\begin{tabular}{ll}
\hline Methods & Uncontrolled phase I/II dose escalation trial \\
\hline Participants & 12 participants with recurrent epithelial ovarian cancer \\
\hline Interventions & C1: day 1 decitabine $\left(45 \mathrm{mg} / \mathrm{m}^{2}\right)$, day 8 doxorubicin $\left(40 \mathrm{mg} / \mathrm{m}^{2}\right)$, day $15 \mathrm{NY-ESO-I} \mathrm{vaccine}$ \\
& C2: day 1 decitabine $\left(90 \mathrm{mg} / \mathrm{m}^{2}\right)$, day 8 doxorubicin $\left(40 \mathrm{mg} / \mathrm{m}^{2}\right)$, day 15 NY-ESO-I vaccine \\
C3: days 1 to 5 decitabine $\left(10 \mathrm{mg} / \mathrm{m}^{2}\right)$, day 8 doxorubicin $\left(40 \mathrm{mg} / \mathrm{m}^{2}\right)$, day 15 NY-ESO-I vaccine \\
\hline
\end{tabular}


Odunsi 2014 (Continued)

Clinical response

Notes

\section{Risk of bias}

\begin{tabular}{|c|c|c|}
\hline Bias & Authors' judgement & Support for judgement \\
\hline $\begin{array}{l}\text { Random sequence genera- } \\
\text { tion (selection bias) }\end{array}$ & High risk & Uncontrolled trial \\
\hline $\begin{array}{l}\text { Allocation concealment } \\
\text { (selection bias) }\end{array}$ & High risk & Uncontrolled trial \\
\hline $\begin{array}{l}\text { Blinding of participants } \\
\text { and personnel (perfor- } \\
\text { mance bias) } \\
\text { All outcomes }\end{array}$ & High risk & Open-label study \\
\hline $\begin{array}{l}\text { Blinding of outcome as- } \\
\text { sessment (detection bias) } \\
\text { All outcomes }\end{array}$ & High risk & Open-label study \\
\hline $\begin{array}{l}\text { Incomplete outcome data } \\
\text { (attrition bias) } \\
\text { All outcomes }\end{array}$ & Unclear risk & Information insufficient to permit judgement of 'low risk' or 'high risk' \\
\hline $\begin{array}{l}\text { Selective reporting (re- } \\
\text { porting bias) }\end{array}$ & Unclear risk & Information insufficient to permit judgement of 'low risk' or 'high risk' \\
\hline Other bias & Unclear risk & Information insufficient to permit judgement of 'low risk' or 'high risk' \\
\hline
\end{tabular}

Ohno 2009

\begin{tabular}{ll}
\hline Methods & Uncontrolled phase II study \\
\hline Participants & 12 patients with gynaecological malignancies resistant to standard therapy (ovarian cancer $\mathrm{n}=6$ ) \\
\hline Interventions & Intradermal short peptide (WT1) \\
& Adjuvant: Montanide ISA-51 \\
\hline Outcomes & Tumour responses \\
\hline Notes &
\end{tabular}

\section{Risk of bias}

\begin{tabular}{lll}
\hline Bias & Authors' judgement & Support for judgement \\
\hline $\begin{array}{l}\text { Random sequence genera- } \\
\text { tion (selection bias) }\end{array}$ & High risk & Uncontrolled trial \\
\hline $\begin{array}{l}\text { Allocation concealment } \\
\text { (selection bias) }\end{array}$ & High risk & Uncontrolled trial \\
\hline
\end{tabular}


Ohno 2009 (Continued)

Blinding of participants Unclear risk Information insufficient to permit judgement of 'low risk' or 'high risk' and personnel (perfor-

mance bias)

All outcomes

Blinding of outcome as-
sessment (detection bias) $\quad$ Unclear risk Information insufficient to permit judgement of 'low risk' or 'high risk'

All outcomes

Incomplete outcome data Unclear risk

Information insufficient to permit judgement of 'low risk' or 'high risk'

(attrition bias)

Unclear risk

All outcomes

$\begin{aligned} & \text { Selective reporting (re- } \quad \text { Unclear risk Information insufficient to permit judgement of 'low risk' or 'high risk' } \\ & \text { porting bias) }\end{aligned}$

Other bias Unclear risk Information insufficient to permit judgement of 'low risk' or 'high risk'

Peethambaram 2009

\begin{tabular}{ll}
\hline Methods & Uncontrolled phase I study \\
\hline Participants & 18 patients with refractory metastatic tumours (ovarian cancer $\mathrm{n}=4$ ) \\
\hline Interventions & Intravenous recombinant fusion antigen pulsed antigen-presenting cells (Her-2/Neu) \\
& Adjuvant: GM-CSF (included in the recombinant fusion product) \\
\hline Outcomes & Survival (time to progression) \\
& Tumour responses \\
& Immune responses: cellular \\
& Adverse events \\
\hline Notes & \\
\hline
\end{tabular}

\section{Risk of bias}

\begin{tabular}{|c|c|c|}
\hline Bias & Authors' judgement & Support for judgement \\
\hline $\begin{array}{l}\text { Random sequence genera- } \\
\text { tion (selection bias) }\end{array}$ & High risk & Uncontrolled trial \\
\hline $\begin{array}{l}\text { Allocation concealment } \\
\text { (selection bias) }\end{array}$ & High risk & Uncontrolled trial \\
\hline $\begin{array}{l}\text { Blinding of participants } \\
\text { and personnel (perfor- } \\
\text { mance bias) } \\
\text { All outcomes }\end{array}$ & Unclear risk & Information insufficient to permit judgement of 'low risk' or 'high risk' \\
\hline
\end{tabular}

Blinding of outcome as-

Unclear risk Information insufficient to permit judgement of 'low risk' or 'high risk' sessment (detection bias)

All outcomes 
Peethambaram 2009 (Continued)
Incomplete outcome data Unclear risk
Information insufficient to permit judgement of 'low risk' or 'high risk' (attrition bias)

All outcomes

\begin{tabular}{lll}
\hline $\begin{array}{l}\text { Selective reporting (re- } \\
\text { porting bias) }\end{array}$ & Unclear risk & Information insufficient to permit judgement of 'low risk' or 'high risk' \\
\hline Other bias & Unclear risk & Information insufficient to permit judgement of 'low risk' or 'high risk' \\
\hline
\end{tabular}

Pfisterer 2006

\begin{tabular}{ll}
\hline Methods & Uncontrolled phase I study \\
\hline Participants & $\begin{array}{l}36 \text { stage I-IV ovarian cancer patients within } 6 \text { weeks after completion of chemotherapy for recurrent } \\
\text { disease (disease status at study entry not described) }\end{array}$ \\
\hline Interventions & Subcutaneous monoclonal antibody (abagovomab - CA-125) \\
\hline Outcomes & Immune responses: humoral (Ab3, HAMA), cellular \\
& Adverse events \\
\hline
\end{tabular}

Notes

\section{Risk of bias}

\begin{tabular}{|c|c|c|}
\hline Bias & Authors' judgement & Support for judgement \\
\hline $\begin{array}{l}\text { Random sequence genera- } \\
\text { tion (selection bias) }\end{array}$ & High risk & Uncontrolled trial \\
\hline $\begin{array}{l}\text { Allocation concealment } \\
\text { (selection bias) }\end{array}$ & High risk & Uncontrolled trial \\
\hline $\begin{array}{l}\text { Blinding of participants } \\
\text { and personnel (perfor- } \\
\text { mance bias) } \\
\text { All outcomes }\end{array}$ & Unclear risk & Information insufficient to permit judgement of 'low risk' or 'high risk' \\
\hline $\begin{array}{l}\text { Blinding of outcome as- } \\
\text { sessment (detection bias) } \\
\text { All outcomes }\end{array}$ & Unclear risk & Information insufficient to permit judgement of 'low risk' or 'high risk' \\
\hline $\begin{array}{l}\text { Incomplete outcome data } \\
\text { (attrition bias) } \\
\text { All outcomes }\end{array}$ & Unclear risk & Information insufficient to permit judgement of 'low risk' or 'high risk' \\
\hline $\begin{array}{l}\text { Selective reporting (re- } \\
\text { porting bias) }\end{array}$ & Unclear risk & Information insufficient to permit judgement of 'low risk' or 'high risk' \\
\hline Other bias & Unclear risk & Information insufficient to permit judgement of 'low risk' or 'high risk' \\
\hline
\end{tabular}


Rahma 2012

\begin{tabular}{ll}
\hline Methods & Uncontrolled phase Il study \\
\hline Participants & 21 ovarian cancer patients without evidence of disease after prior therapy \\
\hline Interventions & Subcutaneous short peptide (p53) vs intravenous peptide-pulsed dendritic cells (p53) \\
& Adjuvant: Montanide ISA-51 and GM-CSF (only in cohort treated with peptide) \\
\hline Outcomes & Survival (progression-free survival, overall survival) \\
& Tumour responses \\
& Immune responses: cellular \\
Adverse events
\end{tabular}

Notes

\section{Risk of bias}

\begin{tabular}{|c|c|c|}
\hline Bias & Authors' judgement & Support for judgement \\
\hline $\begin{array}{l}\text { Random sequence genera- } \\
\text { tion (selection bias) }\end{array}$ & High risk & Uncontrolled trial \\
\hline $\begin{array}{l}\text { Allocation concealment } \\
\text { (selection bias) }\end{array}$ & High risk & Uncontrolled trial \\
\hline $\begin{array}{l}\text { Blinding of participants } \\
\text { and personnel (perfor- } \\
\text { mance bias) } \\
\text { All outcomes }\end{array}$ & Unclear risk & Information insufficient to permit judgement of 'low risk' or 'high risk' \\
\hline $\begin{array}{l}\text { Blinding of outcome as- } \\
\text { sessment (detection bias) } \\
\text { All outcomes }\end{array}$ & Unclear risk & Information insufficient to permit judgement of 'low risk' or 'high risk' \\
\hline $\begin{array}{l}\text { Incomplete outcome data } \\
\text { (attrition bias) } \\
\text { All outcomes }\end{array}$ & Unclear risk & Information insufficient to permit judgement of 'low risk' or 'high risk' \\
\hline $\begin{array}{l}\text { Selective reporting (re- } \\
\text { porting bias) }\end{array}$ & Unclear risk & Information insufficient to permit judgement of 'low risk' or 'high risk' \\
\hline Other bias & Unclear risk & Information insufficient to permit judgement of 'low risk' or 'high risk' \\
\hline
\end{tabular}

\begin{tabular}{ll}
\hline Reinartz 2004 & \\
\hline Methods & Uncontrolled multi-centre phase Ib/ll study \\
\hline Participants & 119 patients with ovarian cancer after at least primary treatment (disease status at entry not described) \\
\hline Interventions & Intramuscular monoclonal antibody (ACA125 - CA-125) \\
\hline Outcomes & Survival (time from first dose to death) \\
& Tumour responses \\
\hline
\end{tabular}


Reinartz 2004 (Continued)

Adverse events

Notes

\section{Risk of bias}

\begin{tabular}{|c|c|c|}
\hline Bias & Authors' judgement & Support for judgement \\
\hline $\begin{array}{l}\text { Random sequence genera- } \\
\text { tion (selection bias) }\end{array}$ & High risk & Uncontrolled trial \\
\hline $\begin{array}{l}\text { Allocation concealment } \\
\text { (selection bias) }\end{array}$ & High risk & Uncontrolled trial \\
\hline $\begin{array}{l}\text { Blinding of participants } \\
\text { and personnel (perfor- } \\
\text { mance bias) } \\
\text { All outcomes }\end{array}$ & Unclear risk & Information insufficient to permit judgement of 'low risk' or 'high risk' \\
\hline $\begin{array}{l}\text { Blinding of outcome as- } \\
\text { sessment (detection bias) } \\
\text { All outcomes }\end{array}$ & Unclear risk & Information insufficient to permit judgement of 'low risk' or 'high risk' \\
\hline $\begin{array}{l}\text { Incomplete outcome data } \\
\text { (attrition bias) } \\
\text { All outcomes }\end{array}$ & Unclear risk & Information insufficient to permit judgement of 'low risk' or 'high risk' \\
\hline $\begin{array}{l}\text { Selective reporting (re- } \\
\text { porting bias) }\end{array}$ & Unclear risk & Information insufficient to permit judgement of 'low risk' or 'high risk' \\
\hline Other bias & Unclear risk & Information insufficient to permit judgement of 'low risk' or 'high risk' \\
\hline
\end{tabular}

\section{Sabbatini 2000}

\begin{tabular}{ll}
\hline Methods & Uncontrolled phase I study \\
\hline Participants & $\begin{array}{l}25 \text { ovarian cancer patients with complete clinical response to chemotherapy after residual or recurrent } \\
\text { disease following primary therapy }\end{array}$ \\
\hline Interventions & Subcutaneous KLH conjugate (Lewis Y pentasaccharide - MUC1) \\
& Adjuvant: QS-21 \\
\hline Outcomes & Survival (time to progression) \\
& Immune responses: humoral \\
& Adverse events
\end{tabular}

\section{Notes}

\section{Risk of bias}

Bias Authors' judgement Support for judgement


Sabbatini 2000 (Continued)

\begin{tabular}{|c|c|c|}
\hline $\begin{array}{l}\text { Random sequence genera- } \\
\text { tion (selection bias) }\end{array}$ & High risk & Uncontrolled trial \\
\hline $\begin{array}{l}\text { Allocation concealment } \\
\text { (selection bias) }\end{array}$ & High risk & Uncontrolled trial \\
\hline $\begin{array}{l}\text { Blinding of participants } \\
\text { and personnel (perfor- } \\
\text { mance bias) } \\
\text { All outcomes }\end{array}$ & Unclear risk & Information insufficient to permit judgement of 'low risk' or 'high risk' \\
\hline
\end{tabular}

Blinding of outcome as-
sessment (detection bias) $\quad$ Unclear risk Information insufficient to permit judgement of 'low risk' or 'high risk'

All outcomes

Incomplete outcome data Unclear risk Information insufficient to permit judgement of 'low risk' or 'high risk'
(attrition bias)

All outcomes

\begin{tabular}{lll}
\hline $\begin{array}{l}\text { Selective reporting (re- } \\
\text { porting bias) }\end{array}$ & Unclear risk & Information insufficient to permit judgement of 'low risk' or 'high risk' \\
\hline Other bias & Unclear risk & Information insufficient to permit judgement of 'low risk' or 'high risk' \\
\hline
\end{tabular}

\section{Sabbatini 2006}

\begin{tabular}{ll}
\hline Methods & Randomised open-label multi-centre phase I study \\
\hline Participants & $\begin{array}{l}42 \text { stage II-IV ovarian cancer patients after chemotherapy for recurrence of disease with complete clini- } \\
\text { cal response or measurable disease }(<2 \mathrm{~cm})\end{array}$ \\
\hline Interventions & $\begin{array}{l}\text { Intramuscular (IM) or subcutaneous (SC) monoclonal antibody (abagovomab - CA-125): } 4 \text { cohorts (2× } \\
\text { IM; } 2 \times \text { SC; } 0.2 \mathrm{mg} \text { or } 2 \mathrm{mg})\end{array}$ \\
\hline Outcomes & Survival (time to progression) \\
& Tumour responses \\
Immune response: humoral (Ab3, HAMA), cellular \\
Adverse events
\end{tabular}

Notes

\section{Risk of bias}

\begin{tabular}{lll}
\hline Bias & Authors' judgement & Support for judgement \\
\hline $\begin{array}{l}\text { Random sequence genera- } \\
\text { tion (selection bias) }\end{array}$ & Low risk & Standard $2 \times 2$ factorial design \\
\hline $\begin{array}{l}\text { Allocation concealment } \\
\text { (selection bias) }\end{array}$ & Unclear risk & Information insufficient to permit judgement of 'low risk' or 'high risk' \\
\hline
\end{tabular}


Sabbatini 2006 (Continued)

Blinding of participants Low risk No blinding or incomplete blinding, but review authors judge that the outand personnel (perforcome is not likely to be influenced by lack of blinding mance bias)

All outcomes

\section{Blinding of outcome as-} sessment (detection bias)

All outcomes

\section{Incomplete outcome data Unclear risk} (attrition bias)

All outcomes
Reporting of attrition/exclusions insufficient to permit judgement of 'low risk' or 'high risk'

Selective reporting (re- Unclear risk Information insufficient to permit judgement of 'low risk' or 'high risk'
porting bias)

Other bias Low risk No other sources of bias detected

Sabbatini 2007

\begin{tabular}{ll}
\hline Methods & Uncontrolled phase I/II study \\
\hline Participants & $\begin{array}{l}11 \text { epithelial ovarian cancer patients with complete clinical remission after primary therapy or } \\
\text { chemotherapy for recurrent disease }\end{array}$ \\
\hline Interventions & Subcutaneous heptavalent KLH conjugate (GM2, Globo-H, Lewis Y, Tn-MUC1, Tn(c), STN(c), TF(c)) \\
\hline Outcomes & Survival (time to treatment failure) \\
Immune responses: humoral
\end{tabular}

Notes

\section{Risk of bias}

\begin{tabular}{|c|c|c|}
\hline Bias & Authors' judgement & Support for judgement \\
\hline $\begin{array}{l}\text { Random sequence genera- } \\
\text { tion (selection bias) }\end{array}$ & High risk & Uncontrolled trial \\
\hline $\begin{array}{l}\text { Allocation concealment } \\
\text { (selection bias) }\end{array}$ & High risk & Uncontrolled trial \\
\hline $\begin{array}{l}\text { Blinding of participants } \\
\text { and personnel (perfor- } \\
\text { mance bias) } \\
\text { All outcomes }\end{array}$ & Unclear risk & Information insufficient to permit judgement of 'low risk' or 'high risk' \\
\hline $\begin{array}{l}\text { Blinding of outcome as- } \\
\text { sessment (detection bias) } \\
\text { All outcomes }\end{array}$ & Unclear risk & Information insufficient to permit judgement of 'low risk' or 'high risk' \\
\hline $\begin{array}{l}\text { Incomplete outcome data } \\
\text { (attrition bias) } \\
\text { All outcomes }\end{array}$ & Unclear risk & Information insufficient to permit judgement of 'low risk' or 'high risk' \\
\hline
\end{tabular}


Sabbatini 2007 (Continued)

Selective reporting (re- Unclear risk Information insufficient to permit judgement of 'low risk' or 'high risk' porting bias)

Other bias Unclear risk Information insufficient to permit judgement of 'low risk' or 'high risk'

Sabbatini 2012

\begin{tabular}{ll}
\hline Methods & Uncontrolled phase I study \\
\hline Participants & 28 ovarian cancer patients in second or third remission \\
\hline Interventions & Subcutaneous overlapping long peptides (NY-ESO-1) \\
& Adjuvant: cohort 1 - no $(\mathrm{n}=4)$; cohort 2: Montanide ISA-51 ( $=$ 13); cohort 3: poly-ICLC in Montanide \\
& ISA-51 $(\mathrm{n}=11)$ \\
\hline Outcomes & Survival (time to progression) \\
& Tumour responses \\
Immune responses: cellular and humoral \\
Adverse events
\end{tabular}

Notes

\section{Risk of bias}

Bias Authors' judgement Support for judgement

Random sequence genera- High risk Uncontrolled trial

tion (selection bias)

\begin{tabular}{|c|c|c|}
\hline $\begin{array}{l}\text { Allocation concealment } \\
\text { (selection bias) }\end{array}$ & High risk & Uncontrolled trial \\
\hline $\begin{array}{l}\text { Blinding of participants } \\
\text { and personnel (perfor- } \\
\text { mance bias) } \\
\text { All outcomes }\end{array}$ & Unclear risk & Information insufficient to permit judgement of 'low risk' or 'high risk' \\
\hline $\begin{array}{l}\text { Blinding of outcome as- } \\
\text { sessment (detection bias) } \\
\text { All outcomes }\end{array}$ & Unclear risk & Information insufficient to permit judgement of 'low risk' or 'high risk' \\
\hline $\begin{array}{l}\text { Incomplete outcome data } \\
\text { (attrition bias) } \\
\text { All outcomes }\end{array}$ & Unclear risk & Information insufficient to permit judgement of 'low risk' or 'high risk' \\
\hline $\begin{array}{l}\text { Selective reporting (re- } \\
\text { porting bias) }\end{array}$ & Unclear risk & Information insufficient to permit judgement of 'low risk' or 'high risk' \\
\hline Other bias & Unclear risk & Information insufficient to permit judgement of 'low risk' or 'high risk' \\
\hline
\end{tabular}


Sabbatini 2013

\begin{tabular}{ll}
\hline Methods & Randomised placebo-controlled trial \\
\hline Participants & 888 ovarian cancer patients in complete clinical remission after primary therapy \\
\hline Interventions & Subcutaneous monoclonal antibody (abagovomab - CA-125) \\
\hline Outcomes & Survival (recurrence-free survival, overall survival) \\
Immune responses: humoral (Ab3, HAMA), cellular (to be reported in separate paper) \\
Adverse events
\end{tabular}

Notes

\section{Risk of bias}

\begin{tabular}{|c|c|c|}
\hline Bias & Authors' judgement & Support for judgement \\
\hline $\begin{array}{l}\text { Random sequence genera- } \\
\text { tion (selection bias) }\end{array}$ & Low risk & Centralised randomisation \\
\hline $\begin{array}{l}\text { Allocation concealment } \\
\text { (selection bias) }\end{array}$ & Low risk & Centralised randomisation \\
\hline $\begin{array}{l}\text { Blinding of participants } \\
\text { and personnel (perfor- } \\
\text { mance bias) } \\
\text { All outcomes }\end{array}$ & Low risk & $\begin{array}{l}\text { Blinding of participants and key study personnel ensured; unlikely that the } \\
\text { blinding could have been broken }\end{array}$ \\
\hline $\begin{array}{l}\text { Blinding of outcome as- } \\
\text { sessment (detection bias) } \\
\text { All outcomes }\end{array}$ & Low risk & $\begin{array}{l}\text { Blinding of outcome assessment ensured; unlikely that the blinding could } \\
\text { have been broken }\end{array}$ \\
\hline $\begin{array}{l}\text { Incomplete outcome data } \\
\text { (attrition bias) } \\
\text { All outcomes }\end{array}$ & Low risk & $\begin{array}{l}\text { Missing outcome data balanced in numbers across intervention groups, with } \\
\text { similar reasons for missing data across groups }\end{array}$ \\
\hline $\begin{array}{l}\text { Selective reporting (re- } \\
\text { porting bias) }\end{array}$ & Unclear risk & Information insufficient to permit judgement of 'low risk' or 'high risk' \\
\hline Other bias & Low risk & No other forms of bias detected \\
\hline
\end{tabular}

Sabbatini 2017

\begin{tabular}{ll}
\hline Methods & Randomised trial \\
\hline Participants & 171 participants with epithelial ovarian cancer in second or third clinical remission \\
\hline Interventions & OPT-821 $(\mathrm{n}=86)+$ polyvalent vaccine conjugate (Globo-H-GM2, MUC1-TN,TF) vs OPT-821 alone $(\mathrm{n}=85)$ \\
\hline Outcomes & \\
\hline Notes
\end{tabular}

\section{Risk of bias}


Sabbatini 2017 (Continued)

\begin{tabular}{|c|c|c|}
\hline Bias & Authors' judgement & Support for judgement \\
\hline $\begin{array}{l}\text { Random sequence genera- } \\
\text { tion (selection bias) }\end{array}$ & Low risk & Randomised trial \\
\hline $\begin{array}{l}\text { Allocation concealment } \\
\text { (selection bias) }\end{array}$ & Low risk & Randomised allocation \\
\hline $\begin{array}{l}\text { Blinding of participants } \\
\text { and personnel (perfor- } \\
\text { mance bias) } \\
\text { All outcomes }\end{array}$ & Low risk & Double-blinding of participant and investigator \\
\hline $\begin{array}{l}\text { Blinding of outcome as- } \\
\text { sessment (detection bias) } \\
\text { All outcomes }\end{array}$ & Low risk & Double-blinding of participant and investigator \\
\hline $\begin{array}{l}\text { Incomplete outcome data } \\
\text { (attrition bias) } \\
\text { All outcomes }\end{array}$ & Low risk & All participants analysed for primary endpoint \\
\hline $\begin{array}{l}\text { Selective reporting (re- } \\
\text { porting bias) }\end{array}$ & Unclear risk & Information insufficient to permit judgement of 'low risk' or 'high risk' \\
\hline Other bias & Low risk & No other forms of bias detected \\
\hline
\end{tabular}

Sandmaier 1999

\begin{tabular}{ll}
\hline Methods & Uncontrolled phase Il study \\
\hline Participants & $\begin{array}{l}40 \text { breast or ovarian cancer }(n=7) \text { patients who underwent high-dose chemotherapy and autologous or } \\
\text { syngeneic stem cell rescue (disease status at study entry unknown) }\end{array}$ \\
\hline Interventions & Subcutaneous KLH conjugate (Sialyl-Tn) \\
& Adjuvant: Detox B \\
\hline Outcomes & Immune responses: humoral, cellular \\
\hline Notes &
\end{tabular}

\section{Risk of bias}

\begin{tabular}{lll}
\hline Bias & Authors' judgement & Support for judgement \\
\hline $\begin{array}{l}\text { Random sequence genera- } \\
\text { tion (selection bias) }\end{array}$ & High risk & Uncontrolled trial \\
\hline $\begin{array}{l}\text { Allocation concealment } \\
\text { (selection bias) }\end{array}$ & High risk & Uncontrolled trial \\
\hline $\begin{array}{l}\text { Blinding of participants } \\
\text { and personnel (perfor- } \\
\text { mance bias) }\end{array}$ & Unclear risk & Information insufficient to permit judgement of 'low risk' or 'high risk' \\
All outcomes & \\
\hline
\end{tabular}


Sandmaier 1999 (Continued)

Blinding of outcome as- Unclear risk Information insufficient to permit judgement of 'low risk' or 'high risk' sessment (detection bias)

All outcomes

\begin{tabular}{lll}
\hline $\begin{array}{l}\text { Incomplete outcome data } \\
\text { (attrition bias) } \\
\text { All outcomes }\end{array}$ & Unclear risk & Information insufficient to permit judgement of 'low risk' or 'high risk' \\
\hline $\begin{array}{l}\text { Selective reporting (re- } \\
\text { porting bias) }\end{array}$ & Unclear risk & Information insufficient to permit judgement of 'low risk' or 'high risk' \\
\hline Other bias & Unclear risk & Information insufficient to permit judgement of 'low risk' or 'high risk' \\
\hline
\end{tabular}

\section{Schultes 1998}

\begin{tabular}{ll}
\hline Methods & Retrospective uncontrolled study \\
\hline Participants & 75 stage I-IV ovarian cancer patients (disease status at study entry not described) \\
\hline Interventions & Intravenous monoclonal antibody (oregovomab - CA-125) \\
\hline Outcomes & Survival (overall survival) \\
& Immune responses: humoral (Ab2, Ab3, HAMA) \\
\hline Notes & \\
\hline
\end{tabular}

\section{Risk of bias}

\begin{tabular}{|c|c|c|}
\hline Bias & Authors' judgement & Support for judgement \\
\hline $\begin{array}{l}\text { Random sequence genera- } \\
\text { tion (selection bias) }\end{array}$ & High risk & Uncontrolled trial \\
\hline $\begin{array}{l}\text { Allocation concealment } \\
\text { (selection bias) }\end{array}$ & High risk & Uncontrolled trial \\
\hline $\begin{array}{l}\text { Blinding of participants } \\
\text { and personnel (perfor- } \\
\text { mance bias) } \\
\text { All outcomes }\end{array}$ & Unclear risk & Information insufficient to permit judgement of 'low risk' or 'high risk' \\
\hline $\begin{array}{l}\text { Blinding of outcome as- } \\
\text { sessment (detection bias) } \\
\text { All outcomes }\end{array}$ & Unclear risk & Information insufficient to permit judgement of 'low risk' or 'high risk' \\
\hline $\begin{array}{l}\text { Incomplete outcome data } \\
\text { (attrition bias) } \\
\text { All outcomes }\end{array}$ & Unclear risk & Information insufficient to permit judgement of 'low risk' or 'high risk' \\
\hline $\begin{array}{l}\text { Selective reporting (re- } \\
\text { porting bias) }\end{array}$ & Unclear risk & Information insufficient to permit judgement of 'low risk' or 'high risk' \\
\hline Other bias & Unclear risk & Information insufficient to permit judgement of 'low risk' or 'high risk' \\
\hline
\end{tabular}


Ströhlein 2009

\begin{tabular}{ll}
\hline Methods & Uncontrolled phase I study \\
\hline Participants & 9 patients with progressive peritoneal carcinomatosis (ovarian cancer $\mathrm{n}=2)$ \\
\hline Interventions & Intraperitoneal trifunctional antibody targeting EpCAM $(\mathrm{n}=1)$ or Her-2/Neu $(\mathrm{n}=1)$ \\
\hline Outcomes & Survival: not reported separately for ovarian cancer patients \\
& Tumour responses \\
& Immune responses: cellular, humoral (HAMA) \\
& Adverse events
\end{tabular}

Notes

\section{Risk of bias}

\section{Bias Authors' judgement Support for judgement}

Random sequence genera- High risk Uncontrolled trial

tion (selection bias)

\begin{tabular}{|c|c|c|}
\hline $\begin{array}{l}\text { Allocation concealment } \\
\text { (selection bias) }\end{array}$ & High risk & Uncontrolled trial \\
\hline $\begin{array}{l}\text { Blinding of participants } \\
\text { and personnel (perfor- } \\
\text { mance bias) } \\
\text { All outcomes }\end{array}$ & Unclear risk & Information insufficient to permit judgement of 'low risk' or 'high risk' \\
\hline $\begin{array}{l}\text { Blinding of outcome as- } \\
\text { sessment (detection bias) } \\
\text { All outcomes }\end{array}$ & Unclear risk & Information insufficient to permit judgement of 'low risk' or 'high risk' \\
\hline $\begin{array}{l}\text { Incomplete outcome data } \\
\text { (attrition bias) } \\
\text { All outcomes }\end{array}$ & Unclear risk & Information insufficient to permit judgement of 'low risk' or 'high risk' \\
\hline $\begin{array}{l}\text { Selective reporting (re- } \\
\text { porting bias) }\end{array}$ & Unclear risk & Information insufficient to permit judgement of 'low risk' or 'high risk' \\
\hline Other bias & Unclear risk & Information insufficient to permit judgement of 'low risk' or 'high risk' \\
\hline
\end{tabular}

Suzuki 2016

\begin{tabular}{ll}
\hline Methods & Uncontrolled phase II \\
\hline Participants & 32 women with clear cell ovarian carcinoma \\
\hline Interventions & Antigen glypican-3 (GPC3) vaccine \\
\hline Outcomes & Immune response
\end{tabular}


Suzuki 2016 (Continued)

Clinical response

Safety

\section{Notes}

\section{Risk of bias}

\begin{tabular}{|c|c|c|}
\hline Bias & Authors' judgement & Support for judgement \\
\hline $\begin{array}{l}\text { Random sequence genera- } \\
\text { tion (selection bias) }\end{array}$ & High risk & Uncontrolled trial \\
\hline $\begin{array}{l}\text { Allocation concealment } \\
\text { (selection bias) }\end{array}$ & High risk & Uncontrolled trial \\
\hline $\begin{array}{l}\text { Blinding of participants } \\
\text { and personnel (perfor- } \\
\text { mance bias) } \\
\text { All outcomes }\end{array}$ & Unclear risk & Information insufficient to permit judgement of 'low risk' or 'high risk' \\
\hline $\begin{array}{l}\text { Blinding of outcome as- } \\
\text { sessment (detection bias) } \\
\text { All outcomes }\end{array}$ & Unclear risk & Information insufficient to permit judgement of 'low risk' or 'high risk' \\
\hline $\begin{array}{l}\text { Incomplete outcome data } \\
\text { (attrition bias) } \\
\text { All outcomes }\end{array}$ & Unclear risk & Information insufficient to permit judgement of 'low risk' or 'high risk' \\
\hline $\begin{array}{l}\text { Selective reporting (re- } \\
\text { porting bias) }\end{array}$ & Unclear risk & Information insufficient to permit judgement of 'low risk' or 'high risk' \\
\hline Other bias & Unclear risk & Information insufficient to permit judgement of 'low risk' or 'high risk' \\
\hline
\end{tabular}

\section{Takeoka 2017}

\begin{tabular}{ll}
\hline Methods & Uncontrolled phase I \\
\hline Participants & 15 participants with advanced cancer expressing NY-ESO-1 (N = 2 ovarian cancer cohort 3) \\
\hline Interventions & Cohort 1: NY-ESO-1 protein \\
& Cohort 2a: NY-ESO-1 protein + OK-432 \\
& Cohort 2b: NY-ESO-1 protein + poly-ICLC \\
& Cohort 3: NY-ESO-1 protein + OK-432 + poly-ICLC with Montanide ISA-51 \\
\hline Outcomes & Safety \\
Immune response \\
Clinical response
\end{tabular}

\section{Notes}

\section{Risk of bias}

Antigen-specific active immunotherapy for ovarian cancer (Review) 
Takeoka 2017 (Continued)

\begin{tabular}{lll} 
Bias & Authors' judgement & Support for judgement \\
\hline $\begin{array}{l}\text { Random sequence genera- } \\
\text { tion (selection bias) }\end{array}$ & High risk & Uncontrolled trial \\
\hline $\begin{array}{l}\text { Allocation concealment } \\
\text { (selection bias) }\end{array}$ & High risk & Uncontrolled trial \\
\hline
\end{tabular}

Blinding of participants $\quad$ High risk
and personnel (perfor-
mance bias)

\begin{tabular}{lll}
\hline $\begin{array}{l}\text { Blinding of outcome as- } \\
\text { sessment (detection bias) } \\
\text { All outcomes }\end{array}$ & High risk & Open-label study \\
\hline $\begin{array}{l}\text { Incomplete outcome data } \\
\begin{array}{l}\text { (attrition bias) } \\
\text { All outcomes }\end{array}\end{array}$ & Low risk & All OC patients analysed \\
\hline $\begin{array}{l}\text { Selective reporting (re- } \\
\text { porting bias) }\end{array}$ & Unclear risk & Information insufficient to permit judgement of 'low risk' or 'high risk' \\
\hline \begin{tabular}{l} 
Other bias \\
\hline
\end{tabular} & Unclear risk & Information insufficient to permit judgement of 'low risk' or 'high risk' \\
\hline
\end{tabular}

Takeuchi 2013

\begin{tabular}{ll}
\hline Methods & Uncontrolled phase I/II study \\
\hline Participants & 38 ovarian cancer patients with advanced/recurrent disease \\
\hline Interventions & Subcutaneous peptide cocktail (HLA-A24 - $\mathrm{n}=23$ : FOXM1, MELK, HJURP, VEGFR1, VEGFR2; HLA-A02 - $\mathrm{n}=$ \\
& 13: HIG2, VEGFR1, VEGFR2) \\
& Adjuvant: Montanide ISA-51 \\
\hline
\end{tabular}

\begin{tabular}{ll}
\hline Outcomes & Survival \\
& Tumour responses \\
& Immune responses (not adequately reported) \\
& Adverse events (not adequately reported) \\
\hline Notes & Meeting abstract \\
\hline
\end{tabular}

\section{Risk of bias}

\begin{tabular}{lll}
\hline Bias & Authors' judgement & Support for judgement \\
\hline $\begin{array}{l}\text { Random sequence genera- } \\
\text { tion (selection bias) }\end{array}$ & High risk & Uncontrolled trial \\
\hline $\begin{array}{l}\text { Allocation concealment } \\
\text { (selection bias) }\end{array}$ & High risk & Uncontrolled trial \\
\hline
\end{tabular}


Takeuchi 2013 (Continued)

Blinding of participants Unclear risk Information insufficient to permit judgement of 'low risk' or 'high risk' and personnel (performance bias)

All outcomes

\begin{tabular}{ll}
\hline Blinding of outcome as- \\
sessment (detection bias)
\end{tabular}$\quad$ Unclear risk Information insufficient to permit judgement of 'low risk' or 'high risk'

All outcomes

Incomplete outcome data Unclear risk Information insufficient to permit judgement of 'low risk' or 'high risk'
(attrition bias)

Selective reporting (re- Unclear risk Information insufficient to permit judgement of 'low risk' or 'high risk'
porting bias)

Other bias Unclear risk Information insufficient to permit judgement of 'low risk' or 'high risk'

Tsuda 2004

\begin{tabular}{ll}
\hline Methods & Uncontrolled phase I/II study \\
\hline Participants & 14 patients with gynaecological cancer after primary therapy (ovarian cancer $n=5 ; N E D ~ n=2)$ \\
\hline Interventions & Subcutaneous individualised short peptide cocktail \\
& Adjuvant: Montanide ISA-51 \\
\hline
\end{tabular}

\begin{tabular}{ll}
\hline Outcomes & Tumour responses \\
Immune responses: humoral, cellular \\
Adverse events: not separately described for ovarian cancer patients
\end{tabular}

Notes

Risk of bias

\begin{tabular}{|c|c|c|}
\hline Bias & Authors' judgement & Support for judgement \\
\hline $\begin{array}{l}\text { Random sequence genera- } \\
\text { tion (selection bias) }\end{array}$ & High risk & Uncontrolled trial \\
\hline $\begin{array}{l}\text { Allocation concealment } \\
\text { (selection bias) }\end{array}$ & High risk & Uncontrolled trial \\
\hline $\begin{array}{l}\text { Blinding of participants } \\
\text { and personnel (perfor- } \\
\text { mance bias) } \\
\text { All outcomes }\end{array}$ & Unclear risk & Information insufficient to permit judgement of 'low risk' or 'high risk' \\
\hline $\begin{array}{l}\text { Blinding of outcome as- } \\
\text { sessment (detection bias) } \\
\text { All outcomes }\end{array}$ & Unclear risk & Information insufficient to permit judgement of 'low risk' or 'high risk' \\
\hline
\end{tabular}


Tsuda 2004 (Continued)

Incomplete outcome data Unclear risk Information insufficient to permit judgement of 'low risk' or 'high risk'
(attrition bias)
(attrition bias)

All outcomes

\begin{tabular}{lll}
\hline $\begin{array}{l}\text { Selective reporting (re- } \\
\text { porting bias) }\end{array}$ & Unclear risk & Information insufficient to permit judgement of 'low risk' or 'high risk' \\
\hline Other bias & Unclear risk & Information insufficient to permit judgement of 'low risk' or 'high risk' \\
\hline
\end{tabular}

van Zanten-Przybysz 2002

\begin{tabular}{ll}
\hline Methods & Uncontrolled phase I/II study \\
\hline Participants & $\begin{array}{l}5 \text { patients with residual or recurrent ovarian cancer after primary debulking surgery and at least } 1 \\
\text { course of chemotherapy }\end{array}$ \\
\hline Interventions & Intravenous monoclonal antibody (c-MOv18 - membrane folate receptor) \\
\hline Outcomes & Survival: median time from first dose to death: 22.0 months \\
& Tumour responses: $3 \times$ PD, $2 \times$ SD \\
Immune responses: cellular \\
Adverse events: max grade I events
\end{tabular}

\section{Notes}

\section{Risk of bias}

\begin{tabular}{|c|c|c|}
\hline Bias & Authors' judgement & Support for judgement \\
\hline $\begin{array}{l}\text { Random sequence genera- } \\
\text { tion (selection bias) }\end{array}$ & High risk & Uncontrolled trial \\
\hline $\begin{array}{l}\text { Allocation concealment } \\
\text { (selection bias) }\end{array}$ & High risk & Uncontrolled trial \\
\hline $\begin{array}{l}\text { Blinding of participants } \\
\text { and personnel (perfor- } \\
\text { mance bias) } \\
\text { All outcomes }\end{array}$ & Unclear risk & Information insufficient to permit judgement of 'low risk' or 'high risk' \\
\hline $\begin{array}{l}\text { Blinding of outcome as- } \\
\text { sessment (detection bias) } \\
\text { All outcomes }\end{array}$ & Unclear risk & Information insufficient to permit judgement of 'low risk' or 'high risk' \\
\hline $\begin{array}{l}\text { Incomplete outcome data } \\
\text { (attrition bias) } \\
\text { All outcomes }\end{array}$ & Unclear risk & Information insufficient to permit judgement of 'low risk' or 'high risk' \\
\hline $\begin{array}{l}\text { Selective reporting (re- } \\
\text { porting bias) }\end{array}$ & Unclear risk & Information insufficient to permit judgement of 'low risk' or 'high risk' \\
\hline Other bias & Unclear risk & Information insufficient to permit judgement of 'low risk' or 'high risk' \\
\hline
\end{tabular}


Vermeij 2012

\begin{tabular}{ll}
\hline Methods & Uncontrolled phase II study \\
\hline Participants & $\begin{array}{l}12 \text { women with epithelial ovarian cancer with (biochemical) recurrence not (yet) eligible for renewed } \\
\text { chemotherapy }\end{array}$ \\
\hline Interventions & Subcutaneous synthetic long peptides (p53) \\
Adjuvant: Montanide ISA51 \\
Immunomodulation: cyclophosphamide 2 days before each vaccination \\
\hline Outcomes & Tumour responses \\
Immunological responses: cellular \\
Adverse events
\end{tabular}

Notes

\section{Risk of bias}

\begin{tabular}{|c|c|c|}
\hline Bias & Authors' judgement & Support for judgement \\
\hline $\begin{array}{l}\text { Random sequence genera- } \\
\text { tion (selection bias) }\end{array}$ & High risk & Uncontrolled trial \\
\hline $\begin{array}{l}\text { Allocation concealment } \\
\text { (selection bias) }\end{array}$ & High risk & Uncontrolled trial \\
\hline $\begin{array}{l}\text { Blinding of participants } \\
\text { and personnel (perfor- } \\
\text { mance bias) } \\
\text { All outcomes }\end{array}$ & Unclear risk & Information insufficient to permit judgement of 'low risk' or 'high risk' \\
\hline $\begin{array}{l}\text { Blinding of outcome as- } \\
\text { sessment (detection bias) } \\
\text { All outcomes }\end{array}$ & Unclear risk & Information insufficient to permit judgement of 'low risk' or 'high risk' \\
\hline $\begin{array}{l}\text { Incomplete outcome data } \\
\text { (attrition bias) } \\
\text { All outcomes }\end{array}$ & Unclear risk & Information insufficient to permit judgement of 'low risk' or 'high risk' \\
\hline $\begin{array}{l}\text { Selective reporting (re- } \\
\text { porting bias) }\end{array}$ & Unclear risk & Information insufficient to permit judgement of 'low risk' or 'high risk' \\
\hline Other bias & Unclear risk & Information insufficient to permit judgement of 'low risk' or 'high risk' \\
\hline
\end{tabular}

\section{Wagner 1993}

\begin{tabular}{ll}
\hline Methods & Retrospective uncontrolled study \\
\hline Participants & $\begin{array}{l}58 \text { patients with advanced-stage ovarian cancer after primary treatment with high preoperative CA-125 } \\
\text { levels (disease status at study entry not described) }\end{array}$ \\
\hline
\end{tabular}


Wagner 1993 (Continued)

Interventions Intravenous monoclonal antibody fragments $\left(\mathrm{F}(\mathrm{Ab})_{2}\right.$-fragments of MAb OC125 - CA-125)

\begin{tabular}{ll}
\hline Outcomes & Survival \\
Tumour responses \\
Immune responses: humoral (Ab2), cellular
\end{tabular}

Notes

Risk of bias

\begin{tabular}{|c|c|c|}
\hline Bias & Authors' judgement & Support for judgement \\
\hline $\begin{array}{l}\text { Random sequence genera- } \\
\text { tion (selection bias) }\end{array}$ & High risk & Uncontrolled trial \\
\hline $\begin{array}{l}\text { Allocation concealment } \\
\text { (selection bias) }\end{array}$ & High risk & Uncontrolled trial \\
\hline $\begin{array}{l}\text { Blinding of participants } \\
\text { and personnel (perfor- } \\
\text { mance bias) } \\
\text { All outcomes }\end{array}$ & Unclear risk & Information insufficient to permit judgement of 'low risk' or 'high risk' \\
\hline $\begin{array}{l}\text { Blinding of outcome as- } \\
\text { sessment (detection bias) } \\
\text { All outcomes }\end{array}$ & Unclear risk & Information insufficient to permit judgement of 'low risk' or 'high risk' \\
\hline $\begin{array}{l}\text { Incomplete outcome data } \\
\text { (attrition bias) } \\
\text { All outcomes }\end{array}$ & Unclear risk & Information insufficient to permit judgement of 'low risk' or 'high risk' \\
\hline $\begin{array}{l}\text { Selective reporting (re- } \\
\text { porting bias) }\end{array}$ & Unclear risk & Information insufficient to permit judgement of 'low risk' or 'high risk' \\
\hline Other bias & Unclear risk & Information insufficient to permit judgement of 'low risk' or 'high risk' \\
\hline
\end{tabular}

Ab2: anti-idiotype antibody.

Ab3: anti-anti-idiotype antibody.

CA-125: cancer antigen-125.

CEA: carcinoembryonic antigen.

EpCAM: epithelial cell adhesion molecule.

ErbB2: human Epidermal growth factor Receptor 2.

FBP: folate binding protein.

GM-CSF: granulocyte-macrophage colony-stimulating factor.

GPC3: antigen glypican-3.

HAMA: human-anti-mouse antibody.

HLA: human leucocyte antigen.

hTERT: telomerase reverse transcriptase.

$\mathrm{KLH}$ : keyhole limpet haemocyanin.

MAb: monoclonal antibody.

MAGE-A1: melanoma-associated antigen A1.

MUC1: Mucin-1.

NED: no evidence of disease.

OC: ovarian carcinoma.

OWD: 1-week delayed

PADRE: DR-restricted Th helper epitope. 
poly-ICLC: polyinosinic-polycytidylic acid complexed with poly-L-lysine and carboxymethylcellulose.

SIM: simultaneous infusion.

SLP: synthetic long peptide.

Characteristics of excluded studies [ordered by study ID]

\begin{tabular}{|c|c|}
\hline Study & Reason for exclusion \\
\hline Anderson 2000 & Only 1 woman with epithelial ovarian cancer; no ASAI \\
\hline Baek 2015 & No ASAI \\
\hline Bapsy 2014 & No ASAI \\
\hline Bender 2007 & Only 1 woman with epithelial ovarian cancer \\
\hline Bernal 2012 & Only 1 woman with epithelial ovarian cancer; no ASAI \\
\hline Carbone 2005 & Only 1 woman with epithelial ovarian cancer \\
\hline Chiang 2013 & No ASAI \\
\hline Coosemans 2013 & Only 1 woman with epithelial ovarian cancer \\
\hline Dhodapkar 2014 & Impossible to distinguish between other and women with ovarian cancer \\
\hline Disis 1999 & Impossible to distinguish between other and women with ovarian cancer \\
\hline Disis 2000 & Impossible to distinguish between other and women with ovarian cancer \\
\hline Disis 2002 & Impossible to distinguish between other and women with ovarian cancer \\
\hline Disis 2002a & Only 1 woman with epithelial ovarian cancer \\
\hline Disis 2004 & Impossible to distinguish between other and women with ovarian cancer \\
\hline Disis 2004a & Only 1 woman with epithelial ovarian cancer \\
\hline Galanis 2013 & No ASAI \\
\hline Haakenstad 2012 & Impossible to distinguish between other and women with ovarian cancer \\
\hline Hasumi 2011 & No ASAI \\
\hline Hernando 2002 & Autologous tumour lysate vaccine \\
\hline Hernando 2007 & Only 1 woman with epithelial ovarian cancer \\
\hline Holmberg 2000 & Impossible to distinguish between women with breast cancer and women with ovarian cancer \\
\hline Hui 1997 & No ASAI \\
\hline Jackson 2017 & Impossible to distinguish between other and women with ovarian cancer \\
\hline Jager 2006 & Only 1 woman with epithelial ovarian cancer \\
\hline Kandalaft 2010 & Autologous tumour lysate vaccine \\
\hline
\end{tabular}




\begin{tabular}{|c|c|}
\hline Study & Reason for exclusion \\
\hline Karbach 2010 & Only 1 woman with epithelial ovarian cancer \\
\hline Kato 2010 & Impossible to distinguish between other and women with ovarian cancer \\
\hline Khranovska 2011 & Autologous tumour lysate vaccine \\
\hline Knutson 2001 & Only 1 woman with epithelial ovarian cancer \\
\hline Knutson 2002 & Women with epithelial ovarian cancer withdrew before evaluation of immune responses. \\
\hline Letsch 2008 & Impossible to distinguish between other and women with ovarian cancer \\
\hline Loveland 2006 & Only 1 woman with epithelial ovarian cancer \\
\hline Manjunath 2012 & Only 1 woman with epithelial ovarian cancer \\
\hline Marshall 2005 & Only 1 woman with ovarian cancer \\
\hline Matsuzaki 2014 & Additional results to Odunsi 2007; irrelevant for review \\
\hline Miotti 1999 & Autologous T-cell vaccine \\
\hline Morera 2017 & Only 1 woman with epithelial ovarian cancer \\
\hline Morse 1999 & Impossible to distinguish between other and women with ovarian cancer \\
\hline Morse 2003 & Uncertain if and how many women with ovarian cancer were included \\
\hline Morse 2011a & $\begin{array}{l}\text { Impossible to distinguish between other and women with ovarian cancer; unclear number of } \\
\text { women with ovarian cancer }\end{array}$ \\
\hline Murray 2002 & Only 1 woman with epithelial ovarian cancer \\
\hline Oh 2016 & No ASAI \\
\hline Parkhurst 2004 & No women with epithelial ovarian cancer \\
\hline Reddish 1996 & Impossible to distinguish between other and women with ovarian cancer \\
\hline Salazar 2006 & Impossible to distinguish between other and women with ovarian cancer \\
\hline Schiffman 2002 & No immunisations carried out \\
\hline Tsuji 2013 & Additional results to Sabbatini 2013; irrelevant for review \\
\hline Yacyshyn 1995 & Additional results to MacLean 1992; irrelevant for review \\
\hline Zaks 1998 & Impossible to distinguish between other and women with ovarian cancer \\
\hline
\end{tabular}

ASAI: antigen-specific active immunotherapy.

Characteristics of ongoing studies [ordered by study ID] 
NCT00003002

\begin{tabular}{ll}
\hline Trial name or title & $\begin{array}{l}\text { Her-2/Neu vaccine plus GM-CSF in treating participants with stage III or stage IV breast, ovarian, or } \\
\text { non-small cell lung cancer }\end{array}$ \\
\hline Methods & Uncontrolled phase I \\
\hline Participants & Participants with stage III or IV Her-2/Neu-expressing breast, ovarian, or non-small cell lung cancer \\
\hline Interventions & Intradermal vaccinations of Her-2/Neu-derived peptides with sargramostim (GM-CSF) \\
\hline Outcomes & Immune responses \\
\hline Starting date & Adverse events \\
\hline Contact information & April 1996 \\
\hline Notes & Completed January 2004; no publication available \\
\hline
\end{tabular}

\section{NCT00004604}

\begin{tabular}{ll}
\hline Trial name or title & Biological therapy in treating patients with metastatic cancer \\
\hline Methods & Uncontrolled phase I \\
\hline Participants & $\begin{array}{l}24 \text { participants with histologically confirmed metastatic adenocarcinoma expressing carcinoem- } \\
\text { bryonic antigen (CEA) who has failed conventional therapy }\end{array}$ \\
\hline Interventions & Intravenous CEA RNA-pulsed autologous dendritic cells \\
\hline Outcomes & Adverse events \\
& Immune responses \\
Clinical and biochemical responses \\
\hline Contact information & February 1998 \\
\hline Notes & Completed July 2002; no publication available \\
\hline
\end{tabular}

\begin{tabular}{ll}
\hline NCT00006041 & Vaccine therapy in treating patients with ovarian, fallopian tube, or peritoneal cancer \\
\hline Methods & Uncontrolled phase I \\
\hline Participants & $\begin{array}{l}18 \text { patients with histologically confirmed ovarian, fallopian tube, or peritoneal epithelial cancer } \\
\text { (any stage at diagnosis); refractory or recurrent after cytoreductive surgery and at least } 1 \text { prior regi- } \\
\text { men of platinum-based chemotherapy }\end{array}$ \\
\hline Interventions & Glycosylated MUC1-KLH vaccine plus QS21 \\
\hline
\end{tabular}


NCT00006041 (Continued)

$\begin{array}{ll}\text { Outcomes } & \text { Adverse events } \\ \text { Immune responses }\end{array}$

Starting date $\quad$ February 2000

Contact information

Notes Completed February 2002; no publication available

\section{NCT00381173} $\begin{array}{ll}\text { Trial name or title } & \begin{array}{l}\text { A phase I open-label study of the safety and feasibility of ZYC300 administration with cyclophos- } \\ \text { phamide pre-dosing }\end{array}\end{array}$

\begin{tabular}{ll}
\hline Methods & Phase I \\
\hline Participants & 22 advanced-stage malignancies with evidence of disease and no therapeutic options \\
\hline Interventions & $\begin{array}{l}\text { IM ZYC300 (a plasmid DNA formulated within biodegradable microencapsulated particles) with IV } \\
\text { cyclophosphamide }\end{array}$ \\
\hline Outcomes & Safety \\
Immune responses \\
Tumour responses
\end{tabular}

Starting date November 2006

Contact information

Notes Study completion January 2009; no published records available

\section{NCT00803569}

Trial name or title

Phase I study of ALVAC(2)-NY-ESO-1(M)/TRICOM in patients with epithelial ovarian, fallopian tube, or primary peritoneal carcinoma whose tumours express NY-ESO-1 or LAGE-1 antigen

\begin{tabular}{ll}
\hline Methods & Phase I \\
\hline Participants & $\begin{array}{l}\text { 12 stage II-IV women with ovarian cancer with complete response to primary or secondary } \\
\text { (chemo)therapy }\end{array}$ \\
\hline Interventions & SC ALVAC(2)-NY-ESO-1(M)/TRICOM vaccine plus SC GM-CSF \\
\hline Outcomes & Safety \\
& Tumour responses \\
& Immune responses \\
\hline Starting date & November 2008 \\
\hline
\end{tabular}


NCT00803569 (Continued)

Contact information

Notes Completed 2011; no publication available

\section{NCT01223235}

\begin{tabular}{ll}
\hline Trial name or title & Polyvalent vaccine-KLH conjugate + Opt-821 given in combination with bevacizumab \\
\hline Methods & Uncontrolled phase I \\
\hline Participants & $\begin{array}{l}22 \text { participants who have recently completed chemotherapy and/or surgery for recurrent epithelial } \\
\text { carcinoma arising from the ovary, fallopian tube, or peritoneum }\end{array}$ \\
\hline Interventions & Bevacizumab and polyvalent vaccine KLH-conjugate + OPT-821 \\
\hline Outcomes & Adverse events \\
& $\begin{array}{l}\text { Immune responses } \\
\text { Survival }\end{array}$ \\
\hline Starting date & October 2010 \\
\hline Notes & Completed September 2017; no publication available \\
\hline
\end{tabular}

\section{NCT01322802}

\begin{tabular}{ll}
\hline Trial name or title & Vaccine therapy in treating patients with stage III-IV or recurrent ovarian cancer \\
\hline Methods & Uncontrolled phase I \\
\hline Participants & $\begin{array}{l}22 \text { participants with advanced-stage or recurrent ovarian cancer treated to complete remission } \\
\text { with standard therapies }\end{array}$ \\
\hline Interventions & pUMVC3-hIGFBP-2 multi-epitope plasmid DNA vaccine \\
\hline Outcomes & Adverse events \\
& Immune responses \\
\hline Starting date & Survival \\
\hline Contact information & March 2012 \\
\hline Notes & Active April 2017; not recruiting \\
\hline
\end{tabular}


NCT01376505

\begin{tabular}{ll}
\hline Trial name or title & Vaccine therapy in treating patients with metastatic solid tumors \\
\hline Methods & Uncontrolled phase I trial \\
\hline Participants & $\begin{array}{l}\text { 36 participants with malignant solid tumour, breast cancer, malignant tumour of colon, GIST, or } \\
\text { ovarian cancer }\end{array}$ \\
\hline Interventions & HER-2 vaccine \\
\hline Outcomes & Immune response \\
& Clinical response \\
\hline Starting date & Adverse events \\
\hline Contact information & June 2011 \\
\hline Notes & Recruiting, April 2018 \\
\hline
\end{tabular}

\section{NCT01522820}

\begin{tabular}{ll}
\hline Trial name or title & $\begin{array}{l}\text { Vaccine therapy with or without sirolimus in treating patients with NY-ESO-1-expressing solid tu- } \\
\text { mours }\end{array}$ \\
\hline Methods & Uncontrolled phase I \\
\hline Participants & $\begin{array}{l}30 \text { participants with solid NY-ESO-1- or LAGE-1-expressing tumours at high risk of recurrence or } \\
\text { with minimal residual disease }\end{array}$ \\
\hline Interventions & Intranodal injections with DEC-205-NY-ESO-1 fusion protein vaccine with or without oral sirolimus \\
\hline Outcomes & Adverse events \\
& Immune responses \\
\hline Starting date & Survival \\
\hline Contact information & March 2012 \\
\hline Notes & Completed October 2016; no publication available \\
\hline
\end{tabular}

\section{NCT01536054}

Trial name or title

Sirolimus and vaccine therapy in treating patients with stage II-IV ovarian epithelial, fallopian tube, or primary peritoneal cavity cancer

Methods Uncontrolled phase I


NCT01536054 (Continued) $\begin{array}{ll}\text { Participants } & \begin{array}{l}12 \text { women with completed therapy for primary or recurrent disease with asymptomatic residual } \\ \text { disease or complete remission }\end{array}\end{array}$

\begin{tabular}{ll}
\hline Interventions & $\begin{array}{l}\text { Subcutaneous injections with ALVAC(2)-NY-ESO-1 (M)/TRICOM vaccine, subcutaneous GM-CSF, and } \\
\text { oral sirolimus }\end{array}$ \\
\hline Outcomes & Adverse events \\
& Immune responses \\
& Survival \\
\hline
\end{tabular}

Starting date August 2012

Contact information

Notes $\quad$ Active not recruiting, March 2017

\section{NCT01556841}

\section{Trial name or title}

A phase II study to assess the activity of $\operatorname{TroVax}^{\circledR}$ (MVA-5T4) versus placebo in patients with relapsed asymptomatic epithelial ovarian, fallopian tube, or primary peritoneal cancer

\begin{tabular}{ll}
\hline Methods & Randomised phase II \\
\hline Participants & 97 participants with CA-125-relapsed asymptomatic ovarian cancer \\
\hline Interventions & Vaccine targeting 5T4 (TroVax) vs placebo \\
\hline Outcomes & Clinical response \\
& Immune response \\
\hline Starting date & Survival \\
\hline Contact information & November 2013 \\
\hline Notes & Active, not recruiting, December 2017 \\
\hline
\end{tabular}

\section{NCT01584115}

$\begin{array}{ll}\text { Trial name or title } & \begin{array}{l}\text { Clinical trial of therapeutic vaccine with NY-ESO-1 in combination with the adjuvant monophos- } \\ \text { phoryl lipid A (MPLA) }\end{array}\end{array}$

\begin{tabular}{ll}
\hline Methods & Uncontrolled phase I/II \\
\hline Participants & 15 participants with a NY-ESO-1-expressing malignancy after standard treatment \\
\hline Interventions & Intramuscular injection with NY-ESO-1 combined with MPLA vaccine \\
\hline Outcomes & Adverse events \\
\hline
\end{tabular}


NCT01584115 (Continued)

Immune responses

Starting date July 2012

Contact information

Notes Status unknown

\section{NCT01606241}

Trial name or title

Cyclophosphamide and vaccine therapy in treating patients with stage II-III breast, ovarian, primary peritoneal, or fallopian tube cancer

\begin{tabular}{ll}
\hline Methods & Uncontrolled phase I \\
\hline Participants & $\begin{array}{l}24 \text { women in complete remission after systemic treatment of breast, ovarian, primary peritoneal, } \\
\text { or fallopian tube cancer }\end{array}$ \\
\hline Interventions & Oral cyclophosphamide and intradermal multi-epitope folate receptor alpha peptide vaccine \\
\hline Outcomes & Adverse events \\
& Immune responses \\
\hline Starting date & July 2012 \\
\hline Contact information & Manuscript submitted January 2018 \\
\hline
\end{tabular}

\section{NCT01616303}

Trial name or title $\quad \begin{aligned} & \text { A controlled study of effectiveness of oregovomab (antibody) plus chemotherapy in advanced } \\ & \text { ovarian cancer }\end{aligned}$

\begin{tabular}{ll}
\hline Methods & Randomised open-label phase II \\
\hline Participants & $\begin{array}{l}80 \text { women with newly diagnosed ovarian, tubal, or peritoneal cancer after optimal cytoreductive } \\
\text { surgery about to start first-line chemotherapy }\end{array}$ \\
\hline Interventions & Carboplatin + paclitaxel vs carboplatin + paclitaxel + oregovomab \\
\hline Outcomes & Adverse events \\
& Immune responses \\
& Survival \\
Clinical responses
\end{tabular}

\begin{tabular}{ll}
\hline Starting date $\quad$ June 2012 \\
\hline Contact information
\end{tabular}


NCT01616303 (Continued)

Notes $\quad$ Active not recruiting, September 2017

NCT01621542

\begin{tabular}{ll}
\hline Trial name or title & Clinical study of WT2725 in patients with advanced solid malignancies \\
\hline Methods & Uncontrolled phase I \\
\hline Participants & 80 participants with measurable WT1-expressing advanced-stage malignancies \\
\hline Interventions & WT2725 injection \\
\hline Outcomes & Adverse events \\
\hline Starting date & Immune responses \\
\hline Contact information & July 2012 \\
\hline Notes & Completed June 2017; no publication available \\
\hline
\end{tabular}

\section{NCT01673217}

\begin{tabular}{ll}
\hline Trial name or title & $\begin{array}{l}\text { Decitabine, vaccine therapy, and pegylated liposomal doxorubicin hydrochloride in treating pa- } \\
\text { tients with recurrent ovarian epithelial cancer, fallopian tube cancer, or peritoneal cancer }\end{array}$ \\
\hline Methods & Uncontrolled phase I \\
\hline Participants & $\begin{array}{l}18 \text { women with relapsed epithelial ovarian, fallopian tube, or primary peritoneal cancer who are to } \\
\text { receive liposomal doxorubicin as salvage therapy for recurrent disease }\end{array}$ \\
\hline Interventions & $\begin{array}{l}\text { Intravenous decitabine, intravenous liposomal doxorubicin, subcutaneous NY-ESO-1 peptide vac- } \\
\text { cine in Montanide ISA-51, subcutaneous GM-CSF }\end{array}$ \\
\hline Outcomes & Adverse events \\
Immune responses \\
Survival
\end{tabular}

\section{NCT02111941} cell vaccination in patients with advanced stage epithelial ovarian cancer 
NCT02111941 (Continued)

\begin{tabular}{ll} 
Methods & Uncontrolled phase I \\
\hline Participants & $\begin{array}{l}19 \text { women with stage IIIC-IV ovarian epithelial, fallopian tube, or primary peritoneal cavity cancer } \\
\text { following surgery and chemotherapy }\end{array}$ \\
\hline Interventions & Multi-epitope folate receptor alpha-loaded dendritic cell vaccine \\
\hline Outcomes & Adverse events \\
Survival & Immune response
\end{tabular}

\begin{tabular}{ll}
\hline Starting date & April 2014 \\
\hline Contact information & \\
\hline Notes & Active not recruiting, October 2017 \\
\hline
\end{tabular}

\section{NCT02132988}

Trial name or title

An open labeled phase II trial of active immunotherapy with Globo H-KLH (OPT-822/821) in women who have non-progressive epithelial ovarian, fallopian tube, or primary peritoneal cancer

\begin{tabular}{ll}
\hline Methods & Phase II \\
\hline Participants & $\begin{array}{l}110 \text { participants with non-progressive epithelial ovarian, fallopian tube, or primary peritoneal can- } \\
\text { cer after cytoreductive surgery and platinum-based chemotherapy as initial treatment for primary } \\
\text { disease or as salvage treatment for first relapse }\end{array}$ \\
\hline Interventions & Globo H-KLH vaccine (OPT-822/OPT-821) \\
\hline Outcomes & Progression-free survival \\
\hline Starting date & Disease recurrence rate \\
\hline Contact information & November 2013 \\
\hline Notes & Recruiting, May 2014 \\
\hline
\end{tabular}

\section{NCT02146313}

Trial name or title

A phase I, open-label, dose-escalation study of the safety, tolerability, and pharmacokinetics of DMUC4064A administered intravenously to patients with platinum-resistant ovarian cancer or unresectable pancreatic cancer

\begin{tabular}{ll}
\hline Methods & Non-randomised phase I \\
\hline Participants & 30 participants with platinum-resistant ovarian cancer or unresectable pancreatic cancer \\
\hline Interventions & Intravenous DMUC4064A \\
\hline
\end{tabular}


NCT02146313 (Continued)

DLT
Adverse events
Immune response
Clinical response

\begin{tabular}{ll}
\hline Starting date & May 2014 \\
\hline Contact information & \\
\hline Notes & Active not recruiting, March 2018 \\
\hline
\end{tabular}

\section{NCT02166905}

$\begin{array}{ll}\text { Trial name or title } & \text { A phase I/IIb study of DEC205mAb-NY-ESO-1 fusion protein (CDX-1401) given with adjuvant poly- } \\ \text { ICLC in combination with INCB024360 for patients in remission with epithelial ovarian, fallopian } \\ \text { tube, or primary peritoneal carcinoma whose tumors express NY-ESO-1 or LAGE-1 antigen }\end{array}$

\begin{tabular}{ll}
\hline Methods & Phase II and randomised phase Ilb \\
\hline Participants & $\begin{array}{l}62 \text { participants with epithelial ovarian, fallopian tube, or primary peritoneal carcinoma whose tu- } \\
\text { mours express NY-ESO-1 or LAGE-1 antigen }\end{array}$ \\
\hline
\end{tabular}

Phase I:
DEC-205/NY-ESO-1 fusion protein CDX-1401, poly ICLC, and IDO1 inhibitor INCB024360
Phase IIb cohort I: DEC-205/NY-ESO-1 fusion protein CDX-1401 and poly ICLC
Phase IIB cohort II: DEC-205/NY-ESO-1 fusion protein CDX-1401, poly ICLC, and IDO1 inhibitor
INCB024360

\begin{tabular}{ll}
\hline Outcomes & $\begin{array}{l}\text { Adverse events } \\
\text { Immune response }\end{array}$ \\
\hline Starting date & August 2014 \\
\hline Contact information & \\
\hline Notes & Recruiting, May 2018 \\
\hline
\end{tabular}

\section{NCT02275039}

\begin{tabular}{ll}
\hline Trial name or title & A phase I study of a p53MVA vaccine in combination with gemcitabine in ovarian cancer \\
\hline Methods & Uncontrolled phase I \\
\hline Participants & 9 participants with recurrent epithelial ovarian, fallopian tube, or primary peritoneal carcinoma \\
\hline Interventions & Vaccinia virus ankara vaccine expressing p53 and gemcitabine hydrochloride \\
\hline Outcomes & Dosage determination \\
\hline
\end{tabular}


NCT02275039 (Continued)

Immune response

\begin{tabular}{ll}
\hline Starting date & October 2014 \\
\hline Contact information & \\
\hline Notes & Completed, April 2018 \\
\hline
\end{tabular}

\section{NCT02387125}

\section{Trial name or title}

A phase Ib study evaluating the safety, tolerability and immunogenicity of CMB305 (sequentially administered LV305 and G305) in patients with locally advanced, relapsed, or metastatic cancer expressing NY-ESO-1

\begin{tabular}{ll}
\hline Methods & Non-randomised open-label multi-centre phase Ib \\
\hline Participants & $\begin{array}{l}69 \text { participants with melanoma, sarcoma, ovarian cancer, or non-small cell lung cancer that ex- } \\
\text { presses NY-ESO-1 }\end{array}$ \\
\hline Interventions & $\begin{array}{l}\text { CMB305 (sequentially administered LV305 (a dendritic cell-targeting viral vector expressing the NY- } \\
\text { ESO-1 gene) and G305 (NY-ESO-1 recombinant protein plus GLA-SE)) }\end{array}$ \\
\hline Outcomes & Adverse events \\
& Clinical response \\
& Survival \\
Immune response \\
\hline Starting date & March 2015 \\
\hline Notes & Recruiting, January 2018 \\
\hline
\end{tabular}

\section{NCT02498665}

\begin{tabular}{ll}
\hline Trial name or title & $\begin{array}{l}\text { A phase I clinical study of DSP-7888 dosing emulsion in adult patients with advanced malignan- } \\
\text { cies }\end{array}$ \\
\hline Methods & Non-randomised phase I \\
\hline Participants & 96 participants with advanced malignancies \\
\hline Interventions & WT1 protein-derived peptide vaccine (DSP-7888) \\
\hline Outcomes & DLT \\
& Survival \\
Immune response
\end{tabular}

Starting date November 2015


NCT02498665 (Continued)

Contact information

Notes Recruiting, April 2018

\section{NCT02575807}

Trial name or title

A phase I/II open-label safety and efficacy evaluation of CRS-207 in combination with epacadostat in adults with platinum-resistant ovarian, fallopian, or peritoneal cancer

\begin{tabular}{|c|c|}
\hline Methods & Randomised phase I/II \\
\hline Participants & 126 participants with platinum-resistant ovarian, fallopian, or peritoneal cancer \\
\hline \multirow[t]{8}{*}{ Interventions } & Phase I cohort I: \\
\hline & CRS-207/epacadostat \\
\hline & Phase I cohort II: \\
\hline & CRS-207 \\
\hline & Phase 2 cohort I: \\
\hline & CRS-207, pembrolizumab \\
\hline & Phase II cohort II: \\
\hline & CRS-207, pembrolizumab, epacadostat \\
\hline \multirow[t]{4}{*}{ Outcomes } & DLT \\
\hline & Adverse events \\
\hline & Clinical response \\
\hline & Survival \\
\hline Starting date & October 2015 \\
\hline \multicolumn{2}{|c|}{ Contact information } \\
\hline Notes & Active not recruiting, February 2018 \\
\hline
\end{tabular}

\section{NCT02737787}

\begin{tabular}{ll}
\hline Trial name or title & $\begin{array}{l}\text { A phase I study of concomitant WT1 analog peptide vaccine with Montanide and GM-CSF in com- } \\
\text { bination with nivolumab in patients with recurrent ovarian cancer who are in second or greater re- } \\
\text { mission }\end{array}$ \\
\hline Methods & Uncontrolled phase I \\
\hline Participants & 10 participants with ovarian, fallopian tube, or primary peritoneal cancer \\
\hline Interventions & WT1 vaccine and nivolumab \\
\hline Outcomes & Dose-limiting toxicity \\
\hline
\end{tabular}


NCT02737787 (Continued)
Starting date
April 2016

\section{Contact information}

Notes Active not recruiting, March 2018

\section{NCT02764333}

\begin{tabular}{ll}
\hline Trial name or title & $\begin{array}{l}\text { A phase II trial of TPIV200/huFR-1 (a multi-epitope anti-folate receptor vaccine) plus anti-PD-L1 } \\
\text { MEDI4736 (durvalumab) in patients with platinum-resistant ovarian cancer }\end{array}$ \\
\hline Methods & Uncontrolled phase II \\
\hline Participants & 40 participants with epithelial ovarian, fallopian tube, or primary peritoneal carcinoma \\
\hline Interventions & $\begin{array}{l}\text { Intradermal TPIV200 (vaccine targeting folate receptor alpha mixed with GM-CSF) and intravenous } \\
\text { durvalumab }\end{array}$ \\
\hline Outcomes & Clinical response \\
\hline Starting date & May 2016 \\
\hline Contact information & Active not recruiting, March 2018 \\
\hline Notes &
\end{tabular}

\section{NCT02785250}

\begin{tabular}{ll}
\hline Trial name or title & $\begin{array}{l}\text { A phase lb study of an immunotherapeutic vaccine, DPX-Survivac with low dose cyclophosphamide } \\
\text { and epacadostat (INCB024360), in patients with recurrent ovarian cancer }\end{array}$ \\
\hline Methods & Uncontrolled phase I \\
\hline Participants & 40 participants with recurrent epithelial ovarian, fallopian tube, or peritoneal cancer \\
\hline Interventions & Survivin vaccine DPX-Survivac, low-dose oral cyclophosphamide, and IDO1 inhibitor epacadostat \\
\hline Outcomes & Adverse events \\
& Immune response \\
Clinical response & Survival \\
\hline Starting date & May 2016 \\
\hline Contact information & Recruiting, June 2017 \\
\hline Notes &
\end{tabular}


NCT02833506

\begin{tabular}{ll}
\hline Trial name or title & $\begin{array}{l}\text { A phase I clinical trial of mTOR inhibition with sirolimus for enhancing NY-ESO-1 protein with } \\
\text { MIS416 vaccine induced anti-tumor immunity in ovarian, fallopian tube, and primary peritoneal } \\
\text { cancer }\end{array}$ \\
\hline Methods & Non-randomised phase I \\
\hline Participants & 12 participants with stage II-IV ovarian, fallopian tube, or primary peritoneal cancer \\
\hline Interventions & Cohort 1: NY-ESO-1 protein with MIS416 \\
\hline Cutcomes & Cohort 2: sirolimus and NY-ESO-1 protein with MIS416 \\
& Adverse events \\
\hline Immune response \\
\hline Clinical response \\
\hline Notes & December 2017 \\
\hline
\end{tabular}

\section{NCT02933073}

\begin{tabular}{ll}
\hline Trial name or title & A phase I study of Oncolmmunome for the treatment of stage III/IV ovarian carcinoma \\
\hline Methods & Uncontrolled phase I \\
\hline Participants & 15 participants \\
\hline Interventions & $\begin{array}{l}\text { Personalised vaccine containing a mixture of } 7 \text { to } 10 \text { peptides, each containing } 17 \text { or } 18 \text { amino } \\
\text { acids (Oncolmmunome) }\end{array}$ \\
\hline Outcomes & Adverse events \\
& Immune response \\
Survival
\end{tabular}

\begin{tabular}{ll}
\hline Starting date & November 2016 \\
\hline Contact information & \\
\hline Notes & Recruiting, July 2017 \\
\hline
\end{tabular}

\section{NCT02978222}

\begin{tabular}{ll}
\hline Trial name or title & $\begin{array}{l}\text { A randomized multicenter phase II trial to evaluate the safety, efficacy and immunogenicity of vac- } \\
\text { cination with folate receptor alpha peptides with GM-CSF versus GM-CSF alone in patients with } \\
\text { platinum sensitive ovarian cancer and a response or stable disease to platinum therapy }\end{array}$ \\
\hline Methods & Multi-centre double-blind controlled randomised phase II study \\
\hline \hline Antigen-specific active immunotherapy for ovarian cancer (Review) \\
Copyright $\odot 2018$ The Cochrane Collaboration. Published by John Wiley \& Sons, Ltd.
\end{tabular}

\footnotetext{
Copyright @ 2018 The Cochrane Collaboration. Published by John Wiley \& Sons, Ltd.
} 
NCT02978222 (Continued)

Participants 120 participants with platinum-sensitive ovarian cancer

\begin{tabular}{ll}
\hline Interventions & FRa peptide vaccine with GM-CSF or GM-CSF alone \\
\hline Outcomes & Survival \\
& Clinical response \\
\hline Starting date & November 2016 \\
\hline Contact information & \\
\hline Notes & Recruting, April 2018 \\
\hline
\end{tabular}

\section{NCT03029403}

\begin{tabular}{ll}
\hline Trial name or title & $\begin{array}{l}\text { A phase II study of pembrolizumab (MK-3475), DPX-Survivac vaccine and low dose of cyclophos- } \\
\text { phamide combination in patients with advanced ovarian, primary peritoneal or fallopian tube can- } \\
\text { cer }\end{array}$ \\
\hline Methods & Non-randomised phase II \\
\hline Participants & \begin{tabular}{l} 
42 participants with advanced ovarian, primary peritoneal, or fallopian tube cancer \\
\hline Interventions
\end{tabular} \\
\hline $\begin{array}{l}\text { Intravenous pembrolizumab, subcutaneous DPX-Survivac vaccine, and oral low-dose cyclophos- } \\
\text { phamide }\end{array}$ \\
\hline Outcomes & Sverall response rate \\
\hline Starting date & Adverse events \\
\hline Contact information & January 2017 \\
\hline Notes & Recruiting, May 2018 \\
\hline
\end{tabular}

\section{NCT03029611}

\begin{tabular}{ll}
\hline Trial name or title & $\begin{array}{l}\text { A phase II study of concurrent IGFBP-2 vaccination and neoadjuvant chemotherapy to increase the } \\
\text { rate of pathologic complete response at the time of cytoreductive surgery }\end{array}$ \\
\hline Methods & Uncontrolled phase II \\
\hline Participants & 38 participants with fallopian tube cancer, ovarian cancer, or primary peritoneal cancer \\
\hline Interventions & Intravenous paclitaxel and carboplatin, intradermal IGFBP-2 vaccine \\
\hline Outcomes & Clinical response \\
& Immune response \\
\hline
\end{tabular}


NCT03029611 (Continued)

Starting date

April 2017

\section{Contact information}

Notes Recruiting, May 2018

\section{NCT03113487}

$\begin{array}{ll}\text { Trial name or title } & \begin{array}{l}\text { A phase II study of a P53MVA vaccine in combination with pembrolizumab in platinum resistant } \\ \text { ovarian cancer }\end{array}\end{array}$

\begin{tabular}{ll}
\hline Methods & Uncontrolled phase II trial \\
\hline Participants & 28 participants with ovarian, primary peritoneal, or fallopian tube cancer \\
\hline Interventions & Vaccinia virus ankara vaccine expressing p53 (p53MVA) and pembrolizumab \\
\hline Outcomes & Clinical response \\
& Survival \\
\hline
\end{tabular}

Starting date March 2017

\section{Contact information}

Notes Not yet recruiting, April 2018

\section{NCT03127098}

Trial name or title

Phase Ib/ll study of ETBX-011 (Ad5 (E1-, E2b-)-CEA(6D)) vaccine in combination with ALT-803 (super-agonist IL-15) in subjects having CEA-expressing cancer

\begin{tabular}{ll}
\hline Methods & Phase Ib/II \\
\hline Participants & 3 participants with locally advanced or metastatic CEA-expressing cancers \\
\hline Interventions & Subcutaneous ETBX-011 and subcutaneous ALT-803. \\
\hline Outcomes & Adverse events \\
\hline Starting date & Survival \\
\hline Contact information & April 2017 \\
\hline Notes & Active not recruiting, June 2018 \\
\hline
\end{tabular}




\section{NCT03197584}

Trial name or title

NANT ovarian cancer vaccine: combination immunotherapy in subjects with epithelial ovarian cancer who have progressed on or after standard-of-care (SoC) therapy

\begin{tabular}{ll}
\hline Methods & Uncontrolled phase Ib/II \\
\hline Participants & 67 participants with epithelial ovarian cancer \\
\hline Interventions & $\begin{array}{l}\text { Avelumab, bevacizumab, capecitabine, cyclophosphamide, 5-fluorouracil, fulvestrant, leucovorin, } \\
\text { paclitaxel, omega-3-acid ethyl esters, oxaliplatin, stereotactic body radiation therapy, ALT-803, ET- } \\
\text { BX-021, ETBX-051, ETBX-061, GI-4000, GI-6301, and hank }\end{array}$ \\
\hline Outcomes & Adverse events \\
& Response rate (RECIST) \\
\hline Immune response \\
\hline Contact information & June 2017 \\
\hline Notes & Not yet recruiting, October 2017 \\
\hline
\end{tabular}

\section{NCT03206047}

\begin{tabular}{|c|c|}
\hline Trial name or title & $\begin{array}{l}\text { A randomized phase II trial of atezolizumab (MPDL3280A), SGI-110 and CDX-1401 vaccine in recur- } \\
\text { rent ovarian cancer }\end{array}$ \\
\hline Methods & Randomised phase $\mathrm{l} / \mathrm{Ilb}$ \\
\hline Participants & 78 participants \\
\hline \multirow[t]{3}{*}{ Interventions } & Cohort 1: intravenous atezolizumab \\
\hline & Cohort 2: intravenous atezolizumab and subcutaneous guadecitabine \\
\hline & $\begin{array}{l}\text { Cohort 3: intravenous atezolizumab, subcutaneous guadecitabine, and DEC-205/NY-ESO-1 fusion } \\
\text { protein CDX-1401 }\end{array}$ \\
\hline \multirow[t]{4}{*}{ Outcomes } & Adverse events \\
\hline & Survival \\
\hline & Immune response \\
\hline & Clinical response \\
\hline Starting date & September 2017 \\
\hline \multicolumn{2}{|c|}{ Contact information } \\
\hline Notes & Recruiting, June 2018 \\
\hline
\end{tabular}


NCT03300843

\begin{tabular}{|c|c|}
\hline Trial name or title & $\begin{array}{l}\text { A phase II trial to evaluate the ability of a dendritic cell vaccine to immunize melanoma or epithelial } \\
\text { cancer patients against defined mutated neoantigens expressed by the autologous cancer }\end{array}$ \\
\hline Participants & $\begin{array}{l}86 \text { participants with evaluable metastatic melanoma or epithelial cancer refractory to standard } \\
\text { treatment }\end{array}$ \\
\hline Interventions & Personalised therapeutic dendritic cell vaccine \\
\hline \multirow[t]{3}{*}{ Outcomes } & Clinical response \\
\hline & Immune response \\
\hline & Adverse events \\
\hline Starting date & October 2017 \\
\hline \multicolumn{2}{|c|}{ Contact information } \\
\hline Notes & Recruiting, May 2018 \\
\hline
\end{tabular}

CA-125: cancer antigen-125.

CEA: carcinoembryonic antigen.

DLT: dose-limiting toxicity.

GIST: gastrointestinal stromal tumour.

GM-CSF: granulocyte-macrophage colony-stimulating factor.

$\mathrm{KLH}$ : keyhole limpet haemocyanin.

MPLA: monophosphoryl lipid A.

MUC1: Mucin-1.

RECIST: Response Evaluation Criteria In Solid Tumors.

\section{ADDITIONAL TABLES}

Table 1. Study report to assess quality of non-randomised, non-controlled studies

\begin{tabular}{lll}
\hline Item & Question & Evaluation \\
\hline 1. & Sample definition and selection & Yes No? \\
a. & Are inclusion and exclusion criteria clearly defined? & Yes No? \\
b. & Is the study population a representative selection of the true population? & Yes No? \\
c. & Are baseline characteristics adequately described? & \\
\hline
\end{tabular}

\begin{tabular}{lll}
\hline 2 & Interventions & Yes No? \\
a. & $\begin{array}{l}\text { Are the interventions clearly defined (type of vaccine, antigen, adjuvant, route } \\
\text { of vaccination, and vaccination schedule)? }\end{array}$ & Yes No? \\
b. & Did patients receive concurrent/concomitant treatment with immunomodula- \\
& tory effects? & Outcomes \\
\hline 3 & Are the selected outcome measures clearly specified? & Yes No? \\
a. & & Yes No?
\end{tabular}


Table 1. Study report to assess quality of non-randomised, non-controlled studies (Continued)
b.
Are the outcome measures relevant?
Yes No?

c.

Are the outcome measures clearly reported?

$\begin{array}{lll}\text { 4. } & \text { Statistical analysis } & \text { Yes No ? } \\ \text { a. } & \text { Is there an adequate rationale for the number of participants included? } & \text { Yes No? } \\ \text { b. } & \text { Is there an adequate description of withdrawal/exclusion of participants dur- } & \text { Yes No? } \\ \text { c. } & \text { ing the study? } & \text { Is presentation of the results adequate? }\end{array}$

Table 2. Overview of included studies

\begin{tabular}{|c|c|c|c|c|c|}
\hline Study & Design & $\mathbf{N}$ & Disease status & Target antigen & $\begin{array}{l}\text { Type of interven- } \\
\text { tion }\end{array}$ \\
\hline Antonilli 2016 & $\begin{array}{l}\text { Uncontrolled } \\
\text { phase I/II }\end{array}$ & 10 & $\begin{array}{l}\text { No evidence of disease }(n=7)+\text { re- } \\
\text { current disease }(n=3)\end{array}$ & $\begin{array}{l}\text { MUC1 } \pm \text { ErbB2 } \pm \\
\text { CEA }\end{array}$ & $\begin{array}{l}\text { Multi-peptide vac- } \\
\text { cine }\end{array}$ \\
\hline $\begin{array}{l}\text { Baumann } \\
2011\end{array}$ & $\mathrm{RCT}$ & 45 & $\begin{array}{l}\text { Evidence of disease after first- and/ } \\
\text { or second-line chemotherapy }\end{array}$ & EрCAM & $\begin{array}{l}\text { Antibody (low dose } \\
\text { vs high dose) }\end{array}$ \\
\hline Berek 2001 & $\mathrm{RCT}$ & 252 & $\begin{array}{l}\text { No evidence of disease after pri- } \\
\text { mary surgery and chemotherapy }\end{array}$ & CA-125 & $\begin{array}{l}\text { Antibody vs place- } \\
\text { bo }\end{array}$ \\
\hline Berek 2004 & $\mathrm{RCT}$ & 145 & $\begin{array}{l}\text { No evidence of disease after pri- } \\
\text { mary surgery and chemotherapy }\end{array}$ & CA-125 & $\begin{array}{l}\text { Antibody vs place- } \\
\text { bo }\end{array}$ \\
\hline Berek 2009 & $\mathrm{RCT}$ & 317 & $\begin{array}{l}\text { No evidence of disease after pri- } \\
\text { mary surgery and chemotherapy }\end{array}$ & CA-125 & $\begin{array}{l}\text { Antibody vs place- } \\
\text { bo }\end{array}$ \\
\hline $\begin{array}{l}\text { Berinstein } \\
2012\end{array}$ & $\begin{array}{l}\text { Uncontrolled } \\
\text { phase I }\end{array}$ & 6 & $\begin{array}{l}\text { (No) evidence of disease after pri- } \\
\text { mary surgery }\end{array}$ & $\begin{array}{l}\text { Topoisomerase } \\
\text { Ila, integrin } \beta 8 \\
\text { subunit precur- } \\
\text { sor, ABI-bind- } \\
\text { ing protein C3, } \\
\text { TACE/ADAM17, } \\
\text { junction plak- } \\
\text { globin, EDDR1, } \\
\text { BAP31 }\end{array}$ & Short peptides \\
\hline $\begin{array}{l}\text { Berinstein } \\
2013\end{array}$ & $\begin{array}{l}\text { Uncontrolled } \\
\text { phase I }\end{array}$ & 19 & Unknown & Survivin & Short peptides \\
\hline Braly 2009 & $\mathrm{RCT}$ & 40 & $\begin{array}{l}\text { (No) evidence of disease after pri- } \\
\text { mary surgery }\end{array}$ & CA-125 & $\begin{array}{l}\text { Antibody (concur- } \\
\text { rent or delayed } \\
\text { with standard } \\
\text { chemotherapy) }\end{array}$ \\
\hline Brossart 2000 & $\begin{array}{l}\text { Uncontrolled } \\
\text { phase I/II }\end{array}$ & 3 & Residual or recurrent disease & $\begin{array}{l}\text { Her-2/Neu or } \\
\text { MUC1 }\end{array}$ & $\begin{array}{l}\text { Peptide-pulsed } \\
\text { dendritic cells }\end{array}$ \\
\hline $\begin{array}{l}\text { Buzzonetti } \\
2014\end{array}$ & $\mathrm{RCT}$ & 129 & $\begin{array}{l}\text { No evidence of disease after pri- } \\
\text { mary treatment }\end{array}$ & CA-125 & $\begin{array}{l}\text { Antibody vs place- } \\
\text { bo }\end{array}$ \\
\hline
\end{tabular}


Table 2. Overview of included studies (Continued)

\begin{tabular}{lllll}
$\begin{array}{l}\text { Chianese-Bul- } \\
\text { lock 2008 }\end{array}$ & $\begin{array}{l}\text { Uncontrolled } \\
\text { phase I }\end{array}$ & 9 & $\begin{array}{l}\text { (No) evidence of disease or recur- } \\
\text { rence after primary therapy }\end{array}$ & $\begin{array}{l}\text { FBP, Her-2/Neu, } \\
\text { MAGE-A1 }\end{array}$ \\
\hline Chu 2012 & RCT & 11 & $\begin{array}{l}\text { No evidence of disease after pri- } \\
\text { mary therapy or surgery for first re- }\end{array}$ & $\begin{array}{l}\text { Her-2/Neu, } \\
\text { hTERT, PADRE }\end{array}$ \\
& & $\begin{array}{l}\text { Peptide-pulsed } \\
\text { currence } \\
\text { (with vs without cy- } \\
\text { clophosphamide) }\end{array}$ &
\end{tabular}

\begin{tabular}{|c|c|c|c|c|c|}
\hline $\begin{array}{l}\text { Dhodapkar } \\
2012\end{array}$ & $\begin{array}{l}\text { Uncontrolled } \\
\text { phase I }\end{array}$ & 6 & Unknown & NY-ESO-1 & Fusion protein \\
\hline $\begin{array}{l}\text { Diefenbach } \\
2008\end{array}$ & $\begin{array}{l}\text { Uncontrolled } \\
\text { phase I }\end{array}$ & 9 & $\begin{array}{l}\text { No evidence of disease after pri- } \\
\text { mary surgery and chemotherapy }\end{array}$ & NY-ESO-1 & Short peptide \\
\hline Dijkgraaf 2015 & $\begin{array}{l}\text { Uncontrolled } \\
\text { phase I/II }\end{array}$ & 15 & Evidence of disease & P53 & $\begin{array}{l}\text { Synthetic long pep- } \\
\text { tides }\end{array}$ \\
\hline Ehlen 2005 & $\begin{array}{l}\text { Uncontrolled } \\
\text { phase II }\end{array}$ & 13 & Measurable recurrent disease & CA-125 & Antibody \\
\hline $\begin{array}{l}\text { Freedman } \\
1998\end{array}$ & $\mathrm{RCT}$ & 30 & Unknown & Sialyl-Tn & $\begin{array}{l}\text { KLH conjugate (low } \\
\text { dose vs high dose) }\end{array}$ \\
\hline Galanis 2010 & $\begin{array}{l}\text { Uncontrolled } \\
\text { phase I }\end{array}$ & 21 & $\begin{array}{l}\text { Persistent, recurrent, or progres- } \\
\text { sive disease after primary therapy }\end{array}$ & CEA & Recombinant virus \\
\hline Goh 2013 & $\mathrm{RCT}$ & 63 & $\begin{array}{l}\text { No evidence of disease after first- } \\
\text { or second-line therapy }\end{array}$ & MUC1 & $\begin{array}{l}\text { Protein-pulsed den- } \\
\text { dritic cells vs stan- } \\
\text { dard of care }\end{array}$ \\
\hline Gordon 2004 & $\begin{array}{l}\text { Uncontrolled } \\
\text { phase II }\end{array}$ & 20 & Recurrent disease & CA-125 & Antibody \\
\hline Gray 2016 & $\begin{array}{l}\text { Randomised } \\
\text { phase II }\end{array}$ & 56 & First or second clinical remission & MUC1 & $\begin{array}{l}\text { Dendritic cell thera- } \\
\text { py }\end{array}$ \\
\hline Gribben 2005 & $\begin{array}{l}\text { Uncontrolled } \\
\text { phase I }\end{array}$ & 6 & Evidence of disease & CYP1B1 & Plasmid DNA \\
\hline Gulley 2008 & $\begin{array}{l}\text { Uncontrolled } \\
\text { phase I/II }\end{array}$ & 3 & $\begin{array}{l}\text { Progressive disease after standard } \\
\text { chemotherapy }\end{array}$ & CEA, MUC1 & Recombinant virus \\
\hline Heiss 2010 & $\mathrm{RCT}$ & 129 & Recurrent malignant ascites & EpCAM & $\begin{array}{l}\text { Antibody + para- } \\
\text { centesis vs para- } \\
\text { centesis }\end{array}$ \\
\hline Imhof 2013 & $\begin{array}{l}\text { Uncontrolled } \\
\text { phase I }\end{array}$ & 15 & $\begin{array}{l}\text { No evidence of disease after pri- } \\
\text { mary therapy }\end{array}$ & TERT, survivin & $\begin{array}{l}\text { mRNA- and pep- } \\
\text { tide-pulsed dendrit- } \\
\text { ic cells }\end{array}$ \\
\hline $\begin{array}{l}\text { Kaumaya } \\
2009\end{array}$ & $\begin{array}{l}\text { Uncontrolled } \\
\text { phase I }\end{array}$ & 5 & $\begin{array}{l}\text { Evidence of disease after prior } \\
\text { therapy }\end{array}$ & Her-2/Neu & Long peptides \\
\hline Kawano 2014 & $\begin{array}{l}\text { Uncontrolled } \\
\text { phase II }\end{array}$ & 42 & Recurrent and persistent disease & $\begin{array}{l}\text { Personalised } \\
\text { (max } 4 \text { out of } 31 \\
\text { vaccine candi- } \\
\text { dates) }\end{array}$ & Peptides \\
\hline
\end{tabular}


Table 2. Overview of included studies (Continued)

\begin{tabular}{|c|c|c|c|c|c|}
\hline $\begin{array}{l}\text { Kobayashi } \\
2014\end{array}$ & $\begin{array}{l}\text { Uncontrolled tri- } \\
\text { al }\end{array}$ & 56 & Recurrent disease & $\begin{array}{l}\text { WT1 } 1 \pm \text { MUC1 } 1 \\
\text { CA-125 }\end{array}$ & $\begin{array}{l}\text { Peptide-pulsed DC } \\
\text { vaccine }\end{array}$ \\
\hline Le 2012 & $\begin{array}{l}\text { Uncontrolled } \\
\text { phase I }\end{array}$ & 2 & $\begin{array}{l}\text { Evidence of disease after prior } \\
\text { therapy }\end{array}$ & Mesothelin & $\begin{array}{l}\text { Recombinant bac- } \\
\text { teria }\end{array}$ \\
\hline Leffers 2009a & $\begin{array}{l}\text { Uncontrolled } \\
\text { phase II }\end{array}$ & 20 & Recurrent disease & p53 & Long peptides \\
\hline Lennerz 2014 & $\begin{array}{l}\text { Uncontrolled } \\
\text { randomised } \\
\text { phase I }\end{array}$ & 7 & (No) evidence of disease & Survivin & Five short peptides \\
\hline Letsch 2011 & Uncontrolled & 8 & Unknown & WT1 & Short peptide \\
\hline Ma 2002 & Uncontrolled & 4 & Unknown & CA-125 & Antibody \\
\hline MacLean 1992 & $\begin{array}{l}\text { Uncontrolled } \\
\text { phase I }\end{array}$ & 10 & Residual or recurrent disease & $\begin{array}{l}\text { Thomsen } \\
\text { Friedenreich }\end{array}$ & KLH conjugate \\
\hline MacLean 1996 & $\begin{array}{l}\text { Uncontrolled } \\
\text { phase II }\end{array}$ & 34 & Residual or recurrent disease & Sialyl-Tn & KLH conjugate \\
\hline Method 2002 & $\mathrm{RCT}$ & 102 & Unknown & CA-125 & $\begin{array}{l}\text { Antibody ( } 2 \text { vs } 3 \text { vs } \\
6 \text { gifts) }\end{array}$ \\
\hline Möbus 2003 & $\begin{array}{l}\text { Retrospective } \\
\text { uncontrolled }\end{array}$ & 44 & $\begin{array}{l}\text { Recurrent disease after primary } \\
\text { therapy }\end{array}$ & CA-125 & Antibody \\
\hline $\begin{array}{l}\text { Mohebtash } \\
2011\end{array}$ & Uncontrolled & 14 & $\begin{array}{l}\text { Recurrent or residual disease after } \\
\text { therapy }\end{array}$ & CEA, MUC1 & Recombinant virus \\
\hline Morse 2011 & $\begin{array}{l}\text { Uncontrolled } \\
\text { phase I }\end{array}$ & 8 & $\begin{array}{l}\text { No evidence of disease after first- } \\
\text { or second-line chemotherapy }\end{array}$ & $\begin{array}{l}\text { APC, HHR6A, } \\
\text { BAP31, repli- } \\
\text { cation pro- } \\
\text { tein A, Abl- } \\
\text { binding pro- } \\
\text { tein } 3 c \text {, cyclin I, } \\
\text { topoisomerase } \\
\text { Ila/ } \beta \text {, inte- } \\
\text { grin } \beta 8 \text { sub- } \\
\text { unit precursor, } \\
\text { CDC2, TACE, g- } \\
\text { catenin, EED- } \\
\text { DR1 }\end{array}$ & Short peptides \\
\hline $\begin{array}{l}\text { Nicholson } \\
2004\end{array}$ & $\begin{array}{l}\text { Uncontrolled } \\
\text { phase I }\end{array}$ & 26 & $\begin{array}{l}\text { Residual disease after primary } \\
\text { therapy or second complete remis- } \\
\text { sion }\end{array}$ & MUC1 & Antibody \\
\hline $\begin{array}{l}\text { Nishikawa } \\
2006\end{array}$ & $\begin{array}{l}\text { Uncontrolled } \\
\text { phase II }\end{array}$ & 4 & Unknown & NY-ESO-1 & Short peptide \\
\hline Noujaim 2001 & $\begin{array}{l}\text { Retrospective } \\
\text { uncontrolled }\end{array}$ & 184 & Recurrent disease & CA-125 & Antibody \\
\hline $\begin{array}{l}\text { O'Cearbhaill } \\
2016\end{array}$ & $\begin{array}{l}\text { Uncontrolled } \\
\text { phase I }\end{array}$ & 24 & No evidence of disease & $\begin{array}{l}\text { Globo-H, GM2, } \\
\text { sTn, TF, and Tn }\end{array}$ & $\begin{array}{l}\text { Unimolecular pen- } \\
\text { tavalent vaccine }\end{array}$ \\
\hline
\end{tabular}


Table 2. Overview of included studies (Continued)

\begin{tabular}{|c|c|c|c|c|c|}
\hline Odunsi 2007 & $\begin{array}{l}\text { Uncontrolled } \\
\text { phase I }\end{array}$ & 18 & $\begin{array}{l}\text { (No) evidence of disease after } \\
\text { chemotherapy for primary or re- } \\
\text { current disease }\end{array}$ & NY-ESO-1 & Short peptide \\
\hline Odunsi 2012 & $\begin{array}{l}\text { Uncontrolled } \\
\text { phase } 1 / / 1\end{array}$ & 22 & $\begin{array}{l}\text { No evidence of disease after pri- } \\
\text { mary therapy }\end{array}$ & NY-ESO-1 & Recombinant virus \\
\hline Odunsi 2014 & $\begin{array}{l}\text { Uncontrolled } \\
\text { phase I/II }\end{array}$ & 12 & Recurrent epithelial cancer & NY-ESO-1 & $\begin{array}{l}\text { Protein vaccine } \\
\text { with Montanide }\end{array}$ \\
\hline Ohno 2009 & $\begin{array}{l}\text { Uncontrolled } \\
\text { phase II }\end{array}$ & 6 & Unknown & WT1 & Short peptide \\
\hline $\begin{array}{l}\text { Peetham- } \\
\text { baram } 2009\end{array}$ & $\begin{array}{l}\text { Uncontrolled } \\
\text { phase II }\end{array}$ & 4 & Progressive disease after therapy & Her-2/Neu & $\begin{array}{l}\text { Fusion protein } \\
\text { pulsed antigen-pre- } \\
\text { senting cells }\end{array}$ \\
\hline Pfisterer 2006 & $\begin{array}{l}\text { Uncontrolled } \\
\text { phase I }\end{array}$ & 36 & Unknown & CA-125 & Antibody \\
\hline Rahma 2012 & $\begin{array}{l}\text { Uncontrolled } \\
\text { phase II }\end{array}$ & 21 & No evidence of disease & p53 & $\begin{array}{l}\text { Short peptide vs } \\
\text { peptide-pulsed } \\
\text { dendritic cells }\end{array}$ \\
\hline Reinartz 2004 & $\begin{array}{l}\text { Uncontrolled } \\
\text { phase } \mathrm{Ib} / \mathrm{II}\end{array}$ & 119 & Unknown & CA-125 & Antibody \\
\hline $\begin{array}{l}\text { Sabbatini } \\
2000\end{array}$ & $\begin{array}{l}\text { Uncontrolled } \\
\text { phase I }\end{array}$ & 25 & $\begin{array}{l}\text { No evidence of disease after } \\
\text { chemotherapy for primary or re- } \\
\text { current disease }\end{array}$ & MUC1 & KLH conjugate \\
\hline $\begin{array}{l}\text { Sabbatini } \\
2006\end{array}$ & $\mathrm{RCT}$ & 42 & $\begin{array}{l}\text { (No) evidence of disease }(<2 \mathrm{~cm}) \\
\text { after chemotherapy for recurrent } \\
\text { disease }\end{array}$ & CA-125 & $\begin{array}{l}\text { Antibody (intra- } \\
\text { muscular vs subcu- } \\
\text { taneous) }\end{array}$ \\
\hline $\begin{array}{l}\text { Sabbatini } \\
2007\end{array}$ & $\begin{array}{l}\text { Uncontrolled } \\
\text { phase } 1 / / 1\end{array}$ & 11 & $\begin{array}{l}\text { No evidence of disease after } \\
\text { chemotherapy for primary or re- } \\
\text { current disease }\end{array}$ & $\begin{array}{l}\text { GM2, Globo- } \\
\text { H, Lewis Y, Tn- } \\
\text { MUC1, Tn(c), } \\
\operatorname{sTN}(c), \operatorname{TF}(c)\end{array}$ & $\begin{array}{l}\text { Heptavalent KLH } \\
\text { conjugate }\end{array}$ \\
\hline $\begin{array}{l}\text { Sabbatini } \\
2012\end{array}$ & $\begin{array}{l}\text { Uncontrolled } \\
\text { phase I }\end{array}$ & 28 & $\begin{array}{l}\text { No evidence of disease after sec- } \\
\text { ond- or third-line therapy }\end{array}$ & NY-ESO-1 & Long peptides \\
\hline $\begin{array}{l}\text { Sabbatini } \\
2013\end{array}$ & $\mathrm{RCT}$ & 888 & $\begin{array}{l}\text { No evidence of disease after pri- } \\
\text { mary therapy }\end{array}$ & CA-125 & $\begin{array}{l}\text { Antibody vs place- } \\
\text { bo }\end{array}$ \\
\hline $\begin{array}{l}\text { Sabbatini } \\
2017\end{array}$ & $\mathrm{RCT}$ & 171 & $\begin{array}{l}\text { No evidence of disease after sec- } \\
\text { ond- or third-line therapy }\end{array}$ & $\begin{array}{l}\text { Globo-H, GM2, } \\
\text { MUC1-TN, TF }\end{array}$ & $\begin{array}{l}\text { Polyvalent anti- } \\
\text { gen-KLH vaccine }\end{array}$ \\
\hline $\begin{array}{l}\text { Sandmaier } \\
1999\end{array}$ & $\begin{array}{l}\text { Uncontrolled } \\
\text { phase II }\end{array}$ & 7 & Unknown & Sialyl-Tn & KLH conjugate \\
\hline Schultes 1998 & $\begin{array}{l}\text { Retrospective } \\
\text { uncontrolled }\end{array}$ & 75 & Unknown & CA-125 & Antibody \\
\hline Ströhlein 2009 & $\begin{array}{l}\text { Uncontrolled } \\
\text { phase I }\end{array}$ & 2 & Progressive disease & $\begin{array}{l}\text { EpCAM or } \\
\text { Her-2/Neu }\end{array}$ & $\begin{array}{l}\text { Trifunctional anti- } \\
\text { body }\end{array}$ \\
\hline
\end{tabular}


Table 2. Overview of included studies (Continued)

\begin{tabular}{|c|c|c|c|c|c|}
\hline Suzuki 2016 & $\begin{array}{l}\text { Uncontrolled } \\
\text { phase II }\end{array}$ & 32 & Unknown & $\begin{array}{l}\text { Glypican-3 } \\
\text { (GCP3) }\end{array}$ & Peptide vaccine \\
\hline Takeoka 2017 & $\begin{array}{l}\text { Uncontrolled } \\
\text { phase I }\end{array}$ & 2 & Advanced cancer & NY-ESO-1 & $\begin{array}{l}\text { Whole protein vac- } \\
\text { cine }\end{array}$ \\
\hline Takeuchi 2013 & $\begin{array}{l}\text { Uncontrolled } \\
\text { phase I/II }\end{array}$ & 38 & Unknown & $\begin{array}{l}\text { HLA-A24: } \\
\text { FOXM1, MELK, } \\
\text { HJURP, VEG- } \\
\text { FR1, VEGFR2; } \\
\text { HLA-A02: HIG2, } \\
\text { VEGFR1, VEG- } \\
\text { FR2 }\end{array}$ & Short peptides \\
\hline Tsuda 2004 & $\begin{array}{l}\text { Uncontrolled } \\
\text { phase I/II }\end{array}$ & 7 & (No) evidence of disease & $\begin{array}{l}\text { Patient-tailored } \\
\text { cocktail }\end{array}$ & $\begin{array}{l}\text { Multi-peptide vac- } \\
\text { cine }\end{array}$ \\
\hline $\begin{array}{l}\text { van Zan- } \\
\text { ten-Przybysz } \\
2002\end{array}$ & $\begin{array}{l}\text { Uncontrolled } \\
\text { phase I/II }\end{array}$ & 5 & $\begin{array}{l}\text { Residual or recurrent disease after } \\
\text { prior chemotherapy }\end{array}$ & $\begin{array}{l}\text { Membrane fo- } \\
\text { late receptor }\end{array}$ & Antibody \\
\hline Vermeij 2012 & $\begin{array}{l}\text { Uncontrolled } \\
\text { phase II }\end{array}$ & 12 & Recurrent disease & p53 & Long peptides \\
\hline Wagner 1993 & $\begin{array}{l}\text { Retrospective } \\
\text { uncontrolled }\end{array}$ & 58 & Unknown & CA-125 & Antibody \\
\hline
\end{tabular}

APC: Adenomatous polyposis coli.

CA-125: cancer antigen-125.

CDC2: Cell division control protein 2.

CEA: carcinoembryonic antigen.

ED: Evidence of disease.

EPCAM: epithelial cell adhesion molecule.

ERbB2: Human Epidermal growth factor Receptor 2.

FBP: Folate binding protein.

HLA: human leucocyte antigen.

hTERT: telomerase reverse transcriptase.

MAGE-A1: melanoma-associated antigen A1.

MUC1: Mucin-1.

NED: No evidence of disease.

NY-ESO-1: New York esophageal squamous cell carcinoma 1.

PADRE: DR-restricted Th helper epitope.

$\mathrm{RCT}$ : randomised controlled trial.

sTn: sialyl Tn.

TERT: Telomerase Reverse Transcriptase.

TF: Thompson Friedreich. 


\begin{tabular}{|c|c|c|c|c|c|c|c|c|c|c|c|c|}
\hline & $\mathbf{N}$ & $\begin{array}{l}\text { Clear } \\
\text { defini- } \\
\text { tion of } \\
\text { inclu- } \\
\text { sion/ex- } \\
\text { clusion } \\
\text { criteria }\end{array}$ & $\begin{array}{l}\text { Represen- } \\
\text { tative of } \\
\text { true pop- } \\
\text { ulation }\end{array}$ & $\begin{array}{l}\text { Baseline } \\
\text { charac- } \\
\text { teris- } \\
\text { tics ad- } \\
\text { equate- } \\
\text { ly de- } \\
\text { scribed }\end{array}$ & $\begin{array}{l}\text { Inter- } \\
\text { ven- } \\
\text { tions } \\
\text { clear- } \\
\text { ly de- } \\
\text { scribed }\end{array}$ & $\begin{array}{l}\text { Con- } \\
\text { comi- } \\
\text { tant/ } \\
\text { concur- } \\
\text { rent im- } \\
\text { munomod- } \\
\text { ulato- } \\
\text { ry treat- } \\
\text { ment }\end{array}$ & $\begin{array}{l}\text { Out- } \\
\text { come } \\
\text { mea- } \\
\text { sures } \\
\text { clearly } \\
\text { - speci- } \\
\text { fied }\end{array}$ & $\begin{array}{l}\text { Out- } \\
\text { come } \\
\text { mea- } \\
\text { sures } \\
\text { relevant }\end{array}$ & $\begin{array}{l}\text { Out- } \\
\text { come } \\
\text { mea- } \\
\text { sures } \\
\text { clearly } \\
\text { report- } \\
\text { ed }\end{array}$ & $\begin{array}{l}\text { Ade- } \\
\text { quate } \\
\text { ratio- } \\
\text { nale for } \\
\text { number } \\
\text { of pa- } \\
\text { tients }\end{array}$ & $\begin{array}{l}\text { Ade- } \\
\text { quate } \\
\text { descrip- } \\
\text { tion of } \\
\text { exclu- } \\
\text { sion / } \\
\text { with- } \\
\text { drawal }\end{array}$ & $\begin{array}{l}\text { Ade- } \\
\text { quate } \\
\text { presen- } \\
\text { tation of } \\
\text { results }\end{array}$ \\
\hline Antonilli 2016 & 10 & yes & unknown & yes & yes & no & yes & yes & yes & no & no & yes \\
\hline Berinstein 2012 & 6 & no & unknown & yes & yes & $\begin{array}{l}\text { un- } \\
\text { known }\end{array}$ & yes & yes & yes & no & no & yes \\
\hline Berinstein 2013 & 19 & yes $^{a}$ & unknown & no & yes $^{a}$ & yes & no & yes & no & no & no & no \\
\hline Brossart 2000 & 3 & yes & unknown & no & yes & $\begin{array}{l}\text { un- } \\
\text { known }\end{array}$ & yes & yes & yes & no & no & no \\
\hline Chianese-Bullock 2008 & 9 & yes & no & yes & yes & $\begin{array}{l}\text { un- } \\
\text { known }\end{array}$ & yes & yes & yes & no & yes & no \\
\hline Dhodapkar 2012 & 6 & no & unknown & no & no & $\begin{array}{l}\text { un- } \\
\text { known }\end{array}$ & no & yes & no & $\begin{array}{l}\text { un- } \\
\text { known }\end{array}$ & no & no \\
\hline Diefenbach 2008 & 9 & yes & no & yes & yes & no & yes & yes & yes & no & yes & yes \\
\hline Dijkgraaf 2015 & 6 & yes & no & yes & yes & yes & yes & yes & yes & no & yes & yes \\
\hline Ehlen 2005 & 13 & yes & yes & yes & yes & $\begin{array}{l}\text { un- } \\
\text { known }\end{array}$ & yes & yes & yes & no & yes & yes \\
\hline Galanis 2010 & 21 & yes & unknown & no & yes & no & yes & yes & yes & no & yes & yes \\
\hline Goh 2013 & 63 & yes $^{a}$ & unknown & no & no & no & no & yes & no & no & no & no \\
\hline Gribben 2005 & 6 & no & no & no & yes & $\begin{array}{l}\text { un- } \\
\text { known }\end{array}$ & no & yes & no & yes & yes & no \\
\hline Gulley 2008 & 3 & yes & unknown & no & yes & $\begin{array}{l}\text { un- } \\
\text { known }\end{array}$ & yes & yes & yes & no & yes & no \\
\hline
\end{tabular}




\begin{tabular}{|c|c|c|c|c|c|c|c|c|c|c|c|c|}
\hline Imhof 2013 & 15 & yes $^{a}$ & unknown & no & yes & no & no & yes & no & no & no & no \\
\hline Kaumaya 2009 & 5 & no & no & no & yes & no & yes & yes & yes & no & no & no \\
\hline Kawano 2014 & 42 & yes & no & yes & yes & yes & yes & yes & yes & no & no & yes \\
\hline Kobayashi 2014 & 56 & yes & unknown & yes & yes & no & no & yes & no & no & yes & no \\
\hline Le 2012 & 2 & yes & no & no & yes & no & yes & yes & yes & no & no & no \\
\hline Leffers 2009a & 20 & yes & unknown & yes & yes & no & yes & yes & yes & yes & yes & yes \\
\hline Letsch 2011 & 8 & $\begin{array}{l}\text { un- } \\
\text { known }\end{array}$ & unknown & no & yes & $\begin{array}{l}\text { un- } \\
\text { known }\end{array}$ & $\begin{array}{l}\text { un- } \\
\text { known }\end{array}$ & $\begin{array}{l}\text { un- } \\
\text { known }\end{array}$ & $\begin{array}{l}\text { un- } \\
\text { known }\end{array}$ & $\begin{array}{l}\text { un- } \\
\text { known }\end{array}$ & $\begin{array}{l}\text { un- } \\
\text { known }\end{array}$ & $\begin{array}{l}\text { un- } \\
\text { known }\end{array}$ \\
\hline Ma 2002 & 4 & no & unknown & no & no & $\begin{array}{l}\text { un- } \\
\text { known }\end{array}$ & no & no & no & no & no & no \\
\hline MacLean 1992 & 10 & no & unknown & no & yes & yes & yes & yes & yes & no & no & yes \\
\hline MacLean 1996 & 34 & yes & unknown & no & yes & yes & no & yes & no & no & yes & no \\
\hline Möbus 2003 & 44 & yes & yes & yes & yes & yes & no & yes & yes & no & no & yes \\
\hline Mohebtash 2011 & 14 & yes & unknown & no & yes & no & yes & yes & yes & no & no & no \\
\hline Morse 2011 & 8 & yes & no & no & yes & $\begin{array}{l}\text { un- } \\
\text { known }\end{array}$ & yes & yes & no & no & yes & no \\
\hline Nicholson 2004 & 26 & yes & unknown & no & yes & $\begin{array}{l}\text { un- } \\
\text { known }\end{array}$ & yes & yes & yes & no & yes & yes \\
\hline Nishikawa 2006 & 4 & no & unknown & no & no & $\begin{array}{l}\text { un- } \\
\text { known }\end{array}$ & yes & yes & yes & no & no & no \\
\hline Noujaim 2001 & 184 & yes & yes & yes & no & $\begin{array}{l}\text { un- } \\
\text { known }\end{array}$ & yes & yes & yes & no & no & yes \\
\hline O'Cearbhaill 2016 & 24 & yes & yes & yes & yes & no & no & yes & no & no & no & no \\
\hline Odunsi 2007 & 18 & no & no & yes & yes & $\begin{array}{l}\text { un- } \\
\text { known }\end{array}$ & no & yes & yes & no & $\begin{array}{l}\text { un- } \\
\text { known }\end{array}$ & yes \\
\hline
\end{tabular}




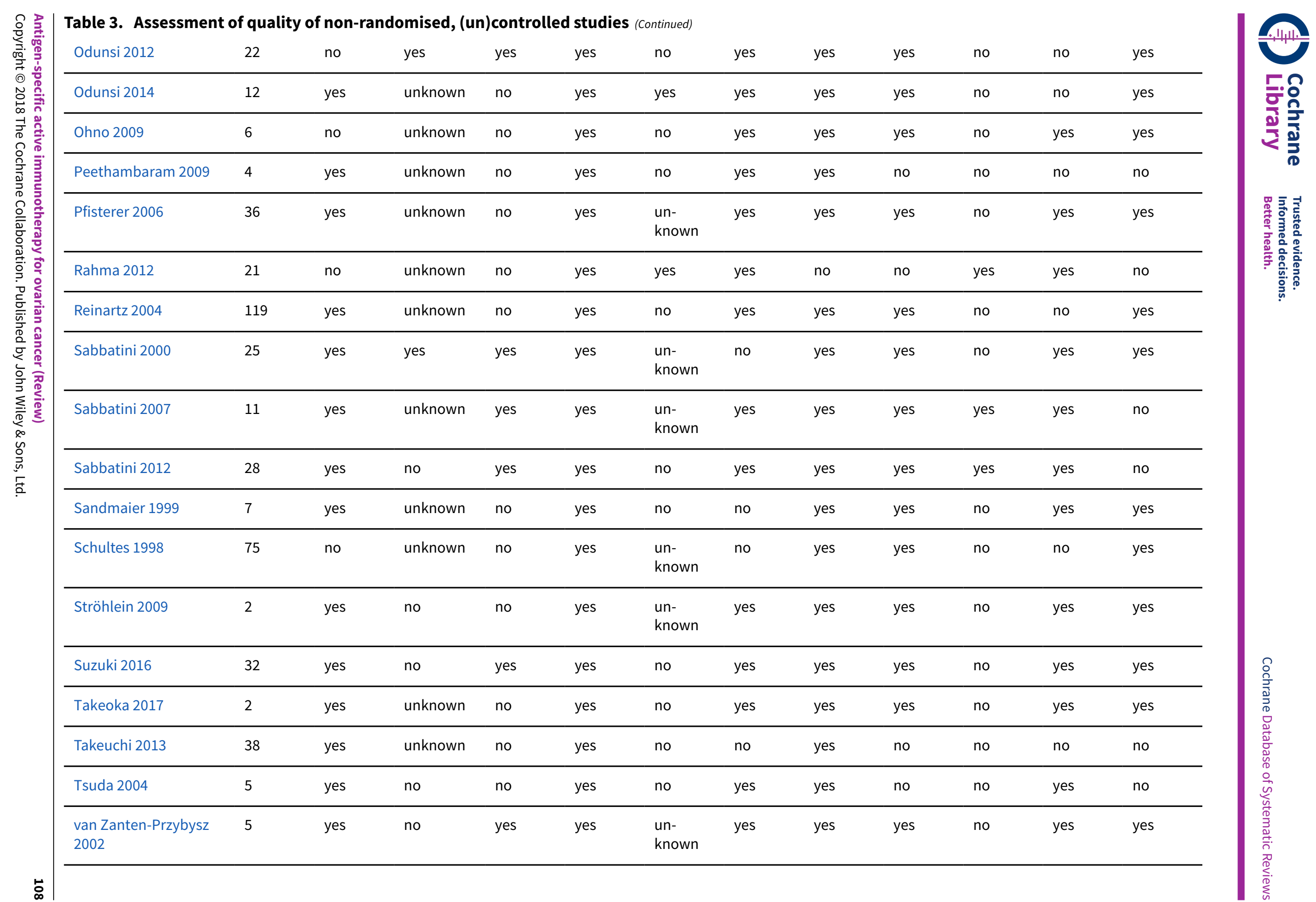




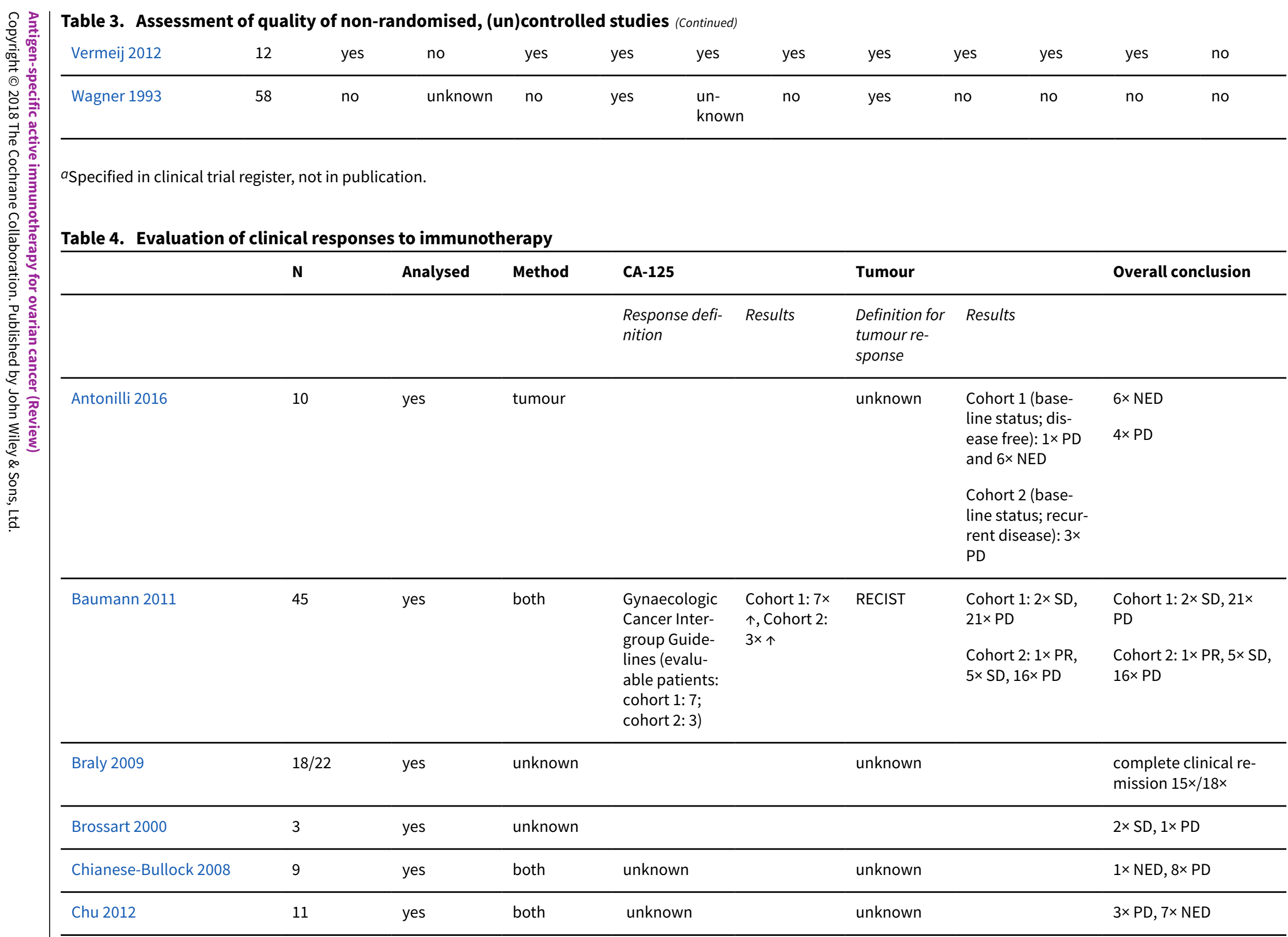




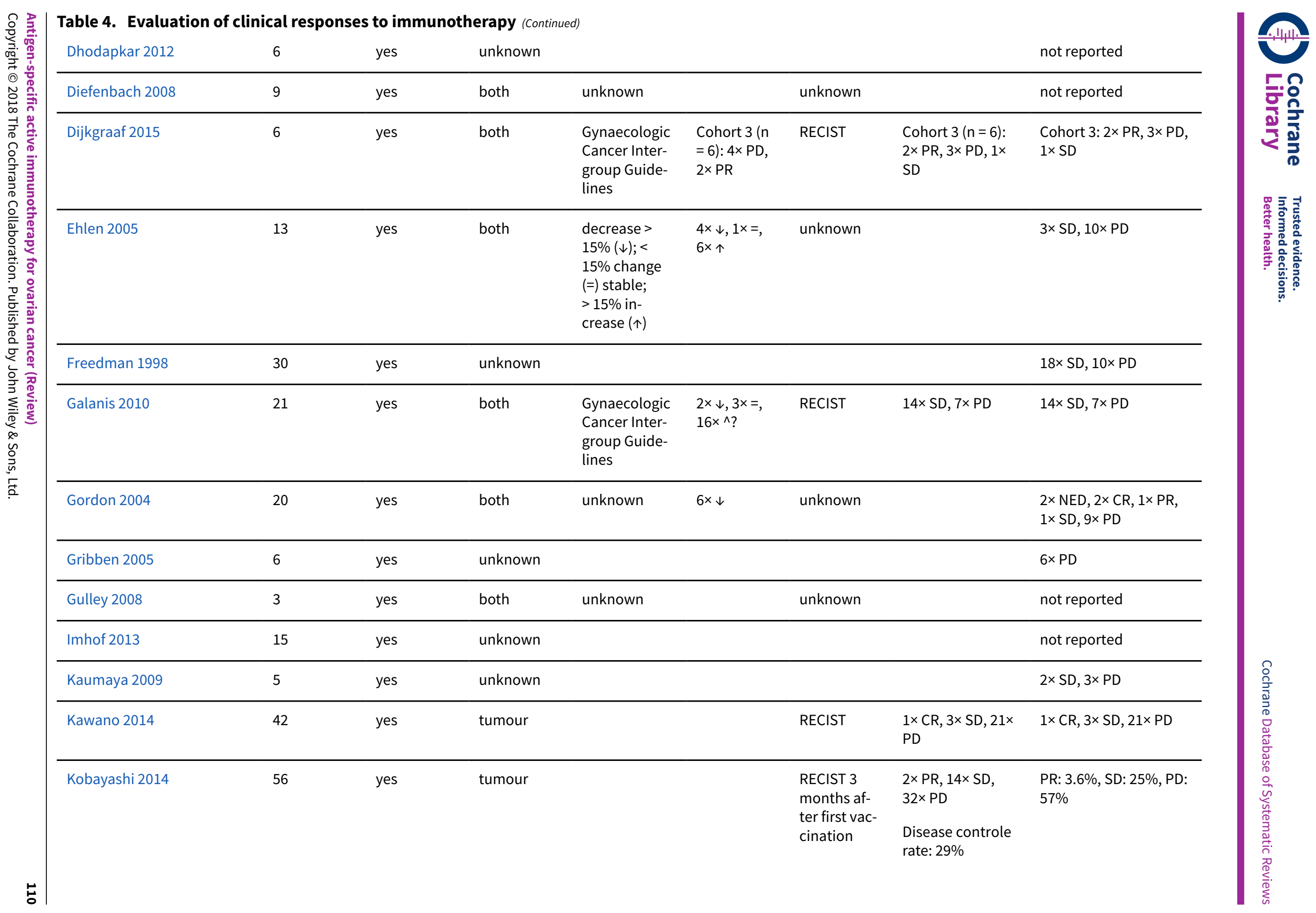




\begin{tabular}{|c|c|c|c|c|c|c|c|c|}
\hline & & & & & & & $\begin{array}{l}\text { Objective re- } \\
\text { sponse rate: } 3.6 \%\end{array}$ & \\
\hline Le 2012 & 2 & yes & tumour & & & RECIST & $2 \times P D$ & $2 \times P D$ \\
\hline Leffers 2009a & 20 & yes & both & $\begin{array}{l}\text { Gynaecologic } \\
\text { Cancer Inter- } \\
\text { group Guide- } \\
\text { lines }\end{array}$ & not reported & RECIST & not reported & $2 \times \mathrm{SD}, 18 \times \mathrm{PD}$ \\
\hline Lennerz 2014 & 7 & yes & tumour & & & RECIST & $5 \times \mathrm{PD}, 2 \times \mathrm{NE}$ & $5 \times P D$ \\
\hline Letsch 2011 & 8 & yes & unknown & & & & & $4 \times \mathrm{SD}, 4 \times \mathrm{PD}$ \\
\hline MacLean 1992 & 10 & yes & unknown & & & & & $3 \times \mathrm{SD}, 7 \times \mathrm{PD}$ \\
\hline Method 2002 & 102 & yes & unknown & & & & & not reported \\
\hline Mohebtash 2011 & 14 & yes & unknown & & & & & $1 \times \mathrm{SD}, 11 \times \mathrm{PD}$ \\
\hline Nicholson 2004 & 26 & yes & CA- 125 & unknown & & & & $\begin{array}{l}21 \times \mathrm{PD}, 1 \times \mathrm{SD}, 1 \times \text { lost } \\
\text { to follow-up, } 3 \times \text { un- } \\
\text { known }\end{array}$ \\
\hline Odunsi 2007 & 18 & yes & tumour & & & unknown & & $1 \times \mathrm{CR}, 17 \times$ unknown \\
\hline Odunsi 2014 & 12 & yes & tumour & & & RECIST & $1 \times \mathrm{PD}, 5 \times \mathrm{SD}$ & PD: $10 \%$, SD:50\% \\
\hline Ohno 2009 & 6 & yes & both & unknown & not reported & RECIST & $1 \times \mathrm{SD}, 3 \times \mathrm{PD}$ & $\begin{array}{l}1 \times \mathrm{SD}, 4 \times \mathrm{PD}, 1 \times \text { with } \\
\text { drawal }\end{array}$ \\
\hline Peethambaram 2009 & 4 & yes & tumour & & & unknown & $2 \times \mathrm{SD}, 2 \times \mathrm{PD}$ & $2 \times \mathrm{SD}, 2 \times \mathrm{PD}$ \\
\hline Rahma 2012 & 21 & yes & both & unknown & not reported & RECIST & $\begin{array}{l}\text { Cohort 1: } 2 \times \text { NED, } \\
11 \times \text { PD }\end{array}$ & $\begin{array}{l}\text { Cohort 1: } 2 \times \text { NED, } 11 \times \\
\text { PD }\end{array}$ \\
\hline & & & & & & & $\begin{array}{l}\text { Cohort 2: 2× NED, } \\
5 \times \text { PD }\end{array}$ & $\begin{array}{l}\text { Cohort 2: } 2 \times \text { NED, } 5 \times \\
\text { PD }\end{array}$ \\
\hline Reinartz 2004 & 119 & yes & tumour & & & WHO & & not reported \\
\hline Sabbatini 2006 & 42 & yes & both & unknown & & unknown & & $\begin{array}{l}12 \times \mathrm{SD}, 21 \times \mathrm{PD}, 9 \times \\
\text { withdrawal }(6 \times \mathrm{PD})\end{array}$ \\
\hline
\end{tabular}




\begin{tabular}{|c|c|c|c|c|c|c|c|c|}
\hline Sabbatini 2012 & 28 & yes & tumour & & & RECIST & $\begin{array}{l}\text { Cohort 1: 1× NED, } \\
3 \times \text { PD } \\
\text { Cohort 2: } 3 \times \text { NED, } \\
\text { 10× PD } \\
\text { Cohort 3: } 2 \times \text { NED, } \\
9 \times \text { PD }\end{array}$ & $\begin{array}{l}\text { Cohort 1: } 1 \times \text { NED, } 3 \times \\
\text { PD } \\
\text { Cohort 2: } 3 \times \text { NED, 10× } \\
\text { PD } \\
\text { Cohort 3: } 2 \times \text { NED, } 9 \times \\
\text { PD }\end{array}$ \\
\hline Ströhlein 2009 & 2 & yes & both & unknown & & unknown & & $1 \times \mathrm{PD}, 1 \times \mathrm{PR}$ or $\mathrm{SD}$ \\
\hline Suzuki 2016 & 32 & yes & tumour & & & RECIST & $\begin{array}{l}12 \text { months: PR: } \\
2 / 32 \text {, PD: } 28 / 32\end{array}$ & $2 \times \mathrm{PR}, 28 \times \mathrm{PD}$ \\
\hline Takeoka 2017 & 2 & yes & tumour & & & RECIST & $2 \times P D$ & $2 \times P D$ \\
\hline Takeuchi 2013 & 38 & yes & tumour & & & RECIST & $\begin{array}{l}1 \times C R, 2 \times P R, 10 \times \\
S D, 9 \times P D\end{array}$ & $\begin{array}{l}1 \times \mathrm{CR}, 2 \times \mathrm{PR}, 10 \times \mathrm{SD} \\
9 \times \mathrm{PD}\end{array}$ \\
\hline Tsuda 2004 & 5 & yes & both & unknown & & WHO & & $4 \times \mathrm{PD}, 1 \times \mathrm{SD}$ \\
\hline van Zanten-Przybysz 2002 & 5 & yes & both & unknown & $\begin{array}{l}1 \times \downarrow, 1 \times= \\
1 \times \uparrow, 2 \times \text { un- } \\
\text { known }\end{array}$ & unknown & $\begin{array}{l}1 \times \mathrm{NED}, 1 \times \mathrm{SD}, 2 \times \\
\mathrm{PD}, 1 \times \text { unknown }\end{array}$ & $3 \times P D, 2 \times S D$ \\
\hline Vermeij 2012 & 12 & yes & both & $\begin{array}{l}\text { Gynaecologic } \\
\text { Cancer Inter- } \\
\text { group Guide- } \\
\text { lines }\end{array}$ & $7 \times \downarrow /=, 3 \times \uparrow$ & RECIST & not reported & $2 \times \mathrm{SD}, 8 \times \mathrm{PD}$ \\
\hline Wagner 1993 & 58 & yes & CA-125 & unknown & & & & not reported \\
\hline Berek 2001 & 252 & no & & & & & & \\
\hline Berek 2004 & 145 & no & & & & & & \\
\hline Berek 2009 & 371 & no & & & & & & \\
\hline Berinstein 2012 & 6 & no & & & & & & \\
\hline Berinstein 2013 & 19 & no & & & & & & \\
\hline Buzzonetti 2014 & 129 & no & & & & & & \\
\hline
\end{tabular}




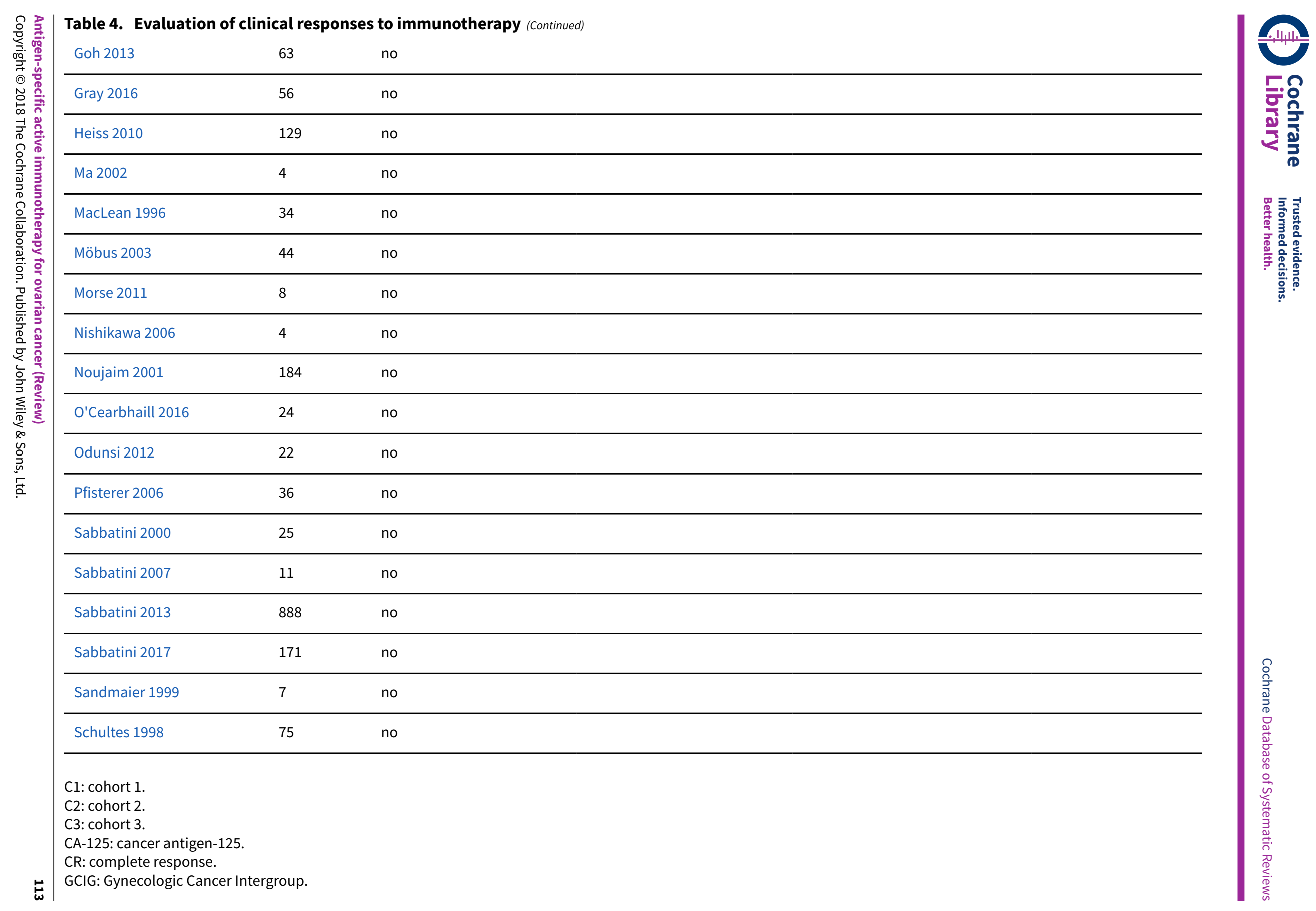



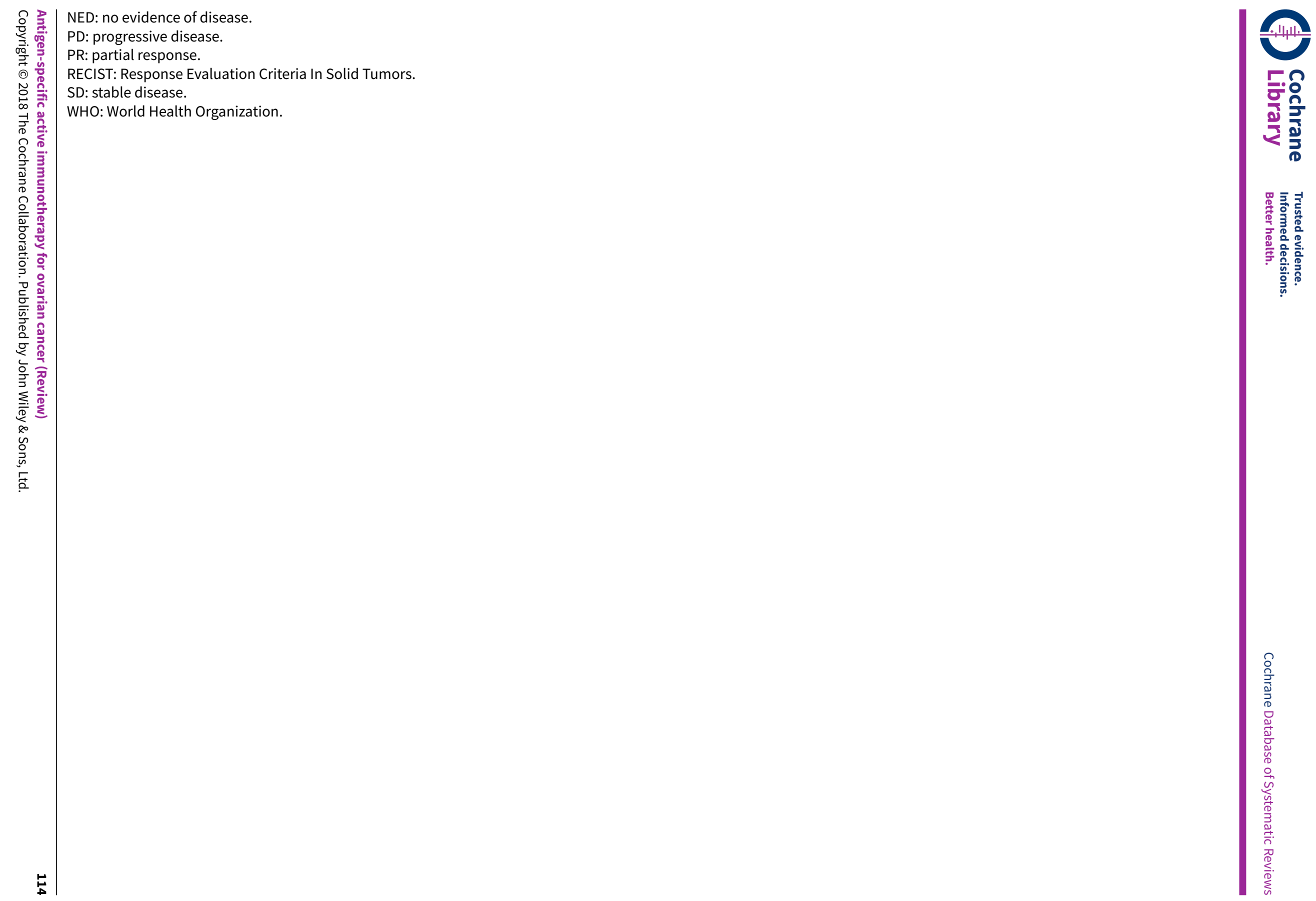
Table 5. Definitions and results of survival and/or relapse analysis in antigen-specific antibody studies

\begin{tabular}{llll}
\hline Study & Analysed & Definition & Results \\
\hline Baumann 2011 & yes & $\begin{array}{l}\text { progression-free sur- } \\
\text { vival/overall survival }\end{array}$ & $\begin{array}{l}\text { median progression-free survival: low dose } 70 \text { days (95\% Cl 63 } \\
\text { to 91), high dose } 68 \text { days (95\% Cl } 58 \text { to } 77)\end{array}$ \\
& & $\begin{array}{l}\text { median overall survival: low dose } 137 \text { days (95\% Cl 99 to 218), } \\
\text { high dose } 185 \text { days (95\% Cl 134 to 472) }\end{array}$
\end{tabular}

\begin{tabular}{lll}
\hline Berek 2001 yes & time to relapse & $\begin{array}{l}\text { median time to relapse: placebo 11.3, robust HAMA 16.4, ro- } \\
\text { bust Ab2 18.9 months }\end{array}$ \\
\hline Berek 2004 yes & time to relapse & $\begin{array}{l}\text { all patients: time to relapse: oregovomab 13.3 vs placebo 10.3 } \\
\text { months ( }=0.71)(\mathrm{HR} 0.881,95 \% \mathrm{Cl} 0.578 \text { to } 1.349)\end{array}$ \\
& $\begin{array}{l}\text { successful front-line therapy patients: time to relapse: oregov- } \\
\text { omab 24 vs placebo } 10.8 \text { months }(\mathrm{P}=0.71)(\mathrm{HR} 0.543,95 \% \mathrm{Cl} \\
0.287 \text { to } 1.025)\end{array}$ \\
& & \\
\hline
\end{tabular}

\begin{tabular}{llll}
\hline Berek 2009 yes & $\begin{array}{l}\text { time to relapse (ran- } \\
\text { domisation to re- } \\
\text { lapse) }\end{array}$ & $\begin{array}{l}\text { median time to relapse: oregovomab 10.3 months (95\% Cl 9.7 } \\
\text { to } 13.0 \text { months) vs placebo 12.9 months (95\% Cl 10.1 to 17.4 } \\
\text { months) }(\mathrm{P}=.29)\end{array}$ \\
\hline
\end{tabular}

\begin{tabular}{lll}
\hline Braly 2009 yes & $\begin{array}{l}\text { progression-free sur- } \\
\text { vival }\end{array}$ & $\begin{array}{l}\text { median progression-free survival: simultaneous administra- } \\
\text { tion } 17.9 \text { months vs delayed administration } 16.1 \text { months }\end{array}$ \\
\hline
\end{tabular}

\begin{tabular}{|c|c|c|c|}
\hline Buzzonetti 2014 & no & & \\
\hline Ehlen 2005 & yes & $\begin{array}{l}\text { time to progres- } \\
\text { sion/survival (first } \\
\text { dose to death) }\end{array}$ & $\begin{array}{l}\text { time to progression: median } 8.4 \text { weeks (range } 2 \text { to } 61 \text { weeks); } \\
\text { survival } 37 \text { weeks (range } 11 \text { to } 110 \text { ) }\end{array}$ \\
\hline Gordon 2004 & yes & $\begin{array}{l}\text { time to progres- } \\
\text { sion/survival (first } \\
\text { dose to death) }\end{array}$ & $\begin{array}{l}\text { time to progression: median } 11 \text { weeks (T-cell responders vs } \\
\text { non-responders; } \mathrm{P}<0.0001 ; \mathrm{HR} 0.150,95 \% \mathrm{Cl} 0.006 \text { to } 0.168 \text { ); } \\
\text { survival: median } 70.4 \text { weeks (T-cell responders vs non-respon- } \\
\text { ders; } \mathrm{P}<0.002 ; \mathrm{HR} 0.157,95 \% \mathrm{Cl} 0.009 \text { to } 0.347 \text { ) }\end{array}$ \\
\hline Heiss 2010 & yes & $\begin{array}{l}\text { puncture-free sur- } \\
\text { vival (first dose to } \\
\text { therapeutic punc- } \\
\text { ture or death)/over- } \\
\text { all survival (first dose } \\
\text { to death) }\end{array}$ & $\begin{array}{l}\text { Median puncture-free survival: paclitaxel + catumaxomab } 52 \\
\text { days ( } 95 \% \mathrm{Cl} 38 \text { to } 62 \text { ) vs catumaxomab } 11 \text { days ( } 95 \% \mathrm{Cl} 9 \text { to } \\
\text { 20) } \\
\text { Median overall survival: paclitaxel + catumaxomab } 110 \text { days } \\
\text { ( } 95 \% \mathrm{Cl} 70 \text { to } 164 \text { ) vs catumaxomab } 81 \text { days ( } 95 \% \mathrm{Cl} 68 \text { to } 134 \text { ) }\end{array}$ \\
\hline
\end{tabular}

\begin{tabular}{llll}
\hline Ma 2002 & no & \\
\hline Method 2002 & no & \\
\hline Möbus 2003 yes & survival (first dose to & $\begin{array}{l}\text { survival: median } 16.8 \text { months (95\% Cl 10.3 to 22.6) (Ab3 re- } \\
\text { sponders vs non-responders 18.2 vs 13.1, P = 0.0896; HAMA re- } \\
\text { sponders vs non-responders 22.6 months vs 7.6 months, } \mathrm{P}= \\
\text { vival (diagnosis to } \\
\text { death) }\end{array}$ & \begin{tabular}{l} 
0.0016); overall survival: median 34.4 months \\
\hline
\end{tabular} \\
\hline
\end{tabular}

\begin{tabular}{llll}
\hline Nicholson 2004 & no & \\
\hline Noujaim 2001 & yes & $\begin{array}{l}\text { survival (first dose to } \\
\text { death) }\end{array}$ & $\begin{array}{l}\text { median survival and 3-year survival: Ab3 responders vs non- } \\
\text { responders 22.9 vs 13.5 months, } \mathrm{P}=0.0089,38 \% \text { vs } 8 \% ; \text {-cell }\end{array}$
\end{tabular}


Table 5. Definitions and results of survival and/or relapse analysis in antigen-specific antibody studies (Continued) responders vs non-responders $(n=16)>84$ vs 13.2 months, $P$ $=0.0202,75 \%$ vs $0 \%$

\begin{tabular}{|c|c|c|c|}
\hline Pfisterer 2006 & no & & \\
\hline Reinartz 2004 & yes & $\begin{array}{l}\text { survival (first dose to } \\
\text { death) }\end{array}$ & $\begin{array}{l}\text { median survival: } 19.4 \text { months, } \mathrm{Ab} 3 \text { responders vs non-respon- } \\
\text { ders: } 23.4 \text { vs } 4.9 \text { months, } \mathrm{P}<0.0001\end{array}$ \\
\hline Sabbatini 2006 & yes & time to progression & time to progression: 4 months ( $95 \% \mathrm{Cl} 3$ to 5 months) \\
\hline Sabbatini 2013 & yes & $\begin{array}{l}\text { recurrence-free sur- } \\
\text { vival (randomisation } \\
\text { to recurrence)/over- } \\
\text { all survival (randomi- } \\
\text { sation to death) }\end{array}$ & $\begin{array}{l}\text { median recurrence-free survival: abagovomab } 403 \text { days ( } 95 \% \\
\mathrm{Cl} 323 \text { to } 414 \text { ) vs placebo } 402 \text { days ( } 95 \% \mathrm{Cl} 323 \text { to } 487 \text { ) } \\
\text { 2-year overall survival rate: abagovomab } 80 \% \text { (SE } 1.71 \text { ) vs } \\
\text { placebo } 80 \% \text { (SE 2.43) }\end{array}$ \\
\hline Schultes 1998 & yes & $\begin{array}{l}\text { overall survival (diag- } \\
\text { nosis to death) }\end{array}$ & $\begin{array}{l}\text { median overall survival: robust } A b 3 \text { responders vs non-robust } \\
\text { responders } 49 \text { vs } 38 \text { months, } P=0.0029 ; A b 2 \text { robust vs non-ro- } \\
\text { bust responders } 30.0 \text { vs } 44.0 \text { months, } P=0.0475\end{array}$ \\
\hline Ströhlein 2009 & yes & overall survival & not described separately for ovarian cancer patients \\
\hline $\begin{array}{l}\text { van Zanten-Przy- } \\
\text { bysz } 2002\end{array}$ & yes & $\begin{array}{l}\text { survival (first dose to } \\
\text { death) }\end{array}$ & median survival: 22.0 months \\
\hline Wagner 1993 & yes & not described & survival: robust Ab2 vs non-robust Ab2 responders: NS \\
\hline
\end{tabular}

Ab2: anti-idiotype antibody.

Ab3: anti-anti-idiotype antibody.

$\mathrm{Cl}$ : confidence interval.

HAMA: human-anti-mouse antibody.

HR: hazard ratio.

SE: standard error.

Table 6. Definitions and results of survival and/or relapse analysis in other antigen-specific immunotherapy studies

\begin{tabular}{llll}
\hline Study & Analysed & Definition & Results \\
\hline Antonilli 2016 & yes & recurrence rate & recurrence rate: $\mathrm{n}=2$ \\
\hline Berinstein 2012 & yes & $\begin{array}{l}\text { time to progression (study day 0 to } \\
\text { relapse) }\end{array}$ & $\begin{array}{l}\text { median time to progression }>8 \text { months (range 4 } \\
\text { to }>9)\end{array}$ \\
\hline
\end{tabular}

\begin{tabular}{|c|c|c|c|}
\hline Berinstein 2013 & no & & \\
\hline Brossart 2000 & no & & \\
\hline $\begin{array}{l}\text { Chianese-Bullock } \\
2008\end{array}$ & no & & \\
\hline Chu 2012 & yes & $\begin{array}{l}\text { progression-free survival (first vac- } \\
\text { cination to relapse)/overall sur- } \\
\text { vival (first vaccination to death/ } \\
\text { last follow-up) }\end{array}$ & $\begin{array}{l}\text { 3-year progression-free survival: arm } 1 \text { vs arm } 2 \text {, } \\
40 \% \text { vs } 80 \%(P=0.17) \\
\text { 3-year overall survival: arm } 1 \text { vs arm } 2,80 \% \text { vs } \\
100 \%(P=1.00)\end{array}$ \\
\hline
\end{tabular}


Table 6. Definitions and results of survival and/or relapse analysis in other antigen-specific immunotherapy

studies (continued) yes

Dijkgraaf $2015 \quad$ yes

time to progression (last chemo to relapse)

progression-free survival: time from start of therapy until progression in weeks

overall survival: time from start of therapy until death in weeks median time to progression 13.0 months $(95 \% \mathrm{Cl}$ 11.2 to not reached)

Progression-free survival cohort 3: 8 to 36 (median 13)

Overall survival cohort 3: 12 to 48 (median 37)

\begin{tabular}{|c|c|c|c|}
\hline Dhodapkar 2012 & no & & \\
\hline Freedman 1998 & yes & progression-free interval; survival & $\begin{array}{l}\text { median progression-free interval: } 4 \text { months } \\
(95 \% \mathrm{Cl} 1.9 \text { to } 7.6) \\
\text { median survival: } 13.3 \text {. months }(95 \% \mathrm{Cl} 1.5 \text { to } \\
30.8)\end{array}$ \\
\hline Galanis 2010 & yes & overall survival & $\begin{array}{l}\text { median overall survival: } 12.2 \text { months (range } 1.3 \\
\text { to } 38.4 \text { ) }\end{array}$ \\
\hline Goh 2013 & yes & $\begin{array}{l}\text { progression-free survival; overall } \\
\text { survival }\end{array}$ & $\begin{array}{l}\text { median progression-free survival vaccine vs } \\
\text { standard of care } 365 \text { days vs } 321 \text { days } \\
\text { overall survival: not reported }\end{array}$ \\
\hline Gray 2016 & yes & $\begin{array}{l}\text { progression-free survival } \\
\text { overall survival }\end{array}$ & $\begin{array}{l}\text { progression-free survival: } 13 \text { months (Cvac) vs } 9 \\
\text { months (standard of care) } \\
\text { overall survival: median not reached at } 43 \\
\text { months in both study arms. }\end{array}$ \\
\hline
\end{tabular}

Gribben 2005

\begin{tabular}{llll}
\hline Gulley 2008 & yes & $\begin{array}{l}\text { progression-free survival; overall } \\
\text { survival }\end{array}$ & $\begin{array}{l}\text { progression-free survival: 9, 18, 19+ months; OS: } \\
6,19+, 21 \text { months }\end{array}$ \\
\hline Imhof 2013 & yes & $\begin{array}{l}\text { time to progression (first vaccina- } \\
\text { tion to relapse)/overall survival } \\
\text { (first vaccination to death) }\end{array}$ & not reported \\
\hline
\end{tabular}

\begin{tabular}{|c|c|c|c|}
\hline Kaumaya 2009 & no & & \\
\hline \multirow[t]{3}{*}{ Kawano 2014} & yes & median survival time & $\begin{array}{l}\text { median survival time overall }(n=42): 19.1 \\
\text { months }\end{array}$ \\
\hline & & & $\begin{array}{l}\text { median survival time platinum-sensitive }(n=17) \text { : } \\
39.3 \text { months }\end{array}$ \\
\hline & & & $\begin{array}{l}\text { median survival time platinum-resistant }(n=25) \text { : } \\
16.2 \text { months }\end{array}$ \\
\hline Kobayashi 2014 & yes & $\begin{array}{l}\text { median survival time from first } \\
\text { vaccination }\end{array}$ & median survival time 14.5 months \\
\hline Le 2012 & no & & \\
\hline Leffers 2009a & yes & $\begin{array}{l}\text { disease-specific survival (diagnosis } \\
\text { to death of ovarian cancer) }\end{array}$ & $\begin{array}{l}\text { median disease-specific survival participants vs } \\
\text { historical controls: } 44.0 \text { months vs } 47.4 \text { months }\end{array}$ \\
\hline
\end{tabular}


Table 6. Definitions and results of survival and/or relapse analysis in other antigen-specific immunotherapy studies (Lentinued)

no

\begin{tabular}{|c|c|c|c|}
\hline Letsch 2011 & no & & \\
\hline MacLean 1996 & yes & survival (trial entry to death) & median survival: 12.7 months \\
\hline MacLean 1992 & no & & \\
\hline \multirow[t]{2}{*}{ Mohebtash 2011} & yes & $\begin{array}{l}\text { progression-free survival/overall } \\
\text { survival }\end{array}$ & $\begin{array}{l}\text { median progression-free survival: } 2 \text { months } \\
\text { (range } 1 \text { to } 36 \text { ) }\end{array}$ \\
\hline & & & $\begin{array}{l}\text { median overall survival: } 15.5 \text { months (range } 1.5 \\
\text { to }>57.0 \text { ) }\end{array}$ \\
\hline Morse 2011 & yes & overall survival & $\begin{array}{l}\text { median overall survival: not reached (range } 289 \\
\text { to } 1115+\text { days) }\end{array}$ \\
\hline Nishikawa 2006 & no & & \\
\hline O'Cearbhaill 2016 & yes & $\begin{array}{l}\text { progression-free survival: } \\
\text { time from the end of adjuvant } \\
\text { chemotherapy until disease pro- } \\
\text { gression }\end{array}$ & not adequately described \\
\hline Odunsi 2007 & yes & $\begin{array}{l}\text { time to progression (first vaccina- } \\
\text { tion to relapse) }\end{array}$ & $\begin{array}{l}\text { median time to progression: } 19.0 \text { months (95\% } \\
\mathrm{Cl} 9.0 \text { to not reached) }\end{array}$ \\
\hline Odunsi 2012 & yes & $\begin{array}{l}\text { progression-free survival/overall } \\
\text { survival }\end{array}$ & $\begin{array}{l}\text { median progression-free survival: } 21 \text { months } \\
\text { ( } 95 \% \mathrm{Cl} 16 \text { to } 29 \text { months) }\end{array}$ \\
\hline & & & $\begin{array}{l}\text { median overall survival: } 48 \text { months }(95 \% \mathrm{CI} \text { not } \\
\text { estimable) }\end{array}$ \\
\hline
\end{tabular}

\begin{tabular}{|c|c|c|c|}
\hline Odunsi 2014 & no & & \\
\hline Ohno 2009 & no & & \\
\hline $\begin{array}{l}\text { Peethambaram } \\
2009\end{array}$ & yes & time to progression & $\begin{array}{l}\text { median time to progression: } 14.0 \text { (range } 12.1 \text { to } \\
18.3 \text { ) }\end{array}$ \\
\hline \multirow[t]{2}{*}{ Rahma 2012} & yes & $\begin{array}{l}\text { progression-free survival (date on } \\
\text { study to date of progression) }\end{array}$ & $\begin{array}{l}\text { median progression-free survival: } 4.2 \text { vs } 8.7 \\
\text { months }\end{array}$ \\
\hline & & $\begin{array}{l}\text { overall survival (date on study to } \\
\text { date of death or last follow-up) }\end{array}$ & median overall survival: 40.8 vs 29.6 months \\
\hline Sabbatini 2000 & yes & $\begin{array}{l}\text { time to progression (trial entry to } \\
\text { relapse) }\end{array}$ & $\begin{array}{l}\text { median time to progression: } 6 \text { months (range } 2 \\
\text { to } 17 \text { ) }\end{array}$ \\
\hline Sabbatini 2007 & yes & $\begin{array}{l}\text { time to progression (first vaccina- } \\
\text { tion to relapse) }\end{array}$ & $\begin{array}{l}\text { median time to progression: } 4.2 \text { months }(95 \% \mathrm{Cl} \\
2.7 \text { to } 8.5 \text { ) }\end{array}$ \\
\hline Sabbatini 2012 & yes & time to progression & $\begin{array}{l}\text { no differences between cohorts (numbers not } \\
\text { reported) }\end{array}$ \\
\hline Sabbatini 2017 & yes & $\begin{array}{l}\text { progression-free survival: time } \\
\text { from randomisation to first clini- } \\
\text { cal, biochemical, or radiological } \\
\text { evidence of progression }\end{array}$ & $\begin{array}{l}\text { progression-free survival: } 5.9 \text { months vaccine }+ \\
\text { OPT- } 821 \text { vs } 6.5 \text { months OPT- } 821 \text { only }\end{array}$ \\
\hline
\end{tabular}


Table 6. Definitions and results of survival and/or relapse analysis in other antigen-specific immunotherapy studies (Continued) overall survival: time from study untill death. overall survival: 46.5 months vaccine + OPT-821 vs 46.2 months OPT- 821 only

\begin{tabular}{llll}
\hline Sandmaier 1999 & no & \\
\hline Suzuki 2016 & yes & $\begin{array}{l}\text { time to progression/overall sur- } \\
\text { vival }\end{array}$ & $\begin{array}{l}\text { time of progression: not reported } \\
\text { overall survival after } 12 \text { months of all patients: } \\
20.6 \%\end{array}$ \\
\hline Takeoka 2017 & no & & \\
\hline Takeuchi 2013 & yes & overall survival & median overall survival: HLA-A24 5 months \\
& & & 54 to 921 days) \\
\hline Tsuda 2004 & no & \\
\hline Vermeij 2012 & no & \\
\hline
\end{tabular}

$\mathrm{Cl}$ : confidence interval. 


\begin{tabular}{|c|c|c|c|c|c|c|c|c|}
\hline Study & $\mathbf{N}$ & Dose & Target antigen & Analysed & Positive if: & $\%$ positive & Robust if: & $\%$ robust \\
\hline Baumann 2011 & 45 & $\mathrm{C} 1: 10-10-10-10 \mu \mathrm{g}$ & EpCAM & no & & & & \\
\hline & & C2: $10-20-50-100 \mathrm{~g}$ & & & & & & \\
\hline Berek 2001 & 252 & $2 \mathrm{mg}$ & CA-125 & yes & $>50 \mathrm{ng} / \mathrm{mL}$ & $63 \%$ & $>100 \mathrm{ng} / \mathrm{mL}$ & \\
\hline Berek 2004 & 145 & $2 \mathrm{mg}$ & CA-125 & yes & & & $>100 \mathrm{ng} / \mathrm{mL}$ & $67 \%$ \\
\hline Berek 2009 & 371 & $2 \mathrm{mg}$ & CA- 125 & no & & & & \\
\hline Braly 2009 & 40 & unknown & CA-125 & yes & & & $>100 \mathrm{ng} / \mathrm{mL}$ & $94 \%$ vs $74 \%$ \\
\hline Buzzonetti 2014 & 129 & $2 \mathrm{mg}$ & CA-125 & no & & & & \\
\hline Ehlen 2005 & 13 & $2 \mathrm{mg}$ & CA- 125 & yes & $>50 \mathrm{ng} / \mathrm{mL}$ & $45 \%$ & & \\
\hline Gordon 2004 & 20 & $2 \mathrm{mg}$ & CA-125 & yes & $>50 \mathrm{ng} / \mathrm{mL}$ & & $>100 \mathrm{ng} / \mathrm{mL}$ & $79 \%$ \\
\hline Heiss 2010 & 129 & $10-20-50-150 \mu \mathrm{g}$ & EpCAM & no & & & & \\
\hline Ma 2002 & 4 & unknown & CA-125 & no & & & & \\
\hline Method 2002 & 102 & $2 \mathrm{mg}$ & CA-125 & yes & & & $>100 \mathrm{ng} / \mathrm{mL}$ & $\begin{array}{l}13 \% \text { vs } 31 \% \\
\text { vs } 67 \%\end{array}$ \\
\hline Möbus 2003 & 44 & $2 \mathrm{mg}$ & CA-125 & yes & & & $>50 \mathrm{ng} / \mathrm{mL}$ & $77 \%$ \\
\hline Nicholson 2004 & 26 & $25 \mathrm{mg}$ & MUC1 & yes & unknown & $100 \%$ & & \\
\hline Noujaim 2001 & 184 & $2 \mathrm{mg}$ & CA-125 & yes & & & & \\
\hline Pfisterer 2006 & 36 & $2 \mathrm{mg}$ & CA-125 & no & & & & \\
\hline Reinartz 2004 & 119 & $2 \mathrm{mg}$ & CA-125 & no & & & & \\
\hline Sabbatini 2006 & 42 & $2 \mathrm{mg} / 0.2 \mathrm{mg}$ & CA-125 & no & & & & \\
\hline Sabbatini 2013 & 888 & $2 \mathrm{mg}$ & CA-125 & no & & & & \\
\hline Schultes 1998 & 75 & $2 \mathrm{mg}$ & CA- 125 & yes & $>50 \mathrm{ng} / \mathrm{mL}$ & $64 \%$ & $>250 \mathrm{ng} / \mathrm{mL}$ & \\
\hline
\end{tabular}




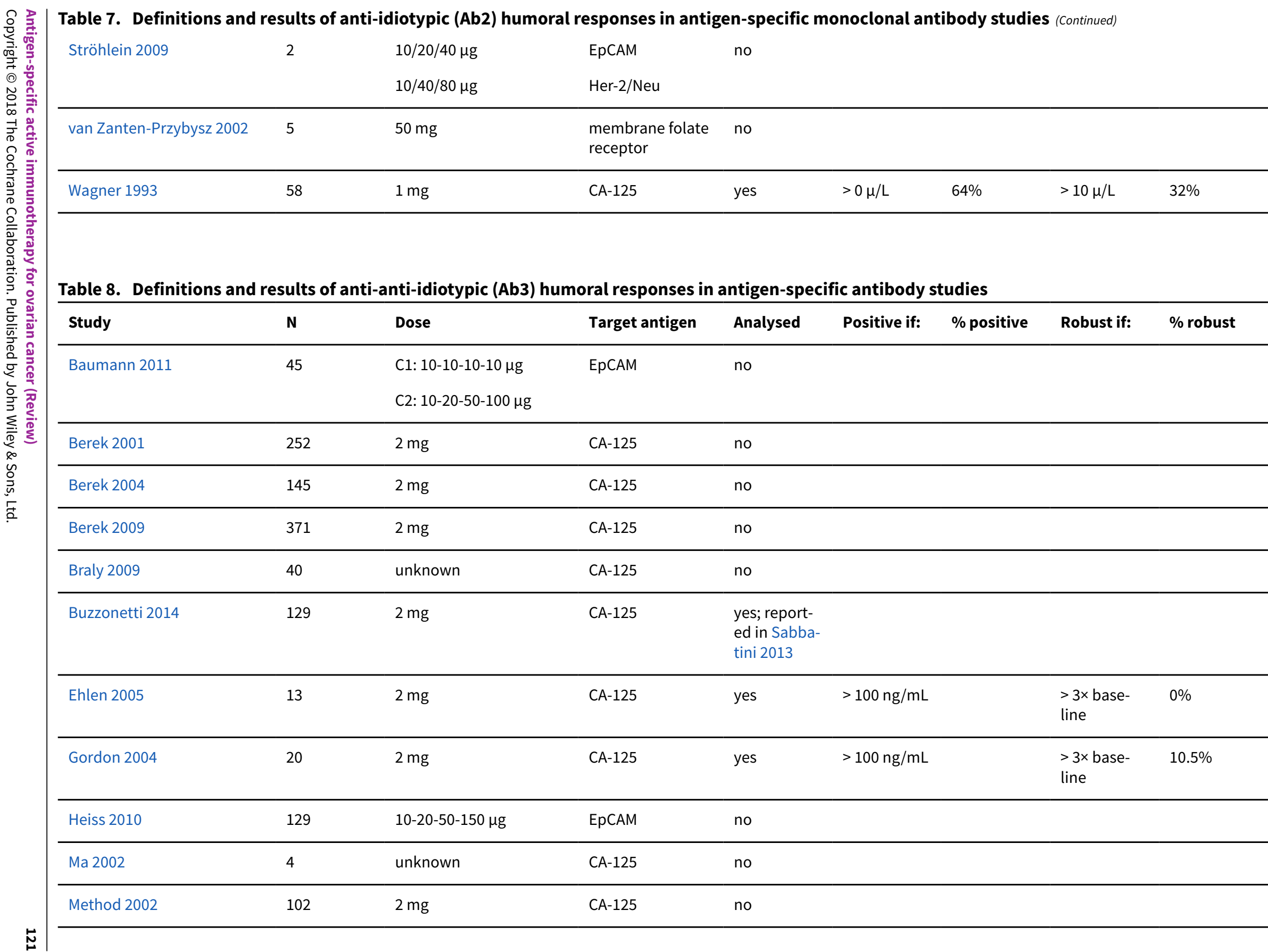




\begin{tabular}{|c|c|c|c|c|c|c|c|c|}
\hline Möbus 2003 & 44 & $2 \mathrm{mg}$ & CA-125 & yes & & & $\begin{array}{l}>3 \times \text { base- } \\
\text { line }\end{array}$ & $28 \%$ \\
\hline Nicholson 2004 & 26 & $25 \mathrm{mg}$ & MUC1 & yes & $\begin{array}{l}>0.015 \mu \mathrm{g} / \\
\mathrm{mL}\end{array}$ & $38 \%$ & & \\
\hline Noujaim 2001 & 184 & $2 \mathrm{mg}$ & CA-125 & yes & & & $\begin{array}{l}>3 \times \text { base- } \\
\text { line }\end{array}$ & $43 \%$ \\
\hline Pfisterer 2006 & 36 & $2 \mathrm{mg}$ & CA-125 & yes & $\begin{array}{l}>1000 \mathrm{ng} / \\
\mathrm{mL}\end{array}$ & $\begin{array}{l}\text { L vs S: } 100 \% \\
\text { vs } 100 \%\end{array}$ & & \\
\hline Reinartz 2004 & 119 & $2 \mathrm{mg}$ & CA-125 & yes & $>1000 \mu / \mathrm{mL}$ & $68 \%$ & & \\
\hline Sabbatini 2006 & 42 & $2 \mathrm{mg} / 0.2 \mathrm{mg}$ & CA-125 & yes & $>1000 \mu / \mathrm{mL}$ & $100 \%$ & & \\
\hline Sabbatini 2013 & 888 & $2 \mathrm{mg}$ & CA-125 & yes & unknown & $\begin{array}{l}\text { placebo: } \\
\text { stable } \\
\text { abagov- } \\
\text { omab: in- } \\
\text { crease }\end{array}$ & & \\
\hline Schultes 1998 & 75 & $2 \mathrm{mg}$ & CA-125 & yes & $>200 \mathrm{ng} / \mathrm{mL}$ & $24 \%$ & $\begin{array}{l}>3 \times \text { base- } \\
\text { line }\end{array}$ & \\
\hline Ströhlein 2009 & 2 & $10 / 20 / 40 \mu \mathrm{g}$ & EpCAM & no & & & & \\
\hline & & $10 / 40 / 80 \mu \mathrm{g}$ & Her-2/Neu & & & & & \\
\hline van Zanten-Przybysz 2002 & 5 & $50 \mathrm{mg}$ & $\begin{array}{l}\text { membrane folate } \\
\text { receptor }\end{array}$ & no & & & & \\
\hline Wagner 1993 & 58 & $1 \mathrm{mg}$ & CA-125 & no & & & & \\
\hline
\end{tabular}


Table 9. Definitions and results of humoral response evaluation in other antigen-specific immunotherapy studies

\begin{tabular}{|c|c|c|c|c|c|c|}
\hline Study & $\mathbf{N}$ & Target antigen(s) & Analysed & Assay & Positive if: & $\%$ positive \\
\hline Antonilli 2016 & 10 & $\mathrm{MUC} 1 \pm \mathrm{ErbB} 1 \pm \mathrm{CEA}$ & no & & & \\
\hline Berinstein 2012 & 6 & $\begin{array}{l}\text { topoisomerase Ila, inte- } \\
\text { grin } \beta 8 \text { subunit precursor, } \\
\text { ABI-binding protein C3, } \\
\text { TACE/ADAM17, junction } \\
\text { plakglobin, EDDR1, BAP31 }\end{array}$ & no & & & \\
\hline Berinstein 2013 & 19 & survivin & no & & & \\
\hline Brossart 2000 & 3 & Her-2/Neu, MUC1 & no & & & \\
\hline $\begin{array}{l}\text { Chianese-Bul- } \\
\text { lock } 2008\end{array}$ & 9 & FBP, Her-2/Neu, MAGE-A1 & no & & & \\
\hline Chu 2012 & 11 & Her-2/Neu, hTERT, PADRE & no & & & \\
\hline Diefenbach 2008 & 6 & NY-ESO-1 & yes & unknown & unknown & not reported \\
\hline Dijkgraaf 2015 & 6 & p53 & no & & & \\
\hline Dhodapkar 2012 & 9 & NY-ESO-1 & yes & ELISA & $>100$ & $0 \%$ \\
\hline Freedman 1998 & 21 & CEA & yes & ELISA & $\begin{array}{l}\geq 2 \times \text { pretreat- } \\
\text { ment and }> \\
\text { mean }+2 \text { SD } \\
\text { of } 10 \text { normal } \\
\text { sera }\end{array}$ & $0 \%$ \\
\hline Galanis 2010 & 63 & MUC1 & yes & unknown & unknown & $0 \%$ \\
\hline Goh 2013 & 6 & CYP1B1 & no & & & \\
\hline Gray 2016 & 56 & MUC1 & yes & ELISA & unknown & $\begin{array}{l}\text { No response mea- } \\
\text { sured }\end{array}$ \\
\hline Gribben 2005 & 3 & CEA, MUC1 & no & & & \\
\hline Gulley 2008 & 30 & Sialyl-Tn & no & & & \\
\hline Imhof 2013 & 15 & TERT, survivin & no & & & \\
\hline Kaumaya 2009 & 5 & Her-2/Neu & yes & ELISA & $\begin{array}{l}\text { high response: } \\
>0.6 \\
\text { intermediate } \\
\text { response: } 0.2 \\
\text { to } 0.6\end{array}$ & $\begin{array}{l}60 \% \text { high respons- } \\
\text { es, } 40 \% \text { intermedi- } \\
\text { ate responses }\end{array}$ \\
\hline Kawano 2014 & 42 & $\begin{array}{l}\text { personalised (max } 4 \text { out of } \\
31 \text { vacinne candidates) }\end{array}$ & yes & $\begin{array}{l}\text { Luminex } \\
\text { assay }\end{array}$ & $\begin{array}{l}1 \text { out of } 4 \text { vac- } \\
\text { cine-specif- } \\
\text { ic IgG titers is } \\
2 \text {-fold higher }\end{array}$ & $\begin{array}{l}6 \text { vaccinations: } \\
16 / 42 \\
12 \text { vaccinations: } \\
29 / 30\end{array}$ \\
\hline
\end{tabular}


Table 9. Definitions and results of humoral response evaluation in other antigen-specific immunotherapy

studies (Continued)

\begin{tabular}{|c|c|c|c|c|c|c|}
\hline Kobayashi 2014 & 56 & WT1 $1 \pm$ MUC $1 \pm$ CA-125 & no & & & \\
\hline Le 2012 & 2 & mesothelin & no & & & \\
\hline Leffers 2009a & 20 & p53 & yes & unknown & unknown & $\begin{array}{l}\text { pre-imm: } 40 \% \text {, } \\
\text { post-imm: } 45 \%\end{array}$ \\
\hline Lennerz 2014 & 7 & survivin & no & & & \\
\hline Letsch 2011 & 8 & WT1 & no & & & \\
\hline MacLean 1996 & 10 & Thomsen Friedenreich & yes & ELISA & unknown & $\begin{array}{l}80 \% \operatorname{lgA}, 90 \% \operatorname{lgM}, \\
90 \% \operatorname{lgG}, 0 \% \lg \mathrm{E}\end{array}$ \\
\hline MacLean 1992 & 34 & Sialyl-Tn & yes & ELISA & unknown & $96 \%$ \\
\hline Mohebtash 2011 & 14 & MUC1, CEA & no & & & \\
\hline
\end{tabular}

Morse $2011 \quad 8 \quad$ APC, HHR6A, BAP31, repli- no

cation protein $A$, Abl-bind-

ing protein $3 c$, cyclin I,

toposiomerase $I / \alpha / \beta$, in-

tegrin $\beta 8$ subunit precur-

sor, CDC2, TACE, g-catenin,

EEDDR1

\begin{tabular}{lllll}
\hline Nishikawa 2006 & 4 & NY-ESO-1 & no & \\
\hline $\begin{array}{l}\text { O'Cearbhaill } \\
2016\end{array}$ & 24 & GM2, Globo-H, Tn, TF, sTN & yes & ELISA
\end{tabular}

no

yes ELISA

IgM titer $>1: 80$

or at least 4- Globo- $\mathrm{H} 8 \%$,

fold increase $\quad 58 \%$, TF $67 \%$, sTn

from baseline $\quad 92 \%$

IgG: GM2 17\%,

Globo-H 58\%, Tn

$83 \%$, TF $25 \%$, sTN

$67 \%$

20/24 responded to at least 3 antigens

\begin{tabular}{|c|c|c|c|c|c|c|}
\hline Odunsi 2007 & 18 & NY-ESO-1 & yes & ELISA & unknown & $22 \%$ \\
\hline Odunsi 2012 & 22 & NY-ESO-1 & yes & ELISA & unknown & $50 \%$ \\
\hline \multirow[t]{3}{*}{ Odunsi 2014} & 12 & NY-ESO-1 & yes & ELISA & $\begin{array}{l}\text { reciprocal } \\
\text { titer }>100\end{array}$ & $\begin{array}{l}4 \text { patients remained } \\
\text { seropositive }\end{array}$ \\
\hline & & & & & & $\begin{array}{l}5 / 6 \text { became } \\
\text { seropositive }\end{array}$ \\
\hline & & & & & & $\begin{array}{l}\text { no differences be- } \\
\text { tween cohorts. }\end{array}$ \\
\hline
\end{tabular}

$\begin{array}{llll}\text { Ohno } 2009 & 6 & \text { WT1 } & \text { no }\end{array}$


Table 9. Definitions and results of humoral response evaluation in other antigen-specific immunotherapy

studies (Continued) 4 Her-2/Neu yes ELISA unknown unknown

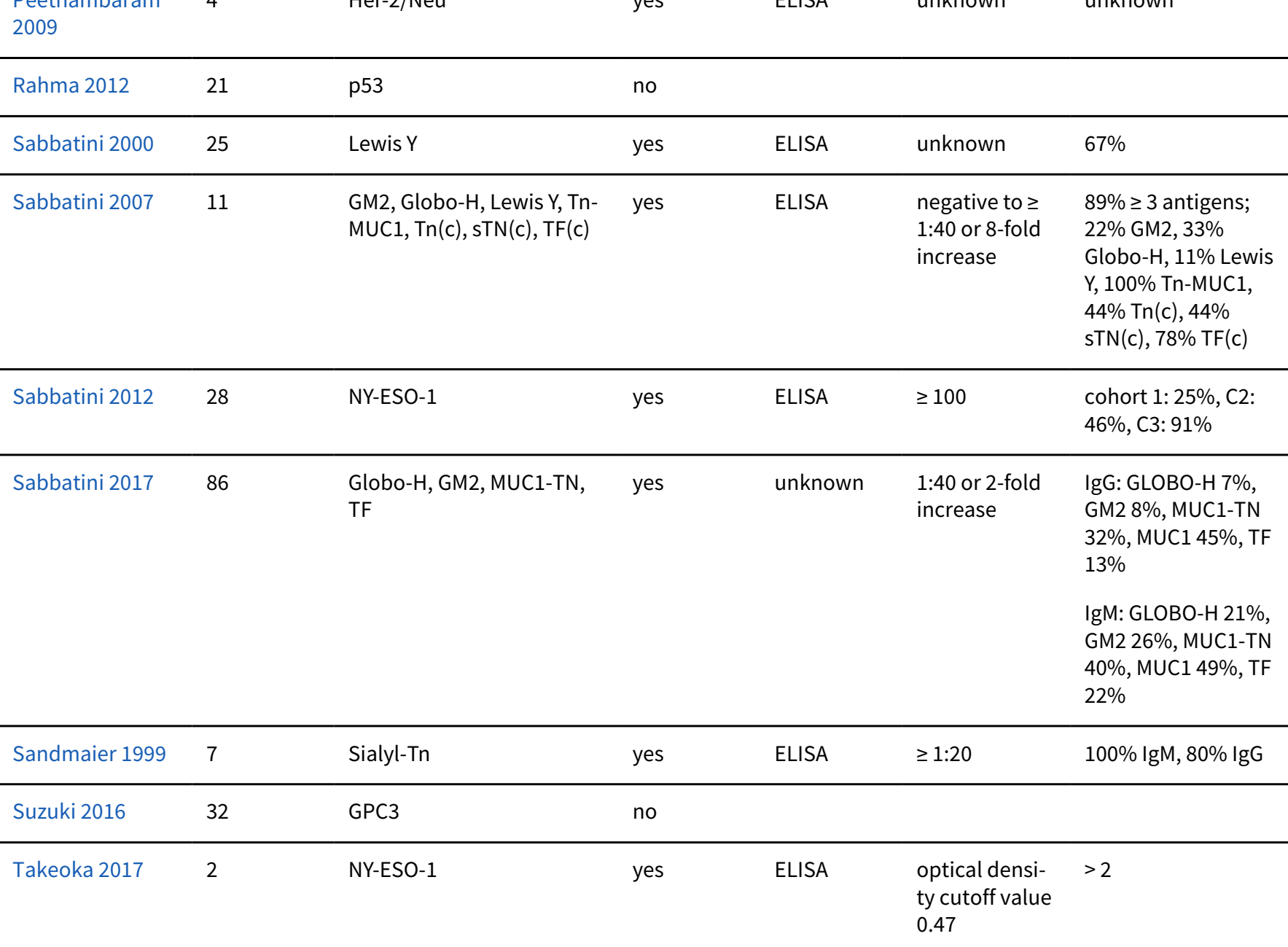

\begin{tabular}{|c|c|c|c|c|c|c|}
\hline Takeuchi 2013 & 38 & $\begin{array}{l}\text { HLA-A24: FOXM1, MELK, } \\
\text { HJURP, VEGFR1, VEGFR2 } \\
\text { HLA-A02: HIG2, VEGFR1, } \\
\text { VEGFR2 }\end{array}$ & no & & & \\
\hline Tsuda 2004 & 5 & patient-tailored cocktail & yes & ELISA & unknown & $67 \%$ \\
\hline Vermeij 2012 & 12 & p53 & no & & & \\
\hline
\end{tabular}

SD: standard deviation. 


\begin{tabular}{|c|c|c|c|c|c|c|c|}
\hline Study & $\mathbf{N}$ & Dose & $\begin{array}{l}\text { Target anti- } \\
\text { gen }\end{array}$ & Analysed & Assay & Positive if: & $\%$ positive \\
\hline Baumann 2011 & 45 & $\begin{array}{l}\mathrm{C} 1: 10-10-10-10 \\
\mathrm{ug}\end{array}$ & EpCAM & no & & & \\
\hline & & $\begin{array}{l}\text { C2: } \\
10-20-50-100 \mu \mathrm{g}\end{array}$ & & & & & \\
\hline Berek 2001 & 252 & $2 \mathrm{mg}$ & CA-125 & no & & & \\
\hline Berek 2004 & 145 & $2 \mathrm{mg}$ & CA- 125 & no & & & \\
\hline Berek 2009 & 371 & $2 \mathrm{mg}$ & CA- 125 & no & & & \\
\hline Braly 2009 & 40 & unknown & CA-125 & yes & ELISPOT & permutation test & $44 \%$ vs $21 \%$ \\
\hline Buzzonetti 2014 & 129 & $2 \mathrm{mg}$ & CA- 125 & yes & flow cytometry & $\begin{array}{l}\text { patients with a CA- } 125-C T L \text { count } \\
\text { above } 0.410 \times 10^{\wedge} 6 \text { (=90th per- } \\
\text { centile level of CA-125-specific } \\
\text { CTL count in the placebo arm) } \\
\text { for at least } 1 \text { of the time points } \\
\text { throughout the study }\end{array}$ & $\begin{array}{l}31.8 \% \text { (treatment arm) } \\
\text { vs } 26.3 \% \text { (placebo } \\
\text { arm) }\end{array}$ \\
\hline Ehlen 2005 & 13 & $2 \mathrm{mg}$ & CA-125 & yes & ELISPOT & permutation test & $\begin{array}{l}n=4 \text { CA- } 125: 75 \% ; n= \\
3 \text { oregovomab } 67 \%\end{array}$ \\
\hline Gordon 2004 & 20 & $2 \mathrm{mg}$ & CA-125 & yes & ELISPOT & permutation test & $\begin{array}{l}\mathrm{n}=18 \text { CA- } 125: 39 \% ; \mathrm{n}= \\
8 \text { oregovomab } 50 \% ; \mathrm{n} \\
=8 \text { autologous tumour } \\
\text { cells } 63 \%\end{array}$ \\
\hline Heiss 2010 & 129 & $10-20-5-150 \mu \mathrm{g}$ & EpCAM & no & & & \\
\hline Ma 2002 & 4 & unknown & CA-125 & yes & $\begin{array}{l}\text { proliferation as- } \\
\text { say }\end{array}$ & unknown & $n=4: 50 \%$ \\
\hline Method 2002 & 102 & $2 \mathrm{mg}$ & CA-125 & yes & ELISPOT & not reported & not reported \\
\hline Möbus 2003 & 44 & $2 \mathrm{mg}$ & CA-125 & no & & & \\
\hline Nicholson 2004 & 26 & $25 \mathrm{mg}$ & MUC1 & no & & & \\
\hline
\end{tabular}




\begin{tabular}{|c|c|c|c|c|c|c|c|}
\hline Noujaim 2001 & 184 & $2 \mathrm{mg}$ & CA-125 & yes & $\begin{array}{l}\text { proliferation as- } \\
\text { say/ cytokine } \\
\text { ELISA }\end{array}$ & $\begin{array}{l}\text { proliferation assay: Wilcoxon } \\
\text { signed rank test; cytokine ELISA: } \\
\text { unknown }\end{array}$ & $\begin{array}{l}n=17 \text { CA- } 12553 \% \text {; Th1 } \\
\text { cytokines } 41 \% \text {, Th2 cy- } \\
\text { tokines } 94 \%\end{array}$ \\
\hline Pfisterer 2006 & 36 & $2 \mathrm{mg}$ & CA-125 & yes & $\begin{array}{l}\text { cytokine flow } \\
\text { cytometry }\end{array}$ & $\begin{array}{l}>2 \text {-fold increase in IFN- } \gamma \text {-ex- } \\
\text { pressing T-cells }\end{array}$ & $\begin{array}{l}\text { L vs S: } n=12 \text { vs } 17 \\
\text { CD4: } 58 \% \text { vs } 29 \% ; C D 8 \\
75 \% \text { vs } 18 \%\end{array}$ \\
\hline Reinartz 2004 & 119 & $2 \mathrm{mg}$ & CA- 125 & no & & & \\
\hline Sabbatini 2006 & 42 & $2 \mathrm{mg} / 0.2 \mathrm{mg}$ & CA- 125 & yes & ELISPOT & $\begin{array}{l}\text { spots experimental wells - con- } \\
\text { trol wells }>20 \text { and experimental } \\
\text { wells/control wells }>1.5 \times\end{array}$ & $\mathrm{n}=5: 80 \%$ \\
\hline Sabbatini 2013 & 888 & $2 \mathrm{mg}$ & CA- 125 & yes & not reported & & not reported \\
\hline Schultes 1998 & 75 & $2 \mathrm{mg}$ & CA- 125 & no & & & \\
\hline Ströhlein 2009 & 2 & $\begin{array}{l}10 / 20 / 40 \mu g \\
10 / 40 / 80 \mu g\end{array}$ & $\begin{array}{l}\text { EpCAM } \\
\text { Her-2/Neu }\end{array}$ & yes & $\begin{array}{l}\text { IFN- } \gamma \text { secretion } \\
\text { assay }\end{array}$ & unknown & $\begin{array}{l}\text { EpCAM } n=1(100 \%) \\
\text { Her-2/Neu } n=1(0 \%)\end{array}$ \\
\hline $\begin{array}{l}\text { van Zanten-Przy- } \\
\text { bysz } 2002\end{array}$ & 5 & $50 \mathrm{mg}$ & $\begin{array}{l}\text { membrane fo- } \\
\text { late receptor }\end{array}$ & yes & $\begin{array}{l}\text { proliferation as- } \\
\text { say }\end{array}$ & unknown & $0 \%$ \\
\hline Wagner 1993 & 58 & $1 \mathrm{mg}$ & CA- 125 & yes & $\begin{array}{l}\text { leucocyte mi- } \\
\text { gration inhibi- } \\
\text { tion assay }\end{array}$ & unknown & $21 \%$ \\
\hline
\end{tabular}

CTL: cytotoxic T-cell. 
Table 11. Definitions and results of cellular responses in other antigen-specific immunotherapy studies

\begin{tabular}{|c|c|c|c|c|c|c|}
\hline Study & $\mathbf{N}$ & $\begin{array}{l}\text { Target anti- } \\
\operatorname{gen}(\mathbf{s})\end{array}$ & Analysed & Assay & Positive if: & $\%$ positive \\
\hline $\begin{array}{l}\text { Antonilli } \\
2016\end{array}$ & 10 & $\begin{array}{l}\mathrm{MUC1} \pm \mathrm{ErbB} 1 \\
\pm \mathrm{CEA}\end{array}$ & yes & $\begin{array}{l}\text { IFN- } \gamma \text { ELISPOT } \\
\text { delayed hy- } \\
\text { persensitvity } \\
\text { test }\end{array}$ & $\begin{array}{l}\text { ELISPOT: } 2 \text {-fold increase in } \\
\text { IFN- } \gamma \text { production } \\
\text { Delayed hypersensitvity } \\
\text { test: unknown }\end{array}$ & $\begin{array}{l}\text { ELISPOT: } 6 / 7+0 / 3 \\
\text { Delayed hypersen- } \\
\text { sitvity test: } 3 / 7\end{array}$ \\
\hline $\begin{array}{l}\text { Berinstein } \\
2012\end{array}$ & 6 & $\begin{array}{l}\text { topoiso- } \\
\text { merase Ila, } \\
\text { integrin } \beta 8 \\
\text { subunit pre- } \\
\text { cursor, ABI- } \\
\text { binding pro- } \\
\text { tein C3, TACE/ } \\
\text { ADAM17, junc- } \\
\text { tion plakglo- } \\
\text { bin, EDDR1, } \\
\text { BAP31 }\end{array}$ & yes & $\begin{array}{l}\text { pentamer } \\
\text { staining }(C D 8)\end{array}$ & $\begin{array}{l}>2 \times \text { increase in pen- } \\
\text { tamer-positive CD8-cells }\end{array}$ & $\begin{array}{l}83 \% \text { against at least } \\
1 \text { peptide }\end{array}$ \\
\hline $\begin{array}{l}\text { Berinstein } \\
2013\end{array}$ & 19 & survivin & yes & $\begin{array}{l}\text { ELISPOT } \\
\text { tetramer } \\
\text { staining } \\
\text { intracellu- } \\
\text { lar cytokine } \\
\text { staining }\end{array}$ & unknown & $\begin{array}{l}\text { combined results co- } \\
\text { hort } 2+3: 92 \% \text { on } \geq 2 \\
\text { assays }\end{array}$ \\
\hline $\begin{array}{l}\text { Brossart } \\
2000\end{array}$ & 3 & $\begin{array}{l}\text { Her- } 2 / \mathrm{Neu} \\
\text { MUC1 }\end{array}$ & yes & $\begin{array}{l}\text { intracellular } \\
\text { IFN- } \gamma \text { staining } \\
\text { (CD8) }\end{array}$ & unknown & $\begin{array}{l}n=1: \text { Her-2/Neu } \\
100 \% ; n=2: \text { MUC1 } \\
50 \%\end{array}$ \\
\hline $\begin{array}{l}\text { Chi- } \\
\text { anese-Bul- } \\
\text { lock } 2008\end{array}$ & 9 & $\begin{array}{l}\text { FBP, Her-2/ } \\
\text { Neu, MAGE-A1 }\end{array}$ & yes & ELISPOT (CD8) & unknown & $\begin{array}{l}\mathrm{n}=9: \text { FBP } 40 \%, \\
\text { Her-2/Neu 83\%, } \\
\text { MAGE-A1 83\% }\end{array}$ \\
\hline Chu 2012 & 14 & $\begin{array}{l}\text { Her-2/Neu, } \\
\text { hTERT, PADRE }\end{array}$ & yes & $\begin{array}{l}\text { ELISPOT } \\
\text { tetramer } \\
\text { staining (CD8) }\end{array}$ & unknown & $\begin{array}{l}\text { hTERT: cohort 1: } \\
\text { 100\%, cohort 2: } \\
100 \% \\
\text { Her-2/Neu: cohort 1: } \\
60 \% \text {, cohort 2: } 0 \% \\
\text { PADRE: cohort 1: } \\
60 \% \text {, cohort 2: } 60 \%\end{array}$ \\
\hline $\begin{array}{l}\text { Diefenbach } \\
2008\end{array}$ & 6 & NY-ESO-1 & yes & $\begin{array}{l}\text { ELISPOT } \\
\text { intracellu- } \\
\text { lar cytokine } \\
\text { staining }\end{array}$ & unknown & not reported \\
\hline $\begin{array}{l}\text { Dijkgraaf } \\
2015\end{array}$ & 6 & $\begin{array}{l}\text { Cohort 3: } \\
\text { gemcitabine, } \\
\text { PegIntron, } \\
\text { and p53 SLP } \\
\text { vaccine }\end{array}$ & yes & IFN- $\gamma$ ELISPOT & $\begin{array}{l}>3 \text {-fold change compared } \\
\text { to baseline }\end{array}$ & cohort 3: 6/6 \\
\hline
\end{tabular}


Table 11. Definitions and results of cellular responses in other antigen-specific immunotherapy studies (Continued)

$\begin{array}{lllll}\text { Dhodapkar 9 } 9 \text { NY-ESO-1 } & \text { yes } & \text { ELISPOT/ } & \text { specific spots }>30 \text { and }>3 \times & \text { both assays } n=9: \\ & & \text { Tetramer } & \text { spots irrelevant control }> & 67 \% \\ & & \text { staining (CD8) } & \begin{array}{l}0.1 \% \text { tetramer-positive CD8- } \\ \text { cells }\end{array}\end{array}$

\begin{tabular}{|c|c|c|c|c|c|c|}
\hline $\begin{array}{l}\text { Freedman } \\
1998\end{array}$ & 30 & Sialyl-Tn & no & & & \\
\hline $\begin{array}{l}\text { Galanis } \\
2010\end{array}$ & 21 & CEA & no & & & \\
\hline Goh 2013 & 63 & MUC1 & yes & unknown & & not reported \\
\hline Gray 2016 & 56 & MUC1 & yes & $\begin{array}{l}\text { intracellu- } \\
\text { lar cytokine } \\
\text { staining (CD4/ } \\
\text { CD8) }\end{array}$ & unknown & $\begin{array}{l}\text { inadequately report- } \\
\text { ed }\end{array}$ \\
\hline $\begin{array}{l}\text { Gribben } \\
2005\end{array}$ & 6 & CYP1B1 & yes & ELISPOT & $\begin{array}{l}\text { spots minus negative con- } \\
\text { trol }>20 / 10^{6} \text { PBMC and }>2 \times \\
\text { baseline }\end{array}$ & $n=5: 20 \%$ \\
\hline Gulley 2008 & 3 & CEA, MUC1 & yes & $\begin{array}{l}\text { ELISPOT } \\
(\mathrm{CD} 8) / \text { IFN- } \gamma \\
\text { ELISA (CD4) }\end{array}$ & $\begin{array}{l}\text { ELISPOT: } \geq 2 \text {-fold increase } \\
\text { in IFN- } \gamma \text {-secreting cells } \\
\text { IFN- } \gamma \text { ELISA: unknown }\end{array}$ & $\begin{array}{l}\mathrm{n}=3: 100 \% \text { CEA } \\
\mathrm{n}=3: 33 \% \text { CEA }\end{array}$ \\
\hline Imhof 2013 & 15 & TERT, survivin & yes & $\begin{array}{l}\text { intracellu- } \\
\text { lar cytokine } \\
\text { staining }\end{array}$ & unknown & overall > 90\% \\
\hline
\end{tabular}

\begin{tabular}{|c|c|c|c|c|c|c|}
\hline $\begin{array}{l}\text { Kaumaya } \\
2009\end{array}$ & 5 & Her-2/Neu & no & & & \\
\hline $\begin{array}{l}\text { Kawano } \\
2014\end{array}$ & 42 & $\begin{array}{l}\text { personalised } \\
\text { (max } 4 \text { out } \\
\text { of } 31 \text { vaccine } \\
\text { candidates) }\end{array}$ & yes & ELISPOT & $\begin{array}{l}\text { 2-fold higher values post- } \\
\text { vaccination than pre-vacci- } \\
\text { nation }\end{array}$ & $\begin{array}{l}6 \text { vaccinations: } 18 / 42 \\
12 \text { vaccinations: } \\
19 / 42\end{array}$ \\
\hline $\begin{array}{l}\text { Kobayashi } \\
2014\end{array}$ & 56 & $\begin{array}{l}\text { WT } 1 \pm \text { MUC1 } 1 \\
\text { CA-125 }\end{array}$ & yes & $\begin{array}{l}\text { Flow cytome- } \\
\text { try (CD4/CD8/ } \\
\text { NK) } \\
\text { Tetramer } \\
\text { staining (WT-1 } \\
\text { CTLs) }\end{array}$ & unknown & $\begin{array}{l}\text { flow cytometry: no } \\
\text { chances in CD4+, } \\
\text { CD8+, and NK cell } \\
\text { frequency } \\
\text { tetramer staining: } \\
\text { 12/17 increased }\end{array}$ \\
\hline Le 2012 & 2 & mesothelin & yes & ELISPOT (CD8) & $\begin{array}{l}\text { specific spots }>2 \times \text { baseline } \\
\text { and } \geq 1 \text { per } 10^{5} \text { PBMC }\end{array}$ & $\begin{array}{l}\mathrm{n}=1 \text { evaluable, } \\
\text { mesothelin-specific } \\
\text { CD8 cells present }\end{array}$ \\
\hline $\begin{array}{l}\text { Leffers } \\
2009 a\end{array}$ & 20 & p53 & yes & $\begin{array}{l}\text { ELISPOT } \\
\text { proliferation } \\
\text { assay } \\
\text { intracellu- } \\
\text { lar cytokine }\end{array}$ & $\begin{array}{l}\text { specific spots } \geq 10 / 10^{5} \\
\text { PBMC and } \geq 3 \times \text { pre-immuni- } \\
\text { sation } \\
\mathrm{cpm}>1000 / \text { min, } \mathrm{SI} \geq 3 \text {, and } \\
\geq 2 \times \text { pre-immunisation } \\
\geq 3 \text { pre-immunisation }\end{array}$ & $\begin{array}{l}n=18: 100 \% \\
n=17: 82 \% \\
n=5: C D 80 \%, C D 4 \\
100 \%\end{array}$ \\
\hline
\end{tabular}


Table 11. Definitions and results of cellular responses in other antigen-specific immunotherapy studies (Continued) staining (CD4/ CD8)

\begin{tabular}{llll}
\hline Lennerz & 7 & survivin $\quad$ yes & ELISPOT/HLA- \\
2014 & & multimer \\
& & staining
\end{tabular}

ELISPOT (CD8): spot number $>10$ and 2-fold higher than background and 2-fold higher than standard deviation of all combined negative values

HLA-multimer staining: detection of $>50$ cells in the multimer gate, minimum percentage of $0.03 \% \mathrm{CD} 8+$ cells

\begin{tabular}{|c|c|c|c|c|c|c|}
\hline Letsch 2011 & 8 & WT1 & yes & $\begin{array}{l}\text { tetramer } \\
\text { staining }\end{array}$ & unknown & not reported \\
\hline
\end{tabular}

\begin{tabular}{llll}
\hline MacLean & 10 & Sialyl-Tn
\end{tabular}

1996

\begin{tabular}{lll}
\hline $\begin{array}{l}\text { MacLean } \\
1992\end{array}$ & 34 & $\begin{array}{l}\text { Thomsen } \\
\text { Friedenreich no }\end{array}$ \\
\hline
\end{tabular}

Mohebtash $14 \quad$ MUC1, CEA yes ELISPOT (CD8) $\geq 2 \times$ pre-immunisation

2011

\begin{tabular}{|c|c|c|c|c|c|c|}
\hline Morse 2011 & 8 & $\begin{array}{l}\text { APC, HHR6A, } \\
\text { BAP31, repli- } \\
\text { cation protein } \\
\text { A, Abl-bind- } \\
\text { ing protein } 3 c \text {, } \\
\text { cyclin I, topo- } \\
\text { siomerase } \\
\text { Ila/ } \beta \text {, integrin } \\
\beta 8 \text { subunit } \\
\text { precursor, } \\
\text { CDC2, TACE, g- } \\
\text { catenin, EED- } \\
\text { DR1 }\end{array}$ & yes & ELISPOT & $\begin{array}{l}>40 \text { spots } / 10^{6} \text { PBMC over } \\
\text { pre-vaccination }\end{array}$ & $n=8: 63 \%$ \\
\hline $\begin{array}{l}\text { Nishikawa } \\
2006\end{array}$ & 4 & NY-ESO-1 & yes & ELISPOT (CD4) & unknown & $n=4: 75 \%$ \\
\hline $\begin{array}{l}\text { O'Cearb- } \\
\text { haill } 2016\end{array}$ & 24 & $\begin{array}{l}\text { GM2, Globo-H, } \\
\text { Tn, TF, sTN }\end{array}$ & no & & & \\
\hline $\begin{array}{l}\text { Odunsi } \\
2007\end{array}$ & 18 & NY-ESO-1 & yes & $\begin{array}{l}\text { ELISPOT (CD4/ } \\
\text { CD8) }\end{array}$ & mean $\pm 3 S D$ & $\begin{array}{l}n=18 ; C D 4: 83 \%, \\
C D 8: 33 \%\end{array}$ \\
\hline $\begin{array}{l}\text { Odunsi } \\
2012\end{array}$ & 22 & NY-ESO-1 & yes & $\begin{array}{l}\text { ELISPOT (CD4/ } \\
\text { CD8) } \\
\text { intracellu- } \\
\text { lar cytokine } \\
\text { staining (CD8) }\end{array}$ & unknown & $\begin{array}{l}\text { CD4: } 91 \% \\
\text { CD8: } 45 \%\end{array}$ \\
\hline
\end{tabular}

Antigen-specific active immunotherapy for ovarian cancer (Review)

ex vivo ELISPOT: $\mathrm{n}=$ $0 / 7$

in vivo ELISPOT: $\mathrm{n}=$ $1 / 2$

ex vivo multimer: $\mathrm{n}=$ $2 / 5$

in vivo multimer: $\mathrm{n}=$ $3 / 4$

$\mathrm{n}=2: 0 \%$; MUC1-specific CD 8 cells $50 \%$, CEA-specific CD8 cells 
Table 11. Definitions and results of cellular responses in other antigen-specific immunotherapy studies (Continued)

\begin{tabular}{|c|c|c|c|c|c|c|}
\hline $\begin{array}{l}\text { Odunsi } \\
2014\end{array}$ & 12 & NY-ESO-1 & yes & $\begin{array}{l}\text { ELISPOT (CD4/ } \\
\text { CD8) } \\
\text { tetramer } \\
\text { staining }\end{array}$ & $\begin{array}{l}\text { ELISPOT: spot numbers in } \\
\text { the presence of target cells } \\
\text { exceeded cutoff value ( }>50 \\
\text { spots } / 50,000 \text { cells) + at least } \\
3 \text { times more spots than un- } \\
\text { pulsed target cells } \\
\text { tetramer: }>0.1 \% \text { tetramer- } \\
\text { positive cells are CD } 8+T- \\
\text { cells and at least } 3 \text { times } \\
\text { more than the percent- } \\
\text { age obtained with control } \\
\text { tetramer. }\end{array}$ & $\begin{array}{l}\text { CD8: } 5 / 11 \text { ( } 45 \%) \text {, of } \\
\text { which } 3 \text { de novo in- } \\
\text { ductions } \\
\text { CD4: } 7 / 10 \text { ( } 70 \%) \text {, of } \\
\text { which } 2 \text { de novo re- } \\
\text { sponses } \\
\text { tetramer staining: 2) } \\
\text { NY-ESO-1 CD8 cell ex } \\
\text { pansion }\end{array}$ \\
\hline
\end{tabular}

\begin{tabular}{|c|c|c|c|c|c|c|}
\hline Ohno 2009 & 6 & WT1 & no & & & \\
\hline $\begin{array}{l}\text { Peetham- } \\
\text { baram } 2009\end{array}$ & 4 & Her-2/Neu & yes & $\begin{array}{l}\text { proliferation } \\
\text { assay } \\
\text { ELISPOT assay }\end{array}$ & unknown & $\begin{array}{l}\text { not reported sep- } \\
\text { arately for ovarian } \\
\text { cancer patients }\end{array}$ \\
\hline $\begin{array}{l}\text { Rahma } \\
2012\end{array}$ & 21 & p53 & yes & $\begin{array}{l}\text { ELISPOT } \\
\text { tetramer } \\
\text { staining }\end{array}$ & $\geq 2 \times$ pre-immunisation & $\begin{array}{l}\text { cohort 1: } 64 \% \text {, co- } \\
\text { hort 2: } 83 \%\end{array}$ \\
\hline
\end{tabular}

\begin{tabular}{|c|c|c|c|c|c|c|}
\hline $\begin{array}{l}\text { Sabbatini } \\
2000\end{array}$ & 25 & Lewis Y & no & & & \\
\hline $\begin{array}{l}\text { Sabbatini } \\
2007\end{array}$ & 11 & $\begin{array}{l}\text { GM2, Globo- } \\
\text { H, Lewis Y, Tn- } \\
\text { MUC1, Tn(c), } \\
\operatorname{sTN}(c), \operatorname{TF}(c)\end{array}$ & no & & & \\
\hline $\begin{array}{l}\text { Sabbatini } \\
2012\end{array}$ & 28 & NY-ESO-1 & yes & $\begin{array}{l}\text { ELISPOT (CD4/ } \\
\text { CD8) }\end{array}$ & $\begin{array}{l}>50 \text { spots } / 5 \times 10^{4} \text { cells and } \\
>3 \times \text { unstimulated cells }\end{array}$ & $\begin{array}{l}\text { CD4: } 100 \% \text { in cohort } \\
1,2 \text {, and } 3 \\
\text { CD8: cohort } 1: 0 \% \text {, } \\
\text { cohort } 2: 62 \%, \text { co- } \\
\text { hort 3: } 92 \%\end{array}$ \\
\hline $\begin{array}{l}\text { Sabbatini } \\
2017\end{array}$ & 171 & $\begin{array}{l}\text { Globo-H, GM2, } \\
\text { MUC1-TN, TF }\end{array}$ & no & & & \\
\hline $\begin{array}{l}\text { Sandmaier } \\
1999\end{array}$ & 7 & Sialyl-Tn & yes & $\begin{array}{l}\text { proliferation } \\
\text { assaya }\end{array}$ & $\begin{array}{l}\text { > upper limit of normal (SI } \\
2.35)\end{array}$ & $\mathrm{n}=4: 50 \%$ \\
\hline Suzuki 2016 & 32 & GPC3 & yes & ELISPOT (CD8) & unknown & $n=15 / 24: 62.5 \%$ \\
\hline $\begin{array}{l}\text { Takeoka } \\
2017\end{array}$ & 2 & NY-ESO-I & yes & $\begin{array}{l}\text { IFN- } \gamma \text { catch as- } \\
\text { say (CD4/CD8) }\end{array}$ & $>0.5 \%$ & $\begin{array}{l}C D 4: n=2 ;>5 \% \\
C D 8: n=2 ; 1 \% \text { to } 5 \%\end{array}$ \\
\hline $\begin{array}{l}\text { Takeuchi } \\
2013\end{array}$ & 38 & $\begin{array}{l}\text { HLA-A24: } \\
\text { FOXM1, MELK, } \\
\text { HJURP, VEG- } \\
\text { FR1, VEGFR2 }\end{array}$ & yes & unknown & unknown & $\begin{array}{l}\text { inadequately report- } \\
\text { ed }\end{array}$ \\
\hline
\end{tabular}


Table 11. Definitions and results of cellular responses in other antigen-specific immunotherapy studies (Continued) HLA-A02:

HIG2, VEGFR1, VEGFR2

\begin{tabular}{|c|c|c|c|c|c|c|}
\hline Tsuda 2004 & 5 & $\begin{array}{l}\text { patient-tai- } \\
\text { lored cocktail }\end{array}$ & yes & IFN- $\gamma$ ELISA & unclear & $\begin{array}{l}\mathrm{n}=2 \text { after } 6 \text { vacc } \\
100 \% ; \mathrm{n}=1 \text { after } 12 \\
\text { vacc } 100 \%\end{array}$ \\
\hline $\begin{array}{l}\text { Vermeij } \\
2012\end{array}$ & 12 & p53 & yes & $\begin{array}{l}\text { ELISPOT } \\
\text { proliferation } \\
\text { assay }\end{array}$ & $\begin{array}{l}\text { specific spots } \geq 10 / 10^{5} \\
\text { PBMC and } \geq 3 \times \text { pre-immuni- } \\
\text { sation } \\
\text { cpm }>1000 / \text { min, } \mathrm{SI} \geq 3 \text {, and } \\
\geq 2 \times \text { pre-immunisation }\end{array}$ & $\begin{array}{l}90 \% \text { after } 2 \text { vacc, } \\
87.5 \% \text { after } 4 \text { vacc } \\
80 \% \text { after } 2 \text { vacc, } \\
62.5 \% \text { after } 4 \text { vacc }\end{array}$ \\
\hline
\end{tabular}

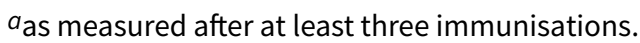

C1: cohort 1.

SD: standard deviation.

SI: stimulation index. 


\begin{tabular}{|c|c|c|c|c|c|c|c|c|}
\hline Study & $\mathbf{N}$ & Dose & Target antigen & Analysed & Positive if: & $\%$ positive & Robust if: & $\%$ robust \\
\hline Baumann 2011 & 45 & $\mathrm{C} 1: 10-10-10-10 \mu \mathrm{g}$ & EpCAM & yes & unknown & $\mathrm{C} 1: 61 \%, \mathrm{C} 2$ & & \\
\hline & & $\mathrm{C} 2: 10-20-50-100 \mu \mathrm{g}$ & & & & & & \\
\hline Berek 2001 & 252 & $2 \mathrm{mg}$ & CA-125 & yes & & & $\begin{array}{l}>5000 \mathrm{ng} / \\
\mathrm{mL}\end{array}$ & $51 \%$ \\
\hline Berek 2004 & 145 & $2 \mathrm{mg}$ & CA-125 & yes & $>200 \mathrm{ng} / \mathrm{mL}$ & unknown & $\begin{array}{l}>5000 \mathrm{ng} / \\
\mathrm{mL}\end{array}$ & $59 \%$ \\
\hline Berek 2009 & 371 & $2 \mathrm{mg}$ & CA- 125 & yes & unknown & n.r. & & \\
\hline Braly 2009 & 40 & unknown & CA-125 & yes & unknown & $\begin{array}{l}\text { SIM vs OWD: } \\
100 \% \text { vs } 80 \%\end{array}$ & $\begin{array}{l}>3000 \mathrm{ng} / \\
\mathrm{mL}\end{array}$ & $\begin{array}{l}\text { SIM vs OWD: } \\
88 \% \text { vs } 74 \%\end{array}$ \\
\hline Buzzonetti 2014 & 129 & $2 \mathrm{mg}$ & CA-125 & $\begin{array}{l}\text { yes; report- } \\
\text { ed in Sabba- } \\
\text { tini } 2013\end{array}$ & & & & \\
\hline Ehlen 2005 & 13 & $2 \mathrm{mg}$ & CA- 125 & yes & $>200 \mathrm{ng} / \mathrm{mL}$ & $100 \%$ & $\begin{array}{l}>5000 \mathrm{ng} / \\
\mathrm{mL}\end{array}$ & $58 \%$ \\
\hline Gordon 2004 & 20 & $2 \mathrm{mg}$ & CA- 125 & yes & $>200 \mathrm{ng} / \mathrm{mL}$ & unknown & $\begin{array}{l}>5000 \mathrm{ng} / \\
\mathrm{mL}\end{array}$ & $79 \%$ \\
\hline Heiss 2010 & 129 & $10-20-50-150 \mu \mathrm{g}$ & EpCAM & yes & unknown & not reported & & \\
\hline Ma 2002 & 4 & unknown & CA-125 & no & & & & \\
\hline Method 2002 & 102 & $2 \mathrm{mg}$ & CA-125 & yes & $>200 \mathrm{ng} / \mathrm{mL}$ & unknown & unknown & $\begin{array}{l}4 \% \text { vs } 36 \% \\
\text { vs } 39 \%\end{array}$ \\
\hline Möbus 2003 & 44 & $2 \mathrm{mg}$ & CA-125 & yes & & & $\begin{array}{l}>5000 \mathrm{ng} / \\
\mathrm{mL}\end{array}$ & $68 \%$ \\
\hline Nicholson 2004 & 26 & $25 \mathrm{mg}$ & MUC1 & no & & & & \\
\hline Noujaim 2001 & 184 & $2 \mathrm{mg}$ & CA- 125 & no & & & & \\
\hline Pfisterer 2006 & 36 & $2 \mathrm{mg}$ & CA-125 & yes & $>15 \mathrm{ng} / \mathrm{mL}$ & $\begin{array}{l}\text { L vs S: } 94 \% \text { vs } \\
100 \%\end{array}$ & & \\
\hline
\end{tabular}




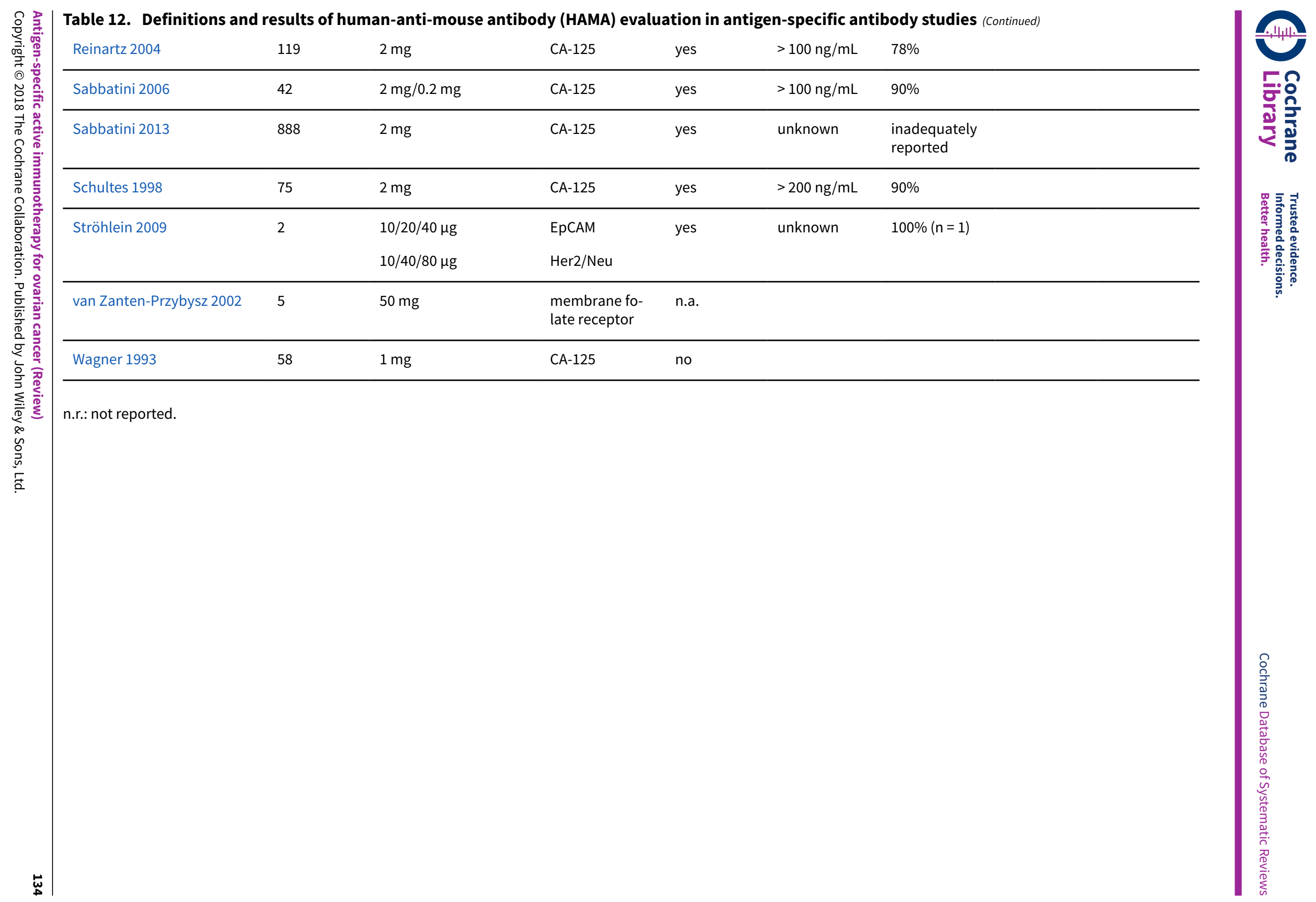




\section{APPENDICES}

\section{Appendix 1. CENTRAL search strategy}

\#1 MeSH descriptor: [Ovarian Neoplasms] explode all trees \#2 ovar* near/5 (cancer* or neoplas* or tumor $^{\star}$ or tumour $^{\star}$ or carcinoma* $^{\star}$ or adenocarcinoma* or malignan ${ }^{\star}$ )

\#3 \#1 or \#2

\#4 MeSH descriptor: [Immunotherapy, Active] explode all trees

\#5 MeSH descriptor: [Cancer Vaccines] explode all trees

\#6 immunotherapy or vaccination* or vaccine* or immunization or immunisation

\#7 \#4 or \#5 or \#6

\#8 MeSH descriptor: [Antigens, Neoplasm] explode all trees

\#9 antigen*

$\# 10 \# 8$ or \#9

\#11 MeSH descriptor: [T-Lymphocytes] explode all trees

$\# 12$ (T cell ${ }^{\star}$ ) or T-cell* or (T lymphocyte*) or T-lymphocyte* or CD4 $^{\star}$ or CD8*

\#13 \#11 or \#12

$\# 14$ \#3 and \#7 and \#10 and \#13

\section{Appendix 2. MEDLINE search strategy}

MEDLINE Ovid

1 exp Ovarian Neoplasms/

2 (ovar* adj5 (cancer* or neoplas* or tumor $^{\star}$ or tumour* or carcinoma* or adenocarcinoma* or malignan*)).mp.

31 or 2

4 exp Immunotherapy, Active/

5 Cancer Vaccines/

6 (immunotherapy or vaccination* or vaccine $^{\star}$ or immunization or immunisation).mp.

74 or 5 or 6

8 exp Antigens, Neoplasm/

9 antigen ${ }^{\star} . \mathrm{mp}$.

108 or 9

11 exp T-Lymphocytes/

12 (T cell* $^{\star}$ or T-cell* or T lymphocyte* or T-lymphocyte* or CD4* or CD8*).mp.

1311 or 12

143 and 7 and 10 and 13

key:

$\mathrm{mp}=$ title, abstract, original title, name of substance word, subject heading word, protocol supplementary concept, rare disease supplementary concept, unique identifier

\section{Appendix 3. Embase search strategy}

Embase Ovid

1 exp ovary tumor/

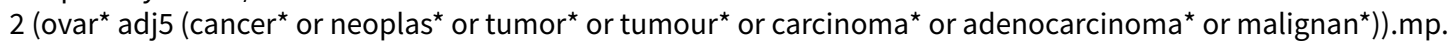

31 or 2

4 active immunization/

5 cancer vaccine/

6 (immunotherapy or vaccination* or vaccine* or immunization or immunisation).mp.

74 or 5 or 6

8 exp tumor antigen/

9 antigen*.mp.

108 or 9

11 exp T lymphocyte/

12 (T cell $^{\star}$ or T-cell ${ }^{\star}$ or T lymphocyte* or T-lymphocyte* or CD4 $^{\star}$ or CD8 $8^{\star}$ ).mp.

1311 or 12

143 and 7 and 10 and 13

key: 
$\mathrm{mp}=$ title, abstract, subject headings, heading word, drug trade name, original title, device manufacturer, drug manufacturer, device trade name, keyword

\section{Appendix 4. Data extraction form}

\section{CRITICAL REVIEW \& DATA EXTRACTION FORM}

Review Title: Antigen-specific active immunotherapy for ovarian cancer

Date: Reviewer:

Study Title:

\section{First Author}

Year of Publication

Country of Publication

Publication Type

Journal/Abstract/Other (specify)

\section{Study Characteristics}

\section{Study}

\section{Study inclusion criteria}

Study exclusion criteria

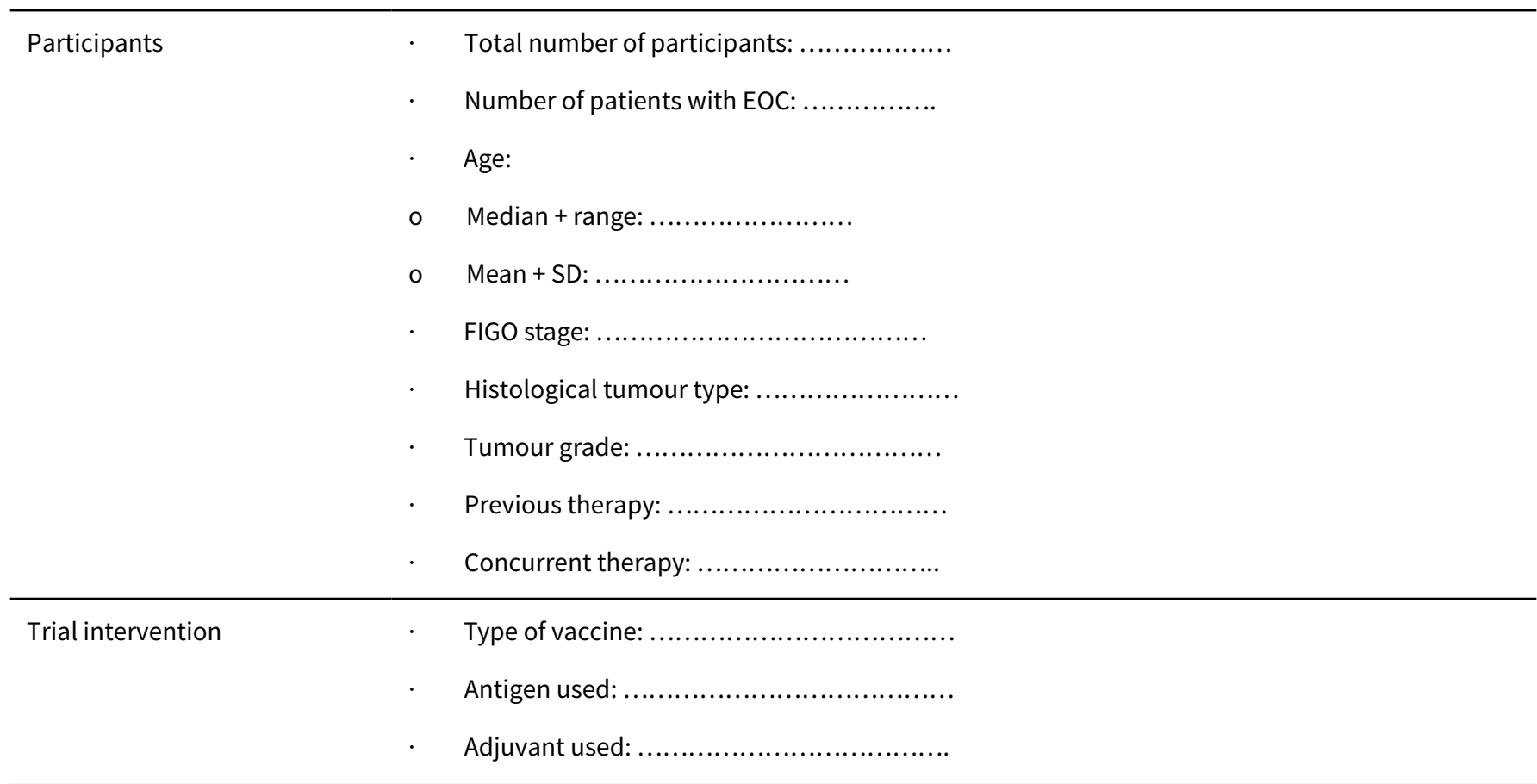




\section{Outcomes}

\section{Trial}

$\mathrm{N}+$ reason

Patients excluded during trial

\section{Patients lost to follow-up}

\begin{tabular}{|c|c|}
\hline Clinical responses & $\mathbf{N}$ \\
\hline $\begin{array}{l}\text { CA-125 levels according to } \\
\text { GCIG definition }\end{array}$ & 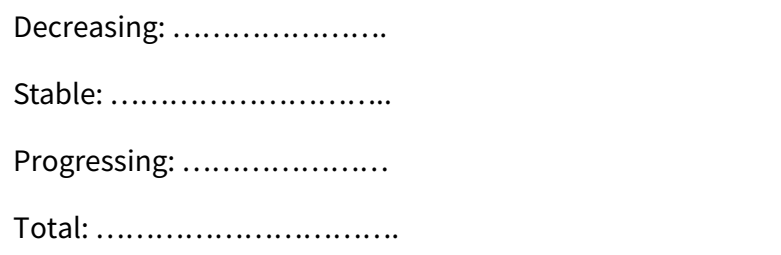 \\
\hline $\begin{array}{l}\text { Tumour response according to } \\
\text { RECIST or WHO criteria }\end{array}$ & 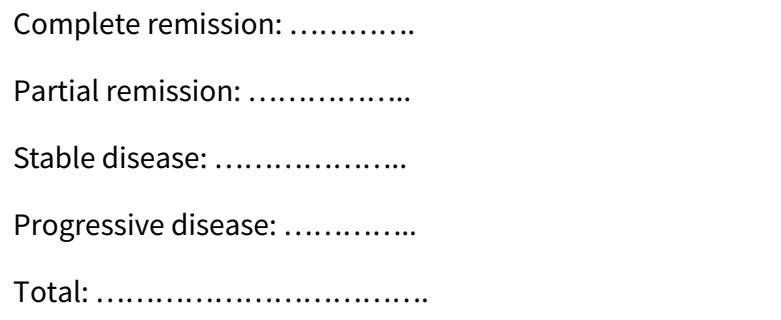 \\
\hline $\begin{array}{l}\text { Post-immunotherapy treat- } \\
\text { ment }\end{array}$ & $\begin{array}{l}\text { Administered: Yes } ? \text { No } ? \\
\text { If yes: specify response to post-immunotherapy treatment: } \\
\text { Complete remission: ............ } \\
\text { Partial remission: .............. } \\
\text { Stable disease: ................ } \\
\text { Progressive disease: ............. } \\
\text { Total: ............................ }\end{array}$ \\
\hline Survival & 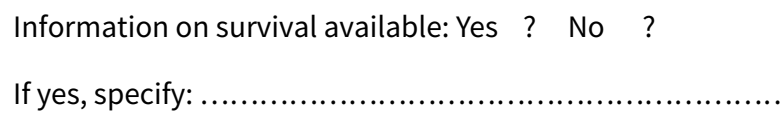 \\
\hline
\end{tabular}




\section{Immunogenicity}

1. Antigen-specific immunogenicity

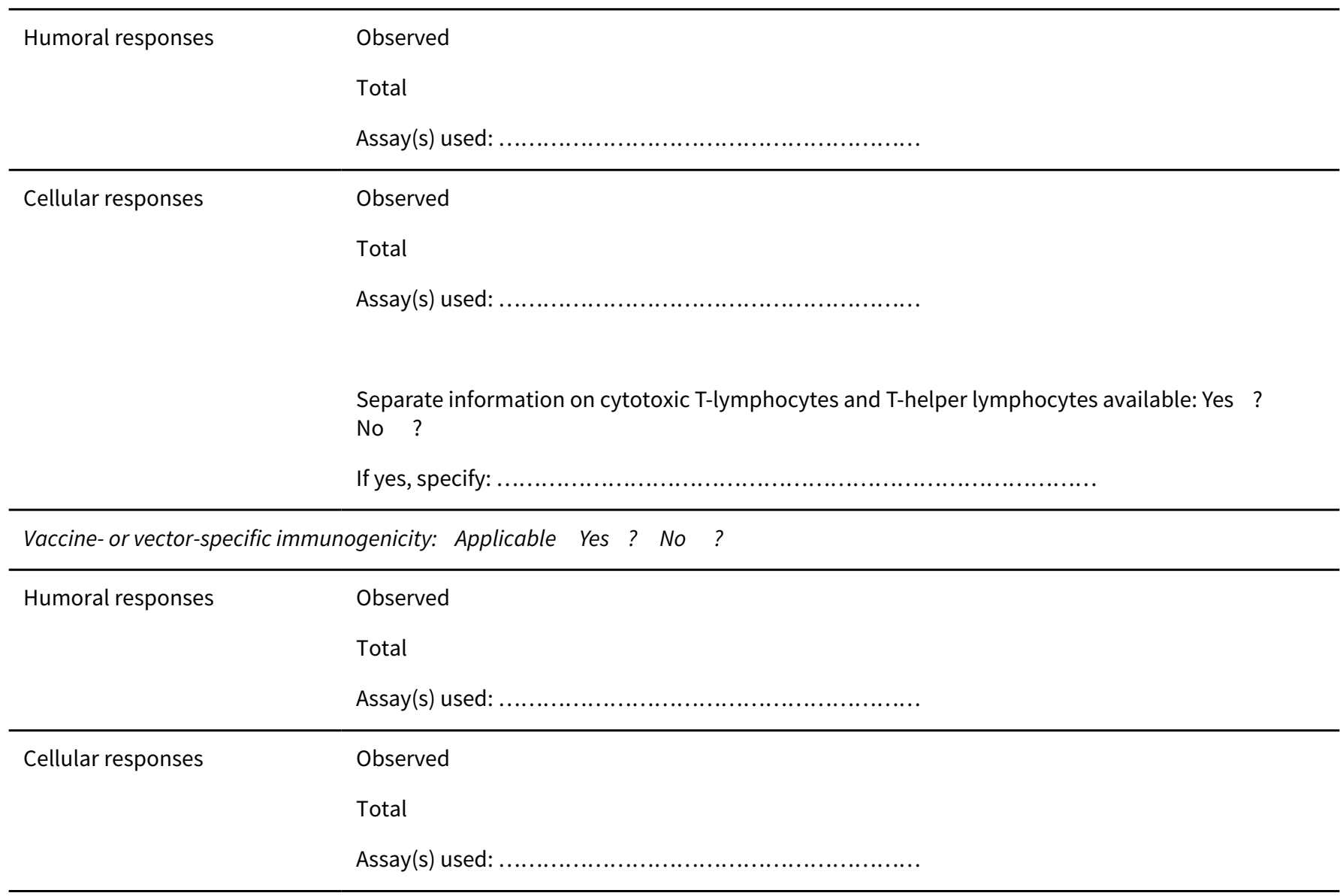

\section{Adverse events}

Type of AEs

Local events (injection site): Yes ? No ?

If yes, specify:

Systemic: Yes ? No ?

If yes:

Autoimmunity: Yes ? No ?

If yes, specify:

Allergic reactions: Yes ? No ?

If yes, specify:

Other:Yes ? No ? 
Other

$\begin{array}{ll}\text { Contact with primary investigators } & \text { Clarify methods ? } \\ \text { Clarify results ? }\end{array}$

Notes

WHAT' S NEW

\begin{tabular}{lll}
\hline Date & Event & Description \\
\hline 13 March 2018 & $\begin{array}{l}\text { New citation required but conclusions } \\
\text { have not changed }\end{array}$ & $\begin{array}{l}\text { Review text updated to reflect additional studies, both included } \\
\text { and excluded. Overall, conclusions unchanged }\end{array}$ \\
\hline 1 August 2017 & New search has been performed & Searches re-run July 2017. New studies included and excluded \\
\hline
\end{tabular}

\section{HISTORY}

Protocol first published: Issue 3, 2008

Review first published: Issue 1, 2010

\begin{tabular}{lll}
\hline Date & Event & Description \\
\hline 8 September 2014 & Amended & Author details amended \\
\hline 31 July 2014 & New search has been performed & $\begin{array}{l}\text { Searches re-run October 2013. New studies included and exclud- } \\
\text { ed }\end{array}$ \\
\hline 10 July 2014 & $\begin{array}{l}\text { New citation required but conclusions } \\
\text { have not changed }\end{array}$ & $\begin{array}{l}\text { Review text updated to reflect additional studies, both included } \\
\text { and excluded. Overall, conclusions unchanged }\end{array}$ \\
\hline
\end{tabular}

\section{CONTRIBUTIONS OF AUTHORS}

NL selected relevant studies, assessed study quality, extracted data, and wrote the review. HWN selected relevant studies, assessed study quality, and extracted data. TD and WH checked all rejected titles and resolved disagreements on study selection and data extraction. HMB and $\mathrm{BC}$ provided statistical and methodological support. KM was supportive of writing the review as an expert in immunology. STP and MDB selected relevant studies, assessed study quality, extracted data, and wrote the second update of this review.

\section{DECLARATIONS OF INTEREST}

Ninke Leffers, Cornelis Melief, Toos Daemen, and Hans Nijman were investigators in two studies included in this review (Leffers 2009a; Vermeij 2012). No potential conflicts of interest are known for the other contributing review authors (WH, BJC, STP, MDB) . 


\section{SOURCES OF SUPPORT}

\section{Internal sources}

- None, Other.

\section{External sources}

- None, Other.

\section{DIFFERENCES BETWEEN PROTOCOLAND REVIEW}

TD was added to the team. For the update of this review, we used the Cochrane 'Risk of bias' tool to assess risk of bias in randomised controlled trials, whereas for the protocol and the previous version of this review, we used the Delphi list. We can report no further relevant differences between protocol and review. For the second update, STP and MB were added to the review author team.

\section{IN DEX TERMS}

\section{Medical Subject Headings (MeSH)}

${ }^{\star}$ Immunotherapy, Active; *Neoplasm Recurrence, Local; CA-125 Antigen; Neoplasms, Glandular and Epithelial; Ovarian Neoplasms

\section{MeSH check words}

Female; Humans 